UNIVERSIDADE DE SÃO PAULO

FACULDADE DE ECONOMIA, ADMINISTRAÇÃO E CONTABILIDADE DEPARTAMENTO DE ADMINISTRAÇÃO PROGRAMA DE PÓS-GRADUAÇÃO EM ADMINISTRAÇÃo

SERVIÇOS AMBIENTAIS: O SURGIMENTO DE ARRANJOS INSTITUCIONAIS

Otília Denise Jesus Ribeiro

Orientador: Prof. Dr. Decio Zylbersztajn

SÃO PAULO 
Prof. Dr. Marco Antonio Zago Reitor da Universidade de São Paulo

Prof. Dr. Adalberto Américo Fischmann Diretor da Faculdade de Economia, Administração e Contabilidade

Prof. Dr. Roberto Sbragia Chefe do Departamento de Administração

Prof. Dr. Moacir de Miranda Oliveira Júnior Coordenador do Programa de Pós-Graduação em Administração 


\section{OTILIA DENISE JESUS RIBEIRO}

SERVIÇOS AMBIENTAIS: O SURGIMENTO DE ARRANJOS INSTITUCIONAIS

Tese apresentada ao Departamento de Administração da Faculdade de Economia, Administração e Contabilidade da Universidade de São Paulo como requisito para a obtenção do título de Doutora em Ciências.

Orientador: Prof. Dr. Decio Zylbersztajn

\section{Versão Corrigida}

(versão original disponível na Faculdade de Economia, Administração e Contabilidade)

\section{SÃO PAULO}


FICHA CATALOGRÁFICA

Elaborada pela Seção de Processamento Técnico do SBD/FEA/USP

\section{Ribeiro, Otília Denise Jesus}

Serviços ambientais: o surgimento de arranjos institucionais /

Otília Denise Jesus Ribeiro. -- São Paulo, 2014.

$226 \mathrm{p}$.

Tese (Doutorado) - Universidade de São Paulo, 2014.

Orientador: Décio Zylbersztajn.

1. Meio ambiente 2. Instituições 3. Pagamentos por serviços ambientais 4. Programas de sustentabilidade 5 . Serviços ambientais I. Universidade de São Paulo. Faculdade de Economia, Administração e Contabilidade. II. Título.

CDD - 363.7 
A você Pedro,

que Deus reserva a nossa felicidade. 
Agradeço ao Curso de Administração da Universidade Federal de Santa Maria (RS) e ao Curso de Administração da Universidade de São Paulo (SP) pelo esforço em promover o DINTER, oportunizando a busca do conhecimento científico e aperfeiçoamento dos seus docentes.

Agradeço a todos os professores do DINTER e a equipe do PENSA, que de maneira incansável me auxiliaram no cumprimento das minhas tarefas de pesquisa, ensino e acompanhamento acadêmico.

Agradeço ao meu orientador, Prof. ${ }^{\circ}$ Decio Zilbersztajan, pela sua orientação e incentivo no desenvolvimento do tema mercado de serviços ambientais, e pelo exemplo de dedicação e desempenho nas atividades de ensino e pesquisa.

Aos responsáveis pelos Projetos de PSA pela disponibilidade e fornecimento das informações que foram utilizadas para o desenvolvimento da pesquisa.

À equipe da empresa Ipiranga Assessoria Contábil Empresarial, pela compreensão das várias ausências ocorridas durante esta etapa.

Aos meus familiares, especialmente e amigos, pelo eterno estímulo recebido, que me permitiu chegar ao final com sucesso.

Àquelas pessoas que, mesmo não fazendo parte do meu convívio diário, não me negaram auxílio quando dele necessitei.

A Deus, pela saúde e coragem de enfrentar e vencer mais esse desafio. 


\section{RESUMO}

Os serviços ambientais são o tema de discussão desta tese, que apresenta análise de casos brasileiros de projetos de pagamentos por serviços ambientais (PSA), dando ênfase a casos de PSA-Água e PSA-Carbono. Os projetos são analisados sob a ótica da Nova Economia Institucional (NEI) com percepção analítica em diversos aspectos, como arranjos institucionais, ambiente institucional, remuneração pelos serviços ambientais, fontes de financiamento, e monitoramento da prestação dos serviços. Da análise dos projetos, identificou-se que todos são de existência recente, por isso os dados disponíveis são escassos. Na maioria dos arranjos institucionais desses projetos, há participação de entidades públicas e privadas, e uma significativa participação de recurso público em seu financiamento. Os projetos apontam os potenciais benefícios à sociedade e ao meio ambiente e suas possíveis limitações. A identificação das restrições na fase inicial do projeto é importante, pois permite que sejam evitadas ou, ao menos, minimizadas, otimizando a alocação dos recursos a ele destinados. Percebe-se que são projetos promissores, razoavelmente estáveis em sua maioria, com potencial de evolução, eficazes e eficientes no tocante ao emprego dos recursos direcionados aos financiamentos. Os critérios analisados nesses projetos podem ser aplicados a outros similares, da mesma forma como as lições depreendidas podem subsidiar a estruturação e a gestão de futuros projetos de PSA. Por fim, é fundamental consignar que o mercado de serviços ambientais só funcionará de forma eficiente com a presença de arranjos institucionais que atendam à demanda específica desses serviços. 


\begin{abstract}
Environmental services are the topic of discussion of this thesis, which presents case studies of Brazilians of payments for environmental services (PES) projects, emphasizing the cases of PSA and PSA-Water-Carbon. The projects are analyzed from the perspective of New Institutional Economics (NIE) with analytical insight into aspects such as institutional arrangements, institutional environment, compensation for environmental services, funding sources, and monitoring of service delivery. Analysis of the projects, it was identified that there are all recent, so the data available are scarce. Institutional arrangements in most of these projects, there is participation of public and private entities, and meaningful participation in public resource funding. The projects show the potential benefits to society and the environment and their possible limitations. The identification of constraints in the initial phase of the project is important as it allows them to be avoided or at least minimized by optimizing the allocation of resources allocated to it. Realize that they are promising projects, mostly fairly stable, with potential for development, effective and efficient with respect to employment of resources directed to financing. The criteria analyzed in these projects can be applied to other similar, just as the inferred lessons can support the structuring and management of future PES projects. Finally, it is essential to establish that the market for environmental services only work efficiently with the presence of institutional arrangements that meet the specific demand for these services.
\end{abstract}




\section{SUMÁRIO}

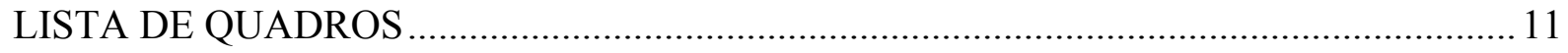

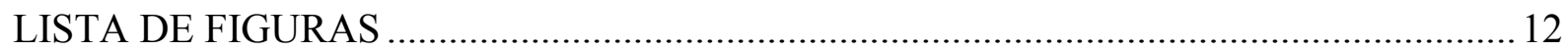

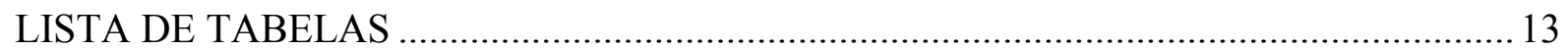

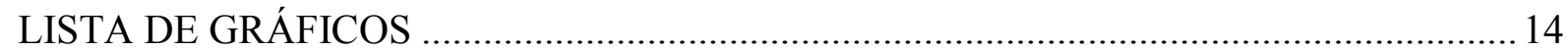

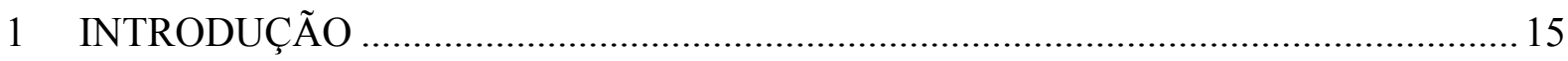

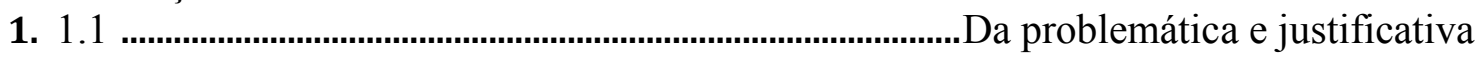

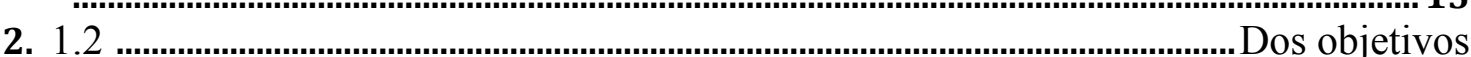

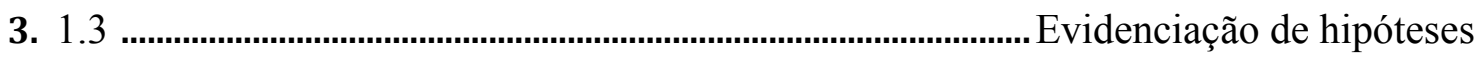

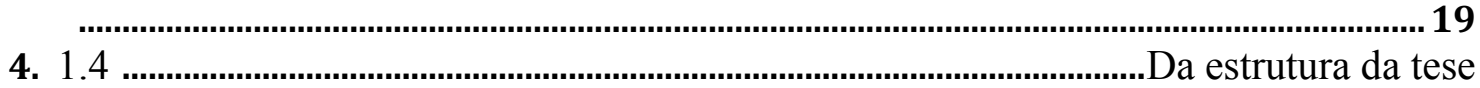

20

2 AS CONCEPÇÕES TEÓRICAS PARA O FUNCIONAMENTO DE MERCADOS

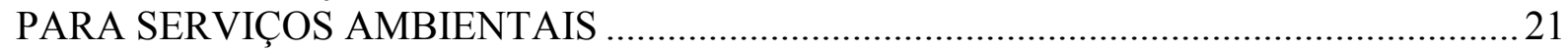

5. 2.1

Gênese do mercado

22

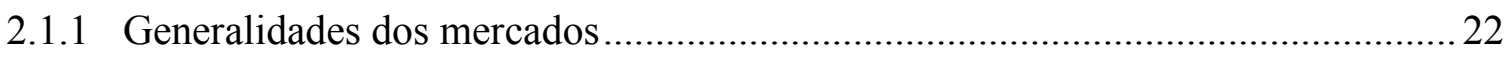

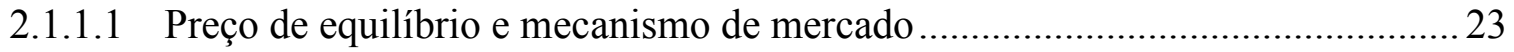

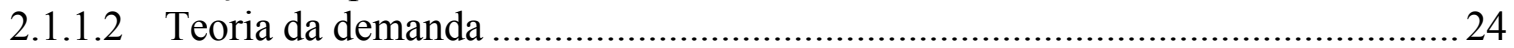

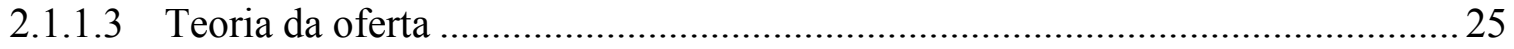

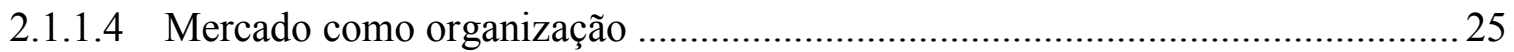

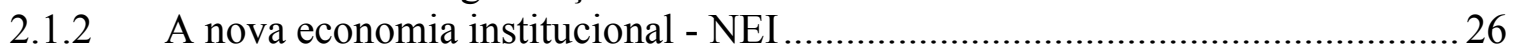

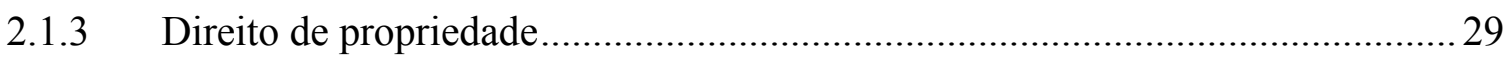

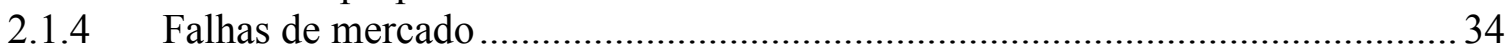

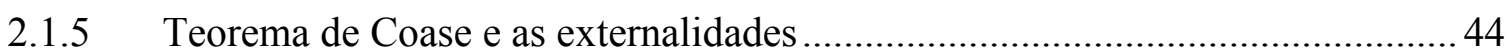

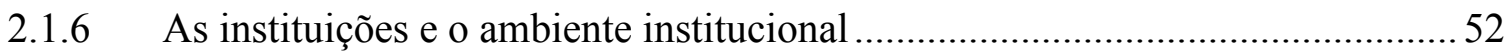

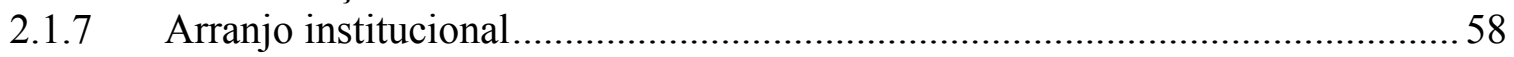

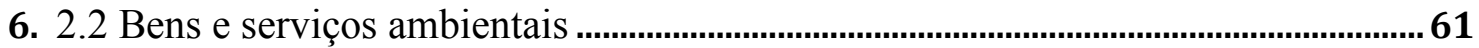

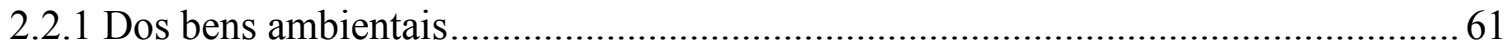

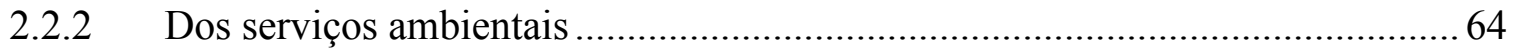

7. 2.3 Pagamento por serviços ambientais e as concepções de mercado de serviços

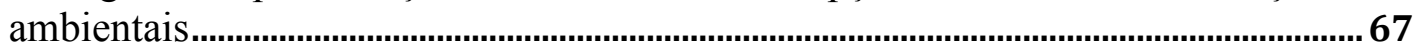

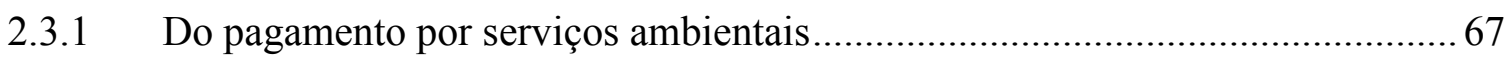

2.3.2 Das concepções de mercado de serviços ambientais ........................................ 82

8. 2.4 ...................................................................ercado de serviços ambientais do carbono

As simetrias e assimetrias dos mercados de serviços ambientais: água e carbono 93

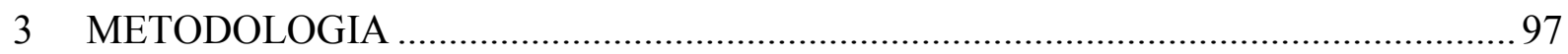

9. 3.1 ............................................................................... Do Protocolo de Estudo de Caso 
10. 3.2 Dos projetos de produção de água e de carbono

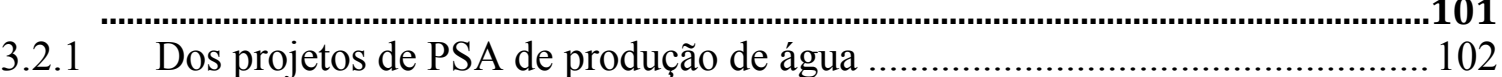

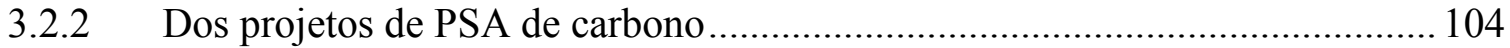

11. 3.3 .......................... Modelo de análise dos projetos de produção de água e de carbono

.106

4 ANÁLISE E DISCUSSÃO DOS PROJETOS DE PAGAMENTOS DE SERVIÇOS

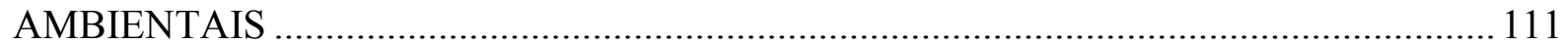

12. 4.1 ....................................................................... Dos Projetos de PSA Produção de Água

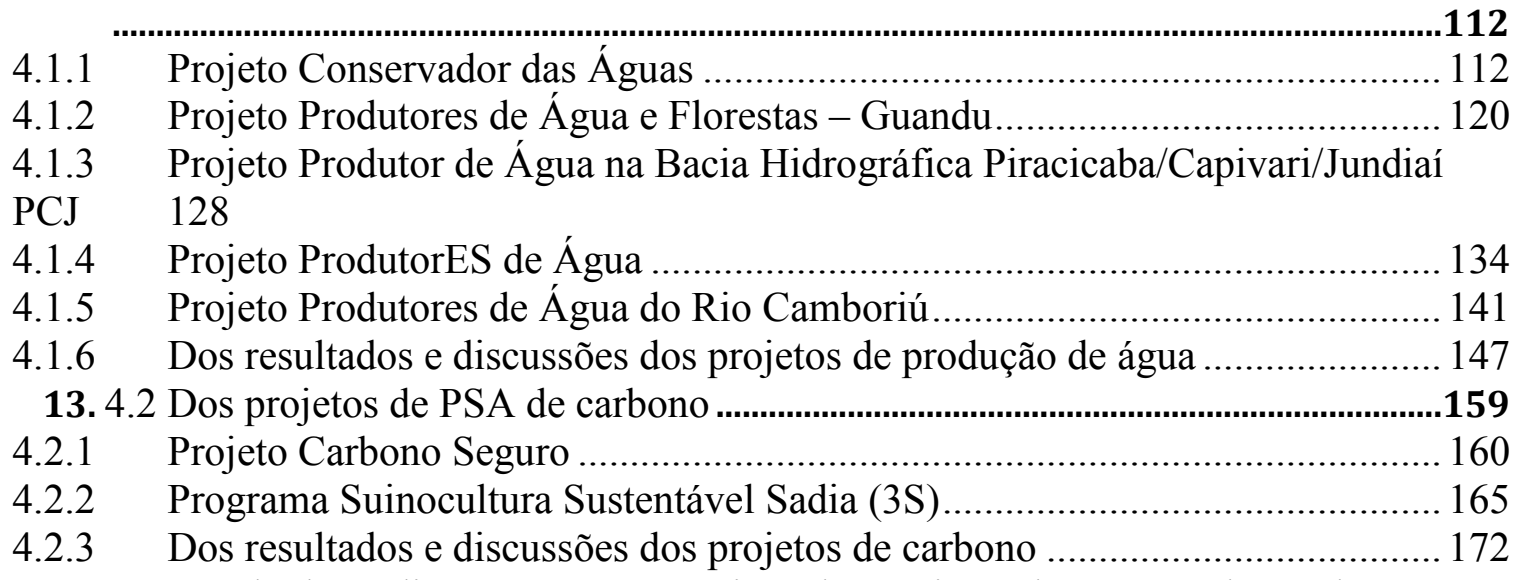

14. 4.3 Resultados e discussões comparativas dos projetos de PSA produção de água e

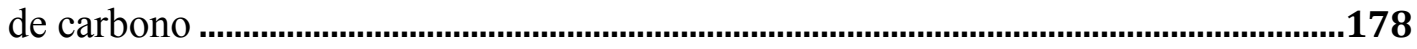

4.3.1 Qual o ambiente institucional visualizado nos projetos? ................................ 180

4.3.2 Nos projetos o direito de propriedade é bem definido? .................................. 181

4.3.3 É possível identificar fatores determinantes de custos de transação? ............... 182

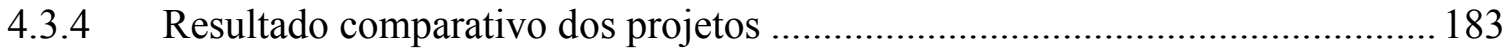

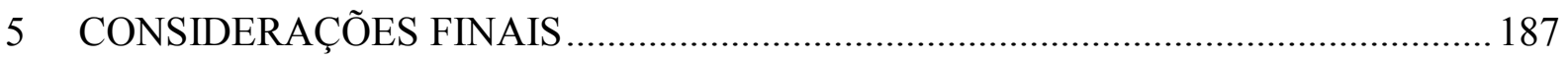

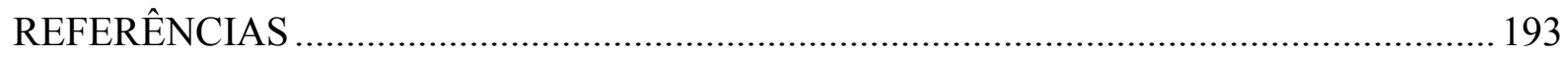

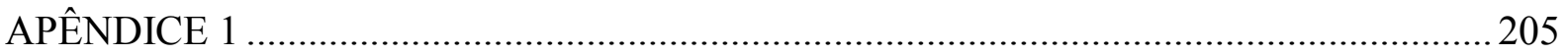

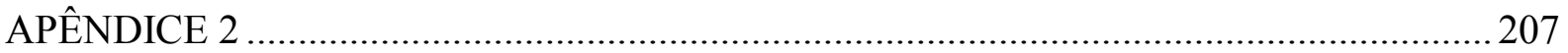

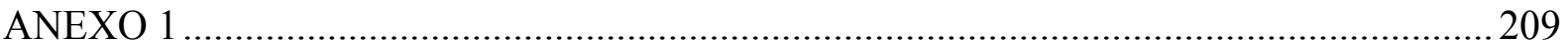

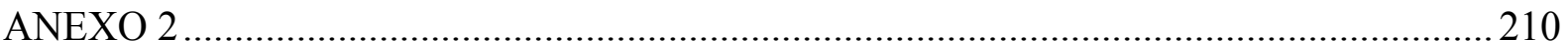

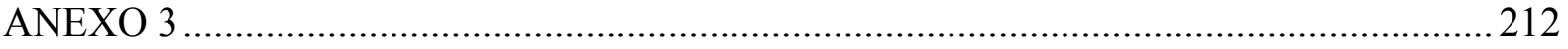

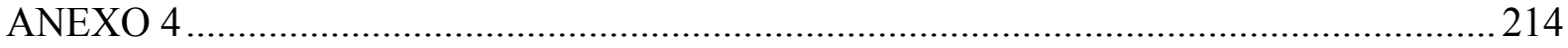




\section{LISTA DE QUADROS}

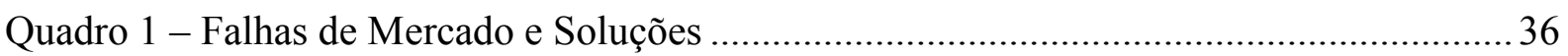

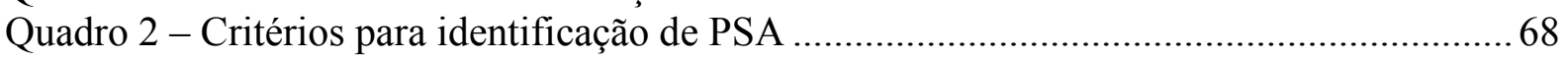

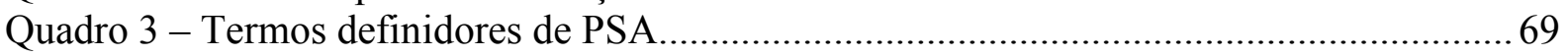

Quadro 4 - Fontes e mecanismos de captação de recursos para PSA ...................................... 77

Quadro 5 - Commodities para serviços ambientais ............................................................. 87

Quadro 6 - Passos para implantação de mercado de PSA ..................................................... 89

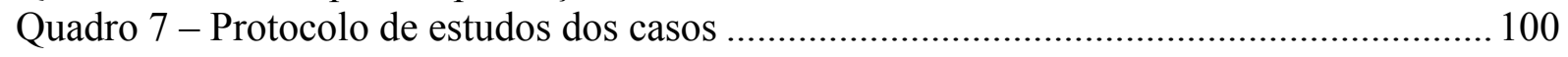

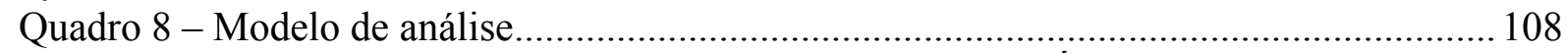

Quadro 9 - Fórmula de cálculo do PSA Projeto ProdutorES de Água.................................. 138

Quadro 10 - Valores de pagamento por serviço ambiental convencionados ......................... 144

Quadro 11 - Resumo dos projetos de produção de água ...................................................... 149

Quadro 12 - Estabilidade institucional dos projetos de produção de água ............................ 158

Quadro 13 - Resumo dos projetos de captura de carbono .................................................. 172

Quadro 14 - Estabilidade institucional dos projetos de captura de carbono.......................... 177

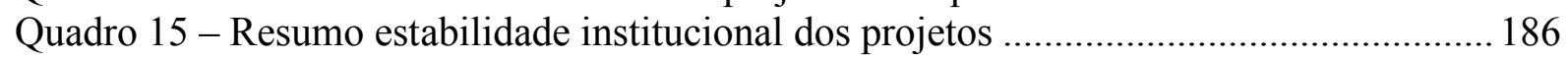




\section{LISTA DE FIGURAS}

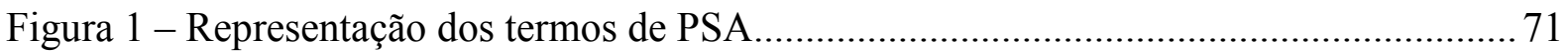

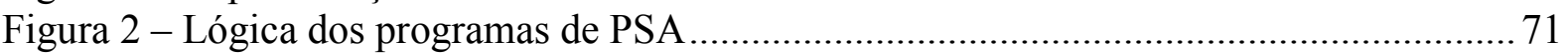

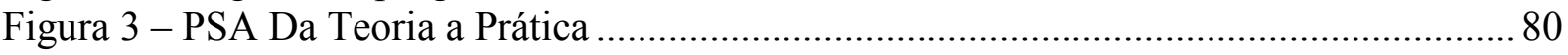

Figura 4 - Localização geográfica dos PSA de produção de água ....................................... 104

Figura 5 - Localização geográfica do PSAs de carbono e Programa 3 S .............................. 106

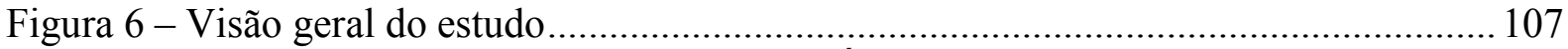

Figura 7 - Funcionamento do Projeto Produtor de Água no PCJ ............................................ 133

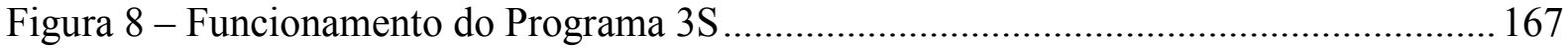

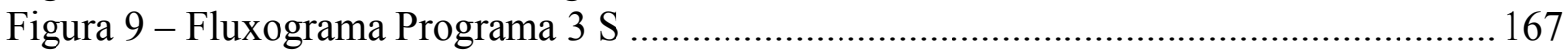

Figura 10 - Etapas de Creditação Programa 3 S ................................................................ 170 


\section{LISTA DE TABELAS}

Tabela 1 - Demonstrativo da evolução da área sob contrato de PSA Conservador das Águas 119

Tabela 2 - Saldo de Indicadores Monitorados até o mês de junho de 2013 Projeto Guandu 127

Tabela 3 - Valores de referência do produtor de água no PCJ (R \$ha/ano)

Tabela 4 - Demonstrativo da evolução da área sob contrato de PSA ProdutorEs de Água ... 138

Tabela 5 - Evolução Projeto Produtores de Agua Rio Camboriú.......................................... 145

Tabela 6 - Evolução projeto Carbono Seguro 164 


\section{LISTA DE GRÁFICOS}

Gráfico 1 - Evolução do Projeto Conservador das Águas ................................................... 119

Gráfico 2 - Evolução do Projeto ProdutorES de Águas .......................................................... 139 


\section{INTRODUÇÃO}

\subsection{Da problemática e justificativa}

As questões relativas às mudanças climáticas começaram a ganhar destaque, principalmente, a partir da década de 1980, quando algumas lideranças, entre as quais agentes cidadãos, governos, academia e investidores, começaram a questionar se as mudanças ambientais colocariam em risco a integridade do planeta. Lideranças e governos perceberam que os recursos demonstravam sinais de esgotamento, sem nenhum tipo de reposição. Estudo pioneiro foi realizado por Rachel em Carson, em The Silent Spring ${ }^{1}$, nos anos 1960, que documentou os efeitos nocivos dos pesticidas e da monocultura no meio ambiente, particularmente em aves. Desde então, as evidências científicas indicam que as atividades humanas de produção desordenadas, nos mais variados setores da economia, decorrentes do consumo de recursos ambientais, são decisivas para o agravamento dessas ameaças. Surgiu um dilema para a sociedade caracterizado pela necessidade de uma agricultura industrial: Como gerar o alimento necessário para a crescente população mundial e manter a biodiversidade do planeta.

A preocupação mundial com o meio ambiente levou os países membros da Organização das Nações Unidas (ONU) a assinar um acordo que estipulou controle sobre as intervenções humanas no clima, em 1999, denominado Protocolo de Quioto ratificado ${ }^{2}$ em fevereiro de 2005. Entre outros impactos advindos dessa mudança institucional, surgiu a possibilidade do surgimento de um mercado de certificados de emissão de créditos de carbono, que passou a ser oficialmente reconhecido com o estabelecimento de condições e regras formalizadas para

\footnotetext{
${ }^{1}$ A BOOK THAT CHANGE THE WORLD. Disponível em:

$<$ http://www.environmentandsociety.org/exhibitions/silent-spring/overview>. Acesso em: 31 mai 2013.

${ }^{2}$ Países que já ratificaram o Protocolo de Quioto: Alemanha, Ucrânia, Reino Unido, Canadá, Itália, Polônia, Espanha, Romênia, Bélgica, Bulgária, Grécia, Dinamarca, Áustria, Suécia, Finlândia, Suíça, Noruega, Nova Zelândia, Lituânia, Irlanda, Luxemburgo, Estônia, Letônia, Eslováquia, Eslovênia. Países que não aderiram ao protocolo: Estados Unidos, Rússia, Austrália, Croácia, Liechtenstein e Mônaco. MINISTERIO DA CIÊNCIA TECNOLOGIA E INOVAÇÃO. Disponível em:

< http://www.mct.gov.br/upd_blob/0210/210584.pdf>. Acesso em: 28 fev. 2013.
} 
as empresas, que pretendem inserir-se nesse novo mercado. O protocolo de Quioto, embora não tendo participação unânime, foi o primeiro sinal mundial de entendimento político quanto à necessidade de mudança do padrão de emissões de gases do efeito estufa.

Nesse sentido, passaram a ser destaque nas discussões internacionais o uso e o comércio internacional dos bens e serviços ambientais, tema da pauta da Rodada de Doha. A Declaração de Doha determinou, em seu parágrafo 31, o mandato de negociador para a liberação do comércio de bens ambientais, negociação realizada no âmbito da Organização Mundial do Comércio (OMC) ${ }^{3}$.

Evoluiu o tema de mercados para serviços ambientais, cujas ações ampliariam os efeitos das intervenções governamentais. Assim, se os mercados de serviços ambientais passarem a ser efetivos, é possível que exerçam pressão para a preservação dos recursos, com a internalização dos custos sociais. Esta pode ser uma das maneiras de controlar o problema, com a redução de custos de transação pela correção das falhas de mercado decorrentes.

Segundo o Programa das Nações Unidas sobre Comércio e Desenvolvimento, embora não exista um acordo sobre a definição de bens e serviços ambientais, eles são distribuídos em uma das seguintes categorias. A primeira inclui equipamentos, materiais e tecnologias destinadas a adequar um problema ambiental particular, tais como o tratamento da água; na segunda, estão os bens industriais de consumo, cujo uso final reduza os impactos negativos sobre o meio ambiente.

Os serviços ambientais podem ser explicados por duas óticas: a primeira, derivada da teoria das externalidades, considera que o mercado é a melhor solução e a "mão invisível" tem pleno funcionamento, quando não há diferença entre os custos privados e sociais de produção dos bens e serviços, e também quando os bens e serviços transacionados são bens privados e não públicos (HEAL, 2000; PERMAN et al, 1996). Ou seja, considera que não existem falhas de mercado. A segunda razão, apontada pela escola econômica para o estado incipiente dos mercados de serviços ambientais, diz respeito à outra forma de abordagem para a internalização das externalidades, promovida por mudanças institucionais que criem incentivos para a produção de bens ambientais por meio da redefinição dos direitos de

\footnotetext{
${ }^{3}$ WORLD TRADE ORGANIZATION. Disponível em: <http://www.wto.org >. Acesso em: 05 abr. 2013.
} 
propriedade, capazes de reduzir os custos transacionais. A ideia de que os agentes possam realizar contratos espontâneos incorporando a dimensão ambiental poderá facilitar a realização de trocas.

A escolha de uma ferramenta para atribuir valores economicamente mensuráveis a bens difusos (ambientais) representa um obstáculo a esse "novo" mercado. Os mercados nem sempre refletem todos os impactos sociais associados ao processo produtivo, o que remete ao conceito de falhas de mercado associadas a imperfeições, distorções, assimetrias informacionais, entre outros. Ou seja, o desafio para criação do mercado é justamente tornar bens e serviços ambientais valoráveis, permitindo que a dimensão ambiental seja incorporada às transações. Isso leva a refletir, que quando bens e serviços ambientais não são plenamente precificados, tal fato decorre de um problema de falha de mercado com a existência de externalidades. Nesse caso, espera-se que as instituições e o ambiente institucional evoluam de modo a permitir a correção das falhas de mercado, criando mecanismos de proteção das gerações futuras.

As soluções tradicionais para as externalidades (internalização das externalidades) são a negociação coasiana (livre mercado) ou a taxação pigouviana (imposição do estado). Semelhante a isso, as soluções tradicionais para o dilema dos comuns são a privatização ou a regulamentação estatal. Afinal o custo da superexploração de recursos de base comum é uma externalidade.

Assim, a intervenção do Estado, por intermédio de tributos seletivos, ou imposições legais com base em agências reguladoras, proporciona as condições de oferta dos bens e serviços ambientais. No caso da imposição de tributos, o poluidor paga a conta decorrente do dano causado. Contrariamente, não havendo a intervenção do Estado, a sociedade irá sofrer o encargo financeiro decorrente, e ficará sujeita a poluição ou/e escassez do recurso. Outros mecanismos de natureza privada podem surgir, a exemplo da certificação ambiental, no sentido de incentivar a produção sob condições sustentáveis. Exemplo disso é FSC Brasil Forest Stewardship Council, uma organização independente, não governamental, sem fins 
lucrativos, criada para promover o manejo florestal responsável ao redor do mundo, por meio da certificação florestal $^{4}$.

Dessa forma o foco do presente estudo são as transações que podem ser realizadas por meio de mercado ou contratos complexos, além da intervenção governamental.

As inciativas dos projetos de pagamento por serviços ambientais, objeto desse estudo, bem como a sua categorização e potencial de permanência, deverão ser avaliadas quanto aos arranjos institucionais criados para cada projeto, especificamente quanto a sua sustentabilidade no longo prazo no que se refere à origem dos recursos; quanto à espontaneidade das ações dos agentes (ofertantes e demandantes), quanto ao papel das instituições envolvidas nos projetos, bem como o ambiente institucional onde essas incitativas estão inseridas.

Nesse contexto, o problema da presente pesquisa é identificar quais os pressupostos e condicionantes institucionais para o surgimento de mercados de serviços ambientais?

\subsection{Dos objetivos}

Para responder adequadamente ao problema da pesquisa - Quais os pressupostos e condicionantes institucionais para o surgimento de mercados de serviços ambientais? -, o objetivo geral do presente estudo é discutir a evolução do significado de serviços ambientais e sua importância para a sociedade, e apresentar evidências que revelem as tentativas em curso de criar incentivos para o surgimento de mercados de serviços ambientais. Especificamente pretende-se:

\footnotetext{
${ }^{4}$ O FSC foi criado em 1993, como resposta às preocupações sobre o desmatamento global e o destino das florestas mundiais. A missão do Conselho Brasileiro de Manejo Florestal é difundir e facilitar o bom manejo das florestas brasileiras conforme princípios e critérios que conciliam as salvaguardas ecológicas com os benefícios sociais e a viabilidade econômica. O conceito da certificação surgiu, então, como uma forma de controle das práticas produtivas florestais, por meio da valorização, no mercado, dos produtos originados de manejo responsável das florestas. Um grupo formado por empresas e organizações sociais e ambientais do mundo todo iniciou as negociações para a criação de uma entidade independente que estabelecesse princípios universais para garantir o bom manejo florestal. Desde então, o FSC tornou-se o sistema de certificação florestal de maior credibilidade internacional e o único que incorpora de forma igualitária os interesses de grupos sociais, ambientais e econômicos. FOREST STEWARDSHIP COUNCIL BRASIL. Disponível em $<$ http://br.fsc.org/misso.176.htm>. Acesso em: 18 mai. 2014.
} 
a) analisar as condicionantes institucionais necessárias para o surgimento de mercados em geral e de serviços ambientais em particular;

b) identificar os projetos de PSA de Água e de Carbono existentes, vistos como arranjos institucionais ${ }^{5}$;

c) analisar de forma comparativa a estrutura e o mecanismo de funcionamento dos projetos de PSA de Água e de Carbono;

d) analisar de forma comparativa os aspectos de estabilidade institucional existentes nos de PSA de Água e de Carbono;

e) analisar a evolução do mercado de serviços ambientais visto sob a ótica econômica.

\subsection{Evidenciação de hipóteses}

A hipótese que norteou a presente pesquisa foi de que o surgimento de mercados de serviços ambientais depende de instituições que controlem os custos de transação existentes, caso contrário, os mercados não operarão de forma espontânea.

Uma das condições de criação e evolução do mercado de serviço ambiental é a possibilidade de demandantes e ofertantes poderem negociar nesse mercado, o que vai ocorrer somente se os custos de transação forem baixos o suficiente para que as partes possam transacionar livremente nesse mercado. Assim, na presença de custos de transação, as negociações de serviços ambientais dependerão de projetos de PSA com programas específicos e pontuais, cuja permanência dependerá de iniciativas individuais de agentes locais, o que dificulta a aplicabilidade em outros locais/regiões que ainda sejam incipientes nessas iniciativas.

Portanto, evidenciam-se a hipótese em avaliar se os projetos de PSA de Água e de Carbono continuariam a ter sua implantação e seu desenvolvimento, em nível local, estabelecidos por uma relação contratual entre os compradores e os vendedores, como atualmente acontece na maioria dos projetos de pagamentos por serviços ambientais existentes, com a presença forte do Estado. Em outras palavras, não surgem transações espontâneas.

\footnotetext{
${ }^{5} \mathrm{O}$ arranjo institucional é aquele entre unidades econômicas que administram o meio pelo qual tais unidades podem cooperar (...) ou podem fornecer um mecanismo que pode proporcionar uma mudança nas leis ou no direito de propriedade. (WILLIAMSON, 1996, p. 103)
} 


\subsection{Da estrutura da tese}

O presente estudo está estruturado em quatro capítulos, como segue. No segundo capítulo, apresentar-se-á o suporte teórico com as contribuições científicas existentes acerca do tema de pesquisa, os pressupostos para o surgimento de mercados de serviços ambientais, e, pelo grau de relevância, foram aí incluídos os conteúdos relativos ao desenvolvimento de mercados e suas generalidades; a nova economia institucional, o direito de propriedade, as falhas de mercado, o teorema de Coase e as externalidades, as instituições, o ambiente institucional e os arranjos institucionais, e, por fim, a revisão de literatura sobre serviços ambientais e pagamento por serviços ambientais.

No terceiro, descrever-se-á a metodologia utilizada ao longo do desenvolvimento da pesquisa, com ênfase ao estudo de caso, apresentando-se o protocolo de estudos de casos bem como sua tipologia. No quarto capítulo, contemplar-se-á a análise empírica comparativa dos projetos de pagamento por serviços ambientais de água e de carbono, estudados sob o ponto de vista da teoria da nova economia institucional, abordando a definição do direito de propriedade, o ambiente institucional, os arranjos institucionais, as externalidades geradas e os custos de transação envolvidos e sua origem, bem como as fontes de financiamentos. Por fim, apresentam-se as conclusões do trabalho de pesquisa. 


\section{AS CONCEPÇÕES TEÓRICAS PARA O FUNCIONAMENTO DE MERCADOS PARA SERVIÇOS AMBIENTAIS}

Neste capítulo, o objetivo é apresentar as contribuições científicas existentes acerca do tema de pesquisa serviços ambientais e os incentivos para criação de mercados, com o intuito de ordenar as informações e os conhecimentos prévios a respeito do problema central para o qual se procura resposta. As contribuições formarão o suporte teórico para fundamentar a resposta aos objetivos de pesquisa, e, pelo grau de relevância, incluirão os conteúdos relativos ao desenvolvimento de mercados e suas generalidades, enfatizando a nova economia institucional; o direito de propriedade; as falhas de mercado; o teorema de Coase e as externalidades; as instituições, o ambiente institucional e os arranjos institucionais. Por fim, far-se-á a revisão de literatura sobre serviços ambientais e pagamento por serviços ambientais.

Como se formam os mercados? Quais as vantagens da troca? Como se formam os preços? Estas são questões centrais na teoria econômica, que ganham nova roupagem quando se focaliza o surgimento de novos mercados em geral e dos mercados de serviços ambientais em particular. A formação e o desenvolvimento de um mercado pressupõem a existência de um excedente econômico, compartilhado entre produtores e compradores. Ou seja, um fundamento da teoria econômica é de que a troca gera valor para a sociedade. Tal fato é relevante para a moderna economia das organizações e tem reflexo na nova economia institucional.

Mercado, na concepção de Parkin (2009, p. 40), "é qualquer estrutura que permita que compradores e vendedores obtenham informações e façam negócios uns com outros", considerado o local real ou virtual em que se encontram os produtores e consumidores para vender e comprar seus produtos, sendo o processo a partir do qual são definidos os preços. $\mathrm{O}$ mercado compõe-se de instituições que facilitam as trocas entre os agentes econômicos, reduzindo os custos de busca, informação, facilitam a definição do valor dos bens ou dos serviços que são alvo de troca. Uma vez que o mercado gera informações relevantes, pode também influir nos mecanismos de garantia do cumprimento dos contratos, por meio de salvaguardas reputacionais. 
Afirma Buonocore (2002) que o conceito de mercado não se restringe ao de destinatário do produto de atividade empresarial, mas também como critério que qualifica o instituto empresa. $\mathrm{O}$ autor explica que mercado corresponde ao âmbito natural de atuação da empresa, no qual se concentram vários interesses que, em conjunto, impulsionam a atividade negocial. Sztajn (2004, p. 34) destaca que "na medida em que se entenda mercado como instituição que vise criar incentivos, reduzir incerteza, facilitar operações entre pessoas, fica clara a ideia de que mercados aumentam a prosperidade e, portanto, o bem-estar geral”.

Dessa maneira, o estudo considera o papel central dos arranjos institucionais, como fonte de informações para subsidiar os incentivos para a produção, a troca e a precificação de serviços ambientais.

\subsection{Gênese do mercado}

\subsubsection{Generalidades dos mercados}

A compreensão de alguns aspectos na área da microeconomia é fator relevante para verificar como ocorre o desenvolvimento dos mercados. E, ainda, porque os seus subsídios, primeiro auxiliarão a identificar, quais os atores envolvidos e como são realizadas as operações negociais; e, segundo, apresentam informações necessárias para revelar a interação e o desenvolvimento com os diversos setores da economia.

A teoria de preços, segundo Vasconcelos (2011, p. 109), é uma parte da microeconomia. O autor a descreve "como sendo responsável pela análise de preços no mercado, ou seja, como a empresa e o consumidor interagem e decidem qual o preço e a quantidade de determinado bem ou serviço em mercados específicos”. Aduz o autor que a microeconomia não deve ser confundida com economia de empresas, pois enquanto esta enfoca uma empresa específica, prevalecendo uma visão contábil-financeira na formação do preço de venda de seu produto, com base principalmente nos custos de produção; aquela estuda o funcionamento da oferta e da demanda na formação do preço no mercado, isto é o preço obtido pela interação do conjunto de consumidores com o conjunto de empresas que fabrica um dado bem ou serviço. 
A economia neoclássica está assentada em princípios basilares econômicos, em que os recursos são escassos e que, por isso, qualquer sistema econômico que tenha um grupo de pessoas enfrenta trade-offs, ou seja, existem escolhas a serem feitas seja no consumo, seja na produção. Para o exame necessário, os economistas usam o modelo conhecido como fronteira das possibilidades de produção. O termo trade-offs aqui é utilizado como sendo o processo de escolha e suas limitações. Exemplifica-se o problema do tratamento do risco ambiental e a questão do trade-offs é uma escolha entre crescimento econômico e preservação do meio ambiente. Cada sociedade pautará sua posição, considerando suas preferências, os recursos disponíveis e suas instituições.

Assim, a teoria neoclássica tem como principal função do mercado a determinação dos preços. Estes, por sua vez, são as informações que os agentes econômicos utilizam para tomar suas decisões de consumo e produção, entre outras.

\subsubsection{Preço de equilíbrio e mecanismo de mercado}

Há uma tendência lógica no mercado segundo a qual fornecedores e consumidores interagem de maneira a evitar que haja excedente na quantidade fornecida ou escassez na quantidade consumida. Essa interação leva ao ponto de equilíbrio que seria o preço marcado pela interseção entre a curva de oferta e a curva de demanda. O equilíbrio ideal não deveria necessitar da intervenção do Estado, uma vez que qualquer interferência distorceria as condições normais do mercado. Ou seja, quando o mercado funciona sem ruídos, a alocação dos recursos está garantida e o equilíbrio é socialmente ótimo. Hayek (1944) denomina essa situação como "a maravilha do funcionamento do sistema de preços".

É nesse contexto, que se insere a explicação de Adam Smith sobre a metáfora, "a mão invisível" para ilustrar como oferta e procura se equilibram dentro do funcionamento "natural" do mercado. Em síntese, o argumento é que, na busca pessoal pela obtenção do maior lucro possível no trabalho de cada um, os indivíduos tentam ser mais eficientes e, assim, acabam beneficiando toda a sociedade. Economistas liberais ou clássicos acreditam que a interação entre indivíduos racionais, que buscam ser mais eficientes para aumentar seus lucros, acarreta uma dinâmica geral no mercado, que gera resultados econômicos melhores do 
que os obtidos quando o Estado se propõe a substituir essa racionalidade de mercado por uma racionalidade social politicamente construída, que é implementada por meio do direito (FRANK; BERNANKE, 2012).

A presença de imperfeições, que será discutida mais adiante, muda esse quadro, sugerindo que os custos de transação afetam o funcionamento dos mercados, e até mesmo sua existência.

\subsubsection{Teoria da demanda}

Inicialmente, o comportamento do mercado é compreendido por uma sintética revisão da maneira pela qual as curvas da oferta e da demanda são utilizadas para descrever o mecanismo de formação dos preços. A demanda é o desejo de adquirir, a aspiração, e não sua realização, sendo considerada como o fluxo por unidade de tempo, pois ela se expressa por certa quantidade em dado período.

Quando se estuda a demanda, a pergunta importante a fazer é: Quais fatores ou variáveis influenciam a demanda? Montoro Filho (2011) responde a essa pergunta dizendo que a teoria da demanda é derivada de hipóteses sobre a escolha do consumidor entre diversos bens que seu orçamento lhe permite adquirir, e apresenta quatro determinantes: o preço do bem; preços de outros bens; renda do consumidor; e gosto ou preferência do indivíduo. O autor esclarece que o entendimento da influência em cada determinante na demanda é necessário na análise de cada variável separadamente, considerando-se a hipótese de que tudo o mais permaneça constante (aplicando a cláusula ceteris paribus).

Portanto, a demanda por um produto depende de seu preço, e também de outras variáveis, tais como nível de renda do consumidor e preço de outros produtos, ou seja, trabalhar com todos esses condicionantes ao mesmo tempo, em uma análise de equilíbrio geral, exige um instrumental estatístico complexo. Para isso, a microeconomia lança mão do artifício de ceteris paribus - mantidas as demais variáveis constantes e trabalha com um conjunto restrito de variáveis. 


\subsubsection{Teoria da oferta}

Da mesma forma que a demanda, existem diversos condicionantes que interferem na produção e posterior oferta dos produtos. Entre os mais significativos, estão o preço dos atores de produção, a tecnologia de produção e o preço dos demais bens produzidos, sejam os concorrentes, sejam os substitutos, sejam os complementares. A influência em cada determinante na oferta é necessária a análise de cada variável separadamente, considerando a hipótese de que tudo o mais permaneça constante, ou seja aplicando a cláusula ceteris paribus.

Os preços na economia de mercado são determinados tanto pela oferta quanto pela demanda, o que sugere conceitualmente que as necessidades e as potencialidades da economia resultam em um preço de equilíbrio. A curva da oferta é crescente e a da demanda é decrescente, e exatamente em seu ponto de intersecção a quantidade que os consumidores desejam comprar é exatamente igual à quantidade que os produtores desejam vender, representando a coincidência e o equilíbrio dos desejos. Por outro lado, se o preço aumentar desse ponto de equilíbrio, a quantidade que os ofertantes desejam vender é maior que aquela que os consumidores desejam comprar, ou seja, existe um excesso de oferta, concluindo-se então que maior o preço, maior será o excesso de oferta. De outra parte, para preço inferior do ponto de equilíbrio, surgirá o excesso de demanda, ou seja, quanto menor o preço, maior o excesso de demanda.

Portanto, o mercado pode ser visto como uma instituição que permite que demanda e oferta, consumidores e firmas, compradores e vendedores se encontrem. Para Pinheiro e Saddi (2005), na teoria neoclássica, a principal função do mercado é determinar os preços, que, por sua vez, são a principal informação com que os agentes econômicos trabalham para tomar suas decisões de consumo e produção. No mercado, o preço é definido como de equilíbrio, quando leva às decisões individuais de consumo e produção que, somando todos os consumidores e todas as firmas, geram igualdade entre a demanda e a oferta agregada.

\subsubsection{Mercado como organização}


O mercado pode ser visto como uma estrutura de governança, um arranjo institucional, e não pode ficar restrito à função de determinação dos preços, informação de grande importância aos agentes econômicos para decisão. Para Demsetz (1997), o mercado consiste em uma organização cuja função é orientada à satisfação do povo. Essa forma de organização não é intencional, mas espontânea, por conta das extremas descentralização e interdependência que lhe são características. Isso não significa que a organização do mercado se situa fora da história, alheia às influências culturais. Como uma forma de organização social, o mercado é condicionado pelas instituições, formais e informais, de determinada sociedade.

Nesse sentido, o mercado desempenha a função de satisfazer necessidades sociais dentro dos limites impostos pelo contexto institucional; vale dizer, as trocas realizadas em mercados são aquelas possibilitadas pelas instituições, as quais pressionam estas a se adaptarem.

Assim, de acordo com os pressupostos da economia neoclássica, para um agente econômico decidir onde pretende adquirir um bem, bastaria a ele verificar qual a oferta desse bem, de modo a identificar qual o menor preço. Para Coase (1937), essa assunção é irrealistica, pois a busca de informação sobre quem são os fornecedores e quais os preços desse bem não é isenta de custos. Pelo contrário, procurar informações por um bem envolve a utilização de recursos, por exemplo, o tempo de trabalho de um funcionário e a utilização de recursos tecnológicos.

\subsubsection{A nova economia institucional - NEI}

Essa linha teórica está concentrada, principalmente, nas premissas de que as instituições são importantes para análise econômica, e que elas afetam o desempenho econômico de maneira sistemática e preditiva.

Coase (1937) deu início ao estudo das condições sob as quais os custos de transação deixam de ser desprezíveis e passam a ser um elemento importante nas decisões dos agentes econômicos, contribuindo para determinar a forma pela qual são alocados os recursos na economia. A análise dessas condições, assim como as consequências dos custos de transação para a eficiência do sistema econômico, constitui o objeto dessa teoria. Neste trabalho, foi 
possível entender que as transações comerciais de troca são reguladas não exclusivamente pelo sistema de preço, mas também pelos contratos. Ou seja, a operação dos mercados acontece em condições de custos de transação positivos, levando ao surgimento de outros arranjos institucionais, como contratos, formas de produção verticalmente integradas e, no limite, intervenções do Estado.

Quando há concorrência perfeita, as interações entre empresas e consumidores no mercado são suficientes para gerar equilíbrio em que o bem-estar é maximizado. Ninguém discorda de que as condições para a existência de concorrência perfeita são muito fortes e dificilmente encontradas no sistema de mercado. Entretanto, o teorema de Coase (1937) foi expresso tendo como referencial que, na concorrência perfeita, os custos sociais e privados serão iguais. A formulação mais conhecida do teorema é que, numa situação de custos de transação zero, a alocação final dos direitos de propriedade, obtida por meio da barganha entre as partes, será sempre eficiente, não importando sua alocação original.

Nesse sentido, os custos de transação são um conceito fundamental na teoria institucional e na análise da economia e são definidos por Williamson (1985) como os custos para estabelecer, manter e utilizar os direitos de propriedades, ou seja, para transacionar, como custos de elaboração de contratos, monitoramento e imposição de contratos, de acesso à informação.

Coase (1937) demonstrou em sua obra que tudo o que é feito em uma empresa pode ser efetuado por intermédio do mercado com um conjunto ou feixe de contratos adequadamente desenhados; o que leva a produção a organizar-se de uma ou outra forma é, em larga medida, o custo de transação inerente a cada opção. Os custos de transação, segundo o autor, são aqueles que os agentes enfrentam toda vez que recorrem ao mercado, compreendendo os custos de negociar, redigir e garantir o cumprimento de um contrato, nesse caso a unidade básica de análise.

Williamson (1985) esclarece que os custos de transação tornam-se importantes, quando se alteram três suposições usuais da teoria neoclássica. A primeira é que as pessoas têm racionalidade ilimitada ${ }^{6}$, isto é, são capazes de absorver e processar, de forma ótima, toda a

\footnotetext{
${ }^{6}$ A teoria do custo de transação trabalha com o conceito de racionalidade limitada, uma forma de racionalidade imperfeita que assume que as pessoas buscam maximizar sua utilidade, mas estão sujeitas a restrições cognitivas que podem transformar a capacidade de processamento mental no fator mais importante a ser economizado.
} 
informação disponível. A segunda, o comportamento das pessoas é baseado na busca do interesse próprio ${ }^{7}$, mas respeitando a regra do jogo. A terceira, o capital pode ser transferido de uma atividade para outra com custo zero. ${ }^{8}$

A noção de custo de transação zero pressupõe uma situação de informação perfeita e acessível sem custos para as partes; um direito de propriedade completo e bem definido, que não permita apropriações por terceiros e corresponda a toda a extensão do bem; racionalidade ilimitada, isto é, as pessoas são capazes de absorver e processar toda a informação disponível; e a concorrência perfeita.

Portanto, a teoria dos custos de transação trazida por Williamson (1985) suspende a hipótese de simetria de informações e elabora um conjunto de pressupostos e características das transações que tornam os custos de transação significativos: racionalidade limitada, complexidade, incerteza, oportunismo e especificidade de ativos.

Em relação aos serviços ambientais, os custos de transação são definidos como aqueles envolvidos com a realização de atividades que tendem a ser necessárias para viabilizar a concretização de determinada transação. Explica-se, primeiro, a atividade de busca pela informação sobre a regra de distribuição de preços e a qualidade dos serviços ambientais; segundo, a atividade de negociação que será necessária para determinar as verdadeiras intenções e os limites de compradores e vendedores dos serviços ambientais; e, terceiro, a realização e a formalização de contratos, inclusive o registro nos órgãos reguladores competentes, bem como a correta aplicação do referido contrato, com a cobrança de indenização por prejuízos às partes faltantes ou que não estiverem seguindo suas obrigações contratuais e os esforços para recuperar o controle de direito de propriedade que tenha sido parcial ou totalmente expropriado.

Assim, considerando o interesse da presente pesquisa, os custos de transação são os custos totais associados a uma transação e incluem os custos relacionados à implantação e à manutenção de um esquema de PSA, como os custos de informação, procura, negociação e

\footnotetext{
${ }^{7} \mathrm{Na}$ teoria do custo de transação, o comportamento humano é marcado pelo oportunismo, definido como uma prática desonesta, incluindo-se aí mentir, trapacear e roubar.

${ }^{8}$ A teoria do custo de transação, pelo contrário, assume que nem sempre isso é possível, sendo frequente que determinado ativo muito produtivo em uma atividade (transação) seja menos em outra. O tamanho da perda dependerá de como foi criado o ativo em que o capital resta incorporado.
} 
certificação anteriores ao início do projeto, e também os custos de negociação entre vendedores e compradores, monitoramento, controle, fiscalização e validação dos serviços providos durante o período de execução do projeto (CACHO et al 2005).

Para Wunder et al (2009), o valor dos serviços ambientais disponíveis deve exceder os custos de oportunidade de provedores (vendedores e produtores) de serviços ambientais, isso implica dizer que esse valor deve contemplar o resultado, que alcançaria pela exploração de uma atividade produtiva de uso do solo acrescido dos custos de transação envolvidos. O autor reforça, ainda, que é possível ocorrerem casos em que os lucros gerados sobre determinados usos da terra podem ser demasiadamente altos para competir com a disposição dos usuários de pagar pelos serviços afetados por esses usos, exemplo disso é o cultivo da soja nas propriedades. E, ainda, os custos de transação para implantar um programa de PSA podem ser proibitivos, não permitindo nessas situações que os esquemas de PSA sejam os instrumentos de conservação adequados.

Portanto, no caso do mercado de serviços ambientais, identificam-se como custos de transação as atividades de busca: pela informação sobre as regras de distribuição dos preços e qualidade dos serviços; pela identificação de potenciais compradores e vendedores, assim como, de informação relevante sobre o comportamento dos agentes e as circunstâncias em que operam; pela atividade de negociação que será necessária para determinar as verdadeiras intenções e limites de compradores e vendedores; pela realização e formalização de contratos; pelo monitoramento dos parceiros contratuais com intuito de verificar se aquelas formas contratuais estão sendo devidamente cumpridas; pela proteção do direito de propriedade contra a expropriação por particulares ou pelo próprio setor público; e, ainda, pela correta aplicação do contrato. Ou seja, existem elementos que dão suporte à hipótese de que os custos de transação impedem que os mercados de serviços ambientais surjam espontaneamente.

\subsubsection{Direito de propriedade}

O direito de propriedade, em regra, é entendido como o direito ou o poder de consumir, obter rendimentos, ou mesmo alienar um ativo. Ou seja, o direito de propriedade sobre uma organização é aquele em que há possibilidade de usar os benefícios decorrentes da atividade 
operacional e obter, ao final do processo produtivo, a apropriação devida sobre o resíduo ou resultado positivo. Inclui-se, também, a transação desse direito no mercado, convertendo o ativo produtivo em unidades monetárias.

Mueller (2007) aduz que, na economia neoclássica, adota-se o pressuposto de que os direitos de propriedades são perfeitamente definidos e completamente seguros, e não se incorre em nenhum custo na obtenção e na defesa desses direitos, que são sempre respeitados. Os direitos de propriedade, em Demsetz (1967), são um instrumento da sociedade. Sua importância está no fato de possibilitar ao homem criar expectativas, fundamentadas em leis, hábitos e costumes da sociedade, ao constituir seus relacionamentos com os outros.

Quando se trata de bens e serviços ambientais, os direitos de propriedade terão seu ponto inicial estabelecido pelo ambiente institucional formal externo decorrente de atos normativos de órgãos reguladores quando se trata das permissões para o uso e exploração desses ativos.

Coase (1960) argumenta que, se os direitos de propriedade forem estabelecidos de forma adequada, os mercados podem cuidar das externalidades sem que o governo tenha de intervir diretamente, a analogia vale para os bens ambientais.

O direito de propriedade, na concepção econômica desenvolvida por Alchian $(1965,1987)$ e Cheung (1969), é essencialmente a capacidade de desfrutar de um pedaço de propriedade. Os autores enfatizam que o direito de propriedade não se limita à dimensão legal, pois, além dela, inclui a questão das normas sociais, ou seja, as forças dos costumes sociais e do desejo de integração também condicionam o uso dos recursos ambientais e, portanto, circunscrevem os direitos de propriedade.

Eggertsson (1990) distingue três categorias de direitos de propriedade. O primeiro é definido como os direitos de uso de um bem, incluindo o direito de transformar fisicamente e até destruí-lo, é denominado direitos do usuário. É importante considerar que restrições de direitos que diminuem o conjunto de usos permitidos vão diminuir o valor econômico do bem se usos com importante valor são excluídos. O segundo trata-se do direito de obter renda sobre o ativo e sobre contrato com outros indivíduos. O terceiro, por sua vez, refere-se ao direito de transferir permanentemente a outras partes os direitos de propriedade sobre o bem, ou seja, o direito de alienar ou vender um bem. 
A partir dessa definição, depreende-se que direitos de propriedade são quase sempre restringidos ou particionados de alguma forma, por exemplo, por meio de regulamentos que regem temporadas de pesca e equipamentos de pesca ou a comercialização de medicamentos (EGGERTSSON, 1990).

Zylbersztajn (1995) considera a teoria dos direitos de propriedade a partir de Demsetz (1967), segundo o qual os direitos de propriedade sobre determinado bem, em sua expressiva maioria, não permitem seu uso ilimitado e incondicional. Os ativos ambientais por sua característica implicariam a aplicação das três formas distintas de direito de propriedade: o direito de uso, o direito de usufruto e o direito de abuso. No tocante aos ativos ambientais o direito de uso ocorre quando estes ganham utilidade, posteriormente, importância econômica, como o extrativismo; o direito de usufruto quando ocorrer a possibilidade de obter renda como por exemplo a exploração de minas de carvão; e o terceiro, a venda na modalidade de crédito de carbono.

Nesse contexto, pode-se considerar que o esgotamento dos recursos naturais, oriundos dos ativos ambientais, decorre da fragilidade do ambiente institucional, dado o estabelecimento muitas vezes não adequado da estruturação dos direitos de propriedade.

Importa lembrar que a teoria dos direitos de propriedade fornece uma explicação de como as empresas podem criar arranjos organizacionais, a fim de explorar plenamente seu patrimônio. Esta teoria está ligada àquela de contratos e direitos de propriedade na escolha dos arranjos (MONTEIRO; ZYLBERSZTAJN 2011).

Dessa forma, identifica-se, na relação de exploração de serviços ambientais entre compradores e vendedores, a apropriação do direito econômico da propriedade manifestado pela melhoria das condições de preservação do meio ambiente e das relações interpartes.

Para acontecerem de forma racional, a apropriação e as melhorias de condições do meio ambiente dependem de no mínimo dois fatores: por um lado, o ambiente institucional, e por outro, como esse ambiente afeta os contratos. Os contratos são os meios pelos quais os direitos de propriedade são estabelecidos, transferidos outorgados ou cedidos. Nesse contexto, 
há, portanto, duas indagações fundamentais. Primeiro, quais são os direitos que podem ser estabelecidos, transferidos ou cedidos? Segundo, como lidar com as promessas não cumpridas, ou seja, como indenizar, ou melhor, ressarcir a transgressão de direitos que foram transferidos outorgados ou cedidos?

Para responder a esses questionamentos, torna-se necessária a investigação na literatura que trata de contratos que desempenham um papel igualmente central na organização da atividade econômica dos bens e serviços ambientais, uma vez que são a base de sustentação de muitas transações realizadas no mercado, em especial as de maior complexidade.

Em geral, grande parte dos negócios realizados é instrumentalizada por meio de contratos, nos quais leis e regulamentos definem limites bem claros para que sejam considerados válidos, ou seja, as transações de mercado definem preços e quantidades envolvidos segundo as restrições legais (ANUATTI NETTO, 2011).

Assim, é possível afirmar que as regras que condicionam o funcionamento dos mercados, impõem limites ao emprego de recursos e afetam diretamente os custos de realizar e cumprir contratos. A alocação de recursos na sociedade está sempre associada ao sistema de atribuição de direitos, cuja função principal é atribuir aos titulares dos ativos autoridade de escolher o uso específico desejado entre uma classe de usos possíveis e não proibidos, bem como impedir que outros tenham acesso a esses recursos, ou seja, que tal atribuição seja exclusiva do titular (ANUATTI NETTO, 2011).

A atividade de atribuição de direitos de comando sobre determinado ativo comporta três categorias:

\footnotetext{
a) direitos de uso - nessa categoria o titular pode decidir como irá usufruir, transformar ou mesmo distribuir o ativo;

b) direitos de exploração - nessa categoria o titular pode decidir de que maneira irá auferir a renda do ativo, seja explorando-o diretamente, seja contratando outros para fazê-lo;

c) direito de alienação - nessa categoria se define a capacidade de o titular transferir de forma permanente o ativo a outros, ou seja, o direito de alienação (ANUATTI NETTO, 2011, p. 248).
}

Em acontecendo de os três direitos sobre o mesmo ativo serem atribuídos ao mesmo titular, encontram-se, nesse caso, os direitos de propriedade plena, conceito trazido por Anuatti Netto (2011). 
Ressalte-se que Alchian (1977) afirma que os direitos de propriedade plena não são uma tarefa simples, exemplificando essa dificuldade com o direito sobre o ativo terra, já que os direitos de propriedade privada para as várias parcelas de usos da terra "pertencem" a pessoas diferentes.

Ainda, a literatura aponta para a dificuldade de identificar em uma única pessoa a titularidade dos direitos; no momento em que isso for possível, surge a propriedade individual plena, que é conceituada por Anuatti Netto (2011, p. 248) como sendo "a condição de uma única pessoa possuir a titularidade dos direitos".

Nesse mesmo sentido, as possibilidades de propriedade plena estatal, coletiva e comum, ou de livre acesso, são diferenciadas da seguinte forma:

a) propriedade plena estatal considerada a titularidade dos recursos sendo exercida pelo Estado;

b) propriedade plena coletiva considerada a titularidade dos recursos sendo exercida pela comunidade ou por seus representantes;

c) propriedade comum, nesse caso, os ativos podem ser deixados na forma de livre acesso (ANUATTI NETTO, 2011, p. 248).

O estabelecimento e a garantia dos direitos exclusivos de propriedade demandam medidas custosas por parte dos indivíduos e do Estado; tais medidas são tomadas pelos agentes privados, estatais ou coletivos, quando seus custos são inferiores aos rendimentos esperados. Do contrário, os agentes econômicos arcam com os custos de garantir o uso exclusivo de seus ativos. Nesse caso, mesmo sendo escassos e possuindo valor econômico, os ativos podem ser deixados na forma de livre acesso (EATON; EATON, 1999).

Por outro lado, quando o Estado é incapaz de assegurar ou recusa-se a garantir contratos entre agentes econômicos que disputam a utilização dos mesmos recursos, surge a figura dos recursos de livre acesso, ou seja, situação em que não existe autoridade governamental capaz de regulamentar o uso de certos ativos (EATON; EATON, 1999, p. 22).

O Estado poderá ainda impor limitações aos direitos exclusivos de propriedade, que podem ser as proibições e as atenuações. Importa deixar consignado que qualquer redefinição numa estrutura de direitos de propriedade feita pelo Estado tem efeitos sobre a riqueza, gerando perdedores e ganhadores. Quanto maiores forem as garantias que o Estado oferece ao titular 
de direitos exclusivos de propriedade, maior será o valor de um ativo, pois isso permitirá o emprego livre desses recursos nas atividades de maior retorno.

Para Anuatti Netto (2011), em um sistema econômico em que todos os agentes dispõem das informações necessárias e não têm razões para esperar que os outros não cumpram o contratado, todos os recursos de valor econômico poderiam ser delineados e a titularidade dos direitos de propriedade atribuídas. Uma vez estabelecidos os direitos exclusivos de propriedade, pode-se garantir que todos os recursos sejam empregados em atividades em que o rendimento econômico seja máximo, não sendo necessária a interferência do Estado. Essa situação corresponde a uma alocação eficiente segundo o ótimo de pareto.

Portanto, enquanto assinalar direitos de propriedade é essencial para a transação no mercado, o resultado último (em termos de maximização do valor da produção) independe de como a lei os assinala, desde que não exista custo de transação, ou seja, quando os direitos de propriedade são bens definidos e o custo de transação é igual a zero, a solução final do processo de negociação entre as partes será eficiente, independentemente da parte a que se assinalam os direitos de propriedade.

\subsubsection{Falhas de mercado}

Falhas de mercado resultam da existência de bens públicos e de efeitos externos não captados pelo mercado, são falhas na proteção dos direitos de propriedade. Bens cuja produção não afeta os custos, ou seja, cujo custo marginal de produção é zero, não podem ser precificados. Bens cuja produção ou cujo consumo afetam a produção ou o consumo de outros bens, geram externalidades. Bens cujo uso seja aberto a toda a sociedade, serão exauridos. Ambos representam falhas de mercado. As externalidades e os bens públicos estão na raiz do conceito de falhas de mercado.

A solução tradicional para os problemas das falhas de mercado é a intervenção governamental, que admite a possibilidade de que a regulação, alterando a forma como o mercado funciona, venha a produzir uma situação de maior bem-estar social do que se deixasse o mercado funcionar sem interferência. Essa é a justificativa usual por trás da 
regulação: tentar melhorar a alocação dos recursos, corrigindo ou contrapondo-se aos efeitos das chamadas falhas de mercado.

A existência de externalidades faz com que nem todas as interações que ocorrem entre os agentes econômicos sejam intencionais e resultantes de acordos mútuos. Existem externalidades quando um agente econômico não incorre nem incorpora todos os custos associados a uma transação. Nesse caso, o preço pago pelo consumo de um produto não reflete o custo, para a sociedade, de produzi-lo.

Na mesma direção, quando os agentes econômicos realizam trocas com base em informações incompletas sobre custos e benefícios que cada um terá como resultado de uma transação, o mercado falha e, por conta própria, não maximiza o bem-estar social. Um caso em que isso ocorre é quando há uma assimetria de informação entre os agentes, isto é, quando uma das partes na transação sabe mais sobre o bem ou serviço transacionado do que a outra.

$\mathrm{Na}$ análise de Coase (1937) sobre a eficiência do mercado e a internalização das externalidades, nomeadamente as negativas, a eficiência não resulta só da diminuição dos custos de transação. Coase pergunta se a tese da intervenção é a única solução e indagou a respeito de soluções alternativas à da regulação. Essa questão tem importância para o debate do tema da precificação de serviços ambientais.

O Estado deve limitar-se, num primeiro momento, por exemplo, a atribuir direitos de poluir, se estes não tiverem sido já assumidos pelos agentes econômicos e distribuídos entre si, bem como a atribuir direitos sobre os recursos até há pouco de acesso livre. Depois desse primeiro momento, o Estado só deve intervir se o mercado revelar-se completamente ineficiente, e se houver grandes distorções no mercado, por serem demasiado elevados os custos de transação. Assim, quais intervenções têm mais chances de conseguir gerar o ganho de bem-estar social, ou seja, ser eficiente? É o que será analisado em seguida.

As falhas de mercado podem ser resultantes da existência de externalidades, de uma distribuição assimétrica de informação e de monopólios naturais. E, ainda, quando o mercado não é competitivo, e uma ou mais empresas gozam de poder de mercado, isto é, da habilidade de fixar seu preço acima do custo marginal. Quando isso acontece, há uma eficiência alocativa, e o consumo dos bens ou serviços produzidos por essas empresas ficará abaixo do 
nível que maximiza o bem-estar social. Assim, pode-se resumir que as falhas de mercado decorrem do poder de mercado de monopólios e oligopólios, ou mesmo das assimetrias de informações, assim como das preferências ou da decisão de produção de determinados agentes.

A partir dessa análise inicial, fica evidente que muitos mercados são ineficientes, em função de restrições tecnológicas, restrições regulatórias, falta de informação e barreiras à entrada, onerando toda a sociedade, em benefício de poucos. As especificidades nas falhas de mercado são passíveis de soluções resumidas no Quadro 1.

Quadro 1 - Falhas de Mercado e Soluções

\begin{tabular}{|l|l|}
\hline \multicolumn{1}{|c|}{ Falhas de Mercado } & \multicolumn{1}{c|}{ Soluções } \\
\hline Existência de bens não-exclusivos (res comunis) & Definição e enforcement de direitos de propriedade \\
\hline Existência de bens não-rivais & Regras de cumprimento de contratos privados \\
\hline Poder de monopólio & $\begin{array}{l}\text { Regulamentação de atividades sujeitas ao exercício do } \\
\text { poder do monopólio }\end{array}$ \\
\hline $\begin{array}{l}\text { Mercados incompletos (externalidades, mercados para } \\
\text { todos os possíveis estados da natureza) }\end{array}$ & Provisão de bens públicos ou coletivos \\
\hline
\end{tabular}

FONTE: Farina (1999)

Outro ponto a registrar é que o mercado por si só não garante a eficiência. O Estado é fundamental para que o mercado exista, pois o mercado existe, porque existe propriedade, e a propriedade é tal, porque assim é definida e protegida também, mas não apenas pelo Estado. Para Troster (2011), há uma série de bens aos quais o mercado não assegura uma alocação eficiente, exemplo disso são os bens públicos, a defesa nacional e outros, que fazem com que a quantidade a ser produzida e os recursos a serem alocados sejam decididos de forma mais eficiente num processo político.

Nos sistemas de mercado em que produtores e consumidores transacionam em uma estrutura de mercado concorrencial, os recursos considerados escassos são, por pressuposto, empregados com o máximo de eficiência alocativa, o que resulta na situação de equilíbrio para cada agente e para a economia como um todo. Nessa situação, nenhuma transação voluntária entre os agentes poderia melhorar a situação de um sem piorar a de outros (ANUATTI NETTO, 2011, p. 246). Trata-se da denominação de Ótimo de Pareto, situação em que os recursos são alocados de tal maneira que nenhuma reordenação diferente possa melhorar a situação de qualquer pessoa (ou agente econômico) sem piora a situação de alguma outra. 
Para o autor, na hipótese de que todas as estruturas dos mercados em uma economia sejam de concorrência perfeita, com a ausência de falhas de mercado, pode-se assegurar que um sistema de mercado é capaz de conduzir ao melhor uso dos recursos numa sociedade em que cada agente econômico procura os próprios interesses. Entretanto as estruturas observadas não são concorrenciais, afastando-se do paradigma.

Ademais, nas sociedades de mercado modernas, predominam estruturas de mercado de concorrência imperfeita. Isso leva à necessidade de discutir, quando se defronta com essa e outras falhas de mercado, se o uso eficiente dos recursos escassos requer intervenção governamental. Cabe ao economista ser capaz de apontar de que maneira tais interferências devem ocorrer.

Assim, é de fundamental importância discutir as circunstâncias que levam à ineficiência alocativa dos sistemas de mercado, ressaltando a existência de regras que, explícita ou implicitamente, regem seu funcionamento, e além disso apontar as agências e os instrumentos de que o Estado dispõe para a regulamentação dos mercados.

A afirmação da presença do estado em todos os mercados somente é possível quando se sanciona um sistema de atribuição de direitos, não confundido com intervenção. As intervenções específicas, denominadas de regulamentação de mercados, são exatamente as que restringem a oferta e a demanda num mercado, tais como controle de preços, restrições à entrada de novos produtores, imposição de atendimento aos consumidores de determinada área, especificação de características de produtos ou de tecnologias a serem empregadas na fabricação, e imposição de padrões ambientais no local de trabalho e fora da firma (ANUATTI NETTO 2011, p. 248).

Esse autor aduz que por regulamentação dos mercados entende-se o conjunto de regras particulares para interferir no mecanismo de alocação de mercado ou alteração das decisões de oferta e demanda de consumidores e produtores.

Conclui-se primeiramente que, se o sistema de mercado assegura o uso eficiente dos recursos para a produção de bens em caráter privado desde que as condições discutidas nas estruturas de mercados eficientes sejam satisfeitas, a regulamentação decorre da busca de soluções para o problema gerado pela existência de falhas de mercado. Segundo, formular e implementar a regulamentação de um mercado requer elevados custos administrativos, leva à redistribuição 
de rendimentos e pode interferir na eficiência alocativa de outros mercados; requer, portanto, recursos que não podem ser ignorados quando se comparam os ganhos de eficiência na introdução da regulamentação com as ineficiências de um mercado não regulamentado, mas que apresenta alguma falha.

Pindyck e Rubinfeld (2005) afirmam que merece ser compreendida a funcionalidade dos mercados. Estes estão no centro da atividade econômica, e muitas das questões mais interessantes da economia estão relacionadas com seu modo de funcionamento. Para chamar atenção para o problema, os autores formulam uma série de questões: Por que apenas um pequeno número de empresas concorre entre si em alguns mercados, enquanto em outros há um grande número? Será que consumidores ficarão mais satisfeitos se existirem muitas empresas? Em caso afirmativo, o governo deveria intervir em mercados que tenham apenas algumas empresas? Por que os preços, em alguns mercados, têm subido ou caído rapidamente, enquanto em outros dificilmente sofrem alguma alteração? Quais mercados oferecem as melhores oportunidades para um empreendedor que esteja pensando em entrar no mundo dos negócios?

A partir desse questionamento, dois pontos justificam a definição de mercado: primeiro, qualquer negócio (empresa) necessita saber quem são seus reais e potenciais concorrentes para os produtos por ela comercializados ou que poderia vir a comercializar no futuro, para que então tenha condições de identificar os limites de seu produto e limites geográficos, a fim de fixar preços e determinar investimentos; e, segundo, o negócio fornece subsídios ao governo para as escolhas de políticas públicas (PINDYCK; RUBINFELD, 2005).

Varian (2012) defende que, sendo o mercado o local em que ocorre a fixação de preço, um critério empregado para a extensão de qualquer mercado são justamente os preços, ou seja, se os preços de um produto em diferentes regiões geográficas (ou de diferentes tipos de produtos) são aproximadamente os mesmos, ou se variam em conjunto. Dessa forma, caso venha a ocorrer qualquer uma dessas situações, poderá ser considerado que se trata de um mesmo mercado. O conceito de mercado relevante apoia-se no alcance dos efeitos agentes sobre o mercado. Ausentes quaisquer efeitos, serão os mercados considerados separados.

Para estudar os efeitos da estrutura de mercado sobre os preços e as quantidades de equilíbrio, os economistas trabalham com alguns modelos simples que se diferenciam pelo grau de 
competição existente entre as firmas e que serão analisados ao longo do estudo. Entretanto, citam-se de forma simples os argumentos dos mercados perfeitamente competitivos versus mercados que não sejam completamente competitivos. O primeiro é o mercado com muitos compradores e vendedores, de tal modo que nenhum comprador individual tem impacto significativo no preço, e há a prevalência geralmente de um único preço. O segundo possui muito produtores, mas são considerados não competitivos, uma vez que determinadas empresas podem afetar o preço do produto, podendo os vendedores cobrar diferentes preços (PINDYCK; RUBINFELD, 2005, p. 7). O segundo, como modelo de estrutura oposto ao de concorrência perfeita, é o monopólio. Neste, apenas uma firma supre todo o mercado. Esta é uma situação que pode surgir por motivos diferentes, como, por exemplo, haver restrições legais à entrada de outras empresas. Na análise de um mercado específico, a microeconomia vale-se da hipótese de que tudo o mais permanece constante (em latim, ceteris paribus), sendo o foco de estudo dirigido apenas àquele mercado, analisando-se o papel que a oferta e a demanda nele exercem e supondo que outras variáveis interfiram muito pouco, ou que não interfiram de maneira absoluta (VASCONCELOS, 2011, p. 12).

Assim, nos estudos econômicos, vários autores concluem que a firma tem como objetivo básico a maximização de seus resultados quando realiza sua atividade produtiva, e sempre procurará obter a máxima produção possível em face da utilização de certa combinação de fatores. Conclui-se que a firma deve maximizar seus lucros com toda informação e certeza disponíveis, sob certas condições de demanda, e, em consequência, o produto final, sua estrutura de preço e os insumos escolhidos podem diferir se a firma vende num mercado competitivo perfeito ou imperfeito.

Troster (2011, p. 25) aduz que as estruturas de mercado resultam de características comuns decorrentes da interação entre os agentes (atores), e dessa interação a oferta e a demanda mostram-se distintas em cada mercado, visto existirem características específicas de produtos, condições tecnológicas, acesso a informação, tributação, regulamentação de participantes, localização no espaço e no tempo que tornam único esse mercado. Acrescenta o autor que são modelos que captam aspectos inerentes de como os mercados estão organizados, sendo que cada mercado destaca alguns aspectos essenciais da interação entre a oferta e a demanda e baseia-se em algumas hipóteses e no realce de características observadas em mercados existentes, como o tamanho das empresas, a diferenciação dos produtos, a transparência do mercado, os objetivos dos empresários e o acesso de novas empresas, entre outras. 
As estruturas de mercado englobam as características que influenciam o tipo de concorrência e a formação dos preços: primeiro, o grau de concentração de vendedores e compradores, isto é, número e tamanho de cada um no mercado; segundo, grau de diferenciação do produto, ou seja, grau em que um produto vendido no mercado é considerado diferente ou não homogêneo pelos compradores.

Com base nos elementos essenciais da estrutura de mercado, notadamente o número de firmas e a diferenciação do produto, os mercados são classificados. Segundo Troster (2011), os mercados podem ser:
a) estruturas clássicas básicas: o monopólio e a concorrência perfeita;
b) outras estruturas clássicas: concorrência monopolista de oligopólio; oligopólio; monopsônio; monopólio bilateral;
c) modelos marginalistas de oligopólio, destacam-se os principais: modelo de Vournot; o modelo de Sweezy; o cartel perfeito; e os modelos de liderança-preço (TROSTER, 2011, p. 204).

O modelo de mercado frequentemente utilizado é o de concorrência perfeita, nele se assumindo que existem muitos consumidores e muitas firmas, todos de tamanho pequeno em relação ao mercado como um todo.

Da mesma forma, as falhas de mercado podem existir em estruturas de mercado que venham a operar em concorrência perfeita, impedindo dessa forma a ocorrência de solução de eficiência na alocação de recursos escassos (ANUATTI NETTO, 2011, p. 247).

As falhas de mercado originam as condições para que ocorra a intervenção do Estado na economia. Essas falhas, imperfeições ou inoperabilidades podem invalidar ou limitar a capacidade explicativa das teorias liberais e, ainda, podem gerar resultados ineficientes para a sociedade, com a presença de externalidades, independentemente de seu tipo, o que se transforma em perturbação do normal funcionamento do mercado, isto é, em falhas de mercado.

A indagação feita por Anuatti Netto (2011) merece atenção no estudo do pagamento por serviços ambientais: "Será que a solução de mercado é adequada para a organização de recursos escassos na satisfação das necessidades materiais dos indivíduos?”. 
É preciso sempre levar em consideração, nos negócios da vida cotidiana, que produtores e consumidores não estão isentos da incerteza, do oportunismo, dos custos de obter e processar informações. Nesse sentido, pergunta-se se é possível esperar que as soluções dadas pelo mercado sejam sempre inadequadas. $O$ ambiente de incerteza em que se realizam as transações é facilmente constatado, pois se fazem negócios em que se comprometem questões futuras, mas muitas vezes não se tem como antecipá-lo nem como controlá-lo. Ainda é preciso levar em consideração que existem pessoas oportunistas, dispostas a renunciar a um contrato quando a oportunidade melhor lhes parecer. E, por fim, o fato de que, para tomar uma decisão, tem-se que investir tempo e recursos para obter as informações necessárias (ANUATTI NETTO, 2011).

A possibilidade objetiva de intervenção está prevista no artigo 174 da Constituição Federal (BRASIL, 1988), que admite que o Estado como agente normativo e regulador da atividade econômica, exercerá, na forma da lei, as funções de fiscalização, incentivo e planejamento, sendo este determinante para o setor público e indicativo para o setor privado.

Dessa maneira, as falhas de mercado traduzem-se em campo fértil capaz de justificar a intervenção do Estado no domínio econômico para, no mínimo, corrigi-las. Observa-se nas características do Estado brasileiro a possibilidade da aplicação das condições teóricas a essa realidade. Isto implica dizer que o Estado/direito - apesar da resistência dos liberais - acaba ainda tendo um grande papel a desempenhar no domínio econômico.

O liberalismo econômico, intrinsecamente lógico e coerente, é entendido como a corrente de pensamento das ciências econômicas influenciada pelas ideias de "laissez faire, laissez passer" " dos fisiocratas franceses e pela obra de Adam Smith - que se tornou hegemônica após o fim da bipolarização capitalismo x socialismo, e que salienta a importância da liberdade individual nas atividades econômicas em face da intervenção do Estado. Nessa linha de pensamento, a economia poderia funcionar melhor (de maneira mais eficiente), quando o mercado é levado por sua própria racionalidade e por sua dinâmica. Portanto, o Estado/governo/direito deveria abster-se de intervir no domínio econômico sistematicamente. Nesse sentido, o discurso liberal sustenta que:

\footnotetext{
${ }^{9}$ A tradução da expressão em francês significa: "Deixe fazer, deixe passar (comercializar)"
} 
deveria ser dada a possibilidade aos indivíduos de perseguirem seus próprios interesses e desejos e que as atividades do Estado deveriam ser limitadas à garantia dos contratos e a proporcionar o policiamento e a defesa nacional, possibilitando deste modo a máxima liberdade individual (SAMUELSON, 1987 p. 857).

Neste paradigma científico-ideológico, a validade intrínseca do liberalismo depende da ocorrência de uma série de circunstâncias e condições, que são os pressupostos necessários para que os conceitos e explicações tenham coerência interna, possibilitando então a sua aplicação. Dentre vários pressupostos, incluem-se a racionalidade ${ }^{10}$, a plena informação ${ }^{11}$, a ausência de externalidades $^{12}$; a concorrência perfeita ${ }^{13}$; a racionalidade $x$ paternalismo $^{14}$; e a concorrência perfeita $\mathrm{x}$ poder de mercado ${ }^{15}$.

Contudo, as premissas e os pressupostos sobre os quais este marco teórico é construído muitas vezes não se verificam na prática, visto que nem sempre é possível ter-se o conhecimento de todas as informações de que se precisa sobre os bens que são consumidos, os recursos disponíveis, as empresas em que se investe ou as concorrentes que são enfrentadas, levando à premissa de plena informação versus falha de informação.

Por isso, parece ser importante o governo intervir criando normas que obriguem os fornecedores a prestarem informações sobre os produtos que são consumidos, que obriguem os administradores a informar aos acionistas sobre o real desempenho das companhias, ação que tem reduzido os casos em que consumidores ou concorrentes são lesados.

\footnotetext{
${ }^{10}$ Os indivíduos são sempre racionais (e inteligentes) na maneira pela qual utilizam os recursos escassos; como seres racionais, os homens almejam aumentar sua riqueza e por isso tentam agir de maneira economicamente eficiente (SAMUELSON, 1987).

${ }^{11}$ Os indivíduos têm informação suficiente para saber como alocar seus recursos escassos de maneira eficiente, maximizando assim sua riqueza (SAMUELSON, 1987).

${ }^{12}$ Inexistência de quaisquer efeitos nocivos ou benéficos que uma empresa/pessoa impõe à sociedade e que não são incorporados ao preço dos produtos e serviços fornecidos por ela (SAMUELSON, 1987).

${ }^{13}$ Mercado em que nenhum fornecedor ou comprador tem, por si, força suficiente para afetar o preço praticado no mercado (poder de mercado), inexistindo, portanto, monopólios, oligopólios, cartéis, entre outras (SAMUELSON, 1987).

${ }^{14}$ Nem sempre as pessoas são racionais, muitas vezes são impulsivas, emotivas, loucas ou simplesmente tolas. Em muitos desses casos, o Estado intervém na liberdade, pressupondo que às vezes ocorra o comportamento irracional, e impõe obrigações como usar cintos de segurança e vacinar os filhos, ou proibições, como as relacionadas à celebração de contratos ou ao exercício de certas atividades profissionais (SAMUELSON, 1987).

${ }^{15}$ No mundo real, a expressiva maioria dos mercados não apresenta as características de concorrência perfeita, ou seja, nenhum fornecedor ou comprador tem, por si, força suficiente para afetar o preço praticado no mercado. É muito comum que uma ou algumas empresas detenham esse poder de mercado e disso resultam falhas de mercado como monopólios, oligopólios, cartéis, entre outras, que geram perdas de eficiência e por isso precisam ser regulados e fiscalizados pelo governo (SAMUELSON, 1987).
} 
Cada tipo de falha de mercado, pode estar associada a uma instituição, ou conjunto de instituições, que varia de país para país e também ao longo do tempo.

Inúmeros são os instrumentos disponíveis para contornar as falhas de mercado e garantir a melhoria da eficiência alocativa numa economia de livre iniciativa. Destaca-se a classificação genérica adotada por Anuatti Netto (2011, p. 250):

a) comando e controle que são aqueles associados a regras particulares implementadas por agências governamentais, especialmente concebidas para esses fins, fazendo uso de regulamentos e sanções;

b) incentivos financeiros que estão associados a transferências de recursos por meio de impostos e subsídios (ANUATTI NETTO, 2011, p. 250).

Vários são os sistemas de regulamentação que procuram regular as falhas de mercado associadas a eles, assim como os instrumentos por ele empregados. No Brasil os sistemas de regulamentação Brasil alguns são: regulamentação de serviços de utilidade pública, em que os mercados falham na presença dos chamados bens públicos ${ }^{16}$, sendo que esses bens com características de bens públicos são a defesa nacional, a lei e a ordem, a saúde pública, a ciência básica, a infraestrutura de transporte e urbana, os parques, vias, iluminação; o sistema de defesa da concorrência em que "os mercados falham na presença de concorrência imperfeita, ou seja, quando as firmas podem atuar num mercado específico de modo a fixar seus preços acima dos custos marginais de produção"; o sistema de defesa do consumidor (SNDC): os mercados falham quando, dado um sistema de atribuição de direitos, os custos e os benefícios de uma transação, para cada agente envolvido, não são explicitamente definidos nos termos do contrato; e o sistema de proteção do meio ambiente em que "os mercados falham quando as transações num mercado produzem efeitos positivos ou negativos a terceiros, ou seja, causam externalidades" (ANUATTI NETTO, 2011).

Esses efeitos dão origem a custos ou benefícios para terceiros, não refletidos nos custos de transacionar dentro do mercado, levando à super ou subexploração dos recursos. O papel da regulamentação nesses casos é o de avaliar os custos externos e redistribuí-los aos que lhes deram origem.

\footnotetext{
${ }^{16}$ Estes "são aqueles para os quais o consumo por parte de um indivíduo não reduz a capacidade de outros de usufruir dos seus serviços, porque, como as empresas privadas não dispõem de elementos para cobrar de cada consumidor, também não terão incentivos para ofertar tais bens" (ANUATTI NETTO, 2011, p. 250).
} 
Pode-se afirmar que as dificuldades técnicas e informacionais sobrepõem-se às dificuldades de identificar corretamente os direitos de propriedade envolvidos. Como repartir a responsabilidade pela poluição atmosférica numa grande cidade? Quanto dela caberá aos proprietários de veículos, às indústrias, entre outros? Se a responsabilidade civil dos que causam a poluição fosse facilmente identificada, o conjunto geral de leis que disciplina o assunto seria suficiente para que qualquer dano causado a terceiros viesse a ser compensado. Nesse caso, não haveria necessidade de regulamentação e de agências governamentais especificamente concebidas para esse fim. Porém, os direitos de uso exclusivo não são completamente definidos e os recursos naturais podem tornar-se, com efeito, de livre acesso (ANUATTI NETTO, 2011, p. 260). Assim, a solução de casos de propriedade comum ${ }^{17}$ de recursos requer discussão também dos direitos de propriedade que eliminem o livre acesso.

\subsubsection{Teorema de Coase e as externalidades}

A análise das externalidades foi também empreendida por Coase (1937). O autor põe em evidência uma característica muito especial das externalidades, a reciprocidade. Para Coase (1937), a reciprocidade significa que nas externalidades não estão presentes somente os que produzem a externalidade e as vítimas dessa externalidade (quem a sente como ônus). Então, pelo contrário, dois externalizadores que recebem vantagens (externalidades positivas) ou reciprocamente se impõem ônus (externalidades negativas), sem que esta bilateralidade envolva simetria das vantagens ou dos ônus. A reciprocidade das externalidades evidencia a interdependência das decisões dos agentes econômicos. É essa interdependência que permite negociar as externalidades, isto é, abrir mercado para as externalidades.

Detectada a reciprocidade ou bilateralidade das externalidades, Coase (1937) inclina-se para a hipótese de sua internalização no mercado. Concebe um mercado que, a exemplo do mercado dos produtos que se vendem e se compram, negocie externalidades de modo a encontrar soluções de equilíbrio, soluções que a sociedade aceite consensualmente e absorva.

\footnotetext{
${ }^{17}$ Os casos de propriedades comuns foi tratado por Garret Hardin (1968), em seu artigo "Tragédia dos comuns". Nele Hardin comparou o problema do crescimento descontrolado da população ao problema histórico do excesso de uso de pastagens comunitárias por habitantes rurais da Inglaterra. O autor previu que, assim como fazendeiros individuais continuavam a acrescentar uma vaca, e depois outra, aos terrenos comuns até que a terra de pastagem estivesse devastada pelo excesso de uso, os seres humanos também poderiam muito bem produzir uma criança, depois outra, até que os recursos do mundo fossem completamente exauridos por uma população grande demais para ser mantida ela capacidade limitada da terra.
} 
A novidade que a concepção de Coase $(1937){ }^{18}$ trouxe reside, pois, em permitir a internalização das externalidades, não por força da intervenção do Estado mas por meio de mudanças institucionais que definam direitos de propriedade, reduzindo os custos transacionais e aumentando as possibilidades de soluções negociadas à alocação dos direitos de propriedade.

Assim, é preciso ter presente que a poluição - tipicamente tratada como uma externalidade possa ser controlada, chegando a um equilíbrio no qual as partes negociem sua redução ou a realocação, a negociação, o ressarcimento, dos efeitos externos. É essa percepção que torna possível não só calcular o nível eficiente de poluição como atribuir um valor ao direito de poluir (que traduz o custo do exercício de um direito). Dessa forma realista e não panfletária, Coase traz a clara percepção de que o nível de poluição socialmente aceito, pode não ser zero, fato que ainda causa debates entre o público menos informado. Essa valoração é função de uma perda sentida pelo exercício desse direito - perda de ar puro, perda de água de qualidade, entre outros. O exercício do direito (ou o uso de um fator de produção) passa, desse modo, a ter um custo, um custo que o produtor-poluidor paga (licença), dentro do limite calculado para a possibilidade de poluir.

Dessa maneira, as soluções a que eficientemente se chega partem da ideia de Coase (1937) de que as externalidades têm uma natureza bilateral, e de que essa natureza permite a formação de um mercado que as internaliza. Os agentes causador e receptor do efeito externo são corresponsáveis por encontrar uma solução. Moldado para satisfazer a necessidade de internalizar as externalidades, esse mercado tem-se diversificado em fórmulas várias, desde o mercado de quotas negociáveis, que está na base do Protocolo de Quioto, à fórmula da bolsa ecológica na internet (DAILY; ELLISON, 2002).

Por sua vez, Coase (1937) verificou que o mercado que permite internalizar as externalidades não pode ser integralmente eficiente porque é contaminado e, logo, distorcido, pelo custo de transação. Este diz respeito à obtenção de informação e ao conhecimento sobre direitos envolvidos, número e tipo de interessados e estatuto jurídico, cumprimento dos tratados ou

\footnotetext{
${ }^{18}$ Tenha-se, porém, presente que o ambiente como questão não foi o objeto da análise de Coase, embora múltiplos exemplos que o autor apresenta, tirados da vida real ou imaginados, têm em regra atenção aos custos marginais sociais traduzidos em poluição que as atividades produtivas provocam (COASE, 1960).
} 
acordos, condicionantes que permitem criar, em relação à decisão a tomar, a certeza possível. Para o autor, o mercado só funcionará de forma eficiente se não houver custos de transação, que estão relacionados ao que o mercado desenvolve, ao conhecimento que as empresas devem possuir, e que as obriga a ter conhecimentos especializados em diferentes domínios.

O reconhecimento de direitos de apropriação dos bens naturais está na base da concepção de Coase (1937). Com efeito, se, nos aspectos em que as externalidades negativas se formam, for possível encontrar um titular de direitos que reaja, ou, nos aspectos em que houver externalidades positivas, for possível encontrar alguém que delas se beneficie e possa assumir uma posição negociadora, em razão da titularidade do benefício, está encontrada numa via de mercado para solucionar problemas ambientais que hoje se podem considerar insolúveis. A questão é conseguir controlar os custos de transação para que a eficiência funcione em pleno mercado.

No mundo real, os custos de transação são positivos, existindo dificuldades para o funcionamento dos mercados. Esta é a mensagem central de Coase, que sugere a necessidade de se compreenderem as organizações em condições de custos positivos de transação. É o caso do oxigênio, da água e do carbono. Assim as ideias-chave do pensamento de Coase (1937) estão enunciadas: reciprocidade das externalidades, apropriação dos bens ambientais e identificação dos titulares de direitos e existência de custos de transação.

$\mathrm{O}$ entendimento do conceito de pagamento por serviços ambientais, pano de fundo do presente trabalho, leva à necessidade do aprofundamento do conceito de externalidades e dos caminhos para a correção das mesmas. Numa abordagem mais técnica, a noção de compensação tem como base a concepção de Pigou (1920) e a teoria de Coase (1937), ressaltando-se que a noção de externalidades tem seus fundamentos na teoria microeconômica.

As externalidades podem surgir entre produtores, entre consumidores ou entre consumidores e produtores. Para Hubbard e O'Brien, (2010, p. 194), a externalidade é um benefício ou custo que afeta alguém que não está diretamente envolvido na produção ou consumo de um bem ou serviço. Há externalidades negativas ${ }^{19}$ - que ocorrem quando a ação de uma das partes impõe

\footnotetext{
${ }^{19}$ Como exemplo, as pessoas que sofrem de asma podem arcar com um custo, apesar de não estarem envolvidas na compra ou na venda da energia elétrica que causou a poluição.
} 
custos à outra-, e externalidades positivas ${ }^{20}$ - que surgem quando a ação de uma das partes beneficia a outra.

Isso significa dizer que as externalidades estão vinculadas aos efeitos das atividades de produção e consumo que não se refletem diretamente no mercado. As decisões de compradores e vendedores influenciam mutuamente uns aos outros, ou seja, são resultados de mercado, e isso não é uma externalidade (EATON; EATON, 1999).

A literatura traz como exemplo clássico uma fábrica de pneus que polui o ar com fumaça e o rio com resíduos tóxicos. A poluição causa externalidades, pois a fumaça provoca doenças respiratórias em crianças que estudam por perto, e os resíduos matam os peixes do rio. Tanto os custos com as despesas médicas com as crianças, quanto o prejuízo dos pescadores poderia ser evitado se a fábrica instalasse filtros nas chaminés e nas saídas de esgotos. Ela poderia diluir os gastos com esses investimentos no preço dos pneus, de maneira a repartir essa despesa com o consumidor. Mas como a fábrica não quer aumentar o preço do pneu para não perder clientes, ela não o faz. E isso gera resultados ineficientes para sociedade. Nesse contexto, o Estado deve intervir criando normas que proíbam a poluição, obrigando as fábricas a instalar os filtros. Os custos serão repassados aos consumidores depois, mas de maneira muito diluída.

Nesse caso, Chagas (2011, p. 284) afirma que "a fábrica causadora de poluição não tem incentivos para incorporar os custos sociais no seu processo de tomada de decisão, o que a levará a produzir uma quantidade de poluição bem maior que o socialmente ótimo”.

Hubbard e O'Brien (2010, p. 194) destacam que as externalidades afetam diretamente a eficiência econômica de equilíbrio de um mercado, pois causam uma diferença entre o custo privado $^{21}$ e o custo social ${ }^{22}$, ou entre o benefício privado ${ }^{23}$ e o benefício social ${ }^{24}$ do consumo. Salvo a ocorrência de uma externalidade, o benefício privado e o benefício social são iguais afirmam Hubbard e O’Brien (2010, p. 194).

\footnotetext{
${ }^{20}$ Em relação às externalidades positivas, tem-se como exemplo as pessoas que podem beneficiar-se das pesquisas médicas, mesmo não estando diretamente envolvidas em sua realização.

${ }^{21}$ É o custo de um bem ou serviço com que o produtor arca (HUBBARD; O’BRIEN, 1999, p. 194).

${ }^{22}$ É o custo total de produzir um bem ou serviço incluindo tanto o custo privado quando o custo externo decorrente da produção, como o custo da poluição (HUBBARD; O’BRIEN, 1999, p. 194).

${ }^{23}$ É o benefício auferido pelo consumidor de um bem ou serviço (HUBBARD; O'BRIEN, 1999, p. 39, p. 195).

${ }^{24}$ É o benefício total de se consumir um bem ou serviço, incluindo tanto o benefício privado quanto qualquer benefício externo (HUBBARD; O’BRIEN, 1999, p. 195).
} 
Frank e Bernanke (2012, p. 298), no mesmo sentido, definem a externalidade como custos ou benefícios externos de uma atividade econômica, classificando como custo externo ou externalidade negativa o custo de uma atividade que recai sobre outras pessoas que não aquelas que desenvolvem a atividade; e benefício externo ou externalidade positiva como o benefício de uma atividade recebido por pessoas que não aquelas que exercem a atividade produtiva. Esses efeitos geralmente não são intencionais.

Reforçando o conceito de externalidade, Eaton e Eaton (1999) comentam que a externalidade na linguagem dos economistas ocorre sempre que o comportamento de um agente econômico afeta para melhor ou para pior o bem-estar de outro, o que origina a externalidade negativa e/ou positiva à pessoa afetada.

Assim, é consenso na literatura que as externalidades (ou efeitos sobre o exterior) são atividades que envolvem a imposição involuntária de custos ou de benefícios, isto é, que têm efeitos positivos ou negativos, sobre terceiros sem que estes tenham oportunidade de impedilo e sem que tenham a obrigação de pagá-los ou o direito de ser indenizados. A externalidade leva a resultados ineficientes do ponto de visa social, na medida em que os agentes não incorporam (não internalizam) todos os custos ou benefícios possíveis para a tomada de decisão, afirmam Eaton e Eaton (1999).

Importa destacar que as externalidades são geradoras de ineficiência dos mercados, pois, segundo Hubbard e O’Brien (1999, p. 197), “as externalidades e os fracassos de mercado resultam de direitos de propriedade incompletos ou de uma dificuldade em fazer cumprir os direitos de propriedade em certas situações”.

Frank e Bernanke (2012, p. 299) afirmam que "todas as atividades envolvem custos e benefícios e, quando todos os custos e benefícios relevantes de uma atividade recaem diretamente sobre a pessoa que a executa, a atividade não gera externalidade". Um mercado com externalidades permite a solução privada dos problemas dele decorrentes, uma delas seria "a fusão dos processos produtivos, onde problema de produção da empresa passa a considerar não apenas os benefícios gerados pela produção de poluição para o processo industrial, como também o custo para o processo extrativo" (CHAGAS, 2011, p. 284). 
Dentre as soluções para o problema da externalidade, está a solução pública, que é quando o governo intervém por meio de políticas públicas, afirmam Hubbard e O’Brien (2010). Já Frank e Bernanke (2012, p. 299) sustentam que, "quando uma atividade gera externalidade, o egoísmo individual não produz a melhor alocação dos recursos, ou seja, não importa se o efeito da externalidade é negativo ou positivo".

Importante consignar que definir os direitos de propriedade não é algo simples e trivial, já que haverá ganhadores e perdedores de um eventual processo de negociação, e requer a existência de órgãos de regulação e solução de conflitos nem sempre viáveis como empreendimentos privados, justificando a existência de um Estado regulador (CHAGAS, 2011).

A regulação estatal poderá ser feita limitando a produção de poluição por parte das empresas e/ou agentes poluidores, seja impondo um limite sobre quantidades, seja tributando a poluição gerada. Nesse último caso, a alíquota do imposto deveria ser fixada de modo a incentivar a indústria a reduzir a poluição. A fixação da tarifa ótima deve levar em conta os custos e benefícios sociais da poluição, o que conduz à mesma solução ótima do ponto de vista social. Esse tipo de imposto, que internaliza os efeitos de uma externalidade, é conhecido como Imposto de Pigou (CHAGAS, 2011).

Dado que, tal como referido e ao contrário das transações realizadas no mercado, as externalidades envolvem uma imposição involuntária, estas constituem uma ineficiência de mercado. Por isso é necessária a intervenção do Estado por meio da oferta ou da criação de incentivos à oferta de atividades que constituem externalidades positivas (por exemplo, subsidiando a investigação e o desenvolvimento ou oferecendo gratuitamente a iluminação pública) e por meio do impedimento ou da criação de incentivos à não produção de externalidades negativas (por exemplo, criando regulamentações para controlar a emissão de poluição das fábricas).

Em contraste com a visão tradicional, de inspiração pigouviana, pode-se antepor a visão de Coase, segundo a qual, outra forma de solução privada seria reduzir custos de transação de modo a permitir que as empresas negociem entre si a quantidade ideal de poluição. Aplicação direta do Teorema de Coase, esta solução considera que pode haver um grau de custos de transação que não impeça a negociação, a partir da definição de direitos de propriedade. Nesse sentido, retomando Coase (1960), que assentou a importância das instituições destacando o seu papel fundamental, recupera-se o conceito de custos de transação, os quais 
derivam das interações dinâmicas entre os agentes econômicos no mercado. $\mathrm{O}$ autor ainda desaconselha a intervenção do Estado nos casos em que os custos de transação superem os benefícios da própria atuação estatal, considerando que a eficiência é o conceito-chave neste caso, entendendo que cada conflito atende a uma das circunstâncias socioeconômicas particulares, e possibilitando uma brecha para negociação entre as partes afetadas em conflitos em torno de externalidades negativas.

Uma importante contribuição no que se refere ao fornecimento de bens públicos, e que reforça o importante papel do ambiente institucional quando o assunto são bens públicos, foi o trabalho de Coase $(1974)^{25}$, que apresentou sua visão fundamentada, não somente sob a ótica reguladora do Estado e dos mecanismos institucionais estatais, mas também considerando a possibilidade do fornecimento eficiente de bens públicos, por parte de agentes econômicos privados, os quais podem abastecer o mercado desse tipo de bens, de forma eficiente, gerando benefícios privados, a depender do ambiente institucional. Tal visão foi contrária à proposta por Samuelson, no exemplo da operação dos faróis de sinalização costeira. O ambiente institucional é o principal fundamento do autor em relação a bens públicos.

Até a publicação de Coase (1974), o mainstream da economia sobre bens públicos assentava que não podiam ser fornecidos adequadamente por mercados livres, e a intervenção do governo seria a única solução para o fornecimento desses bens à sociedade em quantidade eficiente. Por outro lado, a partir da publicação de Coase (1974), para desenvolver a produção de bens públicos não é sempre que se precisa da intervenção do Estado, trazendo à discussão a possibilidade da existência de um setor privado gerador de benefícios privados, e providente eficiente de bens públicos, a depender do desenho das instituições.

A importância das instituições reside no fato de estabelecerem as regras do jogo, quando regulam a atividade econômica, tanto como mecanismos regulatórios como supletivos do mercado, afirma Coase (1974). O autor ainda destaca que, no caso de regulação, tende-se a confundir com a construção institucional do mercado e, quando isto não for possível, as

\footnotetext{
${ }^{25}$ Em The lighthouse in Economics (1974), Coase abre a discussão sobre o fornecimento dos bens públicos, valorando seu estudo histórico do funcionamento privado e eficiente dos faróis na Grã-Bretanha durante os séculos XVII a XIX, contrariando o pensamento generalizado em economia, o qual se materializava em torno dos apontamentos de diversos autores, especialmente Paul Samuelson sobre a sistemática de provisão estatal dos bens públicos, trazendo como exemplo os faróis.
} 
instituições passam a funcionar como um supletivo do mercado, de forma que a produção possa ser produzida e consumida privadamente, ou seja, neste caso as instituições constituemse como um quase-mercado.

Coase (1974), ao questionar a sistemática obrigatoriedade da intervenção estatal diante das externalidades positivas, justifica a eficiência na provisão dos bens públicos, fundamentando suas conclusões na experiência empírica da gestão privada dos faróis da Grã-Bretanha durante os séculos XVII a XIX, quando a atividade foi desenvolvida proporcionando lucros privados. O autor justifica que a gestão dos faróis poderá ser desenvolvida eficientemente por agentes privados, como demonstra a tradição britânica; que é possível cobrar um preço de pedágio a cada um dos usuários dos faróis mediante um sistema de contribuições cobrados nos portos uma vez finalizada a viagem; que o papel do Estado está limitado a estabelecer os direitos de propriedade adequadamente; e invalida o exemplo dos faróis como um caso de bens públicos ${ }^{26}$.

Além da discussão sobre a existência de custos de transação como determinante do nível de intervenção estatal em uma economia que apresente externalidades, outro aspecto-chave, foi o da provisão dos bens públicos sobre a questão da impossibilidade de garantir a cobrança do serviço fornecido aos usuários. $\mathrm{O}$ autor observou que, no caso dos faróis, essa cobrança poderia ser realizada pelo sistema de pagamento articulado por agentes privados ou por customs officials, em que a base é um sistema de contribuições pelo uso de faróis nos portos. Esse sistema de pagamento seria mais eficiente do que o sistema de cobrança de imposto geral (COASE, 1974).

Dessa forma Coase (1974) assenta-se na ideia de que os faróis britânicos fossem geridos em regime de propriedade privada, e sob condições institucionais que fornecessem ao mercado as estruturas básicas de intercâmbio, limitando-se a estabelecer adequadamente os direitos de propriedade. Ademais, apoia-se na tradição do sistema britânico de faróis para enfatizar que é possível cobrar e arrecadar os valores derivados dos serviços prestados pelos faróis.

\footnotetext{
${ }^{26}$ Os faróis foram construídos, financiados por indivíduos privados e eram de propriedade deles, que podiam comercializar o serviço. O papel do governo estava limitado ao estabelecimento dos Direitos de Propriedade dos Faróis, a cobrança era arrecadada nos portos por agentes que atuavam por conta do Faróis. (COASE, 1974, p. $375)$.
} 
Portanto, o mercado só funcionará de forma eficiente com a presença de instituições fortalecidas e com baixos custos de custos de transação.

\subsubsection{As instituições e o ambiente institucional}

A nova economia institucional para Williamson (1996) opera em dois níveis relacionados: as instituições de governança (ou os jogadores) e o ambiente institucional (ou as regras do jogo). Para North (1990), as instituições são importantes para diminuir a incerteza e estabelecer uma base estável para as relações contratuais. Elas podem oferecer oportunidades para a sociedade em geral, e as organizações são criadas para tirar proveitos dessas oportunidades geradas pelo ambiente institucional ${ }^{27}$.

A análise de ambiente institucional tem sido realizada consoante dois procedimentos: investigar os efeitos de uma mudança no ambiente institucional sobre o resultado econômico e teorizar sobre a criação, a origem e a evolução das instituições. O primeiro tem se desenvolvido nos estudos voltados para a história econômica, revelando, por exemplo, evidências de que a existência de direitos de propriedade claramente definidos e o compromisso claro do Estado para que eles sejam cumpridos favorece os investimentos e o crescimento econômico. O segundo tem encontrado mais dificuldades em seu desenvolvimento, principalmente porque os pressupostos adotados têm sido os mesmos da economia neoclássica, ou seja, que a tecnologia, as dotações iniciais e as preferências definem os preços relativos das ações humanas, incluindo o oportunismo.

O principal papel das instituições ${ }^{28}$ - entendidas como as "regras do jogo", formais e informais, que estruturam a interação social, econômica e política - é restringir ações humanas. (NORTH, 1991) Essas regras são também desenvolvidas com o objetivo de reduzir

\footnotetext{
${ }^{27} \mathrm{O}$ ambiente institucional é baseado em regras políticas, sociais e legais fundamentais, que estabelecem a base para a produção, a troca e a distribuição. Regras que administram eleições, direito de propriedade e o direito de contrato são exemplos (...) O arranjo institucional é um arranjo entre unidades econômicas que administram o meio pelo qual tais unidade podem cooperar (...) ou podem fornecer um mecanismo que pode proporcionar uma mudança nas leis ou no direito de propriedade (WILLIAMSON, 1996, p. 103).

${ }^{28}$ Instituições são as regras do jogo, tanto as formais quanto as informais e também as suas características de eficácia. Juntas, definem a forma como o jogo deve ser jogado. As organizações são os jogadores. Elas são compostas de grupos de indivíduos que possuem o mesmo objetivo comum. Organizações econômicas são firmas, sindicatos, cooperativas etc.; organizações políticas são os partidos políticos, legislativo, órgãos regulatórios; organizações educacionais são universidades, escolas, centro de treinamento vocacional (NORTH,1991).
} 
incertezas no mercado e, portanto, os custos de transação. As instituições estabelecem incentivos e padrões das transações contratuais entre e intraorganizações. Segundo o autor, o papel das instituições está em organizar o ambiente de negócio, reduzir as incertezas e, em conjunto com outros instrumentos econômicos, definir um conjunto possível de escolhas, criando um ambiente favorável para o processo de tomada de decisão. Assim, as instituições fornecem uma estrutura de incentivos, contribuindo para o desempenho da economia, podendo influenciar a forma como a organização surge e se comporta, e afetam seus modelos de governança corporativa e desempenho (NORTH, 1990; WILLIAMSON, 1993).

A proposta de estudo das instituições dentro da Nova Economia Institucional é desenvolvida em dois níveis: o ambiente institucional e o arranjo institucional. $\mathrm{O}$ primeiro dirige-se à compreensão dos ambientes formal e informal nos quais se desenvolvem as relações econômicas em geral. O estudo dos arranjos institucionais, por sua vez, concentra-se na análise da escolha da estrutura de governança realizada pelos atores econômicos. Desse modo, enquanto o ambiente institucional propicia o conjunto de regras ou a estrutura na qual ocorre a produção, o comércio e a distribuição, os arranjos institucionais determinam o conjunto específico de relações funcionais entre os atores envolvidos.

Assim, a abordagem institucional envolve a análise conjunta de regras formais e informais relacionadas com direitos de propriedade, defesa da concorrência, meio ambiente e outros aspectos, que regulam a ação dos agentes, assim como as organizações instituídas para criar e aplicar essas regras e solucionar conflitos, como parlamentos, governos, tribunais e instâncias de arbitragem.

Parte da literatura neoinstitucionalista foca o ambiente institucional, buscando entender sua influência sobre, de um lado, o desempenho econômico e, de outro, o comportamento dos agentes econômicos. O trabalho de North (1990) adota primordialmente essa perspectiva, ou seja, analisa em que medida o desempenho comparado de diferentes países se relaciona com seu sucesso relativo em estabelecer instituições que salvaguardem tipos de transações em que a eficiência é muito aumentada com o uso de ativo específico.

Há outros trabalhos de Coase $(1960 ; 1974)$ e de Williamson (1996) cujo foco recai sobre os arranjos institucionais criados pelos próprios agentes econômicos para estruturar suas relações a fim de economizar em custos de transação. Em especial, a lei, os direitos contratuais e de 
propriedade servem de regras que ajudam a poupar em custos de transação, ou seja, reduzir a complexidade e, portanto, o custo de transação, fornecendo um conjunto de termos usuais, que, na ausência do direito contratual, as partes teriam de negociar; e, ainda fornece às partes potencialmente interessadas em uma transação informação sobre as muitas contingências que podem sensatamente impedir sua conclusão.

Existe, sim, complexidade para entendimento das normas ambientais. A falta de informação ecológica por parte dos cidadãos e a urgência de transformação comportamental, que ponha termo à degradação ambiental, bem como os instrumentos propostos pela análise econômica, sejam os impostos ambientais, ou ecoimpostos (visão pigouviana), que procuraram internalizar, no cálculo econômico empresarial, as externalidades negativas, a exemplo da negociação de licenças para poluir (COASE, 1960), traduzidas em direitos de poluir, e em quotas de emissão negociáveis, tornam as normas jurídicas cativas da ciência e da técnica normativa. Assim, as normas jurídicas podem assumir o papel de gestão do risco ambiental pela falta de conhecimento e interpretação à luz do ordenamento brasileiro.

As instituições estruturam incentivos que determinam a forma como as economias se desenvolverão. Se as instituições são restrições informais e regras do jogo da interação humana, consideram-se incluídas as organizações com finalidades específicas como aquelas atinentes ao meio ambiente ou serviços ambientais.

A natureza da relação entre instituições e desempenho econômico depende de saber como vão ser usadas as competências e os conhecimentos adquiridos pelas organizações; se forem usadas produtivamente a economia cresce; se forem usadas para atividade redistributiva a economia não cresce (NORTH, 1993, p. 243).

Por tudo isto há, no mundo, instituições. Elas formam-se para reduzir a incerteza na troca e são minimizadoras dos custos de transação; são meios pelos quais se superam as falhas de mercado.

\subsubsection{Código Florestal e os serviços ambientais}


No Brasil, discute-se a implantação do Código Florestal $^{29}$, que tem como um dos princípios a criação e a mobilização de incentivos econômicos para fomentar a preservação e a recuperação da vegetação nativa e para promover o desenvolvimento de atividades produtivas sustentáveis, além do destaque de regras para o consumo de bens ambientais, sempre com a preocupação da regulação do consumo de tais ativos.

A legislação ambiental tem concedido incentivos para o cumprimento das obrigações impostas, de forma a premiar aqueles cujas condutas são positivas ao meio ambiente e à própria sociedade. Se forem usadas produtivamente a economia cresce; se forem usadas para atividade redistributiva a economia não cresce (NORTH, 1993, p. 243).

Nesse contexto, o Código Florestal estabeleceu vários princípios, a começar pela manutenção da preservação das florestas e das demais formas de vegetação nativa; outros princípios foram a função estratégica da atividade agropecuária e das florestas e demais formas de vegetação nativa na sustentabilidade, no crescimento econômico, na melhoria da qualidade de vida da população brasileira e na presença do País nos mercados nacional e internacional de alimentos e bioenergia; a criação de políticas para a preservação e restauração da vegetação nativa e de suas funções ecológicas e sociais nas áreas urbanas e rurais; o fomento à pesquisa científica e tecnológica na busca da inovação para o uso sustentável do solo e da água; a recuperação e a preservação das florestas e demais formas de vegetação nativa; e a criação e a mobilização de incentivos econômicos para fomentar a preservação e a recuperação da vegetação nativa e promover o desenvolvimento de atividades produtivas sustentáveis.

O Poder Executivo federal foi autorizado a instituir, sem prejuízo do cumprimento da legislação ambiental, programas de apoio e incentivo à conservação do meio ambiente, bem como para adoção de tecnologias e boas práticas que conciliem a produtividade agropecuária e florestal, com redução dos impactos ambientais, como forma de promoção do desenvolvimento ecologicamente sustentável, observados sempre os critérios de progressividade.

Dentre os principais incentivos, destacam-se a criação da Cota de Reserva Ambiental, um

\footnotetext{
${ }^{29}{ }^{2}$ ei $^{\circ}{ }^{\circ} 12.651$, (BRASIL, 2012): Dispõe sobre a proteção da vegetação nativa; altera as Leis $\mathrm{n}^{\text {os }} 6.938$, de 31 de agosto de 1981, 9.393, de 19 de dezembro de 1996, e 11.428, de 22 de dezembro de 2006; revoga as Leis $\mathrm{n}^{\text {os }}$ 4.771, de 15 de setembro de 1965, e 7.754, de 14 de abril de 1989, e a Medida Provisória nº 2.166-67, de 24 de agosto de 2001; e dá outras providências.
} 
título nominativo representativo de área com vegetação nativa, existente ou em processo de recuperação, caracterizada como Servidão Ambiental; a Reserva Legal instituída voluntariamente sobre a vegetação que exceder os percentuais legais; a Reserva Particular do Patrimônio Natural, ou localizada no interior de Unidade de Conservação de domínio público que ainda não tenha sido desapropriada.

O Novo Código Florestal prevê a possibilidade da transferência, onerosa ou gratuita, para pessoa física ou pessoa jurídica de direito público ou privado, mediante termo assinado pelo titular da CRA e pelo adquirente. Nesse cenário, instrumentos têm sido idealizados no país para dinamizar a utilização da CRA, como a Bolsa Verde do Rio de Janeiro ${ }^{30}$, plataforma eletrônica de comércio de títulos de reserva ambiental, inaugurada recentemente.

Portanto, essas ações, regras e culturas resultam de ideias que produzem materiais concretos que são usados com múltiplas finalidades - a troca, a produção, a satisfação -, isso porque, as instituições são frutos da experiência contendo mudanças para evolução do indivíduo e da sociedade.

\subsubsection{C Código Florestal e sua relação com o mercado de serviços ambientais}

Os serviços ambientais prestados pelas florestas incluem a melhoria da qualidade do ar (por meio da neutralização de gases causadores do efeito estufa, como o $\mathrm{CO} 2$ ), da água, do solo e a preservação da biodiversidade e dos recursos genéticos (usados na agricultura, na medicina, na indústria de cosméticos entre outros). Os pagamentos por serviços ambientais são uma fórmula de compensação financeira que vem sendo aplicada para que áreas de florestas sejam mantidas e recompostas. Estes foram incluídos no Novo Código Florestal para garantir os incentivos à preservação das áreas de reserva legal (RLs) e de preservação permanente (APPs) nos imóveis rurais. Ou seja, é considerado um instrumento econômico que visa à conservação ambiental, baseando-se na lógica do provedor-receptor. Está fundamentado na modificação das atitudes individuais por meio de incentivos econômicos, pelos quais aquele que se compromete a manter o fornecimento de um serviço ambiental é compensado

\footnotetext{
${ }^{30}$ BOLSA VERDE RIO DE JANEIRO. Disponível em: < http://www.bvrio.org/site/ > . Acesso em: 30 mar. 2014.
} 
monetariamente.

Impende salientar que a necessidade da aplicação desse tipo de mecanismo se deve ao fato de que, por mais que a legislação seja explícita ao garantir no art. 225 da Constituição Federal (BRASIL, 1988) que "Todos têm direito ao meio ambiente ecologicamente equilibrado, bem de uso comum do povo e essencial à sadia qualidade de vida, impondo-se ao poder público e à coletividade o dever de defendê-lo e preservá-lo para as presentes e futuras gerações", muitas pessoas ainda não reconhecem a real importância da preservação dos recursos naturais que garantem os serviços ambientais, e dessa forma usufruem destes de maneira extremamente individualista e a curto prazo.

Além disso, a fiscalização para o que está previsto na legislação é aquém do necessário para garantir a qualidade ambiental. Deste modo, o Pagamento por Serviços Ambientais se mostra como uma alternativa a fim de solucionar este impasse.

Além disso, a fiscalização para o que está previsto na legislação é aquém do necessário para garantir a qualidade ambiental. Desse modo, o Pagamento por Serviços Ambientais mostra-se como uma alternativa a fim de solucionar esse impasse.

Percebe-se que o Novo Código Florestal, inspirado nos moldes dos instrumentos de comando e controle, prejudica sua eficiência e sua finalidade última diante da realidade atual. Fato ,que demonstra o não acompanhamento da referida legislação às transformações e ao dinamismo provocado pela busca constante de institutos apropriados para estabelecer-se uma política adequada e efetiva, objetivando a conservação de bens naturais, culturais, paisagísticos, históricos, entre outros, para o uso desta e das futuras gerações.

É nesse sentido a previsão da criação do programa de apoio e incentivo à conservação do meio ambiente, bem como para adoção de tecnologias e boas práticas que conciliem a produtividade agropecuária e florestal, com redução dos impactos ambientais, como forma de promoção do desenvolvimento ecologicamente sustentável, observados sempre os critérios de progressividade, abrangendo as seguintes categorias e linhas de ação: pagamento ou incentivo a serviços ambientais como retribuição, monetária ou não, às atividades de conservação e melhoria dos ecossistemas e que gerem serviços ambientais, tais como, isolada ou cumulativamente, o sequestro, a conservação, a manutenção e o aumento do estoque e a diminuição do fluxo de carbono; a conservação da beleza cênica natural; a conservação da 
biodiversidade; a conservação das águas e dos serviços hídricos; a regulação do clima; a valorização cultural e do conhecimento tradicional ecossistêmico; a conservação e o melhoramento do solo e a manutenção de Áreas de Preservação Permanente, de Reserva Legal e de uso restrito.

Portanto, cuidou o Novo Código Florestal de eleger as atividades de manutenção das Áreas de Preservação Permanente, de Reserva Legal e de uso restrito, para quaisquer pagamentos ou incentivos por serviços ambientais, configurando adicionalidade para fins de mercados nacionais e internacionais de reduções de emissões certificadas de gases de efeito estufa. E, ainda, o programa relativo a serviços ambientais deverá integrar os sistemas em âmbito nacional e estadual, objetivando a criação de um mercado de serviços ambientais.

\subsubsection{Arranjo institucional}

Arranjos representam o suporte e a forma que governam suas unidades econômicas, indivíduos ou grupos que estruturam sua cooperação ou concorrência de modo a assegurar as transações que permitam vantagem da divisão de trabalho e de especialização (estruturas de governança.

Os arranjos institucionais ou mecanismos de governança é o modo organizacional e referemse ao modo pelo qual os agentes estruturam suas atividades de produção e de trocas dentro de um quadro de regras definidas pelas instituições.

WILLIAMSON (1996) conceitua arranjo institucional como sendo aquele entre as unidades econômicas que administram o meio pelo qual tais unidades podem cooperar, ou podem fornecer um mecanismo que podem proporcionar uma mudança nas leis ou no direito de propriedade.

O foco de estudo da Teoria do Custo de Transação é entender como se formam as medidas de salvaguardas, e o que acontece quando elas não são viáveis. As leis e o judiciário são a principal salvaguarda de que se dispõe, mas não são as únicas. Exemplifica-se. Pode-se criar uma agência reguladora que se responsabilize por arbitrar as disputas entre as partes, com 
base em objetivos próprios (em geral, evitar a expropriação de uma das partes pela outra, sobreviver uma situação não prevista no contrato original). Há também salvaguardas que podem ser incluídas no próprio contrato com garantias reais em caso de inadimplência ou limites às atividades que possam ser desenvolvidas pelos agentes.

E, ainda, pode haver um processo de internalização da transação, com vistas a que ela seja realizada dentro de uma organização. Neste caso, o investimento em ativos específicos estaria protegido do oportunismo, uma vez que só uma parte desses ativos poderia estar sujeita à regulação, quando integrante do mercado. De acordo com esse exemplo, a organização nada mais é do que um arranjo institucional com salvaguardas implícitas, resultante do fato de que todos os ativos têm o mesmo dono, o que elimina o oportunismo.

Esse é o princípio de Coase (1937) sobre a natureza da firma, em que ele observou que não apenas a tecnologia, como também o objetivo de economizar custos de transação, determinava a fronteira que separa as transações feitas dentro da firma, e aquelas fora dela, por intermédio do mercado. Dessa maneira, o mercado e a firma passaram a ser vistos como meios alternativos de se organizarem as transações econômicas, com preferência por uma ou por outra ditada pelos custos de produção e transação. Se os custos de transação são mais baixos quando se realiza a transação sobre uma estrutura hierárquica, ela é localizada dentro da organização; se, pelo contrário, a transação pode ser feita a baixo custo, por meio de uma relação relativamente anônima, como as que ocorrem no mercado, é lá que ela deve estar. Ou seja, a firma nada mais é do que um feixe de contratos, interno à firma, porque essa é a melhor forma de reduzir os custos de transação.

Portanto, os custos de transação em uma alternativa e outra dependem diretamente de instituições como a lei e, portanto, a fronteira ótima da firma, e de modo particular os arranjos institucionais complexos - em que se consolidam as transações que custam quase o mesmo se realizadas dentro ou fora -, pode variar de uma jurisdição para outra, ou de uma época para outra em uma mesma jurisdição.

Em relação aos arranjos institucionais, ainda que também dependam da estrutura legal, há uma forte influência do que Williamson (1996) denomina de ordenamento privado - isto é, regras e práticas infralegais ou mesmo informais que incentivam a correta execução de contratos. Mecanismo de reputação, participações acionárias cruzadas e investimentos realizados por ambas as partes em ativos específicos são exemplos de arranjos institucionais. 
O estudo dos contratos tem sido uma vertente essencial ao longo da evolução da Economia dos Custos de Transação (ECT), em razão do reconhecimento de sua função de como governar as transações. Considerados de forma ampla, eles representam os mais variados acordos entre os agentes, podendo aparecer entre firmas no mercado, como uma simples transação de compra e venda, ou dentro das firmas, como um contrato de trabalho.

Zylbersztajn (1995) destaca o estudo das relações contratuais como uma das principais áreas da Nova Economia Institucional (NEI), da qual a ECT faz parte, que envolve outras áreas, como Economia, Direito e Administração, ainda que estas tenham enfoques diferentes sobre os contratos.

Explica o autor: a Economia considera os aspectos ligados à eficiência, enquanto para o Direito o critério de avaliação dos contratos seria a justiça. E, ainda, relaciona os seguintes aspectos dos contratos:

a) Incompletude: característica fundamental de qualquer contrato, deriva da impossibilidade de se preverem eventos ou comportamentos futuros, assim como da racionalidade limitada dos agentes, que seriam incapazes de considerar todos os aspectos relevantes das transações envolvidas. O desenvolvimento de uma teoria dos contratos deve contemplar regras para o preenchimento das lacunas inevitáveis dos contratos.

b) Custos: relativos à negociação, elaboração, monitoramento, criação e aplicação de mecanismos para a solução de conflitos e para a punição de comportamentos indesejados. Uma das formas encontradas pela sociedade para reduzir os custos na solução de conflitos foi a criação de instituições estruturadas para esse fim, como tribunais formais ou informais. A firma pode ser considerada uma estrutura apta a resolver uma parcela significativa das disputas, por meio da hierarquia.

c) Duração: concebidos em geral com prazo indeterminado, os contratos podem ser temporários a priori ou ter a duração interrompida por quebras contratuais unilaterais ou novas etapas de negociação. A presença de ativos específicos gera a necessidade de compromissos com prazos mais longos, suficientes para que se recupere o investimento realizado.

Para o contrato clássico, característico das relações de mercado, o preço é determinante. 
Nesses contratos, cláusulas formais especificam a maioria das características da transação em questão, sendo irrelevante a identidade dos participantes, e as transações são altamente monetizadas. Entre os dois arranjos estão os contratos neoclássicos, característicos das formas híbridas, em que os preços têm um papel importante de ajustamento, que é limitado pela presença de ativos específicos, e as salvaguardas são de difícil implementação.

O contrato neoclássico é tipicamente um arranjo de longo prazo, cujo objetivo é desenvolver um relacionamento continuado, no qual a identidade dos agentes é importante em virtude da existência de dependência bilateral, enquanto os mecanismos de ajustamento devem ser flexíveis o suficiente para permitir que as partes se adaptem a distúrbios de impacto moderado.

Portanto, o contrato é instituto intimamente ligado às relações econômicas, pois é seu instrumento de operacionalização, e a forma pela qual é regulado pode dar maior ou menor efetividade às relações econômicas, podendo otimizar os enlaces suficientes ou reprovar as relações viciadas. A análise econômica do contrato é indispensável para o modelo de mercado e do direito de propriedade, constituindo arranjos institucionais que demandam regras claras para sua execução.

\subsection{Bens e serviços ambientais}

No presente subcapítulo, o objetivo é apresentar a revisão de literatura e contribuições existentes acerca do assunto bens e serviços ambientais, com o intuito de obter informações e conhecimentos que contribuirão para a formação do suporte teórico que fundamentará a resposta aos objetivos da pesquisa.

\subsubsection{Dos bens ambientais}


A Constituição Federal (BRASIL, 1988), art. 225 $5^{31}$, em seu capítulo VI do Título VIII sobre a Ordem Social, inovou em relação às cartas magnas anteriores, pois, além de autorizar a tutela de direitos individuais, o que tradicionalmente já era feito, passou a admitir a tutela de direitos coletivos, porque compreendeu a existência de uma terceira espécie de bem: o bem ambiental.

A definição de bens é importante para o estudo, especialmente, na distinção entre bens públicos e bens privados. Os bens públicos são aqueles que possuem as características de não rivalidade no consumo - o consumo de um não diminui a possibilidade de consumo por outro -, e de não exclusão - uma vez produzido, é impossível (ou muito difícil) evitar que se tenha acesso a ele. Os bens privados tendem a ser exclusivos e/ou rivais no consumo ou na produção, e sua propriedade pode ser transferida ou negada sob a condição geradora de troca, ou seja, o pagamento de seu preço (KAUL; GRUNBERG ; STERN, 2012).

Em uma concepção jurídica, De Plácido e Silva (2004, p. 218) definem "bens públicos como sendo aqueles de uso comum e pertencentes ao domínio particular do Estado, que em sentido lato são os bens destinados ao uso e gozo do povo". Os bens privados, em contraponto aos bens públicos, são aqueles bens que têm uso reservado aos interesses de seu proprietário, e são tidos na acepção de bens destinados a certos fins (DE PLÁCIDO E SILVA, 2004, p. 217).

Fiorillo (2008) define bem ambiental como sendo um bem de uso comum do povo, podendo ser desfrutado por toda e qualquer pessoa dentro dos limites constitucionais, e, ainda, um bem essencial à qualidade de vida, sendo classificado como bem de uso comum ao povo, essencial à sadia qualidade de vida. Assim, pode-se afirmar que o bem ambiental são a água, o ar, a flora a fauna, entre outros recursos disponíveis na natureza, para ser usufruído pelo homem (MILARÉ, 2007).

A Constituição (BRASIL, 1988), artigo 225, ao tratar de meio ambiente, formulou inovação no sentido de criar um terceiro gênero de bem que, em face de sua natureza jurídica, não se confunde com os bens públicos e muito menos com os bens privados. Daí pode-se reiterar a visão desse dispositivo constitucional, ao estabelecer a existência jurídica de um bem que se estrutura como sendo de uso comum do povo e essencial à sadia qualidade de vida,

\footnotetext{
${ }^{31}$ Art. 225. Todos têm direito ao meio ambiente ecologicamente equilibrado, bem de uso comum do povo e essencial à sadia qualidade de vida, impondo-se ao Poder Público e à coletividade o dever de defendê-lo e preservá-lo para as presentes e futuras gerações.
} 
configurando uma nova realidade jurídica e disciplinando bem que não é público nem, muito menos, privado.

A autora portuguesa Garcia (2007) esclarece que o sentido holístico do meio ambiente veio trazer um sentido novo aos bens ambientais, porquanto aliou à ideia tradicional de bens insuscetíveis de apropriação, como a pureza do ar ou a biodiversidade, uma pretensão individual idêntica para todos quantos habitam o planeta ou irão habitar no futuro, e que não só torna esses bens, em certo sentido, apropriáveis como os agrupa amplamente numa peça unitária a que se chama patrimônio comum da humanidade.

Por sua vez, os bens ambientais aproximam-se da concepção de interesse difuso. Para Fiorillo (2008), o direito difuso apresenta-se como um direito transindividual, tendo um objeto indivisível, titularidade indeterminada e interligada por circunstância de fato. Assim, a titularidade na defesa de um direito é estendida a todas as pessoas, que, de forma direta ou indireta, tenham sido afetadas por um abalo de direito, provocado por agente da própria sociedade. Dessa forma, os bens ambientais são de interesse difuso, em face de sua indispensabilidade à manutenção da qualidade ambiental.

Dessas disposições constitucionais, ainda, pode-se afirmar que existem três conjuntos de normas relacionadas à proteção ambiental. A primeira é onde se inscreve a norma-princípio, a norma-matriz, substancialmente reveladora do direito de todos ao meio ambiente ecologicamente equilibrado. A segunda institui os instrumentos de garantia da efetividade do direito ambiental. A terceira, finalmente, caracteriza um conjunto de determinações particulares, em relação a objetos e setores, nos quais a incidência do princípio constitucional se revela de primordial exigência e urgência, dado que são elementos sensíveis que requerem imediata proteção e direta regulamentação constitucional, a fim de que sua utilização, necessária talvez ao progresso, se faça sem prejuízo ao meio ambiente.

Por sua vez, o meio ambiente é a interação do conjunto de elementos naturais, artificiais e culturais que propiciam o desenvolvimento equilibrado da vida em todas as suas formas. A integração busca assumir concepção unitária do ambiente, compreensiva dos recursos naturais e culturais. O legislador infraconstitucional brasileiro tratou de definir o meio ambiente como sendo "o conjunto de condições, leis, influências e interações de ordem física, química e biológica, que permite, abriga e rege a vida em todas as suas formas" (BRASIL, 1981). O 
meio ambiente oferece à sociedade uma infinidade de serviços e produtos em nível local, regional, nacional e mundial. Esses bens e serviços ofertados possuem impactos significativos sobre a economia e o bem-estar da sociedade.

Com o intuito de facilitar a identificação da atividade degradante bem como o bem imediatamente agredido, vários autores classificam o meio ambiente em: meio ambiente natural, que é constituído pela atmosfera, pelos elementos da biosfera, pelas águas (inclusive pelo mar territorial), pelo solo, pelo subsolo (inclusive recursos minerais), pela fauna e flora; meio ambiente artificial, que é compreendido pelo espaço urbano construído, consistente no conjunto de edificações (chamado de espaço urbano fechado), e pelos equipamentos públicos (espaço urbano aberto); e, meio ambiente cultural, que é integrado pelo patrimônio histórico, artístico, que embora artificial, em regra, como obra do homem, difere do meio ambiente artificial pelo sentido de valor especial que adquiriu ou de que se impregnou.

Portanto, somente com a Constituição Federal (BRASIL, 1988), fruto do movimento ambientalista houve a definição de um bem ambiental, não considerado público e muito menos privado, constituído pelo complexo de recursos naturais na formação do ecossistema indispensável à vida terrestre, levando o legislador a conscientizar-se da necessidade de criar normas de proteção efetivamente ambientais, ou seja, com o objetivo de proteger o ecossistema em si, e não uma atividade econômica deste dependente.

\subsubsection{Dos serviços ambientais}

Várias são as definições para o termo serviços ambientais na literatura especializada, podendo ser identificado também como serviços ecossistêmicos ou ainda serviços ecológicos.

Swallow et al (2007) defendem que o termo serviços ambientais seja utilizado como gerador de benefícios recebidos do meio ambiente e percebidos pelas pessoas. O benefício gerado é percebido quando uma atividade econômica em determinado lugar é controlada por agentes econômicos, com efeitos positivos sobre outros consumidores ou produtores em outros lugares. Já os serviços ecossistêmicos, também segundo Swallow et al (2007), estariam focados nos processos pelos quais o meio ambiente produz recursos que usualmente são 
tomados como bens gratuitos, tais como água limpa, madeira, habitat para peixes e polinização de plantas nativas ou agrícolas. Os serviços ecossistêmicos representam os benefícios que as populações humanas auferem, direta ou indiretamente, das funções ecossistêmicas (CONSTANZA et al, 1997).

Apesar da discussão na literatura acerca da utilização do termo "serviços ambientais" ou "serviços ecossistêmicos", assumindo uma natureza separável de serviços diferentes, o termo "serviços ambientais" provavelmente tem uma interpretação mais integral, o que implica que os serviços múltiplos nem sempre podem ser divididos em componentes aditivos (SCHERR; KHARE; WHITE, 2004 apud WUNDER, 2005).

Wunder (2005) entende que os serviços ambientais se refiram a um dos muitos prestados pelos ecossistemas tais como serviços de água, conservação da biodiversidade e sequestro de carbono, enquanto serviços ecossistêmicos seriam utilizados por aqueles que alegam não ser possível separar em partes diversos serviços, os quais deveriam ser vistos de forma integrada. Na opinião de Heal (2000), os serviços ambientais são os responsáveis pela infraestrutura necessária para o estabelecimento das sociedades humanas, sendo caracterizados pela capacidade de a natureza garantir que a vida possa ocorrer sem maiores custos e com qualidade de vida para a sociedade. Para Born e Talocchi (2002), o termo serviços ambientais é entendido como benefícios indiretos gerados pelos recursos naturais ou pelas propriedades ecossistêmicas das inter-relações entre recursos na natureza, ou seja, o fluxo dos serviços que são indiretamente gerados por um recurso ambiental e pelos ecossistemas por meio de cada um do seu ciclo natural de existência. O autor, ainda, considera esses serviços como externalidades positivas geradas pela manutenção ou incremento da qualidade ou quantidade de recursos ambientais e serviços ambientais. Como exemplo, o autor apresenta produção e disponibilidade de água potável; regulação do clima; fertilidade do solo; biodiversidade atual ou potencial futura; e paisagem.

Numa definição mais abrangente, Daily (1997) estabelece que serviços ecossistêmicos são as condições e os processos por meio dos quais os ecossistemas naturais e as espécies que o formam sustentam e satisfazem a vida humana, mantendo a diversidade e a produção dos bens ecossistêmicos, na sustentação e no preenchimento das condições para a permanência da vida humana na Terra. Exemplifica o autor com os seguintes serviços ambientais: a purificação do ar e da água; a mitigação das enchentes e da seca; a desintoxicação e a decomposição dos 
dejetos; a geração e a renovação do solo e de sua fertilidade; a polinização das culturas e da vegetação natural; o controle da maioria das potenciais pragas agrícolas; a dispersão das sementes e a translocação dos nutrientes; a manutenção da biodiversidade, da qual depende a humanidade para sua alimentação, seus medicamentos e para o desenvolvimento industrial; a proteção contra os raios ultravioleta; a participação na estabilização do clima; o suporte para as diversas culturas da civilização humana; e o estímulo estético e intelectual para o espírito humano.

Uma das definições mais utilizadas é aquela dada pelo Millennium Ecosystem Assessment ${ }^{32}$ (Avaliação Ecossistêmica do Milênio), programa internacional das Nações Unidas. Para esse programa, os serviços ambientais são os benefícios que as pessoas obtêm dos ecossistemas, incluindo-se serviços funcionais prestados pelos ecossistemas, como os de provisão - os produtos obtidos diretamente dos ecossistemas tais como água e alimentos -; os de regulação - tidos como controle de processos ecossistêmicos, por exemplo controle de pragas e de enchentes; os culturais - tidos como benefícios não materiais como cultura e espiritualidade; e os de suporte - necessários para a manutenção de todos os outros serviços.

Para a OCDE, bens e serviços ambientais são aqueles que tenham por finalidade "medir, prevenir limitar, minimizar ou corrigir danos ambientais à água, ao ar e ao solo, bem como os problemas relacionados ao desperdício, à poluição sonora e aos danos aos ecossistemas". A OCDE elaborou uma lista com 164 bens ambientais que são utilizados para suprir um serviço ambiental, dentre os quais tratamento de água e esgoto, eliminação de lixo, aprimoramento e racionalização da utilização dos recursos naturais (MIRANDA; OLIVA, 2005).

As definições apresentadas pelos autores abordam os serviços ambientais com particularidades, sem contudo deixar de contemplar que a expressão serviços ambientais se refere aos bens e serviços prestados pelos sistemas vivos, tais como as florestas, os oceanos, assim como o meio ambiente como um todo, proporcionando ao homem um conjunto de benefícios tais como produção e fornecimento de oxigênio, sequestro de carbono, belezas cênicas, proteção de solos e regulação das funções hídricas, condições indispensáveis a sobrevivência do ser humano no planeta Terra. Dessa forma, o estudo vai utilizar como conceito dos serviços ambientais os benefícios que as pessoas obtêm dos ecossistemas

\footnotetext{
${ }^{32}$ ECOSYSTEM ENVIRONMENTAL ASSESSMENT. Disponível em:

$<$ http://www.milleniumassessment.org $>$. Acesso em: 15 jan. 2013.
} 
(sistemas vivos), proporcionando condições indispensáveis à permanência da vida humana na Terra.

Não se pode deixar de levar em consideração um fator importante a ser destacado, em uma discussão acerca de serviços ambientais, que é a determinação do valor econômico de um recurso ambiental, estimando um valor monetário deste em relação aos outros bens e serviços disponíveis na economia. Esse tema merece atenção especial quando se pensa no surgimento de mercado para os serviços ambientais, fator determinante para a negociação. Para Fearnside (1997), quando se pensa no mercado de serviços ambientais, principalmente os relacionados a água, mitigação de mudanças climáticas e biodiversidade, seu custo de manutenção é muitas vezes menor do que a potencial disposição de seus beneficiários em pagar por esses serviços. Da mesma forma, os produtos ambientais, entendidos como os produtos (produção de alimentos, insumos produtivos) oferecidos pelos ecossistemas, são utilizados pela sociedade para seu consumo presente, futuro ou para serem comercializados no mercado.

Portanto, pela relevância da produção dos serviços ambientais e por seu consumo, surge o conceito de pagamento por serviços ambientais (PSA), que tem recebido interesse da comunidade internacional nos últimos anos, como uma forma de criar medidas de incentivo para a gestão de recursos naturais.

\subsection{Pagamento por serviços ambientais e as concepções de mercado de serviços} ambientais

No presente subcapítulo, o objetivo é apresentar a revisão de literatura e contribuições existentes acerca do assunto pagamento por serviços ambientais e as concepções embrionárias acerca de mercado para esses serviços. O intuito é obter informações e conhecimentos que contribuirão para a formação do suporte teórico que fundamentará a resposta aos objetivos da pesquisa.

\subsubsection{Do pagamento por serviços ambientais}


A cobrança ou Pagamento por Serviços Ambientais (PSA) tem sido apontado como um mecanismo eficaz para proteção de áreas naturais e promoção do desenvolvimento local. Embora seja desejável, não se tem resolvido o impasse de gerar as condições necessárias para que os mercados funcionem de forma espontânea. A pergunta central é, se existe claro interesse social para o estabelecimento de mercados de serviços ambientais, por que tais mercados não se estabelecem espontaneamente?

Desde a Rio 92, o PSA é a proposta inovadora mais promissora visando à conservação do meio ambiente. Apesar das várias iniciativas em curso, os modelos e casos de PSA ainda precisam ser experimentados em uma escala e em diferentes condições, para que seja possível seu aperfeiçoamento e sua evolução (WUNDER, 2005).

A Organização das Nações Unidas para a Agricultura e Alimentação (FAO) publicou relatório em 2008, em que defende o PSA como a principal maneira de evitar a pressão da agricultura, que tende a aumentar cada vez mais sobre as áreas de florestas. Para discussão do tema, é fundamental estabelecer o marco conceitual do termo PSA.

A definição de PSA proposta por Wunder (2005), a partir de trabalho de campo na Bolívia e no Vietnã foi estruturada a partir de cinco princípios: deve ser uma transação voluntária; deve ser um serviço ambiental bem definido (ou um tipo de uso da terra que assegura esse serviço); deve ser comprado por ao menos um comprador dos serviços; deve ter pelo menos um provedor dos serviços; o provedor do serviço (ofertante) deve assegurar a prestação do serviço ambiental prestado.

A caracterização de cada um dos princípios defendidos pelo autor é condição para identificação de um PSA, conforme demonstrado no Quadro 2.

Quadro 2 - Critérios para identificação de PSA

\begin{tabular}{|c|l|}
\hline Critério de PSA & \multicolumn{1}{c|}{ Característica do critério de PSA } \\
\hline $\begin{array}{c}\text { Critério 1 - Deve ser uma } \\
\text { transação voluntária }\end{array}$ & $\begin{array}{l}\text { - Um quadro voluntário e negociado diferencia-se das medidas de comando e } \\
\text { controle. } \\
\text { - Provedores de serviços ambientais têm opções em potencial para uso da terra }\end{array}$ \\
\hline $\begin{array}{c}\text { Critério 2 - Serviço } \\
\text { ambiental bem definido }\end{array}$ & $\begin{array}{l}\text { - Deve ser diretamente mensurável }{ }^{33} \text { (por exemplo, toneladas adicionais de } \\
\text { carbono armazenado, ou o uso das camadas da terra que são suscetíveis de ajudar } \\
\text { na prestação desse serviço, ou a conservação da floresta fornece água limpa). }\end{array}$ \\
\hline
\end{tabular}

\footnotetext{
${ }^{33}$ Para funcionalidade do mercado dos serviços ambientais, a mensuração deve estar vinculada à redução de custos de transação.
} 


\begin{tabular}{|c|c|}
\hline & $\begin{array}{l}\text { - Disponibilidade de base de conhecimento para classificar objetivamente que } \\
\text { casos de prestação do serviço ambiental sejam reais. } \\
\text { - Quanto menos realista a base científica de um esquema de PSA, mais expostos } \\
\text { estão os riscos de compradores questionarem sua lógica e abandonar os } \\
\text { programas. }\end{array}$ \\
\hline $\begin{array}{l}\text { Critérios } 3 \text { e } 4 \text { - Existência } \\
\text { de no mínimo um } \\
\text { comprador e um vendedor }\end{array}$ & $\begin{array}{l}\text { - Deve haver recursos que vão de pelo menos um comprador }{ }^{34} \text { para o serviço } \\
\text { ambiental para ser transferido para, pelo menos, um fornecedor do serviço. } \\
\text { - A transferência de recursos ocorre muitas vezes por meio de um intermediário. }\end{array}$ \\
\hline $\begin{array}{l}\text { Critério } 5 \text { - Efetiva } \\
\text { prestação do serviço } \\
\text { ambiental }\end{array}$ & $\begin{array}{l}\text { - Os pagamentos determinados nos programas só devem ser realizados se aos } \\
\text { compradores de serviços tenham assegurado a efetiva prestação de serviços pelo } \\
\text { vendedor. } \\
\text { - Contratos de PSA devem ser flexíveis para que os compradores possam retirar- } \\
\text { se quando não constada a efetiva prestação de serviços. }\end{array}$ \\
\hline
\end{tabular}

Os critérios enumerados para o mercado de PSA divergem, em determinados pontos, de um mercado qualquer organizado para outros produtos e serviços. Primeiro, a definição sugere a necessidade de no mínimo um comprador e um vendedor; enquanto nos mercados tradicionalmente se consideram vários vendedores e compradores transacionando entre si. Segundo, a transferência de recursos ocorre muitas vezes por meio de um intermediário; em um mercado qualquer, a transferência ocorre de forma direta. Terceiro, quem paga pelos serviços ambientais não são os beneficiários; em um mercado qualquer, quem paga pelos produtos e serviços, diretamente, pode ser o beneficiário. Essas considerações levam a pensar que os, assim chamados, mercados de serviços ambientais se aproximam mais dos chamados arranjos institucionais complexos, e menos dos mercados concorrenciais. Espera-se, portanto, que se desenvolvam com base em contratos envolvendo um número limitado de agentes.

Os termos utilizados para descrever o mecanismo de remuneração nos PSA - pagamentos, mercados, recompensas e compensações - estão resumidos no Quadro 3.

Quadro 3 - Termos definidores de PSA

\begin{tabular}{|c|l|}
\hline \multicolumn{1}{|c|}{ Termos } & \multicolumn{1}{c|}{ Característica do critério de PSA } \\
\hline \multirow{3}{*}{ Pagamentos de serviços ambientais } & $\begin{array}{l}\text { - Termo mais genérico } \\
\text { - Associação monetária } \\
\text { - Pode aumentar a resistência ideológica } \\
\text { - Visto localmente como a opção de pagamento em espécie. }\end{array}$ \\
\hline \multirow{2}{*}{ Mercados para serviços ambientais } & $\begin{array}{l}\text { - Papel primordial de incentivos econômicos } \\
\text { concorrência em algum grau. }\end{array}$ \\
\hline Recompensas para serviços ambientais & $\begin{array}{l}\text { - Terminologia com implicação de direito e justiça para os } \\
\text { prestadores de serviços a serem garantidos por meio de uma } \\
\text { transação. } \\
\text { - Todo indivíduo que oferece benefício deve ser recompensado. }\end{array}$ \\
\hline
\end{tabular}

\footnotetext{
${ }^{34}$ Os compradores de serviços ambientais podem ser classificados em privados e públicos. Aqueles são financiados diretamente pelos usuários dos serviços; e estes, onde o Estado atua como comprador representando os usuários de serviços, são financiados com recursos públicos (WUNDER et al, 2009, p. 18).
} 


\begin{tabular}{|l|l|}
\hline & $\begin{array}{l}\text { - Termo que gera expectativas excessivas, já que os serviços não } \\
\text { são avaliados por altos valores, ou gera ameaças de falta de } \\
\text { compradores. }\end{array}$ \\
\hline \multirow{2}{*}{ Compensações por serviços ambientais } & $\begin{array}{l}\text { - Refere-se a um custo direto ou oportunidade, em nome do } \\
\text { prestador de serviços. } \\
\text { - Restringe o escopo para aqueles que suportam alguns custos. }\end{array}$ \\
\hline
\end{tabular}

Da análise do quadro 3, depreende-se que a existência e identificação de um PSA estão ligadas à possibilidade de pagamento pelos serviços ambientais prestados, em espécie, a todo o indivíduo que participe espontaneamente de um programa e possa oferecer o serviço ambiental. O mercado, neste caso, exerce papel de incentivos econômicos para os atores envolvidos. No entanto esse pagamento, em regra, definido pelo custo de oportunidade, geralmente implica valores de pouca expressão monetária, o que pode gerar expectativas excessivas com prejuízo à aderência de ofertantes prestadores de serviços. O custo de oportunidade é utilizado como sendo o custo de ter renunciado a uma oportunidade, benefício que poderia ser obtido a partir desta oportunidade renunciada o que poderia ser ganho no melhor uso alternativo.

Assim, considerando que os PSA geram recompensas aos prestadores de serviços na forma de remuneração pelos serviços ambientais, esses precisam obter recursos para seu desenvolvimento, que normalmente é financiado por taxas e subsídios ambientais. Ou seja, esses recursos financiarão a prestação pelos serviços ambientais prestados pelos produtores, os quais só estarão aptos a receber mediante o cumprimento de certificação da efetiva prestação do serviço ambiental.

Por outro lado, sem a existência do incentivo econômico e financeiro, podem ocorrer dificuldades de implantações dos projetos de desenvolvimento e conservação integrados com política de comando e controle. A Figura 1 que representa graficamente essa visão.

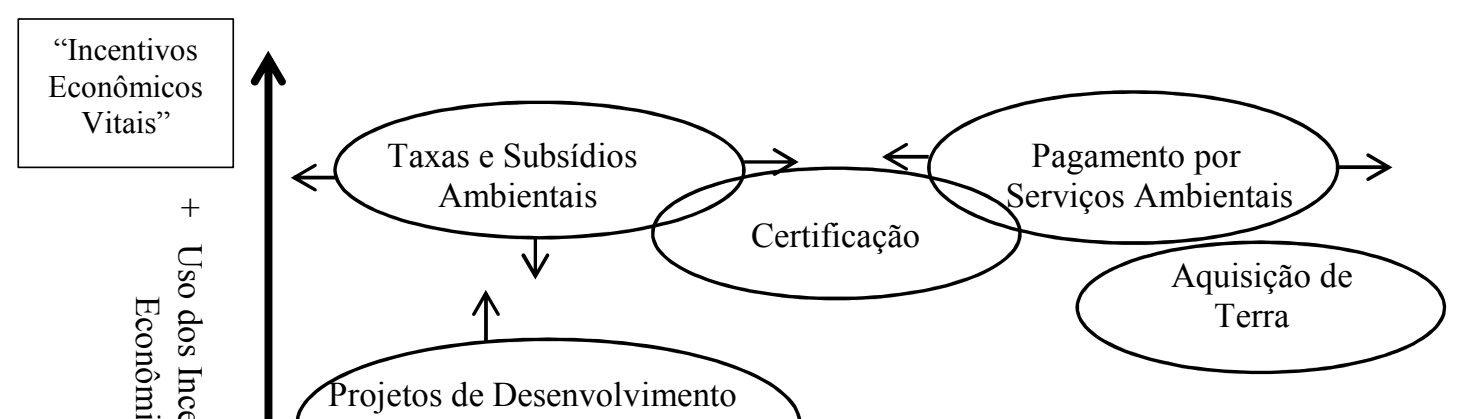

e Conservação Integradas 


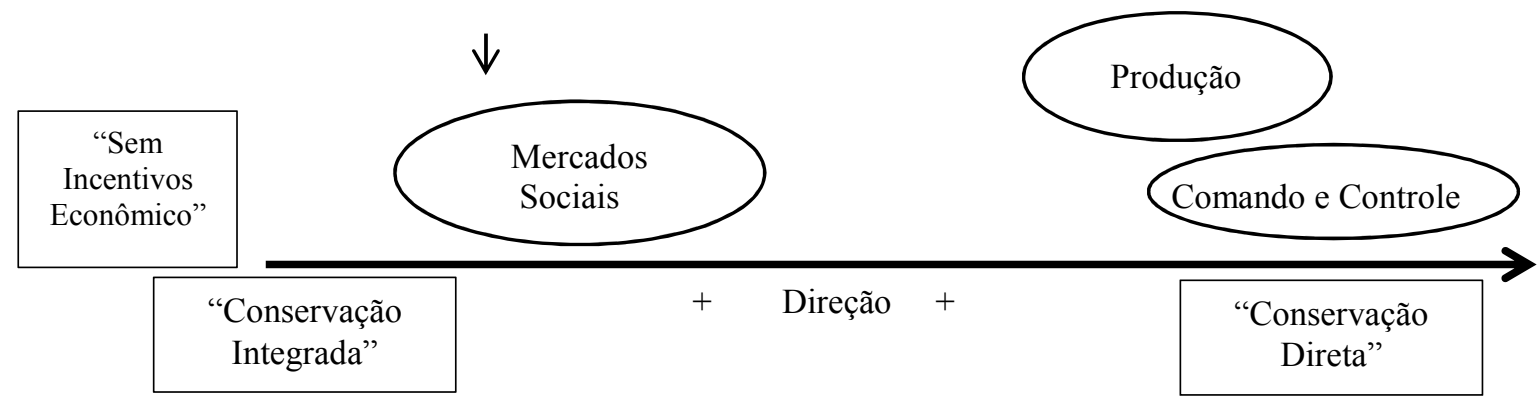

Figura 1 - Representação dos termos de PSA FONTE: Wunder (2005).

Pagiola e Platais (2007) definem PSA como um mecanismo para prover serviços ambientais indiretos, no qual aqueles que fornecem os serviços ambientais são pagos por provedoresrecebedores e aqueles que se beneficiam dos serviços ambientais são considerados usuário pagador, além disso os pagamentos são condicionais e a participação nos projetos deve ser voluntária. Na Figura 2, os autores explicam graficamente o mecanismo.

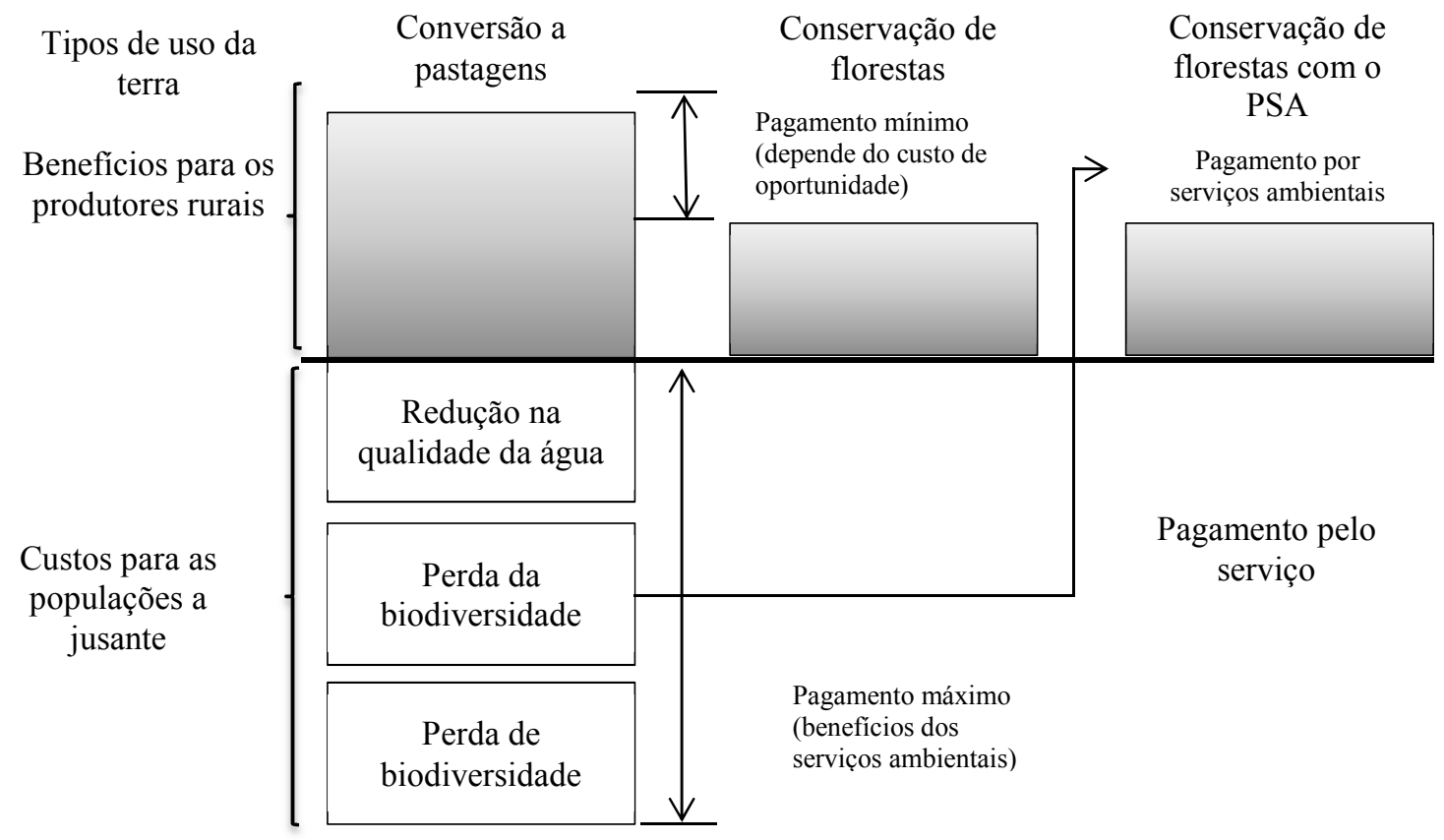

Figura 2 - Lógica dos programas de PSA

FONTE: Pagiola e Platais (2007) 
Reforçando a conceituação, Zolin (2010) defende que o PSA corresponde à remuneração dos serviços ecossistêmicos, caracterizando-se como um incentivo, remuneração justa derivada do esforço realizado por meio de indicadores que reflitam os reais benefícios sociais, ambientais e econômicos que ambos os provedores e usuários obtêm dos ecossistemas.

Por sua vez, Born e Talocchi (2002) sugerem que o termo PSA seja alterado para a denominação Compensação por Serviços Ambientais. Essas compensações podem ser de vários tipos: as transferências diretas de recursos financeiros; o apoio na obtenção de créditos; as isenções fiscais e tarifárias; as preferências para a obtenção de serviços públicos; o acesso às tecnologias e treinamento técnico; os subsídios.

Apesar de haver discordância de outros autores a respeito do termo PSA, o presente estudo adotará o termo PSA, por entender que a justificativa de Wunder (2005) convence: apesar do uso do termo pagamento, este representa também a ideia de compensação de outras formas que não o efetivo pagamento em moeda corrente, podendo emergir um mercado em que as trocas ocorrem sem haver a negociação em espécie.

Nesse sentido, Landell-Mills e Porras (2002) destacam que os esquemas de PSA documentados até hoje, na maioria das vezes, se encaixam em uma, ou várias das seguintes categorias $^{35}$ :

a) Captura e retenção de carbono - exemplos: captura de carbono por vegetação em crescimento, ou a condição de retenção de carbono no solo e na vegetação. Benefício pelo qual se paga: efeito potencial de mitigação das mudanças climáticas causadas por emissões antropogênicas;

b) Biodiversidade - exemplos: regulação e estrutura do ecossistema, diversidade genética e de espécies. Benefícios pelos quais se paga: valor de opção (uso futuro) e existência (conhecimento da existência e importância);

c) Proteção hídrica - exemplos: purificação da água, regulação de fluxo e sedimentação. Benefícios pelos quais se paga: qualidade e quantidade de água.

\footnotetext{
${ }^{35} \mathrm{O}$ sentido do termo categorias aqui utilizado é de classificação dos tipos de serviços ambientais.
} 
d) Beleza cênica - exemplos: paisagens naturais (e, em alguns casos, culturais). Benefício pelo qual se paga: recreação e opções para turismo (LANDELLMILLS; PORRAS, 2002).

Sabe-se, que, apesar da ideia defendida por Zolin (2010), na prática muitas vezes não é possível identificar o beneficiário, especialmente quando se trata do meio ambiente, pois a preservação da floresta beneficia a sociedade como um todo, quando se pensa que a floresta em pé elimina o gás carbônico e como consequência favorece a não elevação da temperatura, que é provocada pelo aquecimento global (poluição). Ou seja, é um bom exemplo de não exclusividade no consumo. Cada um pode consumir tanto quanto queira, sem prejudicar o outro consumidor, sendo um exemplo de bem público, portanto configura falha de mercado. Caberia algum mecanismo inspirado no artigo de Coase (1974) sobre os faróis de sinalização na Inglaterra? Ou seja, seria possível desenhar mecanismos de pagamento voluntário, mesmo que o bem de uso não seja exclusivo?

A gênese que fundamenta o PSA é que as pessoas que são beneficiadas com os serviços ambientais oferecidos façam contratos diretos para pagamento dos produtores locais ou usuários das terras (provedores de serviços), que adotam práticas de uso da terra e seus recursos de modos a prover sua conservação e restauração (WUNDER, 2007). A partir dessa linha argumentativa, é possível aferir que aqueles que fornecem serviços ambientais, pela conservação dos ecossistemas naturais, devem ser compensadas por beneficiários do serviço.

Especialistas encaram o PSA como uma forma eficiente de incentivar a preservação ambiental, uma vez que concilia atividades de preservação com geração de renda (questão de sobrevivência), principalmente para a população rural, onde geralmente a manutenção de áreas preservadas é encarada como prejuízo pelos produtores, que têm sua área produtiva diminuída pelas áreas de reserva legal e de preservação permanente. Esse fundamento também aborda questões de financiamento sustentável para áreas protegidas.

Nesse sentido três são as distinções entre PSA e outras formas de preservação. Primeira, os esquemas de PSA são baseados em áreas e não em produtos; segunda, a organização dos esquemas de PSA leva em consideração, quando do estabelecimento de acordos, se estes serão com recursos públicos ou privados; terceira, esquemas de PSA de uso restrito de ativos versus esquemas de construção de ativos (WUNDER, 2005). 
Cada uma dessas distinções é explicada pelo autor. A primeira o é especialmente nos meios utilizados para alcançar os efeitos de conservação ou reestruturação, ou seja, as áreas objeto de conservação são concedidas para essa finalidade com quantidade de terras preestabelecidas, a exemplo de servidões, definição de área protegida, entre outras; a segunda refere-se aos compradores do serviço ambiental, nos regimes públicos, o Estado atua em nome dos compradores, por meio da cobrança de impostos e subsídios para pagamento dos serviços ambientais, e nos sistemas privados, focados localmente, os compradores pagam diretamente aos provedores; e na terceira, o uso restrito do esquema de PSA recompensa o de conservação, limitando a extração de recursos e desenvolvimento de terras, ou deixando de lado determinadas áreas. Portanto, pode-se afirmar que são inúmeras as vantagens dos programas de PSA, se comparadas com as abordagens tradicionais de conservação ambiental.

Ademais, a proposta de PSA traz pelo menos duas inovações em relação à política de conservação e uso sustentável, considerando o caso específico da Floresta Amazônica. A primeira, os esquemas de PSA têm o potencial de se autofiscalizarem, pois, sendo a participação voluntária, os pagamentos podem ser reduzidos ou dispensados, caso seja detectado o não cumprimento do contrato por parte do provedor. A segunda, os PSA podem resultar no aumento de renda dos provedores de serviços ambientais, motivado pela perspectiva de o benefício exceder o custo de oportunidade (WUNDER, 2009).

Os proprietários são pagos por seus custos de conservação, e possivelmente pelos esforços de proteção ativa contra ameaças externas, o que reforça que os programas de PSA inovam na atividade de conservação, já que os provedores têm incentivo para isso (HARDNER; RICE, 2002).

Ferraro e Kiss (2002) e Ferrado e Simpson (2002 apud WUNDER, 2005) destacam que é inquestionável a vantagem absoluta dos PSAs em relação a outros instrumentos de conservação, mas sua eficiência dependerá do contexto, especificamente quando se analisarem os usos alternativos da terra.

Os esquemas de PSA devem lidar com três preocupações específicas: a primeira é a escolha dos destinatários do programa, identificada como a cadeia de valor agregado beneficiária do programa, ou seja, a distribuição vertical dos custos de oportunidade; a segunda é quanto à 
posse insegura da terra, já que em muitos casos os possuidores não têm sua terra legalizada; e a terceira é quanto ao uso ilegal dos recursos, por exemplo, a extração de produtos proibidos de florestas protegidas, entre outros, afirma Wunder (2005).

Para a implementação de um PSA quatro são as condições necessárias ${ }^{36}$ a saber:

\begin{abstract}
a) precondição econômica: que se refere à existência de uma externalidade (benefício externo ao provedor de serviços ambientais), que vale a pena ser compensada, ou seja, só estabelecem PSA caso haja disposição para pagamento de um valor maior do que o custo da provisão da externalidade;

b) precondição cultural: consiste em que os provedores de serviços ambientais respondam positivamente a incentivos econômicos, ou seja, se os atores se sentirem pouco motivados em receber pagamentos para mudar sua conduta em relação ao tipo de uso da terra, ou os considerarem socialmente inapropriados, os PSA não funcionarão;

c) precondição institucional: refere-se à perspectiva de que se estabeleça uma condição de confiança mínima entre usuários e provedores de serviços que seja capaz de gerar expectativa de cumprimento mútuo de contrato;

d) precondições informacionais: relacionadas à necessidade de definição (e mensuração) dos serviços ambientais pelos quais os provedores seriam compensados, bem como monitoramento de sua provisão e negociação de contratos, representados por custos de transação associados a essas tarefas, que, em alguns casos, podem representar pontos de estrangulamento para o PSA (WUNDER et al, 2009).
\end{abstract}

Associada à precondição econômica, a existência de uma externalidade é o fundamento econômico do PSA. Assim, um serviço ambiental prestado pela terra beneficia os usuários externos. Já a precondição institucional demanda infraestrutura institucional que seja capaz de administrar a transparência condicional do PSA de forma eficiente e transparente, justificando que um PSA necessita de instituições que sejam capazes de desempenhar o papel de segurança para os atores envolvidos.

Além disso, estudos já identificaram as condições necessárias para incorporar benefícios dos PSA, principalmente para a população de baixa renda, tais como garantia dos direitos de propriedade; instituições adequadas assegurando a participação dos atores locais; redução dos custos de transação para a participação dos atores; e, medidas colaterais de redução de pobreza (PAGIOLA et al, 2005; BRACER et al, 2007; WUNDER, 2007).

Mais uma vez fica demonstrado que a garantia dos direitos de propriedade, o ambiente institucional e os arranjos institucionais exercem uma função inquestionável para a evolução

\footnotetext{
${ }^{36}$ Condições sistematizadas a partir das experiências em várias partes do mundo.
} 
dos PSAs bem como para o surgimento do mercado de serviços ambientais pautado no conceito econômico.

Por sua vez, Wunder et al (2009) fazem uma distinção entre PSA local e internacional. O primeiro são os pagamentos diretos aos provedores dos serviços; o segundo é quando um país ou entidade administrativa receberia pagamentos para implementar políticas voltadas à provisão de serviços ambientais sob seu domínio. Há o destaque de que os PSA internacionais estão sendo discutidos como medidas contra o desmatamento ou Redução de Emissões por Desmatamento e Degradação (REDD). Em se tratando de recursos internacionais que viabilizam REDD, estes poderiam ser destinados também para financiar pagamentos diretos em âmbito local, entretanto, uma grande parte é aplicada pelos governos para reforçar mecanismos de comando e controle, de forma a assegurar a conservação ambiental em áreas com baixa governança.

Esquemas de PSA precisam encontrar um equilíbrio entre eficiência em curto prazo e justiça, esta última influenciando a viabilidade de longo prazo, afirma (WUNDER, 2005). Essa afirmativa precisa ser interpretada como a viabilidade dos projetos e que os compradores e vendedores encontrem na negociação dos serviços ambientais, objetos dos projetos, a maior satisfação possível nos contratos negociados.

Os defensores do PSA alertam que a inovação no financiamento dos PSA é uma necessidade urgente, pois as abordagens atuais oferecem pouco valor de recursos para pagamentos e que é preciso buscar novos financiamentos (especialmente do setor privado), proporcionado assim a melhoria dos meios de subsistência para as comunidades pobres, que geralmente vendem esses serviços. Os céticos dizem que isso vai trazer de volta as cercas, dissociando a conservação do desenvolvimento; que a distribuição de poder assimétrico significa consórcios de conservação poderosos que podem privar as comunidades de seus legítimos proprietários de terra no desenvolvimento de suas aspirações; e que a conservação comercial pode corroer culturalmente a atividade de conservação como atividade com fins não lucrativos (WUNDER, 2005).

Wunder et al (2009) contribuíram de maneira significativa para o estudo dos programas de PSA ao resumirem as fontes de financiamento e captação de recursos para o pagamento do serviço ambiental negociado (Quadro 4). 
Quadro 4 - Fontes e mecanismos de captação de recursos para PSA

\begin{tabular}{|c|c|c|c|c|}
\hline Função & Categoria & Exemplos/Tipos & Limitações para PSA & $\begin{array}{c}\text { Potencialidades para } \\
\text { PSA }\end{array}$ \\
\hline \multirow{5}{*}{$\begin{array}{l}\text { Fontes e } \\
\text { captação de } \\
\text { recursos }\end{array}$} & \multirow{3}{*}{ Tributos } & Impostos & $\begin{array}{l}\text { Lento processo de aprovação: } \\
\text { alocação de recursos atrelada } \\
\text { à opinião pública e a } \\
\text { processos políticos }\end{array}$ & $\begin{array}{l}\text { Institucionalização da } \\
\text { fonte de recursos, } \\
\text { Fluxo de recursos } \\
\text { relativamente estável }\end{array}$ \\
\hline & & Cobrança & $\begin{array}{l}\text { Vinculação ao uso direto de } \\
\text { produtos e serviços ambientais }\end{array}$ & $\begin{array}{l}\text { Fonte complementar de } \\
\text { recursos }\end{array}$ \\
\hline & & Taxas & $\begin{array}{l}\text { Destinação especifica (por } \\
\text { exemplo manutenção } \\
\text { serviços prestados) }\end{array}$ & $\begin{array}{l}\text { Fonte complementar de } \\
\text { recursos }\end{array}$ \\
\hline & $\begin{array}{l}\text { Acordos bi e } \\
\text { multilaterais }\end{array}$ & $\begin{array}{c}\text { Cooperação } \\
\text { internacional; } \\
\text { parcelas } \\
\text { nacionais e } \\
\text { internacionais; } \\
\text { doações; trocas } \\
\text { de títulos de } \\
\text { dívidas }\end{array}$ & $\begin{array}{l}\text { Altos custos de transação; } \\
\text { Mecanismo complexo para } \\
\text { pequenos e médios } \\
\text { produtores; } \\
\text { Alta variabilidade de preços } \\
\text { (p. ex., mercados de carbono) }\end{array}$ & $\begin{array}{lr}\text { Principal fonte } & \text { de } \\
\text { experiências pioneiras } \\
\text { quando as condições } \\
\text { ainda não são } \\
\text { favoráveis } & \text { para } \\
\text { incentivo privado; } & \\
\text { Menores custos de } & \text { dransação; } \\
\text { Flexibilidade na } & \\
\text { alocação de recursos. }\end{array}$ \\
\hline & Mercados & Cotas e Comércio & $\begin{array}{l}\text { Altos custos de transação; } \\
\text { Mecanismo complexo para } \\
\text { pequenos e médios } \\
\text { produtores; } \\
\text { Alta variabilidade de preços } \\
\text { (ex. mercados de carbono) }\end{array}$ & $\begin{array}{l}\text { Institucionalização da } \\
\text { fonte de recursos; } \\
\text { Alocação eficiente dos } \\
\text { recursos }\end{array}$ \\
\hline \multirow{6}{*}{$\begin{array}{l}\text { Gestão de } \\
\text { recursos }\end{array}$} & $\begin{array}{l}\text { Administração } \\
\text { pública } \\
\text { (nacional local) }\end{array}$ & $\begin{array}{c}\text { Ministério/ } \\
\text { Secretaria do } \\
\text { Meio Ambiente } \\
\text { (Estado e } \\
\text { Município) }\end{array}$ & $\begin{array}{l}\text { Sustentabilidade a tendências } \\
\text { políticas; } \\
\text { Altos custos de administração; } \\
\text { Poucas vezes eficiente }\end{array}$ & $\begin{array}{l}\text { Potencialmente } \\
\text { importante em etapas } \\
\text { iniciais de } \\
\text { implementação de PSA }\end{array}$ \\
\hline & \multirow{3}{*}{$\begin{array}{l}\text { Fundos } \\
\text { independentes } \\
\text { (nacionais ou } \\
\text { internacionais) }\end{array}$} & Fundos de Caixa & Recurso não sustentável & $\begin{array}{l}\text { Maior disponibilidade } \\
\text { de desembolso }\end{array}$ \\
\hline & & $\begin{array}{l}\text { Fundos } \\
\text { fiduciários }\end{array}$ & $\begin{array}{l}\text { Menor disponibilidade de } \\
\text { desembolso }\end{array}$ & $\begin{array}{l}\text { Maior sustentabilidade } \\
\text { do recurso }\end{array}$ \\
\hline & & Fundos rotativos & $\begin{array}{l}\text { Montante de recurso } \\
\text { desembolsado determinado } \\
\text { pelo risco do projeto }\end{array}$ & $\begin{array}{l}\text { Maior possibilidade de } \\
\text { captação de } \\
\text { empréstimos iniciais }\end{array}$ \\
\hline & $\begin{array}{l}\text { Órgãos e } \\
\text { agências } \\
\text { internacionais }\end{array}$ & Vários & Alto custo administrativo & $\begin{array}{l}\text { Maior propensão para } \\
\text { atração de recursos } \\
\text { internacionais }\end{array}$ \\
\hline & $\begin{array}{l}\text { ONG } \\
\text { (nacionais e } \\
\text { internacionais) }\end{array}$ & Vários & $\begin{array}{l}\text { Nem sempre aceitos como } \\
\text { gestores de recursos }\end{array}$ & $\begin{array}{l}\text { Maior propensão para } \\
\text { atração de recursos } \\
\text { internacionais }\end{array}$ \\
\hline
\end{tabular}

FONTE: Wunder et al (2009). 
No que se refere à valoração do serviço ambiental negociado, contrariamente à crença comum, muitas vezes não é necessário antes do estabelecimento PSA fazer uma avaliação econômica completa dos serviços ambientais no lado do comprador, e um estudo econômico dos retornos para o lado do provedor. Em princípio, a qualquer preço as duas partes podem negociar conjuntamente definindo "o preço certo"37. No entanto, alguns cálculos antes podem certamente ajudar cada um dos lados para reforçar suas posições de negociação, ou mesmo predeterminar se um esquema de créditos PSA é uma opção realista ou não, afirma (WUNDER, 2005). Isso contribui como um mecanismo de negociação entre comprador e vendedor para a negociação dos serviços.

Há de se ressaltar que a ideia de pagar pela preservação dos bens naturais não é nova. $\mathrm{Na}$ década de 1990, a Costa Rica abraçou a causa ao valorar bens ambientais e criar um fundo que taxa o uso da água e de combustíveis para remunerar os proprietários que realizassem atividades de preservação ambiental relacionadas ao programa, destaca Zúñiga (2005). O financiamento dos programas de preservação dos bens naturais na Costa Rica é por meio do impuesto ecológico $^{38}$. Tal solução baseia-se em mecanismo mandatório, portanto não seria um ato voluntário.

Da mesma forma, Pagiola et al (2005) apontam a Costa Rica como o exemplo mais antigo de implementação de uma política de governo voltada para a compensação financeira a proprietários rurais que pela conservação de florestas estão contribuindo para o incremento da biodiversidade bem como para a melhoria da qualidade de água para o setor produtivo, que é um dos atores-chave nesse mecanismo de PSA.

$\mathrm{Na}$ fase embrionária dos $\mathrm{PSA}^{39}$, dois são os obstáculos enfrentados: o primeiro diz respeito à demanda limitada - poucos usuários do serviço ambiental dispostos a pagar, confiantes em alguns casos, porque a ligação entre o uso da terra e a prestação do serviço ambiental não é suficientemente entendida ou ambígua -; o segundo é o conhecimento insuficiente sobre a dinâmica da oferta do serviço ambiental. Tal aspecto pode ser visto como um problema de direito de propriedade pouco definido, levando a custos de transação elevados. Uma vez

\footnotetext{
${ }^{37}$ Para o sequestro de carbono, um preço de mercado referencial já existe.

${ }^{38}$ Lei Florestal $\mathrm{n}^{0} 7.575$ que reconhece os serviços ambientais prestados pelos ecossistemas: hidrológico, sequestro de carbono, biodiversidade e paisagismo, e no entanto é mínima a relação direta entre os recursos captados e a prestação de serviços, com exceção dos créditos de carbono gerados pelos reflorestamentos. (ZÚÑIGA, 2005).

${ }^{39}$ Comentários a partir das experiências nos trópicos.
} 
superados os obstáculos, o desafio está em responder aos seguintes questionamentos: quais são as condições institucionais necessárias para que os fornecedores negociem um acordo de PSA? Se um PSA se estabelece, como ocorrerá seu funcionamento na gestão, nas transferências de benefícios e na utilização dos recursos na subsistência da comunidade local? Pouco é conhecido, por isso experimentos e pesquisas tornam-se necessários (WUNDER, 2005).

Pagiola et al (2005, p. 66) descrevem como operam alguns mecanismos de mercado de pagamento por serviços ambientais na América Central e do Sul. As principais características dos estudos dos casos nesses países evidenciam a necessidade de existência de um produto: os serviços fornecidos pelas florestas; de compradores desse produto - os beneficiários destes mesmos serviços gerados; e de vendedores do produto - os usuários das terras responsáveis pela tomada de decisões no gerenciamento das florestas e, portanto, na oferta dos serviços ambientais.

A partir de trabalhos já realizados com determinados serviços ambientais, a água, por exemplo, foi possível elencar as características de um PSA, a saber:
a) gerar o seu próprio financiamento (despertando interesses de investidores);
b) ser eficiente, enfocando esforços onde os benefícios de conservação sejam mais altos do que os custos sociais (o que não implica que seja suficiente para justificar o interesse privado, mas pode justificar o interesse público);
c) ser potencialmente sustentável significa que o PSA não deve depender dos desejos dos doadores, ONGs, mas do interesse próprio dos usuários e provedores de serviços;
d) basear pagamentos aos provedores nos pagamentos pelos usuários;
e) entregar os serviços hídricos de fato; e
f) ajustar o mecanismo às condições locais específicas onde o projeto está localizado (PAGIOLA;
PLATAIS, 2007).

Com exceção da letra e, as demais características aplicam-se para os demais serviços ambientais, por envolverem os mesmos benefícios de viabilidade de PSA.

Para ilustrar um PSA atrativo, Pagiola e Platais (2007) apresentaram a formatação de sua aplicabilidade, enfocando a prática a partir da teoria, como demonstrado na Figura 3.

1. Entendendo a ciência ...

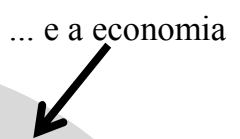

Associação usuários da agua 


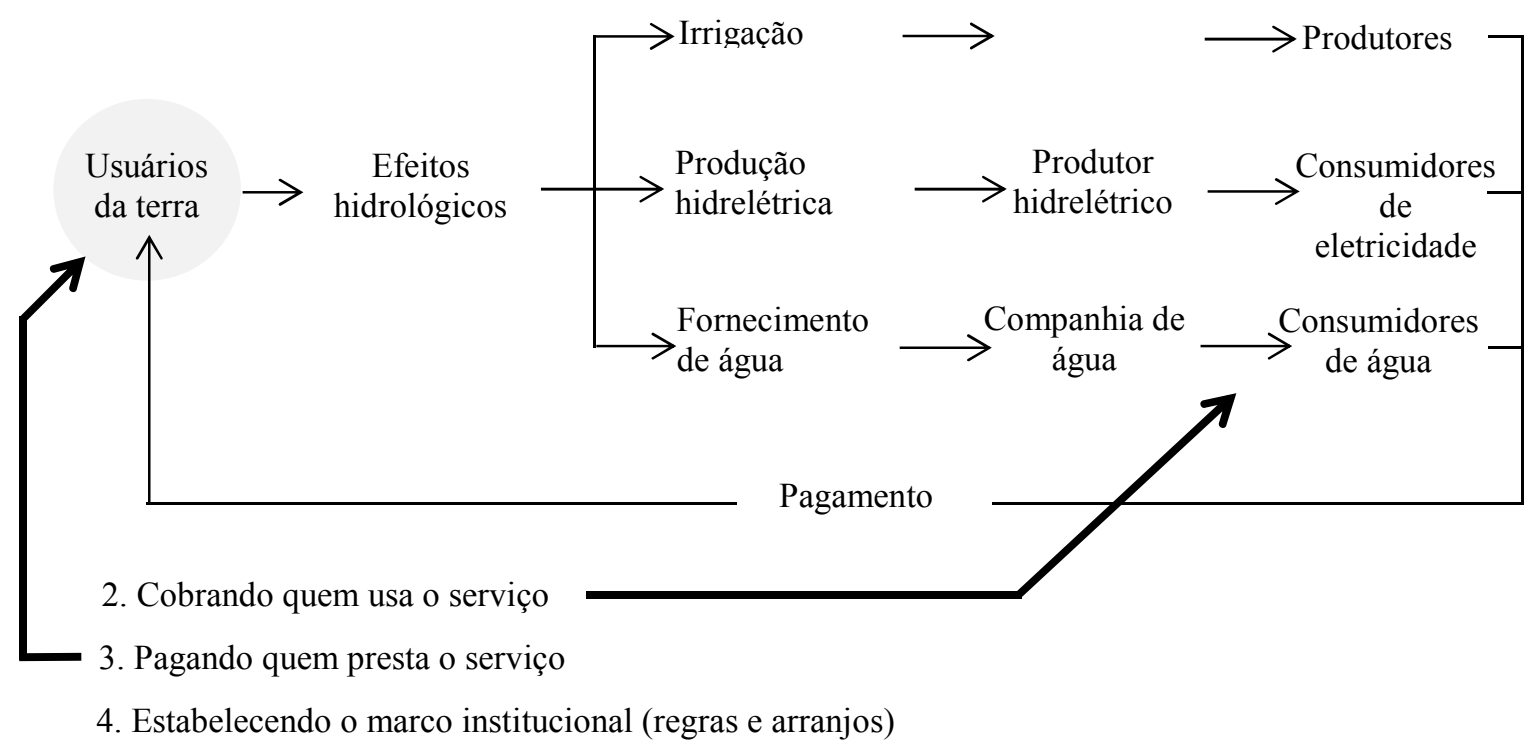

Figura 3 - PSA Da Teoria a Prática

FONTE: Pagiola e Platais (2007)

Na figura 3, é demonstrada a importância do estabelecimento de um marco institucional, com arranjos e regras bem definidas para que os programas de PSA possam funcionar adequadamente no fornecimento de serviços ambientais pelos provedores e no pagamento pelos compradores. Essa percepção coaduna com a visão de North (1990) de que as instituições e o ambiente institucional são importantes para diminuir a incerteza e estabelecer uma base estável para as relações contratuais.

Não obstante a atratividade dos programas de PSA muitas advertências prevalecem e merecem a realização de estudos para sua consolidação. Dentre elas destacam-se: fonte sustentável de financiamento para os compradores; confiança inicial para o programa, que deve ser construída com os estabelecimentos de regras de monitoramento e recompensas, o que muitas vezes leva tempo e exige um mediador honesto.

Uma política de serviços ambientais não pressupõe obrigatoriamente uma política de PSA, e os exemplos brasileiros demonstram essa distinção. O primeiro deles é o ICMS Ecológico; o outro, o Sistema Nacional de Unidades de Conservação (SNUC) ${ }^{40}$, mecanismos que muitas vezes se articulam, ambos considerados uma política de serviços ambientais.

\footnotetext{
${ }^{40}$ Sistema Nacional de Unidade de Conservação é uma política de serviço ambiental que não representa especificamente um PSA. É considerado um avanço da legislação brasileira em relação à preservação do serviço ambiental.
} 
Apesar de o Brasil ainda não ter uma legislação específica ${ }^{41}$ acerca do PSA, várias são as iniciativas ${ }^{42}$ de casos desses serviços, oriundas de diferentes ativos ambientais.

No âmbito nacional, a instituição da Política Nacional dos Serviços Ambientais prevê que serão remuneradas iniciativas de proteção ou renovação dos solos; manutenção da biodiversidade; controle das emissões de gases causadores do efeito estufa; manutenção do ciclo da água, entre outras. Os recursos dos programas serão arrecadados por um fundo e o valor a ser pago pela preservação será definido por uma comissão multidisciplinar.

Os programas de PSA atualmente existentes geralmente estabelecem acordos formais entre compradores e provedores para instituir regras sobre assuntos como:
a) a definição do serviço ambiental ou o uso da terra e tecnologia necessários para assegurar o serviço;
b) condicionalidade da provisão monitorada e sanções, em caso de diferentes graus de descumprimento (e da atribuição e de responsabilidade);
c) a duração da transação que envolve assuntos de permanência na provisão dos serviços ambientais e nos usos da terra; $\mathrm{e}$
d) as modalidades de pagamento (forma, frequência, momento de entrega, receptores entre outros). No que diz respeito à frequência, o contrato deve ficar muito claro quanto a se o pagamento será ex ante ou ex post (WUNDER et al, 2009).

Reforçando as condições de implementação de um PSA, é fundamental haver alta condicionalidade do esquema, a qual será assegurada por uma combinação de monitoramento capaz de detectar seu cumprimento ou não, bem como sanções de redução ou dispensa de pagamentos àqueles provedores que não cumprirem com o estipulado em seus contratos.

Para ilustrar a estrutura de um contrato de PSA, constam nos Anexos 1 e 2 modelos de contratos utilizados apresentados por Wunder et al (2009) nos programas da Amazônia Legal. Ressalte-se que a aplicabilidade desses modelos no Brasil deve adequar-se à legislação brasileira de contratos regidas pelo Código Civil, Lei no ${ }^{\circ} 10.406$ (BRASIL, 2002).

\footnotetext{
${ }^{41}$ Várias são as discussões legislativas acerca do PSA. De acordo com busca nos sítios eletrônicos da Câmara dos Deputados, Senado Federal, Secretarias Estaduais de Meio Ambiente e das Assembleias Legislativas Estaduais, foram identificadas iniciativas tanto no âmbito federal (duas leis, dois decretos e nove PLs) quanto no âmbito estadual (14 leis e seis decretos). Destaca-se o projeto de Lei $\mathrm{n}^{\circ}$ 792, de 2007, e seus apensos, que atualmente se encontram em tramitação, que já foi aprovado pela Comissão de Agricultura, Pecuária, Abastecimento e Desenvolvimento Rural, da Câmara dos Deputados em 2010. A proposta foi examinada de forma conclusiva pelas comissões de Meio Ambiente e Desenvolvimento Sustentável, e de Constituição e Justiça e de Cidadania. A proposta define como prioridade o pagamento pelos serviços ambientais prestados em ecossistemas sob maior risco socioambiental, e determina que só pode participar do programa quem comprovar o uso ou ocupação regular do imóvel.

${ }^{42}$ A partir do ano 2000, com o Programa de Desenvolvimento Socioambiental da Produção Familiar Rural (Proambiente), iniciou-se uma intensa discussão acerca do potencial de PSA na região Amazônica.
} 
Por fim, só justifica pagar por um serviço que a natureza oferece, quando se estimula a conservação e a preservação dos serviços ecossistêmicos (benefícios que as pessoas retiram dos ecossistemas). Isso tem custos para os usuários de terras, o reflorestamento gera despesas, levando em conta o custo de oportunidade. Ou seja, os programas de PSA geram ou custos públicos para a gestão dos programas ou custos privados para os participantes do programa. $\mathrm{O}$ problema pode ser visto como sendo o de implantar benefícios que motivem a cooperação dos produtores e demandantes dos serviços ambientais.

\subsubsection{Das concepções de mercado de serviços ambientais}

O Programa das Nações Unidas para o Meio Ambiente (PNUMA) ${ }^{43}$ aponta que os instrumentos de PSA podem promover mudanças importantes nas dinâmicas do mercado, ressaltando que esses são mais eficientes que as políticas de comando e controle para fazer com que os custos de poluição recaiam efetivamente sobre os causadores da poluição. Os instrumentos de PSA reduzem os custos de cumprimento da legislação se as atividades de redução de contaminação se direcionarem para as áreas onde os resultados são mais fáceis de serem atingidos. Eles ainda geram incentivos para reduzir a poluição abaixo dos níveis definidos por lei e requerem menos gestão do setor público que as políticas de comando e controle, entre outros.

O mesmo programa destaca que os instrumentos econômicos são estruturados para alcançar três objetivos principais: corrigir problemas relacionados aos direitos de propriedade que contribuem para a contaminação ou para a má gestão dos recursos; estabelecer e reforçar os preços dos recursos consumidos e dos impactos ambientais associados à produção; e subsidiar a transição para comportamentos mais desejáveis com relação aos impactos sobre os recursos.

MacDonald, Condor e Morrison (2004), da mesma forma, afirmam que os instrumentos econômicos raramente são substituídos pelos marcos regulatórios e por outras abordagens, eles apenas possibilitam que se alcancem resultados ambientais desejáveis a menores custos.

Jacobs (1997) e Van Hauwermeiren (1999) citam três tipos de incentivos econômicos: os impostos, os direitos transacionáveis e os depósitos retornáveis. MacDonald et al (2004)

\footnotetext{
43 PROGRAMA DAS NAÇOES UNIDAS PARA O MEIO AMBIENTE (PNUMA). Disponível em:
} $<$ http://www.pnuma.org.br/publicacoes.php>. Acesso em: 11 ago 2012. 
utilizando-se dos mesmos incentivos econômicos, dividem-nos entre instrumentos baseados nos preços, considerados os impostos, taxas, subsídios e as ofertas públicas de incentivos que visam influenciar o desempenho ambiental por meio da internalização das externalidades; e os baseados nas quantidades, que definem padrões e/ou limites de contaminação, são os casos dos diretos transacionáveis e das indenizações ambientais, que consistem em um pagamento do causador da externalidade para aqueles que sofrem com ela. E, ainda, os depósitos retornáveis funcionam de forma a incentivar determinados comportamentos que cumpram boas práticas ambientais.

A utilização do instrumento PSA decorre, de um lado, do reconhecimento de que os ecossistemas efetivamente prestam serviços importantes que devem ser conservados; e, por outro lado, do entendimento de que, enquanto tais serviços não fizerem parte do mercado, não farão parte da tomada de decisões dos agentes que se relacionam com eles e, consequentemente, correrão o risco de se extinguirem em benefício de outras atividades rentáveis (LANDELL MILLS; PORRAS, 2002; PAGIOLA et al, 2005; WUNDER, 2005).

Duas são as justificativas para essa afirmação: a primeira é que muitas vezes os serviços ambientais geram benefício social difuso, enquanto os custos por sua manutenção recaem sobre alguns poucos indivíduos privados, ficando evidente que os custos privados são diferentes, assim como o são os benefícios; a segunda é que comumente os serviços ambientais não se caracterizam por direitos de propriedade claramente definidos, isto é, são gerados livremente pela natureza sem a existência de um proprietário, um dono, e, portanto, não são transacionados no mercado e são utilizados até a exaustão, o que é chamado por Hardin (1968) como "tragédia dos comuns".

Considerando que os serviços ambientais efetivamente possuem valor e são exauridos por sofrerem a tragédia dos comuns e por não fazerem parte do mercado, surge a ideia de pagamento por esses serviços, que consiste precisamente no reconhecimento do valor e em alguma forma de recompensa para os que ajudam a conservar esses serviços, sendo, portanto, uma forma de internalizar as externalidades, de modo que a proteção e a conservação dos serviços ambientais passem a fazer parte das decisões econômicas de agentes individuais (WUNDER, 2005).

A criação de mercado é um mecanismo potencialmente eficiente para captação de recursos; 
porém, para funcionar como mecanismo de financiamento, direcionado à conservação e à provisão de serviços ambientais, ele depende de políticas de incentivo à demanda, tal como aconteceu no caso do mercado de carbono, que surgiu em função de metas de redução de emissões adotadas por vários países industrializados, no âmbito da política internacional do clima, considerando-se que os compradores desse mercado deverão cumprir as metas estabelecidas (WUNDER et al, 2009).

Na discussão do tema mercado de serviços ambientais, ganha importância o estabelecimento dos critérios para compra e venda desse serviço, os quais precisam ser muito claros e devidamente acordados por todos os atores envolvidos, ou seja, o vendedor deve saber exatamente o que vende e como seu valor é calculado, devendo ainda, todos estarem preparados para o monitoramento da prestação efetiva do serviço ambiental. O estabelecimento desses critérios, na maioria dos PSAs, a exemplo da proteção de bacias hidrográficas, gera custos de transação, com a existência de heterogêneos atores e complexos processos de negociação, e direitos de propriedade por vezes não bem definidos, além de carecerem de marco regulatório eficiente, e a operação via mercado poderá deixar de ser atraente. A lógica de mercado tem como característica a alocação dos recursos na sociedade via regras de oferta e demanda.

Quanto ao valor da remuneração a ser paga pela prestação de serviços ambientais decorrente de uma negociação de mercado, importa saber o quanto o comprador está disposto a pagar e o quanto o vendedor está disposto a receber, porém, as experiências têm demonstrado que a oferta e a demanda não são suficientes para garantir o sucesso de um PSA. Ademais, é preciso que as instituições responsáveis pelas operações de compra e venda do serviço ambiental sejam confiáveis e que o vendedor do serviço, em geral o produtor rural, compreenda que, se ele deixar de produzir em determinada área e a floresta ali se desenvolver, ele receberá pela conservação, tornando-se tão importante quanto se fosse uma área cultivada, e que haverá mudanças e/ou restrições no uso da terra em sua propriedade.

Landell-Mills e Porras (2002), em estudo realizado nas Américas, Caribe, Europa, Ásia, África e Oceania, identificaram 61 casos de PSA relacionados à água e, como resultado, identificaram questões relacionadas à evolução dos mercados de serviços ambientais, incluindo seus potenciais e suas fragilidades. No estudo foram identificadas características comuns nos PSAs da água, entre elas: grande parte dos programas apresentam escala local, com número reduzido de pessoas envolvidas; uso predominantemente rural ou próximo de 
pequenas cidades; relação direta entre beneficiário e provedor dos serviços; e valoração do serviço com pouca relação com a valoração monetária dos recursos naturais e dos serviços ambientais, quantificada pelo custo de oportunidade da terra, na maioria dos casos.

Esse estudo revelou, ainda, que a maior parte dos programas de PSA tem participação do tanto do setor público quanto privado, e que os compradores ${ }^{44}$ (beneficiários) dos serviços são, em geral, governo e empresas públicas, e pessoas físicas, enquanto os proprietários de terras são os principais vendedores (ofertantes) desses serviços. O setor privado, apesar de ter papel determinante na oferta e na demanda dos serviços ambientais, a sua função é de intermediação entre compradores e vendedores, entre outras inerentes a seu funcionamento, tem sido assumida por governos, comunidades e, especialmente, por ONGs locais.

Uma característica revelada no estudo e que contribui para as condições de surgimento de mercado é quanto à competitividade. $\mathrm{O}$ mercado de serviços ambientais revelou-se ser mais cooperativo do que competitivo; por um lado, as áreas de mananciais possuem, na maioria das vezes, mais de um proprietário, ficando evidente que a oferta não é de apenas um proprietário individual; por outro lado, os beneficiários em geral atuam em grupo, já que têm os mesmos interesses que vão, via de regra, contra os interesses de ofertantes. O conflito de interesses entre compradores e vendedores gera negociação entre atores com diferentes pontos de vista e necessidades, assim, para assegurar a proteção, os beneficiários têm de garantir, pelo menos, o custo de oportunidade relacionados aos rendimentos que os proprietários deixarão de auferir pelo uso alternativo da terra (LANDELL-MILLS; PORRAS, 2002).

A competitividade no mercado de serviços ambientais deve ser defendida, pois os recursos existentes para financiamento de projetos são insuficientes, e o estímulo à competição entre os ofertantes pode gerar melhores relações entre custo e efetividade, o que pode contribuir para maximizar os benefícios ambientais. Comungam dessa ideia Landell-Mills e Porras (2002).

Os Estados Unidos são um país que avançou na criação de mercados competitivos para serviços ambientais instituindo a comercialização de poluentes (efluentes) de mananciais. $\mathrm{O}$ funcionamento desse mecanismo tem como ponto de partida a determinação pelo governo

\footnotetext{
${ }^{44}$ Os maiores compradores individuais de serviços ambientais relacionados à água são o governo e as empresas públicas; da mesma forma, os governos possuem extensas áreas de terras, influenciando diretamente na oferta de serviços ambientais (LANDELL-MILLS; PORRAS, 2002).
} 
americano de metas de qualidade de água em determinados mananciais, definindo responsabilidade para os maiores emissores de efluentes para o cumprimento dessas metas. A indústria que porventura não puder cumprir com suas metas, poderá comprar créditos de contaminação, criando dessa forma a demanda por esses créditos. Os créditos podem ser gerados de diversas formas, desde reduções de emissões até atividades agrárias, tais como plantação de árvores. Dessa forma, percebeu-se a criação de mercado competitivo de oferta de créditos de contaminação. Essa lógica americana coaduna-se com a lógica existente no mercado de carbono, a partir do protocolo de Quioto.

Como contribuição para o presente estudo, Landell-Mills e Porras (2002) defendem a criação de commodities pelas quais o serviço ambiental seja remunerado, ou seja, a transformação do serviço em um bem transacionável no mercado.

Para entender essa proposição, é fundamental a compreensão da palavra commodities, plural de commodity, termo inglês cuja tradução representa basicamente mercadoria .

Azevedo (2001) defende que, para receber a qualificação de commodity, é necessário que uma mercadoria atenda a pelo menos três requisitos: padronização em um contexto internacional; possibilidade de entrega nas datas acordadas entre comprador e vendedor; e possibilidade de armazenagem ou de venda em unidades padronizadas.

Complementando o entendimento sobre o conceito de commodity, Toledo Filho (1997) ressalta que as mercadorias deverão ter características específicas:

a) padronização: deve ser uma mercadoria com nível mínimo de variação;

b) pouca perecibilidade: normalmente deve ser armazenada ou transportada para entrega futura;

c) ampla escala de consumo: o produto exige grandes disponibilidades para negociação e transação;

d) o mercado de commodity deve ter um fluxo de negociação pelo preço de equilíbrio, isto é, pela oferta e demanda existentes;

e) condição de matéria-prima ou de semielaboração: a commodity não pode sofrer um complexo sistema de produção, pois sua disponibilidade estaria afetada em caso de falha na cadeia produtiva; 
f) os preços da commodity a futuro e à vista são estritamente correlacionados, visto que o preço futuro deve convergir para o preço à vista no vencimento.

As commodities são produtos básicos, bens comerciáveis, homogêneos e de amplo consumo, que podem ser produzidos e negociados por uma ampla gama de empresas, na maioria das vezes. Os principais tipos de commodities são:

a) agrícolas (café, trigo, soja, milho, açúcar);

b) minerais (ouro, petróleo, ferro, alumínio);

c) financeiras (dólar, euro, real, índices futuros);

d) ambientais (créditos de carbono, condições climáticas médias em regiões do planeta);

e) recursos energéticos (energia elétrica);

f) químicas (ácido sulfúrico, sulfato de sódio, fertilizantes).

A importância das commodities para a economia reside no fato de que, embora sejam mercadorias primárias ou minimamente industrializadas, possuem "negociabilidade" global, que ocorre geralmente em bolsas de mercadorias. Portanto seus preços são definidos em nível global, pelo mercado internacional, de acordo com fatores de oferta e demanda, sendo suscetíveis de oscilações nas cotações de mercado, em virtude de perdas e ganhos nos fluxos financeiros. Assim, em geral, as commodities são produzidas em grandes quantidades por vários produtores/empresas. Como não apresentam diferenciação, têm baixo valor agregado, marca de referência ou serviço que as diferenciem ${ }^{45}$.

Para o mercado do serviço ambiental, a proposta apresentada pelas autoras Landell-Mills e Porras (2002) de commodities resultantes da transformação dos serviços ambientais em produtos comercializáveis, é um importante avanço, que merece ser investigado para sua aplicação, quando negociados outros serviços ambientais. No Quadro 5, estão dispostas a relação dos serviços e sua respectiva transformação em commodities.

Quadro 5 - Commodities para serviços ambientais

\begin{tabular}{|c|l|}
\hline Serviços & Commodities \\
\hline Qualidade da água & - Proteção de mananciais contratos de melhores práticas de manejo \\
\hline
\end{tabular}

\footnotetext{
${ }^{45}$ BOLSA DE MERCADORIAS E FUTURO. Disponível em:

$<$ http://www.bmfbovespa.com.br/home.aspx?idioma=pt-br $>$. Acesso em: 06 jan. 2013.
} 


\begin{tabular}{|c|l|}
\hline & - Créditos de qualidade de água (por exemplo redução de sedimentos \\
& e carga de nutrientes na água) \\
& - Aquisições de terras em áreas de mananciais \\
& - Áreas protegidas em propriedades privadas (por exemplo Reserva \\
& Particular do Patrimônio Natural - RPPN) \\
\hline \multirow{3}{*}{ Regulação do lençol freático } & - Créditos de salinidade tanto da água quanto do solo \\
& - Crédito de transpiração \\
& - Produtos que não provocam salinização \\
& - Licenças de redução de fluxos de água \\
\hline Proteção de habitat aquático & - Contratos de melhoras práticas de manejo \\
& - Produtos livres de animais sob proteção \\
& - Arrendamento de terras \\
\hline Controle de contaminação do solo & - Contratos de reestruturação de habitat de animais sob proteção \\
& - Direitos de propriedade para uso da água \\
\hline & - Aquisições de terras \\
\hline & - Plantações de espécies de plantas filtrantes \\
\hline & - Contratos de proteção de mananciais \\
\hline & - Aquisições de terras \\
\hline & - Direitos de propriedade para uso da água \\
& - Arrendamento de mananciais \\
\hline
\end{tabular}

FONTE: Adaptado Landell-Mills e Porras (2002).

Da mesma forma, apesar da evolução tímida do mercado de serviços ambientais nos casos estudados por Landell-Mills e Porras (2002), as autoras destacam que os altos custos de transação, tanto do lado da oferta quanto da demanda podem afetar a criação e a evolução do mercado de serviços ambientais relacionados à água. Essa conclusão coaduna-se com a teoria dos custos de transação e com a hipótese de pesquisa de que os custos de transação devem ser baixos o suficiente para que o mercado de serviços ambientais possa operar.

Além disso, a falta de informação científica, da participação dos atores sociais, de disposição a pagar, pode se dar pela resistência desses atores, que utilizam-se dos serviços ambientais de forma gratuita ou pela falta de recursos que contribuem com as restrições da demanda no mercado de serviços ambientais. Do lado da oferta, o baixo conhecimento do mercado e da capacidade para explorar as oportunidades, a falta de credibilidade na oferta dos serviços, e a resistência cultural dos proprietários em não ter autonomia para decidir o que fazer com suas terras são as restrições apontadas para criação e evolução do mercado de serviços ambientais (LANDELL-MILLS; PORRAS, 2002).

Os resultados apontados pelo estudo dos PSA de Landell-Mills e Porras (2002), de forma genérica, sugerem importantes passos para a implantação de um mercado de PSA organizado. Esse esquema apresenta a novidade da definição de commodities em relação aos demais já comentados. Os passos estão resumidos no Quadro 6. 
Quadro 6 - Passos para implantação de mercado de PSA

\begin{tabular}{|l|l|}
\hline \multicolumn{1}{|c|}{ Passos } & \multicolumn{1}{c|}{ Atividades/Benefícios } \\
\hline Primeiro verificar se o serviço existe e se é positivo & $\begin{array}{l}\text { Nesse momento, avaliam-se quais atividades florestais } \\
\text { proporcionam o serviço ambiental a ser remunerado }\end{array}$ \\
\hline Segundo geração de disposição a pagar & $\begin{array}{l}\text { Promover a percepção entre os beneficiários de que o } \\
\text { manejo adequado de florestas por terceiros tem um valor e } \\
\text { é positivo mantê-los }\end{array}$ \\
\hline $\begin{array}{l}\text { Terceiro Definir uma comodity que funcione como } \\
\text { proxy do serviço ambiental a ser remunerado }\end{array}$ & $\begin{array}{l}\text { A definição do instrumento irá transformar o serviço } \\
\text { ambiental em um bem transacionável no mercado }\end{array}$ \\
\hline $\begin{array}{l}\text { Quarto desenhar e implantar um mecanismo de } \\
\text { PSA }\end{array}$ & Definir as instituições de suporte para o PSA \\
\hline Quinto atividade piloto e feedback & $\begin{array}{l}\text { A implantação do projeto piloto e sua avaliação permitem } \\
\text { a efetiva estruturação do PSA e do mercado associado }\end{array}$ \\
\hline
\end{tabular}

FONTE: Landell-Mills e Porras (2002)

Por outro lado, contrários à tese defendia por Landell-Mills e Porras (2002), quanto à necessidade de mercado organizado para os serviços ambientais, Wunder et al (2009), em estudo publicado sobre a Amazônia Legal, afirmam que:

Ocorre um frequente mal-entendido de que PSAs requerem mercados para funcionar, afirmando que apenas os serviços relacionados ao carbono, considerado serviço ambiental homogêneo, se desenvolveram, enquanto os serviços da biodiversidade, água e beleza cênica são localmente específicos (WUNDER et. al, 2009).

Os mesmos autores ainda justificam que, em sua maioria, os PSA são considerados monopsônicos (transações com um único comprador) ou oligopsônicos (poucos compradores), afirmando que dificilmente sob condições de mercado com múltiplos provedores e compradores, muitas vezes espacialmente dispersos, a maioria dos PSA não iria surgir, em função dos altos custos de transação.

Apesar da ideia contraditória do surgimento de um mercado de PSA organizado, Wunder et al (2009) deixam claro que os mercados não seriam precondições necessárias ou suficientes para o surgimento e implantação de PSA, podendo os desenhos basear-se na teoria de contratos.

Portanto, inúmeros são os desafios para o funcionamento adequado de um mercado de serviços ambientais visto tratar-se de um problema complexo, e seu surgimento vai além do problema de precificação. É notório que os pagamentos nas modalidades existentes não demonstram sustentabilidade ao longo do tempo, especialmente quanto à origem dos recursos alocados, sendo necessário que a ação espontânea de agentes, ofertantes e demandantes, efetuando trocas de bens ou serviços, sejam estudadas para que se possa vislumbrar a 
existência de um mercado de serviços ambientais organizado.

\subsection{Mercado de serviços ambientais do carbono}

A Organização das Nações Unidas (ONU), preocupada com o bem-estar e com a preservação de boas condições de vida das gerações futuras, criou mais um mecanismo para tentar eliminar diferenças, para distribuir recursos e preservar o meio ecológico com a limitação da quantidade de emissão de gases de efeito estufa (GEEs), com os quais as empresas dos países desenvolvidos, ao realizarem o processo de industrialização, poderiam causar dano ambiental.

Nesse sentido, como alternativa de solução encontrada para o problema, surgiu o mercado de carbono, que objetiva negociar a redução das emissões de dióxido de carbono, teoricamente auxiliando na mitigação das mudanças climáticas. Para compor tal sistema, é preciso a elaboração de uma série de metodologias, regulamentações e estruturas de monitoramento de redução das emissões e comercialização dos créditos de carbono ${ }^{46}$. Assim, trata-se de um bem público utilizado pelos países desenvolvidos como meio de inibir a produção de poluentes no planeta.

A legislação atual estabeleceu níveis máximos de emissões de certos gases, segundo ela, aqueles que conseguissem manter o volume de emissões abaixo do estabelecido tinham direito a títulos de créditos equivalentes à porção reduzida, os quais podiam ser vendidos àqueles que não tiveram o mesmo sucesso, para que não infringissem as regras. Dessa maneira, os que realizaram investimentos para melhorar a qualidade de seus processos operacionais teriam uma recompensa e, por outro lado, aqueles que não o fizeram ou não o fizeram em montante suficiente, teriam de pagar pela poluição produzida Surgiu, então, o mercado do crédito do carbono.

O maior mercado de carbono é o estabelecido pela União Europeia para cumprir seus compromissos sob o Protocolo de Quioto, que coloca o sistema como um dos mecanismos de flexibilização adicionais às ações tomadas em nível nacional para o corte nas emissões. Esse protocolo permitiu que o mecanismo fosse aperfeiçoado ao longo do tempo alcançando níveis

\footnotetext{
${ }^{46}$ Título de direito sobre bem intangível e incorpóreo transacionável (Art. $3^{\circ}$, XXVII, Lei no ${ }^{\circ} 2.651$, de 2012).
} 
desejáveis para redução dos danos ambientais ${ }^{47}$.

Sob as regras do Protocolo de Quioto, o mercado de carbono é um mecanismo que busca diminuir custos para chegar a um corte absoluto das emissões. Assim, é determinado aos países que têm compromissos de redução ${ }^{48}$ um teto para suas emissões pela alocação ou leilão de "permissões".

A partir daí, os países ou empresas têm de montar estratégias para se manter abaixo da cota de emissões, o que possibilita o surgimento do comércio de permissões (quando um agente emite menos que a cota e vende para outro que está acima dela) ou de compensações, na hipótese emissão de alocação. Essa alternativa tem sido utilizada na Europa e nos Estados Unidos, mesmo antes da vigência do Protocolo de Quioto, em função de acordos internos similares. Grandes interessados em sua aquisição têm sido as organizações não governamentais (ONGs) da área ambiental, que compram tais títulos para evitar que empresas poluentes o façam, e, portanto, continuem a poluir.

Nas determinações do Protocolo de Quioto, as partes poderão cumprir seus compromissos de redução de emissões e remoção de GEEs por meio de três alternativas: a implementação conjunta; a comercialização de emissões; e a instituição de mecanismo de desenvolvimento limpo (MDL).

A implementação conjunta consiste no acordo entre dois membros do Anexo I do Protocolo de Quioto para estudo, desenvolvimento e implementação de novas tecnologias para contenção de suas emissões de GEEs, que possam beneficiá-los igualmente. O objetivo seria a concentração de esforços e recursos financeiros para a solução de problemas comuns. $\mathrm{O}$ comércio de emissões prevê a comercialização, entre as partes do Anexo I, dos adicionais de redução de emissões obtidos, ou seja, o volume de redução de emissão de GEEs além do previsto no Protocolo. Assim, as partes que tiverem sucesso em suas medidas de contenção de emissões, não necessitando, portanto, exercer inteiramente seu direito de poluir, poderão transacionar a quota de "direito" que deixaram de usar com os países que não conseguiram atingir suas metas. As partes somente poderão utilizar esses créditos como medida complementar para cumprir seus compromissos, assim terão de empreender procedimentos

\footnotetext{
${ }^{47}$ MINISTÉRIO DA CIÊNCIA E TECNOLOGIA E INOVAÇÃO. Disponível em: $<$ http://www.mct.gov.br/index.php/content/view/77650.html>. Acesso em: 30 abr. 2013

${ }^{48}$ Países do Anexo I do Protocolo de Quioto, ver p. 7 da presente pesquisa.
} 
domésticos para redução efetiva de suas emissões, como determina o Protocolo de Quioto.

E, ainda, o mecanismo de desenvolvimento limpo (MDL) tem como objetivo principal o de auxiliar os países em desenvolvimento na implantação de tecnologias de recuperação e preservação ambiental e de ajudar os países desenvolvidos a cumprir suas metas de redução de emissões. Assim, imputa-se aos maiores poluidores um encargo por comportamento agressivo ao meio ecológico, mas de custo inferior ao que teriam de incorrer para ajustar seu próprio processo operacional a condições adequadas sob o ponto de vista das emissões permitidas $^{49}$.

Por sua vez, para melhor compreender a participação brasileira nas negociações do regime de mudanças climáticas, é necessário salientar que, no referente às emissões de carbono, o Brasil tem grandes vantagens e uma grande desvantagem. As vantagens são: ser um país de renda média (estando fora dos compromissos obrigatórios de redução de emissões de carbono correspondentes aos países desenvolvidos), ter uma matriz energética com forte peso da hidreletricidade, muito limpa do ponto de vista das emissões estufa, e possuir em seu território grande parte das florestas mundiais. A grande desvantagem é ter uma grande emissão de carbono derivada do uso da queimada na agricultura tradicional e do desmatamento na região da Amazônia.

Dados revelam que as emissões de carbono do Brasil são ao redor de 2,5\% das mundiais: quase $25 \%$ são procedentes da indústria e da agricultura modernas e $75 \%$ da agricultura tradicional, da conversão de uso na fronteira agrícola e das atividades madeireiras ineficientes e/ou predatórias. Cerca de $80 \%$ da população brasileira está vinculada a atividades produtivas que não dependem de altas emissões de carbono e, consequentemente, têm uma taxa de emissões per capita e por unidade de PIB muito inferiores à média dos países desenvolvidos e emergentes, produto fundamentalmente do alto peso da hidroeletricidade na matriz energética. Aproximadamente $20 \%$ da população brasileira está ligada (direta ou indiretamente) à agricultura tradicional, à conversão de uso da terra na fronteira agrícola e à atividade madeireira ineficiente e/ou predatória, e, consequentemente, é responsável por emissões de carbono, per capita, superiores à média dos países emergentes e por unidade de PIB muito superiores à média dos países desenvolvidos e emergentes. (VIOLA, 2002)

\footnotetext{
${ }^{49}$ MINISTÉRIO DA CIÊNCIA E TECNOLOGIA E INOVAÇÃO. Disponível em:

$<$ http://www.mct.gov.br/index.php/content/view/77650.html>. Acesso em: 30 abr. 2013
} 
É nesse ambiente favorável que o Ministério da Ciência e Tecnologia ${ }^{50}$ tem direcionado os esforços na criação de vários programas, a começar pelo álcool. Os projetos relacionados à cogeração de energia a partir do bagaço da cana, os programas de integração energética, de redução de perdas no setor elétrico, de conservação de energia e os projetos de reflorestamento são exemplos de empreendimentos já existentes no Brasil e que podem perfeitamente enquadrar-se como mecanismo de desenvolvimento limpo (MDL).

A atribuição de valor aos resultados dos esforços de redução das emissões ou remoções de GEEs da atmosfera gerou um novo produto de grande aceitação no mercado e constitui-se em uma forma de captação de recursos junto a terceiros. Rocha $(2003$, p. 8) faz o seguinte comentário:

[...] a partir do Protocolo de Quioto, ficou claro que o mercado poderia auxiliar no processo de redução das emissões de GEE, através da proposta de criar um valor transacionável para essas reduções, semelhante aos mecanismos existentes para alguns gases poluidores na Europa e Estados Unidos.

De forma geral, há uma crença de que exista um campo fértil no Brasil para esse novo produto e também de que muitos benefícios econômicos e sociais possam ser esperados. Campos (2004) entende que:

[...] o chamado mercado de crédito de carbono é uma oportunidade para que o Brasil participe do esforço global de combate à mudança do clima, recebendo recursos externos e transferência de tecnologia, promovendo a formação de recursos humanos e a geração de novos e melhores empregos, propiciando benefícios ambientais e mais qualidade de vida. (CAMPOS, 2004, p. ).

Por último, há de salientar que o crescente interesse pelo mercado de carbono. Bittar (2004, p. 5) afirma que diretoria da Deloite Touche Tohmatsu considera que tal crescimento ficou evidenciado com a aprovação pelo governo brasileiro dos dois projetos MDL desenvolvido no país. Os dois são aterros sanitários: Projeto Nova Gerar e Vega, os quais devem “[...] reduzir, em 20 anos, suas emissões em 30 milhões de toneladas equivalentes de gás de carbono, podendo representar no mercado de créditos de carbono um valor de US\$ 150 milhões."

\subsubsection{As simetrias e assimetrias dos mercados de serviços ambientais: água e carbono}

\footnotetext{
${ }^{50}$ MINISTÉRIO DA CIÊNCIA E TECNOLOGIA E INOVAÇÃO. Disponível em:

$<$ http://www.mct.gov.br/index.php/content/view/77650.html>. Acesso em: 30 abr. 2013
} 
Dados ambientais revelam que o Brasil tem 12\% das reservas de água doce do planeta, o que deveria garantir-lhe uma situação privilegiada no cenário mundial. Mas a falta de tratamento adequado para esse bem público de interesse à sobrevivência humana tem tornado o bem cada vez mais escasso. Exploração exagerada, despreocupação com os mananciais, má distribuição, poluição, desmatamento e desperdício são alguns dos fatores que comprovam o descaso com esse recurso ambiental.

A preocupação com a água alcança níveis mundiais, até porque já é considerada um dos recursos naturais que vêm sofrendo escassez provocada pelas mudanças climáticas. Informações divulgadas na conferência mundial sobre água realizada em agosto de 2007, em Estocolmo, revelam que, em 2025, a falta de água atingirá 1,8 bilhões de pessoas no mundo, e que dois terços da população também serão afetados pela escassez do recurso ${ }^{51}$.

Por sua vez, o funcionamento do mercado nas comercializações de bens, de maneira geral, depende de três componentes básicos: os bens levados a mercado; as partes interessadas em vendê-los; e as partes interessadas em comprá-los.

A alocação das águas pelo mercado é justificada na suposição de que o mesmo leva a um uso mais eficiente das águas. O mercado de águas repousa nas mesmas premissas do mercado de bens de uma maneira geral. O modelo supõe que um usuário que possa promover usos privados mais eficientes da água esteja propenso a pagar pelo direito de uso de outro usuário que faça uso menos eficiente. $\mathrm{O}$ valor máximo que o possível comprador pagaria estaria limitado pelo valor incremental de seus lucros com o adicional de água. O preço mínimo que o vendedor estaria disposto a aceitar estaria limitado pelo que deixaria de ganhar com a água cujo direito de uso foi vendido (LANNA, 1994).

Aceitando-se a premissa, devem-se avaliar quais as condições necessárias para que o direito de uso da água possa ser tratado como um bem de mercado. Simpson (1993) apresenta seis pré-requisitos que considera desejáveis para o estabelecimento do mercado de águas. São eles:

\footnotetext{
${ }^{51}$ INSTITUTO CARBONO BRASIL. Disponível em:

$<$ http://www.institutocarbonobrasil.org.br/ecossistemas/agua $>$. Acesso em: 20 abr. 2014.
} 
a) deve existir um produto definido, esse produto deve ser passível de ser controlado, medido e trocado como um bem comercial;

b) deve existir uma demanda para o produto que deve exceder à oferta;

c) o produto deve ser capaz de ser provido quando necessário;

d) o produto deve ter suficiente mobilidade para ser transferido do local de excesso para o local de escassez;

e) deve haver aceitação pela sociedade envolvida de que a livre comercialização do produto é do interesse da sociedade;

f) deve haver mecanismos de administração e regulamentação que assegurem justiça e equidade.

Simpson (1993) não coloca o atendimento rigoroso e total dos seis pré-requisitos como condição indispensável ao estabelecimento do mercado. Todavia, argumenta que o atendimento mais completo aos pré-requisitos citados implica um melhor funcionamento dos mecanismos do mercado.

No texto atual da Lei $\mathrm{n}^{\circ} 9.433$ (BRASIL, 1997), considera-se a água como um recurso limitado, essencial à vida e ao desenvolvimento econômico e como um bem dotado de valor econômico. Daí, decorre a necessidade "de uma legislação sintonizada com essa importância e peculiaridades, pois dela depende a implementação de decisões políticas sobre recursos hídricos para que sejam utilizados racionalmente" (SÁ; CAMPOS, 2001, p. 182).

Assim, em consequência de muitas mudanças ocorridas recentemente no arcabouço legal, há, ainda, diversos pontos de divergência no entendimento das normas do Meio Ambiente e das Águas. A legalidade do mercado de águas é um desses pontos controversos.

Dessa forma, torna-se indiscutível que as águas são bens de domínio dos governos Estadual ou Federal. O uso água se dá mediante outorga concedida pela instituição de governo competente. Há também consenso de que a aplicação do mercado de águas, sem restrições, é incompatível com o arcabouço legal vigente. Há, contudo, algumas situações particulares que podem ser objeto de análise mais profunda para uma decisão sobre sua legalidade, que fogem dos objetivos do estudo.

Em termos comparativos e conclusivos, o mercado do carbono e da água apresentam algumas particularidades simétricas e assimétricas: 
a) no mercado do carbono, o mecanismo foi criado para tentar eliminar diferenças na distribuição de recursos e preservar o meio ecológico com a limitação da quantidade da emissão de Gases de Efeito Estufa (GEEs), com a qual as empresas dos países desenvolvidos, ao realizarem o processo de industrialização, poderiam causar dano ambiental;

b) o mecanismo de desenvolvimento limpo (MDL) objetiva auxiliar os países em desenvolvimento na implantação de tecnologias de recuperação e preservação ambiental e de ajudar os países desenvolvidos a cumprir suas metas de redução de emissões, assim, imputa-se aos maiores poluidores um encargo por comportamento agressivo ao meio ecológico, mas de custo inferior ao que teriam que incorrer para ajustar seu próprio processo operacional a condições adequadas sob o ponto de vista das emissões permitidas;

c) há uma crença de que exista um campo fértil no Brasil para esse novo produto e também de que muitos benefícios econômicos e sociais possam ser esperados;

d) no mercado da água, a falta de tratamento adequado para esse bem público de interesse à sobrevivência humana o tem tornado cada vez mais escasso, principalmente, quando decorrente da exploração exagerada, Despreocupação com os mananciais, má distribuição, poluição, desmatamento e desperdício são alguns dos fatores que comprovam o descaso com esse recurso ambiental;

e) a alocação das águas pelo mercado é justificada na suposição de que o mesmo leva a um uso mais eficiente das águas.

Por fim, o mercado de águas repousa nas mesmas premissas do mercado de bens de uma maneira geral, o modelo supõe que um usuário que possa promover usos privados mais eficientes da água esteja propenso a pagar pelo direito de uso de outro usuário que faça uso menos eficiente e o valor máximo que o possível comprador pagaria estaria limitado pelo valor incremental de seus lucros com o adicional de água. 


\section{METODOLOGIA}

Para alcançar os objetivos propostos, a presente pesquisa fez uso da abordagem qualitativa. Nesse método de abordagem, não há medidas, as possíveis inferências não são estatísticas e procura-se fazer análises em profundidade, obtendo-se até as percepções dos elementos pesquisados sobre os eventos de interesse (CAMPOMAR, 1991). Neste caso, os elementos de interesse são todos aqueles envolvidos na operacionalização dos projetos de pagamento por serviços ambientais de produção de água e captura de carbono.

De acordo com Braga (2007, p.16), “a diferença essencial entre métodos quantitativos e qualitativos está nas distintas maneiras de se ir da parte para o todo". Exatamente por isso, o entendimento moderno do tema é de que "quantitativo" e "qualitativo" designam técnicas de análise de dados que, embora diferentes, podem ser combinadas para produzir respostas mais completas para as questões. Logo, o que dá o caráter qualitativo ou quantitativo não é necessariamente o recurso de que se fará uso para a coleta de informações, mas o referencial teórico/metodológico utilizado para a análise do material coletado (DUARTE, 2004).

O método utilizado para o desenvolvimento da presente pesquisa foi o estudo de caso, considerado como uma indagação empírica que investiga o fenômeno dentro de seu contexto real, ou seja, no contexto da operacionalização dos Projetos de PSA de Produção de Água e Captura de Carbono. Apesar de não proporcionar bases para generalizações, o estudo de caso permite reunir um conjunto de informações, com um grau de detalhamento que facilitará a compreensão do fenômeno real investigado. Utiliza-se esse método para a pesquisa do mercado de serviços ambientais.

Tratou-se de um estudo de casos múltiplos comparativo entre os projetos de PSA envolvendo os serviços ambientais de produção de água e da captura de carbono. A justificativa para a escolha do método é a possibilidade de investigar o fenômeno da operacionalização dos projetos de PSA dentro do seu contexto real, a partir da percepção dos atores envolvidos em cada projeto e de acordo com as suas funções desempenhadas. É sabido que o estudo de caso, com a finalidade de pesquisa, constitui um dos empreendimentos mais desafiadores das ciências sociais. 
O estudo de caso envolve a análise intensiva de um número relativamente pequeno de situações, e, às vezes, o número de casos estudados reduz-se a um, porém é dada ênfase à completa descrição e ao entendimento dos relacionamentos dos fatores de cada situação, não importando os números envolvidos (BOYD; STACH, 1985). Para Yin (2010), a essência de um estudo de caso, a tendência central entre todos os tipos de estudo de caso, é que ele tenta iluminar uma decisão ou um conjunto de decisões: por que elas são tomadas, como elas são implementadas e com que resultado.

A opção pelo método do estudo de caso justifica-se para o estudo pelo fato de nos projetos de PSA de produção de água e captura de carbono existirem custos de transação envolvidos na operacionalização de cada um deles, que podem impedir e/ou dificultar o surgimento espontâneo do mercado de serviços ambientais. Nesse sentido, o estudo e o conhecimento da essência desses projetos, bem como seu estudo comparativo são capazes de auxiliar a responder ao problema de pesquisa: Quais os pressupostos/condições para a criação do mercado dos serviços ambientais? A relação entre custos de transação e a operação realizada em um mercado de serviços ambientais é o principal foco da teoria utilizada na pesquisa.

Para a realização do estudo de caso, foi necessário optar por técnicas de coleta dos dados, utilizando-se das entrevistas. As entrevistas ${ }^{52}$ foram realizadas com os responsáveis de cada um dos projetos de PSA estudados, escolhidos por terem informações técnicas especializadas e por serem capazes de demonstrar conhecimento e domínio sobre tais projetos. Os entrevistados foram considerados suficientemente informados e capazes de proporcionar insights importantes sobre essa matéria. Adicionalmente foram realizadas pesquisas em documentos já publicados pelos participantes e organizadores dos projetos. A maior parte dos documentos de cada PSA de produção de água está disponível em meio eletrônico no site da Agência Nacional de Águas (ANA) ${ }^{53}$, e em páginas eletrônicas dos próprios projetos.

O objetivo em uma entrevista é estabelecer uma relação amigável com o respondente. Existem três fatores que ajudam a aumentar a receptividade do entrevistado: o respondente

\footnotetext{
${ }^{52}$ As entrevistas são conversas guiadas, e não investigações estruturadas, ou seja, embora observada uma linha de investigação consistente, a verdadeira corrente de questões, na entrevista de estudo de caso, será provavelmente fluida, não rígida (YIN, 2010, p. 75). As entrevistas semiestruturadas "são aquelas cujo roteiro é caracterizado por uma série de perguntas abertas, feitas verbalmente em uma ordem prevista, mas na qual o entrevistador pode acrescentar pergunta de esclarecimento" (LAVILLE; DIONNE, 1999, p. 188).

${ }^{53}$ PROGRAMA PRODUTOR DE ÁGUA. Disponível em: $<\mathrm{http} / / /$ produtoragua.ana.gov.br $>$. Acesso em: $07 \mathrm{dez}$ 2012 e em 12 dez. 2013.
} 
deve acreditar que a experiência será agradável e satisfatória; o respondente deve acreditar que responder a essas perguntas é uma coisa importante e que não estará dispersando o tempo dele; e o respondente deve abandonar qualquer desconfiança que possa ter sobre sua participação (COOPER, 2003).

Aos entrevistados, foi solicitado que, se conhecessem os fatos de um assunto técnico específico, assim como as opiniões conclusivas sobre a estrutura e mecanismos de funcionamento dos projetos de PSA, que não tivesse abordado no roteiro, poderiam acrescer essas informações, já que isso poderia facilitar o entendimento, proporcionando uma sondagem muito mais esclarecedora e eficiente. Por se tratar de questões mais estruturadas, foi também utilizada a metodologia de levantamento formal, por corresponder a uma parte relevante do estudo de caso, que deve produzir dados qualitativos necessários como fonte imprescindível de informações (YIN, 2010, p.75).

A maioria entrevistas, agendadas previamente, foi realizada, por indicação dos entrevistados, por meio de comunicação via internet, utilizando-se do aplicativo Skype, com voz e imagem. Essa forma permitiu o estabelecimento de empatia e interesse pelo estudo, o que facilitou a sondagem de questões relevantes e complexas, e significativo volume de respostas e dados, além de contemplar um número desejável de entrevistados nos projetos. As questões foram específicas e elaboradas de modo a permitir que os entrevistados pudessem fazer comentários importantes e que contribuíssem para o atendimento dos objetivos pretendidos. Os métodos de registro podem variar, e como forma de precisar os dados e as informações, neste estudo de caso, foram escritas as respostas recebidas, sendo esse registro realizado à medida de seu recebimento, para que não ocorressem perdas das informações relevantes. O roteiro das entrevistas utilizadas na coleta dos dados de cada um dos projetos de PSA está disposto no Apêndice 1.

Por fim, ao utilizar a fundamentação teórica para o estudo de caso e a análise dos documentos já publicados referentes aos projetos, a pesquisa teve características de pesquisa bibliográfica e documental. As informações obtidas dos projetos estudados de PSA de produção de água e de carbono permitiram a discussão da hipótese central da pesquisa. 


\subsection{Do Protocolo de Estudo de Caso}

O desenvolvimento de um protocolo de estudo de caso é uma etapa fundamental para a investigação e a coleta de dados objeto do trabalho, porque permite manter o alvo sobre o tópico do estudo de caso, e o momento de sua preparação força o pesquisador a antecipar possíveis problemas, que somente poderiam aparecer no decorrer da realização da pesquisa. Yin (2010) destaca que o protocolo de estudo de caso é essencial quando se trata de estudo de casos múltiplos, como no presente estudo, que trata dos PSA de produção de água e de carbono. É uma maneira importante de aumentar a confiabilidade da pesquisa, destinando-se a orientar o pesquisador na realização da coleta de dados, feita por meio das entrevistas.

De maneira geral, o protocolo de estudos de caso, segundo Yin (2010), deve ter as seguintes seções: visão geral do estudo de caso, objetivos e patrocínios do projeto e assuntos do estudo de caso; procedimentos de campo (apresentação de credenciais, acesso aos locais do estudo de caso, linguagem adequada à proteção dos participantes, fontes de dados e advertências de procedimentos); questões de estudo de caso, questões específicas de estudo de caso que o investigador deve ter em mente na coleta de dados, fontes de informações, entre outras; e um guia para o relatório do estudo de caso: esboço, formato para os dados, uso e apresentação de outra documentação e informação bibliográfica.

Tomando por base, o modelo proposto por Yin (2010), para o presente estudo, o protocolo de estudo de caso utilizado para a coleta de dados dos PSA de produção de água e de carbono está disposto no Quadro 7, a seguir.

\section{Quadro 7 - Protocolo de estudos dos casos}

\section{Introdução ao estudo de caso e finalidade do protocolo}

1.2 A teoria utilizada é a da ECT e a unidade de análise é a transação entre os atores envolvidos nos PSA. Em se tratando de PSA, as transações ocorrem entre o produtor (provedor/ofertante) do serviço ambiental e o comprador desse serviço (demandante), com a intermediação de instituições com as mais variadas funções, dentro dos arranjos institucionais criados para implantação dos projetos.

\section{Procedimentos de coleta de dados}

2.1 Os procedimentos para coleta de dados nos PSA de produção de água e de carbono foram pesquisas em documentos e trabalhos já publicados disponíveis de cada projeto e entrevista com os responsáveis pelos projetos. Algumas pesquisas documentais foram obtidas por meio da página eletrônica da Agência Nacional de Água (ANA); outras, por meio das páginas eletrônicas disponíveis de cada projeto.

2.2 Projetos de PSA de Produção de Água Analisados

(i) Projeto Conservador de Águas Município de Extrema (MG)

(ii) Projeto Guandu (RJ)

(iii) Projeto Produtor de Água na Bacia Hidrográfica Piracicaba/Capivari/Jundiaí PCJ (SP)

(iv) Projeto ProdutorES de Água (ES)

(v) Projeto Rio Camboriú (SC) 
2.3 Projetos de PSA de Carbono Analisados

(i) Programa Carbono Seguro

(ii) Programa Suinocultura Sustentável Sadia (3S)

2.4 Coleta de dados

2.4.1 Entrevista com os responsáveis dos Projetos de PSA de Produção de Água e de Carbono - Roteiro de Entrevista constante do Apêndice 1.

2.4.2 Análise dos documentos disponíveis dos Projetos de PSA de Produção de Água e de Carbono

\section{Esboço da análise de cada caso de PSA}

Em cada PSA estudado, foi adotado o mesmo modelo de descrição, contemplando a análise dos seguintes itens:

3.1 Os arranjos institucionais formados para o desenvolvimento do PSA;

3.2 O ambiente institucional onde o PSA foi implantado;

3.3 A função desempenhada pelas instituições e pelos atores envolvidos em cada um dos PSA;

3.4 A metodologia de cálculo utilizada para remuneração do serviço ambiental;

3.5 A fonte de recursos financeiros utilizada para a remuneração dos serviços ambientais;

3.6 A identificação de como é feito o monitoramento da prestação do serviço ambiental;

3.7 As percepções dos atores envolvidos quanto ao desenvolvimento dos PSA, a perpetuação dos projetos e seus efeitos econômicos e ambientais

4. Avaliação do estudo de caso

4.1 Avaliação dos projetos de PSA no sentido de sua evolução para um mercado de serviços ambientais onde ofertantes e demandantes possam transacionar espontaneamente num conceito econômico de mercado.

\subsection{Dos projetos de produção de água e de carbono}

Utilizando o protocolo de estudos de caso proposto para análise do mercado de serviços ambientais de produção de água e de carbono, a partir da ECT, para cada projeto será adotado o mesmo modelo de descrição, identificando os arranjos institucionais formados para o desenvolvimento dos PSAs, o ambiente institucional desenvolvido onde o PSA foi implantado, as instituições envolvidas e suas funções, a metodologia de cálculo para remuneração dos serviços ambientais, as fontes de recursos, o monitoramento da prestação dos serviços e a percepção dos atores envolvidos em cada projeto. Nessa etapa, um dos fatores que permitiram a análise da sustentabilidade do projeto diz respeito à fonte de recursos e à remuneração paga ao produtor (prestador) do serviço ambiental.

O estudo dos custos de transação, no mercado de serviços ambientais, leva à busca de determinar as alternativas de organização da comercialização dos serviços disponíveis na natureza, dentro de uma estrutura institucional criada para esse fim. Nesse sentido, utilizandose a teoria da ECT, a unidade de análise passa a ser a transação entre os atores onde são negociados direitos de propriedade.

Em se tratando de programas de PSA, as transações ocorrem entre o provedor - produtor do serviço ambiental (ofertante) e o comprador desse serviço (demandante), com a intermediação 
de instituições com as mais variadas funções, nos arranjos institucionais criados para implantação dos projetos. Para tanto, o funcionamento dos PSA exige, sob a ótica do direito de propriedade, a existência de diferentes arranjos institucionais e de um ambiente institucional, que sejam capazes de proporcionar a negociação entre ofertantes e demandantes. Nas transações que envolvem os programas de PSA, são evidentes os custos de transação, especialmente aqueles que antecedem a implantação do programa, desde sua formatação até sua implantação, geralmente mais elevados do que aqueles necessários a sua manutenção, que são os custos de monitoramento. Nesse sentido, o estudo da estabilidade do ambiente institucional passa a ser relevante na identificação de arranjos que possam vir a ser considerados adequados para esse mercado.

\subsubsection{Dos projetos de PSA de produção de água}

Os projetos de PSA de produção de água estudados serão aqueles desenvolvidos pelo Programa Produtor de Água, com apoio da Agência Nacional de Águas (ANA) ${ }^{54}$, que tem como foco o estímulo à política de pagamento por serviços ambientais - PSA - voltados à proteção hídrica no Brasil, apoiando, orientando e certificando projetos que visem à redução da erosão e do assoreamento de mananciais hídricos no meio rural, propiciando a melhoria da qualidade, a ampliação, e a regularização da oferta de água em bacias hidrográficas de importância estratégica para o País ${ }^{55}$.

A escolha dos projetos integrantes do Programa Produtor de Água justifica-se por serem projetos em andamento com informações disponíveis para pesquisas; apesar de serem projetos em desenvolvimento, alguns já se encontram consolidados.

Nesse contexto, os pagamentos ocorrem mediante compensação financeira aos agentes (produtores) que, comprovadamente, adotarem, contribuírem ou implementarem práticas para a proteção e recuperação de mananciais, auxiliando a recuperação do potencial de geração de serviços ecossistêmicos e provendo benefícios às bacias hidrográficas e às populações que se

\footnotetext{
${ }^{54}$ PROGRAMA PRODUTOR DE ÁGUA. Disponível em: <http://produtoragua.ana.gov.br>. Acesso em: 07 dez. 2012 e 20 dez. 2013.

${ }^{55}$ PROGRAMA PRODUTOR DE ÁGUA. Disponível em: <http://produtoragua.ana.gov.br $>$. Acesso em: 07 dez 2012 e 20 dez 2013.
} 
abastecem de seus recursos hídricos. Essa remuneração paga aos produtores rurais pela prestação de serviços ambientais é calculada utilizando critérios matemáticos e é definida na lei como apoio financeiro concedido aos proprietários rurais.

Dessa forma, ocorrerá ainda pagamento de recursos por meio da execução de ações para o cumprimento de metas estabelecidas levando em consideração alguns aspectos relevantes, como adoção de práticas conservacionistas de solo, implantação de sistema de saneamento ambiental com a finalidade de dar tratamento adequado ao abastecimento de água, entre outros.

Os PSA de produção de água desenvolvidos pelo Programa Produtor de Água, com apoio da Agência Nacional de Águas (ANA) ${ }^{56}$, compreendem: Projeto Conservador de Águas Município de Extrema (MG); Projeto Produtor de Água na Bacia Hidrográfica Piracicaba/Capivari/Jundiaí PCJ (SP); Projeto Projeto ProdutorES de Água (ES); Projeto Ribeirão Pipiripau (DF); Projeto Rio Camboriú (SC); Projeto Ribeirão João Leite - Goiânia (GO); Projeto Guandu - Rio de Janeiro (RJ); Projeto APA do Guariroba - Campo Grande (MS); Projeto Macaé: Nova Friburgo (RJ); Projeto Rio Tibagi, Ivaí e Pirapó - Apuracarana (PR); Projeto Córrego Feio - Patrocínio (MG); Projeto Ribeirão Guaratinguetá Guaratinguetá (SP); Projeto Rio Rola - Rio Branco (AC); Projeto Rio Taquarussu - Palmas (TO); Projeto Arroio Andreas - Santa Cruz do Sul (RS); Projeto do Rio São Francisco; e Projeto do Rio Doce.

Dos projetos acima identificados, foram escolhidos, por acessibilidade, cinco que possuem mecanismos de funcionamento semelhantes e financiamentos com recursos públicos municipais, estaduais e recursos privados, além da disponibilidade dos dados e do retorno para as entrevistas. São eles: Projeto Conservador de Águas Município de Extrema (MG), Projeto Guandu (RJ), Projeto Produtor de Água na Bacia Hidrográfica Piracicaba/Capivari/Jundiaí PCJ (SP), Projeto ProdutorES de Água (ES) e Projeto Rio Camboriú (SC). Para visualizar a localização do projeto, foi elaborada a Figura 4, que apresenta o mapa do Brasil com a localização dos PSA estudados.

\footnotetext{
${ }^{56}$ PROGRAMA PRODUTOR DE ÁGUA. Disponível em: <http://produtoragua.ana.gov.br $>$. Acesso em: $07 \mathrm{dez}$ 2012 e 20 dez 2013.
} 


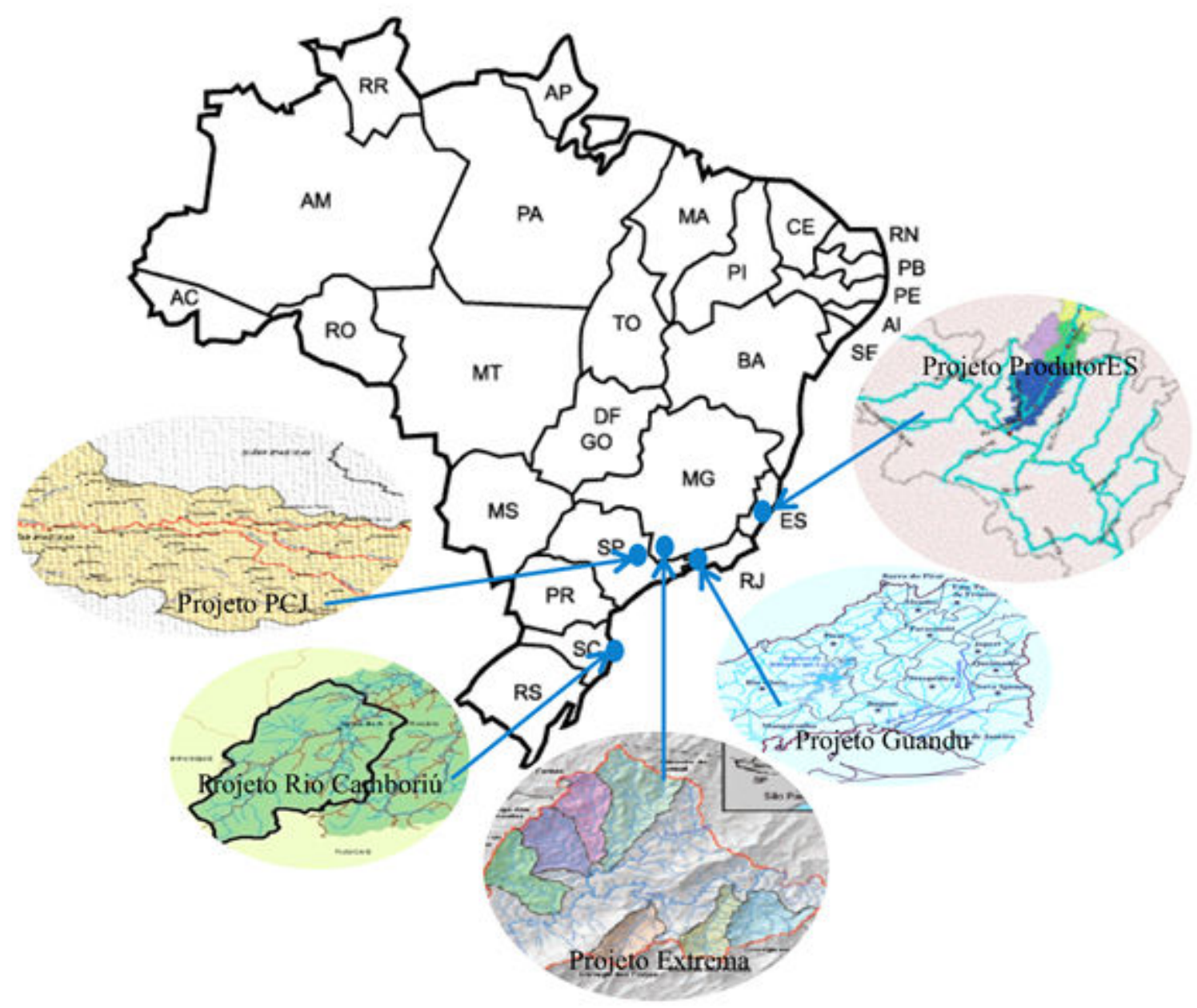

Figura 4 - Localização geográfica dos PSA de produção de água

Em cada um dos projetos estudados, será aplicado o protocolo de estudos de casos indicado neste trabalho e disposto no presente capítulo.

\subsubsection{Dos projetos de PSA de carbono}

Os programas de pagamento por serviço ambiental que contemplam o serviço ambiental de carbono têm por finalidade a manutenção e a preservação das florestas, o estímulo ao estoque e ao sequestro de carbono e às emissões evitadas de gás efeito estufa para atmosfera, advindas do desmatamento e da degradação das florestas. No que se refere à captura de carbono, há de ressaltar que o mercado de comercialização do crédito de carbono teve seu impulso com a assinatura do protocolo de Quioto, que determinou que países desenvolvidos signatários reduzam suas emissões de gases de efeito estufa em 5,2\%, em média, relativas ao ano de 1990, entre 2008 e 2012. Para não comprometer as economias desses países, o protocolo 
estabeleceu que parte dessa redução pode ser feita por negociação com nações por meio dos mecanismos de flexibilização ${ }^{57}$.

Um dos mecanismos de flexibilização é o Mecanismo de Desenvolvimento Limpo (MDL), e o crédito de carbono do MDL é denominado Redução Certificada de Emissão (RCE), ou, em inglês, Certified Emission Reductions (CER). Uma RCE corresponde a uma tonelada de dióxido de carbono equivalente. Dentre as etapas do projeto MDL, destacam-se: a concepção do projeto; o preparo do documento de concepção do projeto (DCP); a validação; a obtenção da aprovação do país anfitrião; o registro; a implementação do projeto; o monitoramento; a verificação e a certificação; e a emissão dos RCEs (crédito de carbono) ${ }^{58}$.

A negociação das RCEs é feita por projeto, com o investidor buscando conhecer todas as suas características, avaliando a capacidade de atingir as reduções de emissões previstas, acompanhando o processo de aprovação da metodologia e de registro no Comitê Executivo do MDL e verificando os benefícios socioambientais associados a ele - as variáveis do projeto que determinam o desenvolvimento sustentável.

Com a ascensão das negociações de crédito de carbono, o Brasil, em 2009, aprovou a Lei ${ }^{\circ}$. 12.187 (BRASIL, 2009), que, além de instituir a política nacional sobre mudança climática, propõe a operacionalização de redução de emissões, por meio de bolsas de mercadorias e futuros, bolsas de valores e balcão organizado, autorizadas pela Comissão de Valores Mobiliários (CVM), onde se dará a negociação de títulos mobiliários de emissões de gases de efeito estufa certificadas.

Os PSA de carbono estudados foram os seguintes: Programa Carbono Seguro, que optou pela modalidade de PSA, ou seja, pelo pagamento aos produtores por manter a floresta em pé, utilizando-se da metodologia do REDD, implantado na região da microbacia do Ribeirão dos Macacos, entre os municípios de Lorena e Guaratinguetá; e Programa Suinocultura Sustentável Sadia (3S), programa de adesão voluntária criada pelo Instituto Sadia por meio da iniciativa da empresa BR Foods ${ }^{59}$.

\footnotetext{
${ }^{57}$ INSTITUTO DO CARBONO BRASIL. Disponível em: $<$ http://www.institutocarbonobrasil.org.br/mercado_de_carbono/protocolo_de_quioto $>$. Acesso em: 15 jan. 2013.

${ }^{58}$ Idem.

${ }^{59}$ Detentora de marcas consagradas como Sadia, Perdigão, Batavo, Elegê, Qualy, Chester, Perdix e Paty, a BRF
} 
Nesse contexto, a remuneração pelos serviços ambientais permite que o proprietário rural receba em dinheiro o equivalente ao carbono estocado na floresta de sua propriedade. Alguns aspectos que precisam ser levados em consideração: a identificação dos financiadores, o preço adequado para a tonelada de $\mathrm{CO} 2$, e a forma de pagamento com seu escalonamento do longo do tempo do contrato. No caso específico de comercialização de créditos de carbono, o recurso oriundo da venda dos créditos somente será repassado aos produtores após o pagamento dos investimentos realizados para a implantação do projeto.

A escolha dos projetos estudados decorreu da disponibilidade de dados para a pesquisa a respeito do funcionamento e do andamento dos Projetos de Carbono, ressaltando que ambos os programas ainda são muito incipientes em seu desenvolvimento. Para visualizar a localização do projeto, foi elaborada a Figura 5 com a localização, no mapa do Brasil, do PSA de Carbono e das localidades em que já foi implantado o Programa 3S.

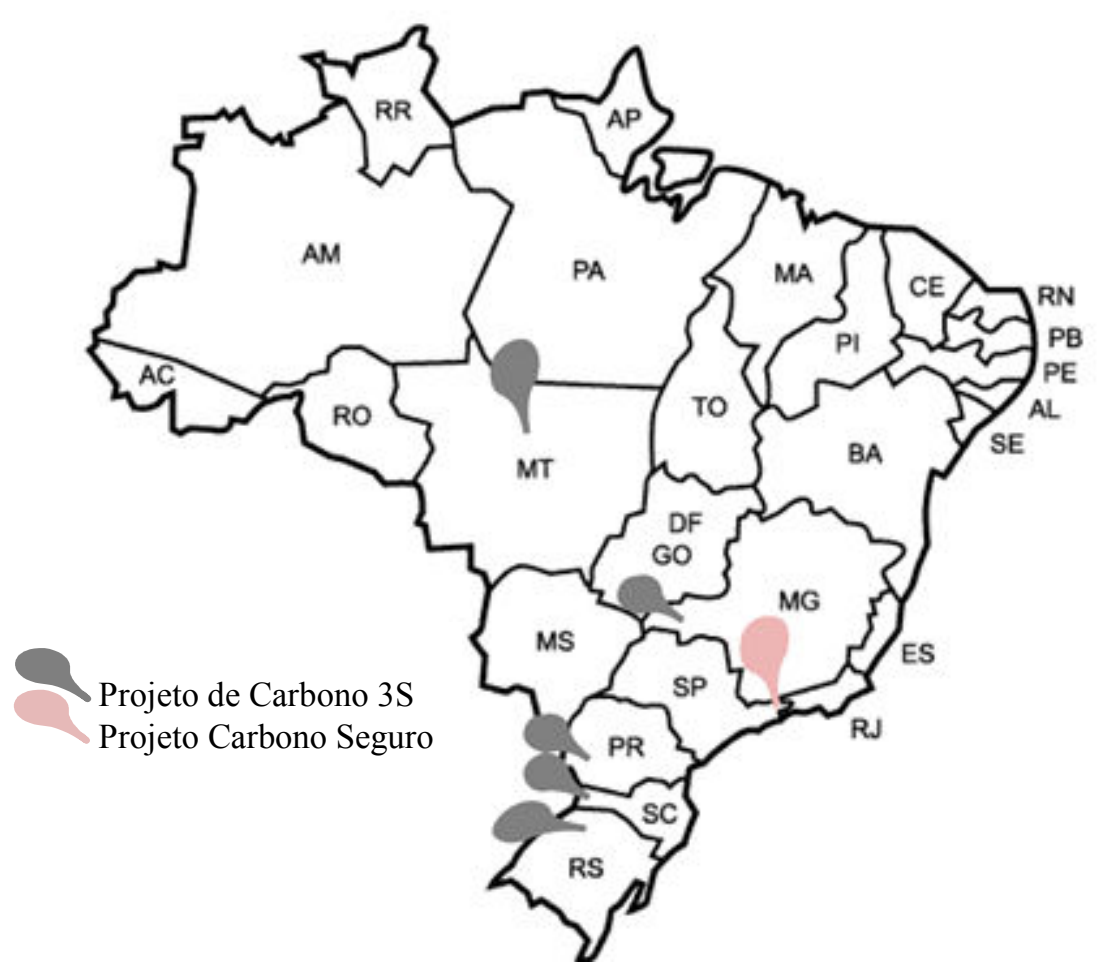

Figura 5 - Localização geográfica do PSAs de carbono e Programa $3 \mathrm{~S}$

\subsection{Modelo de análise dos projetos de produção de água e de carbono}

\footnotetext{
é hoje uma das maiores produtoras de alimentos resfriados e congelados de proteínas do mundo, com um portfólio de mais de cinco mil itens. BRF RELATÓRIO ANUAL DE SUSTENTABILIDADE, 2013. Disponível em: <http://www.brasilfoods.com/ri/siteri/web/arquivos/BRF\%20RA\%20PT\%20140609.pdf>. Acesso em 30 abr. 2014
} 
Levando em consideração o problema, os objetivos, a metodologia, objeto de estudo e a teoria utilizada no presente estudo, foi elaborada a Figura 6 com a visão geral do esquema adotado para o desenvolvimento do trabalho.

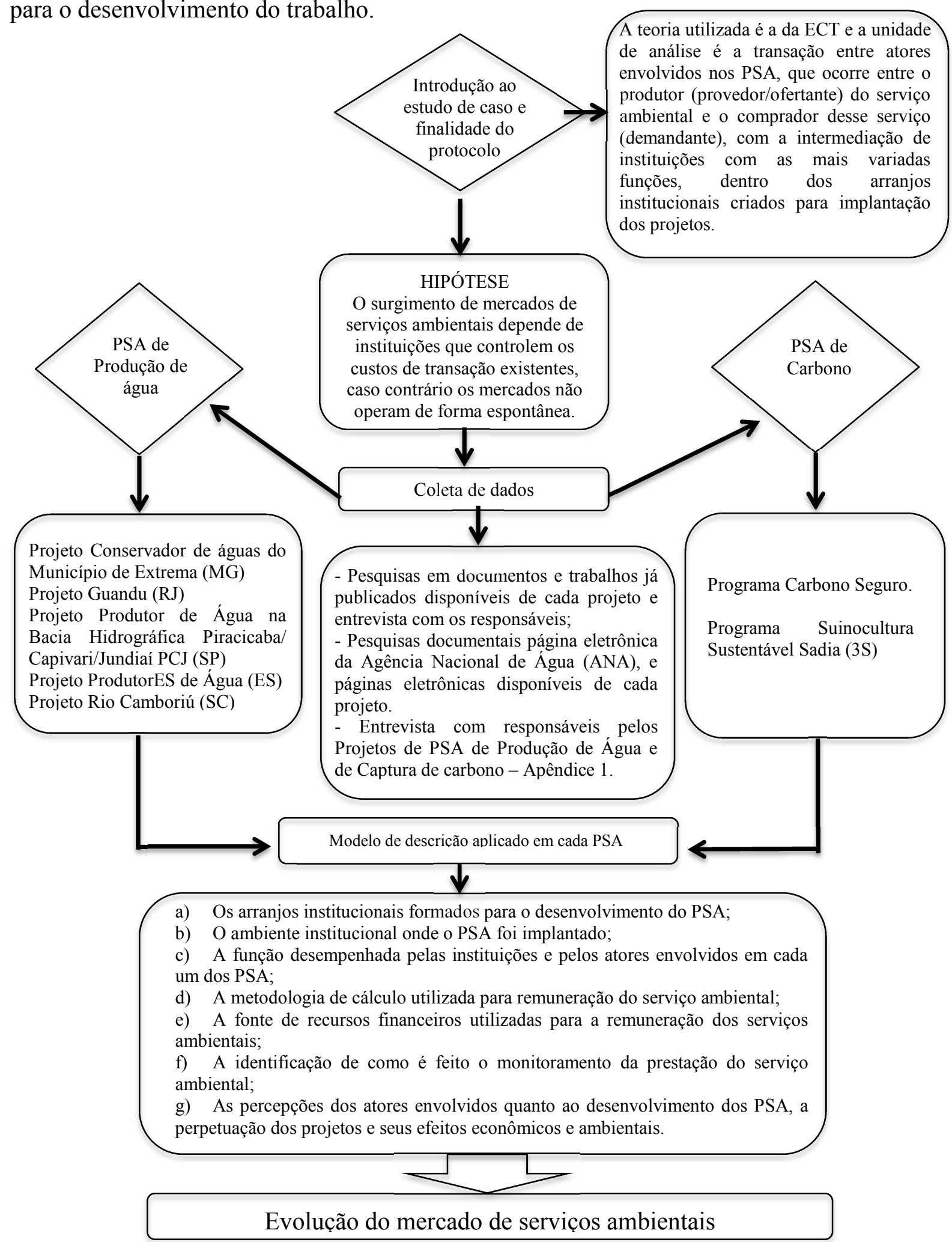

Figura 6 - Visão geral do estudo 
A partir do modelo de descrição realizado em cada PSA, foi elaborado um modelo de análise comparativo para identificar o grau de estabilidade institucional dos projetos de PSA objeto do estudo.

Nesse modelo foram criadas categorias que levaram em consideração o ambiente institucional, os arranjos institucionais, a participação da sociedade civil organizada e o tempo de duração do projeto, conforme demonstrado no quadro 8.

A escolha desses critérios justifica-se porque fornece aos analistas os principais dados e informações suficientes para demonstrar o funcionamento do mercado dos serviços ambientais.

\begin{tabular}{|l|l|l|l|}
\hline \multicolumn{1}{|c|}{ Projetos } & \multicolumn{2}{c|}{ CATTEGORIAS } \\
\cline { 2 - 4 } & Estável & Razoavelmente Estável & Instável \\
\hline Conservador das Águas & & & \\
\hline Produtores de Água e Florestas - Guandu & & & \\
\hline $\begin{array}{l}\text { Produtor de Água na Bacia Hidrográfica } \\
\text { Piracicaba/Capivari/Jundiaí PCJ }\end{array}$ & & & \\
\hline ProdutorES de Água & & & \\
\hline Produtores de Água do Rio Camboriú & & & \\
\hline Carbono Seguro & & & \\
\hline Programa Suinocultura Sustentável Sadia (3S) & & & \\
\hline
\end{tabular}

Serão considerados projetos estáveis aqueles que possuírem: a) legislações específicas criadas para o projeto; b) arranjos institucionais (formais e informais) em que haja participação de entidades públicas e privadas; c) participação de duas entidades da sociedade civil sem fins lucrativos $\left.{ }^{60} ; \mathrm{d}\right)$ estejam em funcionamento há mais de cinco anos.

Os projetos instáveis serão aqueles que: a) não possuírem legislações específicas criadas para o projeto; b) tenham arranjos institucionais (formais e informais) em que haja participação somente de entidades públicas e/ou somente entidade privada; c) tenham a participação de uma ou nenhuma entidade da sociedade civil sem fins lucrativos; d) estejam em funcionamento há menos de dois anos.

Por fim, os projetos considerados razoavelmente estáveis serão aqueles que têm pelo menos duas das características a seguir: a) legislações específicas criadas para o projeto; b) arranjos

\footnotetext{
${ }^{60}$ Classificação no art. 53, da Lei 10.406, 2002, do Código Civil.
} 
institucionais (formais e informais) em que haja participação de entidades públicas e privadas; c) participação de pelo menos uma entidade da sociedade civil sem fins lucrativos. Também os projetos com tempo entre três e cinco anos serão considerados razoavelmente estáveis.

Assim, no próximo capítulo, serão demonstrados os resultados e as discussões acerca dos projetos estudados e a avaliação quanto a sua estabilidade institucional. 


\section{ANÁliSE E DISCUSSÃO DOS PROJETOS DE PAGAMENTOS DE SERVIÇOS AMBIENTAIS}

Neste capítulo, o propósito é analisar empiricamente os estudos de caso de pagamento por serviços ambientais, a começar pelos projetos de produção de água e, posteriormente, os projetos de captura de carbono, observando-se as peculiaridades de cada um, à luz da hipótese de trabalho que norteou a presente pesquisa: o surgimento de mercados de serviços ambientais depende de instituições que controlem os custos de transação existentes, caso contrário, os mercados não operarão de forma espontânea.

Impende observar que no capítulo, inicialmente, foi feita a descrição de cada projeto, contemplando os pontos necessários para análise do mercado de serviços ambientais e tomando como referência a descrição disposta no protocolo de estudos de caso, já apresentado na metodologia ${ }^{61}$. Posteriormente, serão apresentados os resultados e discussões desses projetos.

Após a consolidação dos dados dos projetos de PSA de água e carbono, serão abordados os resultados e discussões, sob o ponto de vista da teoria da nova economia institucional (NEI), abordando o ambiente institucional, os arranjos institucionais com as funções de cada instituição, a metodologia de remuneração dos serviços ambientais, as fontes de recursos, o monitoramento e a percepção dos atores envolvidos. Ainda serão analisados o grau de estabilidade dos projetos de PSA a partir do modelo de análise comparativo dos projetos constante no quadro 7 do capítulo 3 .

Os resultados e discussões dos projetos contribuirão com a resposta aos objetivos gerais e específicos do presente trabalho de pesquisa.

\footnotetext{
${ }^{61}$ (i) Os arranjos institucionais formados para o desenvolvimento do PSA; (ii) O ambiente institucional onde o PSA foi implantado; (iii) A função desempenhada pelas instituições e pelos atores envolvidos em cada um dos PSAs; (iv) A metodologia de cálculo utilizada para remuneração do serviço ambiental; (v) a fonte de recursos financeiros utilizadas para a remuneração dos serviços ambientais; (vi) a identificação de como é feito o monitoramento da prestação do serviço ambiental; (vii) as percepções dos atores envolvidos quanto ao desenvolvimento dos PSA, a perpetuação dos projetos e seus efeitos econômicos e ambientais.
} 


\subsection{Dos Projetos de PSA Produção de Água}

\subsubsection{Projeto Conservador das Águas}

O projeto Conservador das Águas foi instituído pela Lei no 2.100 (EXTREMA, 2005) ${ }^{62}$, e visa à implantação de ações para a melhoria da qualidade e da quantidade de águas no município de Extrema, no Estado de Minas Gerais. Regulamentado em vários aspectos pelo Decreto ${ }^{\circ}$. 2.409 (EXTREMA, 2010), teve como idealizador o gestor ambiental do Departamento de Meio Ambiente do município de Extrema.

A inspiração para a criação do projeto, segundo o gestor, foi o Programa Produtor de Água da Agência Nacional (ANA) ${ }^{63}$ criado em 2001, sendo a iniciativa do poder público municipal, por meio do desenvolvido da atividade junto ao Departamento de Meio Ambiente, que propôs o desenvolvimento do projeto no município.

As microbacias do município de Extrema contribuem para a sub-bacia do Rio Jaguari, que, juntamente com a sub-bacia do rio Atibaia, forma a bacia hidrográfica do rio Piracicaba. Por meio do rio Jaguari, é alimentado o Sistema Cantareira, o maior sistema de abastecimento de água da América do Sul, e fonte de $50 \%$ da água que chega a nove milhões de pessoas da região metropolitana de São Paulo (PEREIRA, 2012). A necessidade do projeto surge exatamente pela importância das sub-bacias localizadas no município de Extrema, em função de sua localização e importância para produção de água e do abastecimento ao Sistema Cantareira $^{64}$, cuja estabilidade foi fortemente posta à prova na primeira metade da década de 2010.

\footnotetext{
${ }^{62}$ Publicada em 21 de dezembro de 2005 pela Prefeitura Municipal de Extrema - MG, cria o Projeto Conservador das Águas, autoriza o executivo a prestar apoio financeiro aos proprietários rurais e dá outras providências. Segundo o gestor, essa foi a primeira lei municipal no Brasil a regulamentar o PSA relacionado à água.

${ }^{63}$ PROGRAMA PRODUTOR DE ÁGUA. Disponível em: <http://produtoragua.ana.gov.br>. Acesso em: 07 dez. 2012.

${ }^{64}$ Consiste na reversão de águas dos reservatórios formados pelos barramentos nos rios Jaguari, Jacareí, Cachoeira e Atibainha, da Bacia do rio Piracicaba, e pelo barramento do rio Juqueri, da Bacia do Alto Tietê. Esse sistema abastecia em 2007 mais de nove milhões de pessoas da Região Metropolitana de São Paulo (RMSP), com uma vazão média anual de 31,3m3/s. Apesar de grande relutância da sociedade civil da região do Sistema Cantareira, o sistema funciona desde 1974 e obteve renovação da outorga em 2004 (AGẾNCIA NACIONAL DE ÁGUAS, 2007, p. 48).
} 
O projeto Conservador das Águas tem a previsão de implantação por sub-bacia hidrográfica, seguindo critérios definidos pelo Departamento de Serviços Urbanos e Meio Ambiente (DSUAMA $)^{65}$. Abrange atualmente sete microbacias hidrográficas do município de Extrema, cuja definição para implantação do projeto levou em consideração os seguintes fundamentos:

a) sub-bacias estudadas e monitoradas por meio do Projeto Água e Vida ${ }^{66}$;

b) sub-bacia com menor cobertura vegetal, sendo priorizado a montante da captação de água do município no rio Jaguari, a partir da seguinte ordem: $1^{\text {a }}$ Das Posses ${ }^{67}$, $2^{\mathrm{a}} \operatorname{Dos}_{\text {Saltos }}{ }^{68}, 3^{\mathrm{a}}$ Dos Forjos ${ }^{69}, 4^{\mathrm{a}}$ Do Juncal $^{70}, 5^{\mathrm{a}}$ Das Furnas ${ }^{71}, 6^{\mathrm{a}}$ Dos Tenentes $^{72}$ e $7^{\text {a }}$ Do Matão ${ }^{73}$;

c) a implantação das atividades do projeto em cada subbacia foi realizado nas propriedades rurais das nascentes para a foz do curso-d'água ${ }^{74}$.

A função do projeto é manter a qualidade dos mananciais de Extrema e promover a adequação ambiental das propriedades rurais, priorizando uma ação mais preventiva do que corretiva. Ao mesmo tempo, o projeto visa garantir a sustentabilidade socioeconômica e ambiental, por meio de incentivos financeiros ao serviço ambiental de produção de água

\footnotetext{
${ }^{65}$ Lei $\mathrm{n}^{\circ} .2 .100$ (EXTREMA, 2005), art. $4^{\circ}$.

${ }^{66}$ Elaborado no ano de 2011, o Projeto Água e Vida - Manejo e Monitoramento em Sub-Bacias Hidrogáficas, cuja meta era a obteção do diagnótico ambiental de Extrema por meio da elaboração de mapas, utilizando imagens de satélite de alta resolução, levantamentos de meios físicos, bióticos e socioeconômicos, monitoramento físico-químico e biológico dos cursos-d'água. Em 2002, foram executados todos os levantamentos propostos e elaborados os relatórios. O município investiu cerca de $\mathrm{R} \$ 200.000,00$ nos levantamentos e diagnósticos ambientais, e os recursos foram provenientes de convênio com o Ministério do Meio Ambiente. De posse do diagnóstico pronto, foi possível partir para a prática e realizar de fato as ações para a adequação ambiental nas propriedades rurais, buscando alianças e entendendo que as negociações com os proprietários rurais deveriam ser muito bem conduzidas, não bastando apenas os mecanismos de comando e controle. (PEREIRA, 2012).

${ }^{67}$ Início em 2007, sendo a área da bacia de 1.254,78 hectares. Bacia com menos de $10 \%$ de cobertura vegetal nativa e todas as propriedades necessitam de ações para adequação ambiental. CONSERVADOR DAS ÁGUAS. Disponível em: <http://extrema.mg.gov.br/conservadordasaguas/CONSERVADOR_PDF_leitura.pdf>. Acesso em: 05 fev. 2014.

${ }^{68}$ Início em 2009 com aproximadamente 4.918,04 hectares. CONSERVADOR DAS ÁGUAS. Disponível em:

$<$ http://extrema.mg.gov.br/conservadordasaguas/CONSERVADOR_PDF_leitura.pdf $>$. Acesso em: 05 fev. 2014.

${ }^{69}$ Início em 2012 com aproximadamente 1.312,5 hectares. CONSERVADOR DAS ÁGUAS. Disponível em: $<$ http://extrema.mg.gov.br/conservadordasaguas/CONSERVADOR_PDF_leitura.pdf $>$. Acesso em: 10 fev. 2014. ${ }^{70}$ Área de 4.229,5 hectares. CONSERVADOR DAS ÁGUAS. Disponível em:

$<$ http://extrema.mg.gov.br/conservadordasaguas/CONSERVADOR_PDF_leitura.pdf $>$. Acesso em: 10 fev. 2014.

${ }^{71}$ Área de 1.622,48 hectares. CONSERVADOR DAS ÁGUAS. Disponível em: $<$ http://extrema.mg.gov.br/conservadordasaguas/CONSERVADOR_PDF_leitura.pdf $>$. Acesso em: 10 fev. 2014. 72 Área de 2.155,22 hectares. CONSERVADOR DAS ÁGUAS. Disponível em:

$<$ http://extrema.mg.gov.br/conservadordasaguas/CONSERVADOR_PDF_leitura.pdf $>$. Acesso em: 10 fev. 2014.

${ }^{73}$ Área de 3.195,55 hectares. CONSERVADOR DAS ÁGUAS. Disponível em: $<$ http://extrema.mg.gov.br/conservadordasaguas/CONSERVADOR_PDF_leitura.pdf $>$. Acesso em: 10 fev. 2014.

${ }^{74}$ Art. $4^{\circ}$ Decreto ${ }^{\circ} .2 .409$, de 2010.
} 
prestado pelos produtores rurais localizados na região de abrangência do projeto, destaca o gestor.

Os produtores rurais que desejam aderir ao projeto devem estar habilitados para tanto e deverão cumprir algumas condições:

a) ter a propriedade rural inserida na sub-bacia hidrográfica trabalhada no projeto;

b) ter a propriedade com área igual ou superior a dois hectares;

c) ter o uso da água regularizado em sua propriedade rural $^{75}$.

Observou-se que no Decreto $n^{0} .1 .703$ (EXTREMA, 2006), a exigência para adesão ao projeto era condicionada ao produtor rural que tivesse o domicílio na propriedade e que se desenvolvesse atividade agrícola com a finalidade econômica na propriedade rural. A partir da vigência do Decreto $n^{\circ} .2 .409$ (EXTREMA, de 2010), essas condições foram alteradas.

Assim, os produtores rurais existentes nas sub-bacias, mas que não se enquadram nas condições determinadas, não poderão participar do projeto, ou seja, essas restrições representam barreiras de entrada no projeto, ainda que prestem serviços ambientais de produção de água.

Os provedores do serviço ambiental de produção de água são os proprietários rurais, a maior parte pequenos produtores de baixa renda, do município de Extrema, localizados nas subbacias abrangidas pelo projeto, que se enquadram nas condições já identificadas e cujas propriedades têm tamanhos médios em torno de 30 hectares, com exploração predominante da pecuária de leite e de corte extensiva de baixa tecnologia. A execução do projeto está a cargo da Prefeitura Municipal de Extrema e, para seu desenvolvimento, o arranjo institucional ${ }^{76}$ adotado e relatado pelo gestor é formado pelos seguintes atores, cada um com funções e ações específicas, a saber ${ }^{77}$ :

a) Prefeitura Municipal de Extrema: atua na gestão administrativa e técnica, na

\footnotetext{
${ }^{75}$ Art. $2^{\circ}$, parágrafo $2^{\circ}$, Decreto no 2.409 (EXTREMA, de 2010), que regulamenta a Lei $n^{\circ} .2 .100$, (EXTREMA 2005).

${ }^{76} \mathrm{O}$ sentido utilizado aqui é aquele entre as unidades econômicas que administram o meio pelo qual tais unidades podem cooperar (...) ou podem fornecer um mecanismo que pode proporcionar uma mudança nas leis ou no direito de propriedade (WILLIAMSON, 1996).

${ }^{77}$ CONSERVADOR DAS ÁGUAS. Disponível em:

$<\mathrm{http}$ //extrema.mg.gov.br/conservadordasaguas/CONSERVADOR_PDF_leitura.pdf $>$. Acesso em: $10 \mathrm{mar}$ 2014.
} 
gestão e recursos financeiros para PSA, na assistência técnica, no mapeamento das propriedades e gerenciamento do projeto, e na criação da unidade de Conservação Ambiental;

b) Secretaria de Meio Ambiente e Desenvolvimento Sustentável (SEMAD) / Instituto Estadual de Florestas (IEF-MG): atua no fornecimento de materiais para cercas e insumos agrícolas, no fornecimento de equipamentos e veículos, recursos financeiros para PSA, no apoio ao processo de comando e controle, no apoio técnico à equipe técnica do município de Extrema;

c) Agência Nacional de Águas: agência reguladora que atua no apoio técnico à equipe técnica do município de Extrema, no monitoramento da qualidade e quantidade da água, e nos recursos para as ações de conservação de solo;

d) The Nature Conservancy (TNC): entidade da sociedade civil que atua no financiamento das ações de plantio, manutenção e cercamento das áreas, no monitoramento da biodiversidade e da comunidade, no fornecimento de equipamentos e caixas para abastecimento de água, no apoio técnico à equipe técnica do município de Extrema, no plantio de espécies nativas com fim econômico, na pegada hídrica ${ }^{78}$ e ecológica;

e) SOS Mata Atlântica: entidade da sociedade civil que atua no fornecimento de mudas de árvores nativas, no apoio técnico à equipe técnica do município de Extrema e na educação ambiental;

f) Comitês das Bacias Hidrográficas dos Rios Piracicaba, Capivari e Jundiaí: empresa pública que atua no financiamento de projetos por meio dos recursos da cobrança pelo uso da água;

g) Bauducco Indústria de Alimentos: empresa privada que atua com o compromisso das águas - pegada hídrica e ecológica;

h) Laticínio Serra Dourada: empresa privada que atua no apoio financeiro aos agricultores inseridos no Projeto Conservador das Águas por meio de bônus de $10 \%$ no preço pago ao leite;

i) Indústria Dalka do Brasil: empresa privada que atua na doação de biodigestores

\footnotetext{
${ }^{78}$ É um indicador do uso da água que considera não apenas o seu uso direto por um consumidor ou produtor, mas, também, seu uso indireto. A pegada hídrica pode ser considerada como um indicador abrangente da apropriação de recursos hídricos, vis a vis ao conceito tradicional e restrito de captação de água. A pegada hídrica de um produto é o volume de água utilizado para produzi-lo, medida ao longo de toda cadeia produtiva. É um indicador multidimensional, que mostra os volumes de consumo de água por fonte e os volumes de poluição pelo tipo de poluição; todas componentes de uma pegada hídrica total são especificadas geográfica e temporalmente. (HOESKSTRA et al, 2011) Disponível em:

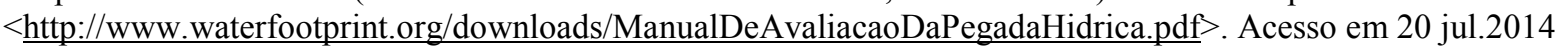


Acqualimp para tratamento de efluentes domésticos das propriedades rurais;

j) Autopista Fernão Dias: empresa privada, sob concessão, que atua no apoio à restauração florestal;

k) Caixa econômica Federal: empresa pública que atua no apoio institucional;

1) Panasonic do Brasil: empresa privada que atua no fornecimento de equipamentos eletrônicos.

O pagamento pelos serviços prestados aos produtores rurais é denominado no projeto como apoio financeiro, sendo concedido aos proprietários rurais habilitados, com previsão legal no Decreto $n^{\circ} 2.409$, (EXTREMA, 2010), art. $2^{\circ}$. O pagamento dos recursos ocorre por meio da execução de ações para o cumprimento de metas estabelecidas:

a) adoção de práticas conservacionistas de solo, com a finalidade de abatimento efetivo da erosão e da sedimentação;

b) implantação de sistema de saneamento ambiental com a finalidade de dar tratamento adequado ao abastecimento de água, tratamento de efluentes líquidos e disposição adequada dos resíduos sólidos das propriedades rurais;

c) implantação e manutenção da cobertura vegetal das áreas de preservação permanente.

Esse apoio financeiro aos proprietários rurais terá como início a assinatura dos termos de compromisso (contratos) e se estenderá por no mínimo quatro anos, podendo ser renovado. $\mathrm{O}$ projeto de cada propriedade terá como ponto de partida o levantamento planimétrico e a elaboração da planta digital do imóvel rural, indicando a situação atual e futura ${ }^{79}$. Os primeiros contratos assinados em 2007 foram todos renovados em 2011 e têm sua vigência prevista até o ano 2015.

O contato com o produtor rural é realizado por meio de visita à propriedade pelos técnicos do Departamento de Serviços Urbanos e Meio Ambiente, momento em que o projeto é apresentado. Havendo adesão pelo produtor rural, é marcada outra visita para demarcação das áreas a serem isoladas/reflorestadas. Nessa visita, colocam-se estacas nos locais onde a cerca irá passar e realizam-se o registro fotográfico e a análise ecológica das áreas de preservação

\footnotetext{
${ }^{79}$ Decreto $n^{\circ} .2 .409$, (EXTREMA, 2010), art. $3^{\circ}$.
} 
permanente. A adesão do produtor será formalizada quando da assinatura do termo de compromisso celebrado entre o proprietário rural e o município de Extrema, com o objetivo de execução das ações e cumprimento das metas. No Anexo 3, está disposto o modelo do termo de compromisso firmado entre o município de Extrema e o produtor rural.

O critério de remuneração pelos serviços ambientais prestados ficou estipulado em 100 Unidades Fiscais de Extrema (UFEX) fixos por hectare por ano ${ }^{80}$, ou seja, o pagamento é feito pela área total do imóvel, visto que o objetivo de adequação ambiental é de toda a propriedade rural. Para a definição desse valor, foi adotado o custo de oportunidade atribuído às propriedades, a partir do valor de arrendamento médio de pastagem por hectare por ano. $\mathrm{O}$ valor de mercado do arrendamento era, em 2005, R\$ 120,00 por hectare por ano, assim, o valor proposto a ser pago foi de R\$141,00, com a utilização da unidade fiscal de Extrema (UFEX) como referência, valor equivalente a 100 UFEX em $2005^{81}$.

O pagamento pelos serviços prestados é realizado em 12 parcelas mensais pagas até o dia 12 de cada mês ${ }^{82}$, por meio de depósito em conta bancária ou cheques nominais, que o produtor rural recebe, mensalmente, na sede da Prefeitura de Extrema. Além disso, os produtores recebem, a cargo dos parceiros, os projetos técnicos, todos os insumos e a mão de obra necessária para o cumprimento das metas.

O monitoramento das propriedades (atualmente 161 contratos) ocorre mensalmente quando é elaborado um relatório até o dia 30 de cada mês, atestando o cumprimento das metas estabelecidas e propondo novas metas para o mês subsequente. O não cumprimento das metas acarreta a interrupção do apoio financeiro. Além disso, a cada seis meses, o Conselho do Meio Ambiente (CODEMA) tem por função legal avaliar o desenvolvimento do projeto e o cumprimento das metas estabelecidas.

No que se refere à fonte de financiamento do projeto, a Lei no 2.100, (EXTREMA, 2005), previu que o Executivo estaria autorizado a prestar apoio financeiro aos proprietários rurais habilitados que aderissem ao projeto, mediante o cumprimento das metas estabelecidas. Além disso, o município também ficou autorizado a firmar convênios com entidades

\footnotetext{
${ }^{80}$ Lei n $^{\mathrm{o}} .2 .100,\left(\right.$ EXTREMA, 2005), art. $4^{\mathrm{o}}$.

${ }^{81}$ Em 2013, 100 UFEX eram equivalentes a R\$ 210,00; em 2014, 100 UFEX são equivalentes a R\$221,00.

${ }^{82}$ Decreto $n^{\circ} .2 .409$ (EXTREMA, 2010), art. $6^{\circ}$.
} 
governamentais e da sociedade civil com a finalidade de apoio técnico e financeiro ao projeto, o que ocorreu com a formação do arranjo institucional apresentado para o desenvolvimento do projeto. Da mesma forma ficou autorizado o estabelecimento de verbas próprias no orçamento do município para o custeio dos gastos com o projeto Conservador das Águas.

Na primeira sub-bacia, a Das Posses, a prefeitura de Extrema ficou responsável pelo pagamento dos serviços ambientais aos produtores; as demais entidades ficaram responsáveis pelos investimentos nas demais ações. Na segunda bacia, a Do Salto, foi obtido apoio financeiro do Estado de Minas para pagamento dos serviços ambientais aos produtores para 2.000 ha. É visível nesse projeto que a prefeitura municipal de Extrema e a Secretaria de Meio Ambiente e Desenvolvimento Sustentável (SEMAD) do Estado têm sido as principais fontes de financiamento para o pagamento aos produtores. Os demais envolvidos, como a Agência Nacional de Águas (ANA), a TNC e outros atores, também fazem suas contribuições. O Comitê da Bacia Hidrográfica dos Rios Piracicaba/Capivari/Jundiaí - PCJ, com recursos oriundos da cobrança federal pelo uso de recursos hídricos, também contribui com recursos para o projeto. Cabe observar que o orçamento é um instrumento de planejamento pelo qual os entes federativos estimam receitas e fixam despesas para determinado exercício, encaminhando-o para aprovação do Legislativo, de forma que passa a viger na forma da lei pelo período que corresponde. Nesse sentido, uma vez aprovados pelo orçamento, os recursos reservados estão autorizados até o limite, e este deverá ser anualmente aprovado. Portanto o orçamento precisa ser aprovado anualmente, já que é um recurso direto da municipalidade.

De acordo com o Orçamento das Despesas do ano de $2014^{83}$ do Município de Extrema, a estimativa de gastos para o Projeto Conservador das Águas é de R\$2.620.000,00, desse montante, R\$ 760.000,00 são destinados para pagamento a produtores em 2014.

A avaliação do projeto pelo gestor é muito positiva já que houve considerável aumento (de mais de $10 \%$ ), dobrando a cobertura vegetal nativa (sub-bacia de Posses). Na sub-bacia do Salto, as áreas protegidas foram ampliadas em $20 \%$, atingindo mais de $30 \%$ da cobertura com vegetação. Até a presente data, o projeto já trabalhou com as bacias do Salto, das Posses e dos Forjos, esta última teve as primeiras contratações em 2012.

Os dados da evolução financeira e de áreas preservadas do Projeto Conservador das Águas

\footnotetext{
${ }^{83}$ PORTAL DA TRANSPARÊNCIA. Disponível em: $<$ https://extrema-mg.portaltp.com.br $>$. Acesso em: 05 abr. 2014.
} 
estão demonstrados na Tabela 1.

Tabela 1 - Demonstrativo da evolução da área sob contrato de PSA Conservador das Águas

\begin{tabular}{c|c|c|r}
\hline Ano & $\mathbf{N}^{\mathbf{0}}$ de Contratos & Área (hectares) & \multicolumn{1}{c}{ Valor PSA Pago (R\$) } \\
\hline 2007 & 21 & 451 & $16.165,00$ \\
\hline 2008 & 14 & 306 & $226.101,00$ \\
\hline 2009 & 26 & 674 & $340.529,00$ \\
\hline 2010 & 15 & 894 & $419.462,00$ \\
\hline 2011 & 24 & 523 & $557.106,00$ \\
\hline 2012 & 44 & 2.356 & $631.881,00$ \\
\hline 2013 & 17 & 415 & $\mathbf{2 . 2 9 8 . 1 0 2 , 0 0}$ \\
\hline TOTAL & $\mathbf{1 6 1}$ & $\mathbf{5 . 6 1 9}$ & \\
\hline
\end{tabular}

FONTE: CONSERVADOR DAS ÁGUAS. Disponível em:

$<$ http://extrema.mg.gov.br/conservadordasaguas/CONSERVADOR_PDF_leitura.pdf $>$. Acesso em: 30 mar 2014.

Essa evolução está representada no Gráfico 1, que demonstra a evolução acumulada das áreas sob contrato e dos valores pagos em relação à adesão de novos contratos. O total das áreas cobertas por esses 161 contratos (demonstrados em valores absolutos) é de 5.619 hectares (demonstrados acumulados). O valor do pagamento total de $\mathrm{R} \$ 2.298 .102,00$, para efeitos de representação gráfica, está demonstrado acumulado à razão de 1000 em escala.

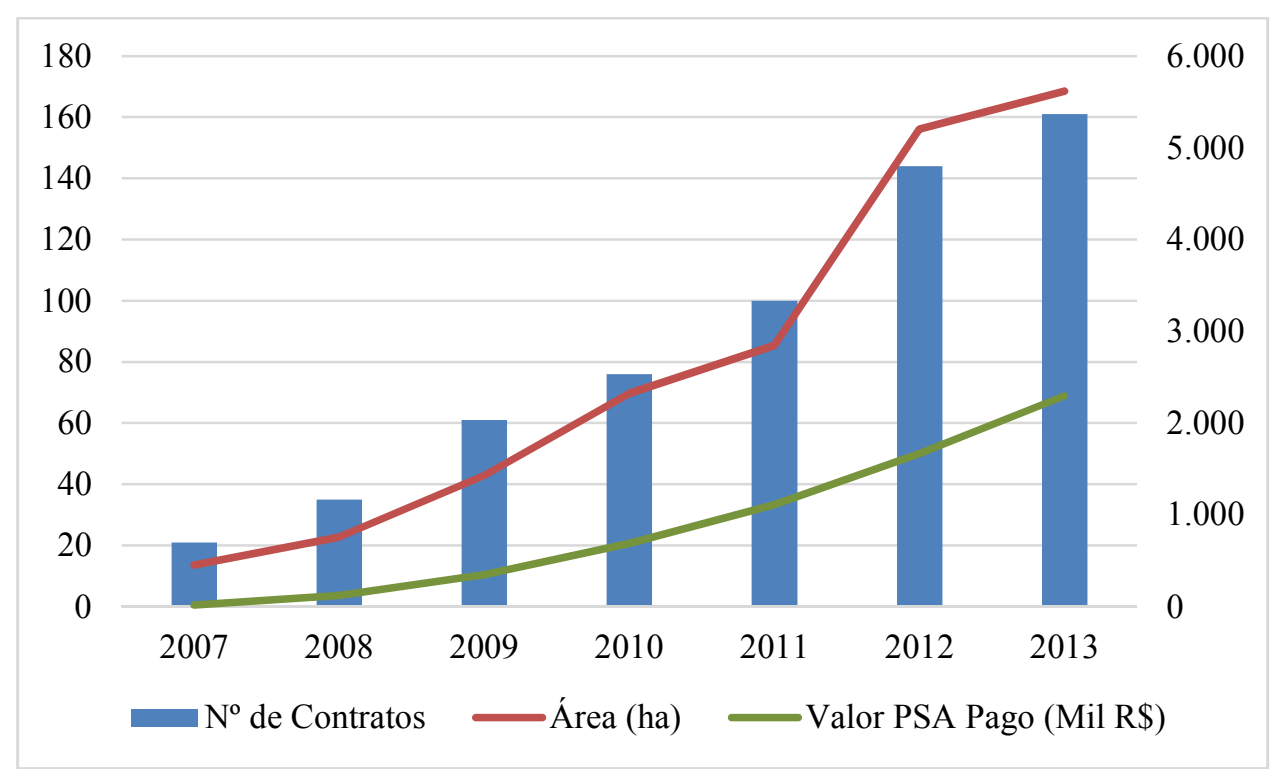

Gráfico 1 - Evolução do Projeto Conservador das Águas

Mesmo que a evolução da adesão de contratos não seja crescente, no acumulado das áreas, pode-se observar que houve uma crescente, na quantidade de área contratada, gerando assim o aumento de valores pagos pelos contratos. 
De todo esse período, o gestor relatou que houve apenas um problema de suspensão de pagamento da remuneração pelo serviço ambiental em uma propriedade, e foi um caso isolado de entrada de gado de dentro de restauração florestal, acontecido em 2007. Após a resolução do problema, o pagamento pelo serviço voltou a ser realizado normalmente. O gestor ainda relatou que não foi percebido nenhuma valorização imobiliária por força da adesão ao projeto.

A maior dificuldade relatada pelo gestor do projeto foi que, em sua origem, não havia no Brasil outro projeto de PSA em execução, sendo necessário desenvolver toda a metodologia e as rotinas, e, ao mesmo tempo, convencer as pessoas e as instituições de que o projeto tinha chance sucesso. Destacou, ainda, que os principais problemas encontrados durante a implementação foram a consistência dos projetos técnicos, a adoção de uma metodologia adequada e a capacitação de pessoas envolvidas na execução do projeto. Ressaltou que as regras não foram mudadas, pois foram pensadas para serem flexíveis, mas os métodos foram mudados para absorver novos conhecimentos, principalmente, nas técnicas de restauração florestal e necessidades nas negociações com os proprietários rurais.

A população do município de Extrema também foi beneficiada, uma vez que o projeto foi totalmente absorvido pela sociedade. O projeto gerou mais de 30 empregos diretos, além da capacitação de mão de obra para restauração florestal, práticas de conservação de solo e saneamento ambiental. Por fim, destacou que os produtores rurais estão satisfeitos com o projeto. Se no início era necessário insistir com os produtores rurais para obter adesão ao projeto, hoje eles próprios estão dispostos a participar. Da mesma forma, é perceptível a contribuição do aumento de renda dos produtores, já que os recursos repassados até 2013 totalizaram R\$ 2.198.102,00. "Temos orgulho do pioneirismo de Extrema que incentivou outros projetos de PSA", afirma o gestor.

\subsubsection{Projeto Produtores de Água e Florestas - Guandu}

O projeto Produtores de Água e Floresta - Guandu teve sua criação em maio de 2009, por meio da assinatura do termo de Cooperação Técnica (TCT) entre o Instituto Estadual do Ambiente (INEA), órgão vinculado à Secretaria do Ambiente (SEA), o Instituto de Conservação Ambiental (TNC) do Brasil, o Comitê da Bacia Hidrográfica do Guandu, o 
município de Rio Claro e o Instituto Terra de Preservação Ambiental, com a interveniência do Estado do Rio de Janeiro, tendo sua publicação no Diário Oficial do Estado do Rio de Janeiro, em 18 de agosto de 2009. Nesse termo de cooperação, ficou estabelecido que a atuação no projeto será de forma compartilhada e integrada com a criação de uma Unidade Gestora do Projeto (UGP) ${ }^{84}$. O prazo de duração do termo é de 60 meses a contar da data da publicação no Diário Oficial, portanto, a sua vigência é até o dia 18 de agosto de 2014.

O projeto teve como origem o trabalho realizado em conjunto, a partir de agosto de 2007, entre a sociedade civil organizada, o governo do estado do Rio de Janeiro, o Comitê da Bacia Hidrográfica do Rio Guandu e os municípios da bacia do Guandu. Nesse trabalho ficou estabelecido que o mecanismo a ser testado teria como tema principal a produção de águas e conservação de florestas visando à manutenção e ao aumento da quantidade de recursos hídricos da bacia do Guandu, com foco na melhoria dos indicadores de qualidade, na redução de sedimentação, no aumento da cobertura florestal associada à adequação ambiental de propriedades rurais e na geração de emprego e renda na bacia (PEREIRA et al, 2012).

Dentre os objetivos do projeto, destacam-se:

a) gerar sustentabilidade socioeconômica e ambiental na sub-bacia do Rio das Pedras e estender para as áreas prioritárias da Bacia do Rio Guandu;

b) difundir o conceito de pagamento por serviços ambientais e promover sua replicação;

c) meta de conservação de 3.450 hectares e de restauração de 275 hectares.

Além disso, o projeto propõe-se a aplicar o modelo provedor-recebedor por meio de um sistema de pagamentos por serviços ambientais, incentivando, mediante compensação financeira, os agentes que, comprovadamente, adotarem, contribuírem ou implementarem práticas para a proteção e a recuperação de mananciais, auxiliando a recuperação do potencial de geração de serviços ecossistêmicos, provendo benefícios às bacias hidrográficas e às populações que se proveem de seus recursos hídricos.

\footnotetext{
${ }^{84}$ Cláusula segunda do Termo de Cooperação Técnica assinado em maio de 2009; desde sua criação são mantidos calendários de reuniões trimestrais, cada um cumprindo com suas atribuições previamente estabelecidas e mantendo espaço de discussão e construção de iniciativas voltadas ao tema de pagamento por serviços ambientais, sempre com as reuniões pautadas por registros em atas contendo as deliberações realizadas. Foram estabelecidos procedimentos padrões a UGP, como as relacionadas ao monitoramento e ao pagamento pelos serviços prestados.
} 
A área foco do projeto está localizada em Lídice, distrito do Município de Rio Claro - RJ, e abrange uma área total de 5.227 hectares, compreendendo as principais nascentes do Rio Piraí. Este manancial é responsável por até $15 \%$ dos recursos hídricos disponíveis no sistema Guandu, destacando-se, igualmente, pela alta relevância para a biodiversidade da Mata Atlântica, sendo zona núcleo da Reserva da Biosfera, entorno do Parque Estadual Cunhambebe e território da Área de Proteção Ambiental do Alto Piraí, manancial responsável por até $15 \%$ dos recursos hídricos disponíveis no Sistema Guandu.

A bacia hidrográfica do Rio Guandu tem significativa relevância, pois é fonte gestora dos recursos hídricos para abastecimento da região metropolitana do Rio de Janeiro, abastecendo aproximadamente 11,8 milhões de habitantes (IBGE, 2010).

Os gestores do projeto afirmam que a Bacia do Guandu é responsável por cerca de $80 \%$ do abastecimento de água e $25 \%$ da geração de energia elétrica para a região metropolitana do Rio de Janeiro, onde beneficia aproximadamente sete milhões de pessoas, e tem como instância de gestão um dos mais atuantes comitês de bacia hidrográfica em todo o Brasil, o Comitê Guandu, o que justifica o empenho para a implantação e o sucesso de um programa de PSA para produção de águas.

$\mathrm{O}$ arranjo institucional ${ }^{85}$ para o desenvolvimento do projeto está composto das seguintes instituições, cada uma delas com funções e atribuições específicas, a $\operatorname{saber}^{86}$ :

a) Município de Rio Claro: atua no incentivo, no apoio e na difusão da adesão dos proprietários rurais ao projeto; disponibiliza recursos humanos com capacitação técnica necessária para o cumprimento das obrigações assumidas; designa servidores municipais para a execução de atividades instrumentais de manutenção e implementação de plantios e cercas; e disponibiliza técnico extensionista rural para assistência aos proprietários participantes do projeto. Cedeu o imóvel ${ }^{87}$ para sediar as atividades de coordenação e desenvolvimento do projeto;

\footnotetext{
${ }^{85} \mathrm{O}$ sentido utilizado aqui é aquele entre as unidades econômicas que administram o meio pelo qual tais unidades podem cooperar (...) ou podem fornecer um mecanismo que pode proporcionar uma mudança nas leis ou no direito de propriedade (WILLIAMSON, 1996).

${ }^{86}$ Algumas atribuições das instituição tem previsão na cláusula terceira do termo de cooperação técnica assinado em maio de 2009.

${ }^{87}$ Associação de Quilombo Alto da Serra.
} 
b) Instituto Estadual do Ambiente (INEA): órgão do governo estadual do Rio de Janeiro que atua no apoio, na potencialização, na implementação e na difusão do projeto; realiza contratações pertinentes ao cumprimento dos projetos aprovados pelo Guandu e relativos a ele; celebra com os particulares os ajustes específicos para destinar ao projeto os recursos necessários à realização dos serviços aprovados pelo Comitê Guandu que não possam ser executados diretamente pela autarquia; fornece as mudas, os insumos e as cercas necessárias à restauração das áreas prioritárias desflorestadas, de acordo com o plano de trabalho; e fiscaliza o cumprimento das obrigações assumidas pelos demais partícipes.

c) Instituto Terra de Preservação Ambiental (ITPA): entidade da sociedade civil que atua na elaboração do projeto e seus respectivos planos de trabalho, na coordenação e na execução local do projeto, no aprimoramento dos estudos e no diagnóstico detalhado de abrangência do projeto; presta assistência aos proprietários e acompanha a implementação nas propriedades-alvo do projeto; sistematiza e disponibiliza as informações necessárias ao monitoramento das atividades e à consolidação dos planos de trabalho anuais; e realiza atividades de secretaria-executiva da UGP;

d) The Nature Conservancy (TNC): entidade da sociedade civil que atua no acompanhamento e na prestação de assistência para elaboração e implementação do projeto; contribui para o fortalecimento institucional, envidando esforços para a captação e o aporte de recursos na realização de pesquisas, restauração e implementação de ações de conservação;

e) Associação Pró-Gestão da Bacia Hidrográfica do Rio Paraíba do Sul (AGEVAP) ${ }^{88}$ : agência de bacia hidrográfica que tem como função firmar convênios com o município de Rio Claro para a transferência dos recursos oriundos da arrecadação pela cobrança da água; no período de 2009 a 2011, teve a função de contratar e efetuar o pagamento aos produtores rurais; responsável pelo

\footnotetext{
${ }^{88}$ Criada em 20 de junho de 2002, foi constituída, inicialmente, para o exercício das funções de SecretariaExecutiva do Comitê de Integração da Bacia Hidrográfica do Rio Paraíba do Sul (CEIVAP), desenvolvendo também as funções definidas no Art. 44 da Lei $n^{\circ} .9 .433$ (BRASIL, 1997), que trata das competências das chamadas Agências de Água, ou Agências de Bacia, como são mais conhecidas, principalmente no que se refere à elaboração do Plano de Recursos Hídricos e à execução das ações deliberadas pelo Comitê para a gestão dos recursos hídricos da Bacia. A partir da edição da Medida Provisória $\mathrm{n}^{\circ}$ 165, posteriormente convertida na Lei $\mathrm{n}^{\circ}$. 10.881 (BRASIL, 2004), a AGEVAP pôde, por meio do estabelecimento de Contrato de Gestão com a Agência Nacional de Águas (ANA), assumir as funções de uma Agência de Bacia, que são, essencialmente, receber os recursos oriundos da cobrança pelo uso da água bruta na bacia e investi-los segundo o plano de investimentos aprovado pelo Comitê da Bacia.
} 
lançamento dos editais anuais;

f) Comitê das Bacias Hidrográficas do rio Guandu: empresa pública que atua no financiamento dos recursos para o pagamento aos produtores, oriundo da arrecadação e cobrança pelo uso da água;

Para a formatação e a construção do projeto, foi realizado um estudo de reconhecimento da estrutura fundiária, social e agrícola do local, o que possibilitou a identificação da cobertura vegetal, áreas de preservação e reservas legais no território da bacia. A partir desse estudo, foi possível identificar que, do universo de 121 propriedades, 14\% têm menos de 5 hectares; $17 \%$, entre 5 e 7 hectares; $27 \%$, entre 50 e 100 hectares; e apenas 5\% das propriedades têm mais de 100 hectares. Grande parte dos proprietários têm baixa escolaridade, e apenas 50\% das propriedades estão documentadas definitivamente em nome dos proprietários atuais. $\mathrm{O}$ estudo também revelou uma baixa intensidade de uso do solo, com reduzida capacidade de geração de renda nas propriedades e com poucas oportunidades de trabalho (PEREIRA et al, 2012).

Para que fosse possível a implementação e a operacionalização do projeto de PSA na bacia, foi aprovado a Lei $n^{\circ} .514^{89}$ (RIO CLARO, de 2010), pela Câmara Municipal de Rio Claro, cuja regulamentação se deu por meio do Decreto 931, (RIO CLARO, 2011). Além disso, foi identificado que o Comitê das Bacias Hidrográficas dos rios Guandu, da Guarda e GuanduMirim aprovou a Resolução $\mathrm{n}^{\circ}$ 85, de 2012, com a criação do Programa de Pagamento de Serviços Ambientais (POS-PSA) na Região Hidrográfica II do Guandu. Isso demonstra a formação de um ambiente institucional para a implantação do PSA nessa bacia.

O pagamento pelos serviços prestados aos produtores rurais foi denominado no projeto como apoio financeiro concedido aos proprietários rurais habilitados, e tem previsão legal no art. $2^{\circ}$ da Lei $n^{\circ}$. 514, (RIO CLARO, 2010), que autorizou o Poder Executivo a prestar esse apoio financeiro aos proprietários rurais habilitados que aderirem ao projeto. O Decreto $n^{\circ}$ 931, RIO CLARO, 2011), determinou, em seu art. $2^{\circ}$, que a fonte da receita para o pagamento do apoio financeiro deverá ser oriunda da receita do repasse do ICMS, de que trata a Lei $\mathrm{n}^{\mathrm{o}}$. 5.100, (RIO CLARO, 2007), ressalvando que os pagamentos serão aos proprietários das reservas de preservação permanente legalmente constituídas e situadas no município de Rio Claro - RJ.

\footnotetext{
${ }^{89}$ Art. $1^{\circ}$ : Fica criado o Projeto Produtor de Águas e Florestas, que visa à implantação de ações para a melhoria da qualidade e quantidade das águas e à conservação da biodiversidade no Município de Rio Claro.
} 
A execução do mecanismo de contratação e pagamento inicialmente ocorreu por meio da Associação Pró-Gestão da Bacia Hidrográfica do Rio Paraíba do Sul (AGEVAP); a partir de 2012, passou a sê-lo pela Prefeitura Municipal de Rio Claro, com contratos de transferência de recursos firmados entre a AGEVAP e a Prefeitura de Rio Claro, dentro da disponibilidade orçamentária deliberadas pelo Comitê Guandu.

Os recursos disponibilizados para o pagamento direto aos proprietários participantes do projeto - oriundos da arrecadação com a cobrança pelo uso dos recursos hídricos da bacia, de acordo com os trâmites da política estadual de recursos hídricos do Rio de Janeiro - foram garantidos pelo Comitê Guandu ${ }^{90}$. Para o primeiro ano do projeto (2009), foram liberados R\$ $40.000,00$, e mais R $\$ 1.000 .000,00$, para o período de 2011 a 2015, sendo de R $200.000,00$ o valor máximo a ser aplicado por ano. O gestor destacou que no primeiro ano do projeto, em 2010, em função dos trâmites necessários à liberação dos recursos do Comitê do Guandu, o Instituto Terra de Preservação Ambiental teve de assumir o compromisso de garantir os recursos aos produtores rurais para que o projeto não caísse em descrédito junto aos participantes.

Os provedores do serviço ambiental de produção de água são os proprietários rurais habilitados, localizados no município de Rio Claro, que aderirem ao projeto a partir do cumprimento de metas nas seguintes modalidades:

a) conservação de remanescentes florestais: compreende a manutenção das áreas florestais nativas da Mata Atlântica, com sua valorização como área geradora de benefícios socioambientais extrapropriedade;

b) restauração ambiental: compreende a proteção de áreas de mananciais e nascentes promovendo a gradativa alteração da cobertura do solo, amenizando os processos erosivos e visando à recuperação da floresta nativa.

Para que possa pleitear os recursos do PSA, o produtor, além de ter sua propriedade na Bacia Hidrográfica RGH II - Guandu, deverá submeter proposta a partir dos editais anuais ${ }^{91}$

\footnotetext{
${ }^{90}$ Resolução 042 , de dezembro de 2009, art. $1^{\text {o }}$ - Aprovou a aplicação dos recursos financeiros, arrecadados na conta do FUNDRHU ao projeto Produtores de Água.

${ }^{91}$ Art. $4^{\circ}$ Decreto 931, (RIO CLARO, 2011).
} 
lançados pela AGEVAP, descrevendo as ações de conservação e restauração, observados os padrões de conteúdo e formato estabelecidos. Também está estabelecido que o produtor rural deverá disponibilizar em sua propriedade no mínimo $25 \%$ de área sem cobertura vegetal para restauração. Esse percentual influencia diretamente a valoração do serviço ambiental prestado, ou seja, terá melhor pagamento aquele proprietário que disponibiliza maiores percentuais de áreas prioritárias para restauração.

A valoração do serviço ambiental prestado é baseada na área contratada e na porcentagem de restauração em área prioritária, identificada como classe de adesão, cujo cálculo utiliza como valor de referência o custo de oportunidade local ( $\mathrm{R} \$ / \mathrm{ha} / \mathrm{ano})$ fixado para o município de Rio Claro, associado a quatro parâmetros: áreas de conservação e restauração (em ha), nível de prioridade para a produção de água na bacia, estágio de sucessor dos remanescentes em conservação e contexto geo

de proximidade ou inclusão em unidades de conservação.

A Lei $n^{\circ}$ 514, (RIO CLARO, 2010), em seu art. $4^{\circ}$, daquele município, determina que o valor de referência para pagamentos do serviço ambiental será de $\mathrm{R} \$ 10,00$ (dez reais) por hectare por mês, limitando-se a uma área de no máximo 100 hectares.

Os pagamentos aos produtores são realizados em duas parcelas por ano por meio de cheques nominais, expedidos pelo Fundo Municipal de Desenvolvimento do Meio Ambiente de Rio Claro (FUMDEMA), ou depósitos em conta, e são realizados somente após a avaliação das atividades desenvolvidas, por meio de relatórios de implantação e laudo de vistoria em que são observados o estado geral e os cuidados com as ações implantadas, ou seja, após o monitoramento da prestação dos serviços ambientais contratados.

Os contratos, realizados entre produtores e a prefeitura municipal de Rio Claro, formalizam as condições da prestação dos serviços, determinando as metas e as responsabilidades tanto do contratante como do contratado. No momento da realização do contrato, são exigidos documentos relativos à propriedade e aos proprietários responsáveis pelo contrato. Os contratos têm vigência de 12 meses, prorrogáveis por igual tempo. Segundo o gestor, desde o início do projeto (2009 até o ano de 2013), dos 62 produtores contratados, houve somente a rescisão de cinco contratos, em função de morte do produtor rural contratado. No Anexo 4, encontra-se um modelo de contrato firmado entre a Prefeitura de Rio Claro e uma produtora 
rural.

O projeto, além do monitoramento pela prestação do serviço, ainda conta com um sistema de monitoramento ambiental de forma a possibilitar acúmulo de informações sobre a bacia, ou seja, são monitorados diariamente precipitação e deflúvio; mensalmente, a vazão; bimestralmente, é realizada a coleta de campo, que analisa 11 parâmetros de qualidade; e, periodicamente (três a cinco anos), está prevista a atualização do mapeamento e a avaliação da cobertura florestal da microbacia.

O acompanhamento do desenvolvimento do projeto é realizado por meio da gestão dos indicadores quantitativos de: número de proprietários contratados (baseado em contratos assinados), hectares conservados (baseado em contratos assinados), hectares em restauração (baseado em contratos), pagamentos por período realizados aos provedores contratados, pagamentos acumulados realizados aos provedores contratados, recursos captados para restauração florestal, recurso destinado para PSA (Comitê Guandu). A partir desses indicadores, em junho de 2013, os últimos dados atualizados fornecidos pelo gestor encontram-se na Tabela 2.

Tabela 2 - Saldo de Indicadores Monitorados até o mês de junho de 2013 Projeto Guandu

\begin{tabular}{l|r}
\hline \multicolumn{1}{c|}{ Indicadores } & \multicolumn{1}{c}{ Total } \\
\hline Número de proprietários contratados & 62 \\
\hline Hectares conservados & $4.157,93 \mathrm{ha}$. \\
\hline Hectares em restauração & $491,1 \mathrm{ha}$. \\
\hline $\begin{array}{l}\text { Pagamentos realizados aos provedores contratados no período de } \\
\text { agosto de 2012 a junho de 2013 }\end{array}$ & $\mathrm{R} \$ 118.399,25$ \\
\hline Pagamentos acumulados realizados aos provedores contratados & $\mathrm{R} \$ 278.632,37$ \\
\hline
\end{tabular}

FONTE: Gestores do projeto

A partir do ano de 2014, vai ser estudado um novo formato ao financiamento do projeto, no qual o Comitê da Bacia Hidrográfica do Guandu assume praticamente todos os custos do projeto, inclusive, o pagamento aos produtores. Esse formato ainda está sob análise.

Na avaliação dos participantes, o ponto forte do projeto é o comprometimento dos parceiros, especialmente a qualificação técnica que permitiu seu avanço. Por outro lado, destacaram-se como pontos fracos e desafios a serem enfrentados o arranjo financeiro formatado do projeto, que passa por avaliação de mudança a partir de 2014, a falta de definição de uma política e a regulamentação de PSA, ou seja, a fragilidade da base legal dos projetos de pagamento por 
serviços ambientais.

Por fim, o gestor destacou que não há um levantamento de avaliação formal por parte dos produtores, mas percebe-se, nas reuniões e nos encontros periódicos realizados, que não há descontentamento por parte dos produtores contratados. Essa é uma informação de grande relevância no contexto das relações de contratuais de prestação de serviços ambientais, principalmente, por ficar caracterizada a conscientização dos produtores rurais em contribuir e aceitar as regras institucionais ambientais.

\subsubsection{Projeto Produtor de Água na Bacia Hidrográfica Piracicaba/Capivari/Jundiaí PCJ}

O projeto Produtor de Água na Bacia Hidrográfica dos Rios Piracicaba, Capivari e Jundiaí é um projeto piloto de PSA no estado de São Paulo, em que as estratégias desenhadas são testadas e avaliadas, constituindo um importante subsídio para os programas de maior escala. Os rios compõem as microbacias hidrográficas dos mananciais da sub-bacia do Cantareira.

O projeto tem como foco a manutenção da regularidade de fluxo e qualidade da água em microbacias hidrográficas do Sistema Cantareira, e seus objetivos são:

a) reduzir a poluição difusa rural, por meio do incentivo à adoção de práticas eficazes e sustentáveis;

b) prover água de melhor qualidade para usuários situados a jusante de áreas rurais (mananciais);

c) conscientizar os produtores e os consumidores de água sobre a importância do manejo integrado de bacias hidrográficas;

d) buscar mecanismos de compensação para os produtores participantes.

Destaca o gestor que o projeto tem como finalidade avaliar um instrumento econômico - o PSA - como dispositivo estimulante à adoção de boas práticas, priorizando os serviços ambientais relacionados aos recursos hídricos, sem, contudo, deixar de observar os impactos positivos em outros tipos de serviços, tais como a conservação, a recuperação da diversidade biológica e a fixação do carbono atmosférico. 
As microbacias escolhidas para o desenvolvimento do projeto foram a microbacia do Ribeirão Cancan, no município de Joanópolis, e a microbacia do Ribeirão Moinho, no município de Nazaré Paulista. Essas bacias estavam inseridas no Programa Estadual de Microbacias Hidrográficas e abrangem 4.212 hectares, com uma população de 311 pessoas e 130 propriedades rurais, com exploração de atividades de pecuária e plantio de eucalipto para exploração madeireira (PADOVEZI et al, 2012).

Esse projeto teve a adaptação do modelo de PSA empregado já existente no município de Extrema (MG), que se localiza em área vizinha; a diferença entre os projetos decorre da fórmula do cálculo do pagamento. O projeto mineiro calcula o PSA em um valor fixo por hectare, multiplicado pelo tamanho da propriedade; enquanto neste projeto a definição do PSA pago ao produtor leva em consideração os valores de referência que são multiplicados pelos hectares dedicados a intervenções específicas na propriedade rural (conservação de solo e floresta, e restauração florestal).

O arranjo institucional ${ }^{92}$ para o desenvolvimento do projeto teve a participação das seguintes entidades, cada uma com funções específicas, a saber:

a) Prefeitura Municipal de Extrema: atua no gerenciamento conjunto do projeto;

b) Prefeitura Municipal de Nazaré e de Joanópolis: atuam como apoiadoras do projeto;

c) Secretaria do Meio Ambiente do Estado de São Paulo (SMA): órgão do governo do estado que trabalha por meio do projeto de recuperação de Matas Ciliares (PRMC), atua na atividade de gerenciamento do projeto por meio da Unidade de Gerenciamento do Projeto (UGP); e é responsável pela elaboração do projeto de restauração de florestas em APP.

d) Secretaria da Agricultura e Abastecimento (SAA): órgão do governo que - por meio de sua Coordenadoria de Assistência Técnica Integral (CATI), responsável pela elaboração do projeto de conservação do solo - atua também na atividade de gerenciamento do projeto por meio da Unidade de Gerenciamento do Projeto

\footnotetext{
${ }^{92} \mathrm{O}$ sentido utilizado aqui é aquele entre as unidades econômicas que administram o meio pelo qual tais unidades podem cooperar (...) ou podem fornecer um mecanismo que pode proporcionar uma mudança nas leis ou no direito de propriedade (WILLIAMSON, 1996).
} 
(UGP);

e) The Nature Conservancy (TNC): entidade da sociedade civil que atua como responsável pela elaboração do projeto de conservação de fragmentos florestais, responsável pela elaboração dos contratos de PSA e tomadora do recurso dos comitês do PCJ destinado ao PSA; atua também na atividade de gerenciamento do projeto por meio da Unidade de Gerenciamento do Projeto (UGP);

f) Agência Nacional de Águas (ANA): atua no gerenciamento conjunto do projeto;

g) Comitês das Bacias Hidrográficas dos Rios Piracicaba, Capivari e Jundiaí: empresa pública que atua no gerenciamento do conjunto do projeto e repassa os recursos para pagamento dos produtores rurais.

As entidades parceiras do projeto formaram, em 2009, a Unidade de Gestão do Projeto (UGP), um colegiado formado por representantes de cada uma das entidades parceiras. As instituições que compõem a UGP contribuirão com a implantação e a manutenção das atividades do projeto por meio de seus programas/projetos específicos ${ }^{93}$.

Os valores de referência para pagamento das modalidades de restauração e conservação foram definidos com base no custo de oportunidade dos usos alternativos do solo, considerando especialmente as pastagens, principal destinação de uso agrícola do solo na região.

O projeto prevê remuneração aos produtores rurais pela prestação de serviços ambientais em três modalidades distintas:

a) práticas que resultem na restauração em APP, recompensando financeiramente o proprietário rural que recuperar as APPs de sua propriedade;

b) práticas que resultem na conservação de florestas existentes, remunerando os proprietários que conservarem os fragmentos florestais existentes na propriedade, estando estes dentro ou fora das APPs;

c) práticas que resultem na conservação do solo, recompensando financeiramente o proprietário rural que já adota e os que vierem a adotar práticas de conservação de solo em sua área de agricultura e/ou pastagem (PADOVEZI et al, 2012).

\footnotetext{
${ }^{93}$ Instituto de Conservação Ambiental - The Nature Conservancy do Brasil - Edital nº. 01/2009 - Pagamento por Serviços Ambientais a proprietários rurais.
} 
Para o pagamento pela restauração em área de APP, os valores de referência são calculados em função da qualidade da manutenção pós-implantação. São consideradas como "restaurações medianamente cuidadas" aquelas em que há falta de zelo ou baixa qualidade da manutenção das ações implantadas e, consequentemente, prejuízo para o processo de sucessão ecológica. Como "restaurações bem cuidadas", são consideradas aquelas em que há zelo e manutenção adequada para as ações de restauração florestal implantadas, o que, consequentemente, acelera o processo de sucessão ecológica. Para o monitoramento, foi desenvolvido um checklist para avaliar o desenvolvimento das atividades implantadas. $\mathrm{O}$ valor a ser pago por hectare de floresta remanescente cresce com a qualidade das florestas existentes. E o pagamento pela conservação do solo contempla não só práticas de conservação de solo, mas também práticas já adotadas pelos agricultores, variando em função do percentual de abatimento de erosão, que é calculado levando-se em conta as perdas de solo antes e após a adoção das práticas de conservação (PADOVEZI et al, 2012).

Em resumo, os valores definidos para pagamento no projeto estão dispostos na Tabela 3, a seguir.

Tabela 3 - Valores de referência do produtor de água no PCJ (R\$/ha/ano)

\begin{tabular}{c|c|c|c|c|c|c|c|c}
\hline \multicolumn{2}{c|}{ Restauração de APP } & \multicolumn{3}{c|}{ Conservação de Florestas } & \multicolumn{2}{c}{ Conservação do Solo } \\
\hline \multicolumn{2}{c|}{ Avaliação da Restauração } & \multirow{2}{*}{$\begin{array}{c}\text { Estágio } \\
\text { Sucessional } \\
\text { da Floresta }\end{array}$} & \multicolumn{2}{|c|}{ \% de Apps a serem restauradas } & \multicolumn{2}{c}{$\begin{array}{c}\text { Percentual de abatimento de } \\
\text { erosão }\end{array}$} \\
\cline { 1 - 5 } $\begin{array}{c}\text { Medianamente } \\
\text { cuidada } \\
(\mathrm{R} \$)\end{array}$ & $\begin{array}{c}\text { Bem } \\
\text { cuidada } \\
(\mathrm{R} \$)\end{array}$ & $\begin{array}{c}\text { Médio ou } \\
\text { Avançando }\end{array}$ & 42 & 83 & 125 & 25 & 50 & 75 \\
\hline 83 & 125 & Inicial & 25 & 50 & 75 & & & 75 \\
\hline
\end{tabular}

FONTE: PADOVEZI et al, 2012, p. 104.

Poderão participar do projeto todos os proprietários rurais cujas propriedades estejam inseridas total ou parcialmente dentro dos limites das microbacias do Ribeirão Moinho e do Ribeirão Cancan, condicionado à comprovação de sua propriedade ou posse do imóvel. Destacam-se, entre os critérios mínimos para inclusão dos proprietários no projeto, a proteção de no mínimo $15 \%$ da APP conservada, somada à área a restaurar por meio do projeto e a concordância com pelo menos $25 \%$ do proposto pelos técnicos no projeto ideal.

O funcionamento do projeto tem seu início com a busca pelo produtor rural na Casa da Agricultura de seu município, e termina quando o produtor, já participando do projeto, recebe 
pelos serviços ambientais prestados pela sua propriedade, conforme Figura 7, a seguir.

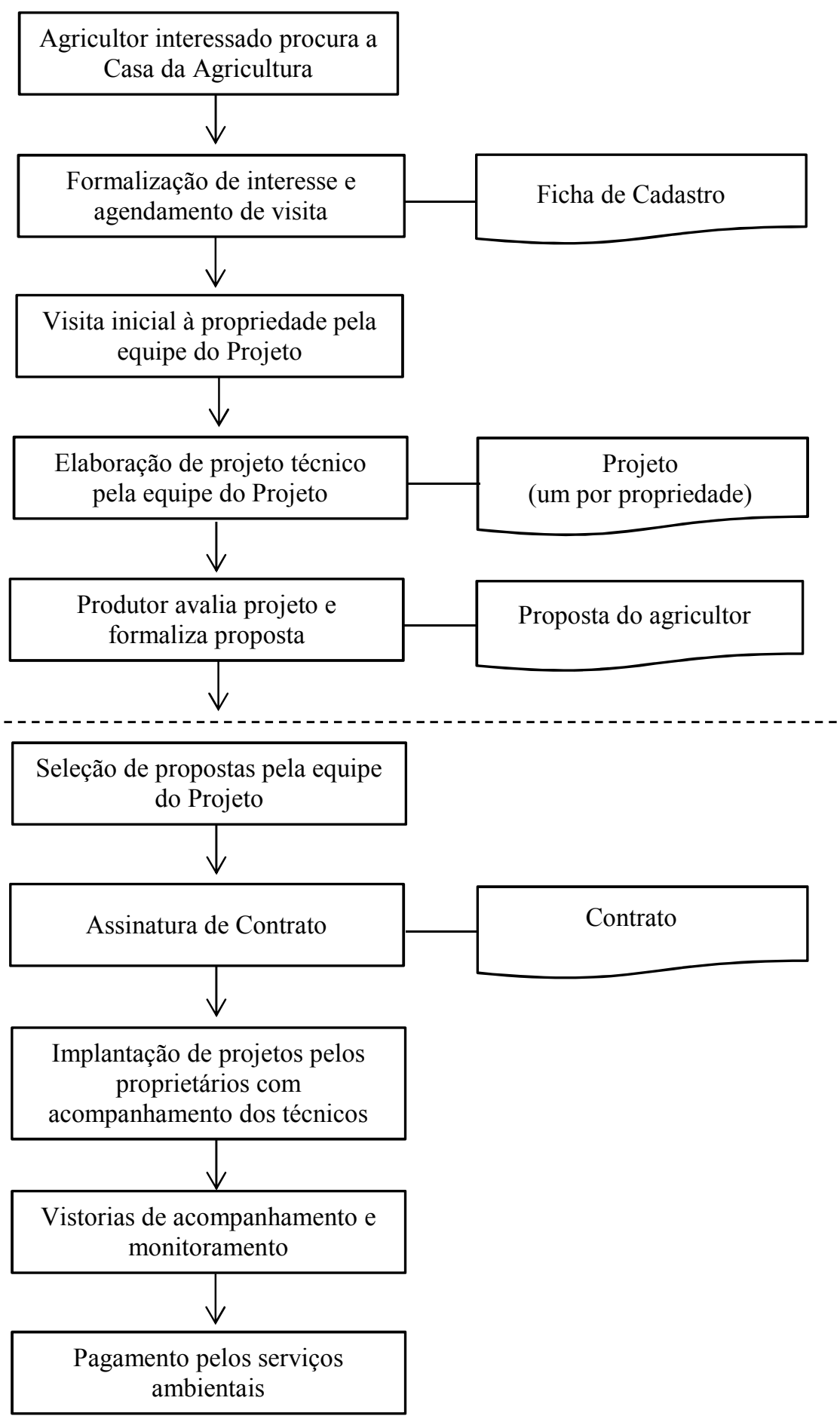


Figura 7 - Funcionamento do Projeto Produtor de Água no PCJ FONTE PADOVEZZI et al (2012, p. 107).

Após a aprovação do projeto e da documentação dos agricultores, ocorre a elaboração do contrato de prestação de serviços entre o produtor e a TNC, que, nesse caso, foi a tomadora do recurso dos Comitês PCJ destinado ao PSA. Esse contrato tem duração de três anos e estabelece as condições e o comprometimento do produtor na execução das atividades acordadas no projeto executivo. Os pagamentos aos produtores ocorrem via depósito em conta corrente, em seis parcelas semestrais, com geração de RPA (recibo de pagamento autônomo). Os tributos devidos, atualmente, são pagos pelo projeto.

Os pagamentos pelos serviços ambientais aos produtores somente ocorrerão após a vistoria realizada pela equipe técnica do Projeto e por representantes da Câmara Técnica Rural dos Comitês PCJ, atestando que as atividades previstas nos planos de trabalho acordados individualmente estão sendo cumpridas e bem executadas. Os recursos utilizados para pagamento do serviço ambiental prestado são oriundos da cobrança pelo uso da água, cujo gerenciamento é feito pelos Comitês PCJ e executados pela Agência de Água PCJ, ou seja, são recursos públicos repassados a produtores considerados propriedades particulares.

Dessa forma, o projeto segue a lógica do usuário-pagador, provedor-recebedor, com os proprietários, provedores ou mantenedores do serviço ambiental recebendo incentivos por serviços prestados para a sociedade inserida na bacia hidrográfica do PCJ.

O projeto PCJ teve como fundamentação legal a legislação estadual do estado de São Paulo, por meio da Lei ${ }^{\text {o }} 13.798^{94}$, (SÃO PAULO, de 2009), na seção XVI - Dos Instrumentos Econômicos em seu art. 23, in verbis,

\footnotetext{
SEÇÃO XVI

Dos Instrumentos Econômicos

Artigo 23 - O Poder Executivo instituirá, mediante decreto, o Programa de Remanescentes Florestais, sob coordenação da Secretaria do Meio Ambiente, com o objetivo de fomentar a delimitação, demarcação e recuperação de matas ciliares e outros tipos de fragmentos florestais, podendo prever, para consecução de suas finalidades, o pagamento por serviços ambientais aos proprietários rurais conservacionistas, bem como incentivos econômicos a políticas voluntárias de redução de desmatamento e proteção ambiental.
}

\footnotetext{
${ }^{94}$ A regulamentação da Lei $n^{\circ}$ 13.798, (SÃO PAULO, 2009), foi instituída pelo Decreto ${ }^{\circ}$ 55.947, (SÃO PAULO, 2010).
} 
Segundo o gestor, dois foram os grandes desafios do projeto. Primeiro, a manutenção da articulação institucional a partir da formação da UGP; e, segundo, a conquista da confiança do produtor rural, provando que a iniciativa do PSA vem ao encontro de suas necessidades. Nesse sentido, destaca-se que a baixa adesão dos produtores ao projeto - até 2012, quando foi realizada a entrevista, eram 17 contratos assinados e 29 aprovados pela UGP em fase de elaboração de contratos - pode estar relacionada aos seguintes motivos:

a) a falta ou a dificuldade para a aquisição de documentos pessoais ou que comprovem a posse ou propriedade do imóvel;

b) a desconfiança dos agricultores quanto à real efetivação do projeto, uma vez que vários projetos já lhes foram apresentados por instituições diversas, sem, no entanto, se concretizarem;

c) o baixo valor do PSA, já que, em vários casos, os produtores apresentam outras atividades mais rentáveis na propriedade ou são proprietários rurais residentes nas cidades, com fontes de renda mais rentáveis, não condizentes com a realidade rural da região;

d) a desconfiança em relação à formalidade existente para a efetivação do pagamento, visto que é necessária a elaboração de um contrato de prestação de serviços - embora esse seja um aspecto positivo para o agricultor, o mesmo frequentemente enxerga essa formalidade como uma etapa negativa no processo;

e) o receio de perder terras agrícolas por atividades de restauração florestal em APP; e,

f) a incerteza quanto a situação do Código Florestal Brasileiro (PADOVEZI et al, 2012, p. 107).

A partir disso, os parceiros do projeto vêm discutindo alternativas para maior participação e adesão dos produtores ao projeto, destacando-se a elaboração de um plano de ação em cada microbacia, com produtores em potencial para envolvimento no projeto; a simplificação da documentação necessária à adesão ao projeto; a solicitação da documentação necessária ao projeto já no primeiro contato com o produtor; a redistribuição e a difusão de material de comunicação informativo do projeto.

\subsubsection{Projeto ProdutorES de Água}

O projeto ProdutorES de água ${ }^{95}$ é um mecanismo de PSA do Estado do Espírito Santo, cujo serviço ambiental objetiva a melhoria da qualidade de água mediante o abatimento dos processos erosivos nas bacias hidrográficas do Rio Benevente, São José e Guandu.

Destacam-se como objetivos do projeto a criação de mecanismos capazes de fazer retornar aos proprietários de áreas rurais, sensíveis sob o ponto de vista hidrológico, parte dos custos

\footnotetext{
${ }^{95}$ A identificação do projeto é igual ao nome do Programa Produtor de Água da Agência Nacional de Águas (ANA) acrescido da sigla ES, que identifica o Estado do Espírito Santo.
} 
nos quais incorrem esses proprietários ao atuar como facilitadores para a prestação dos serviços de melhoria da qualidade da água.

A definição das bacias prioritárias foi em virtude da possibilidade de formação de um mercado por serviços ambientais, no qual se encontram pequenos e médios proprietários rurais que mantêm as florestas em pé nas cabeceiras, e o Polo Industrial e de Serviços de Anchieta (PISA) no baixo curso (foz do Rio Benevente) em franco crescimento. O município contemplado nessa bacia é Alfredo Chaves, pelo fato de as cabeceiras estarem 100\% inseridas nele. O uso do solo nas cabeceiras é principalmente ocupado pela agricultura do café e da banana, e a silvicultura do eucalipto vem ganhando destaque nos últimos anos. Ressalte-se que $80 \%$ das propriedades capixabas são consideradas pequenas, de até 50 hectares (INCRA, 2002).

A expansão do Projeto ocorreu nas bacias hidrográficas do rio Guandu e do rio São José. Para tanto, novamente foram definidas as áreas de cabeceiras, como prioritárias para a implementação do mecanismo de PSA, nos municípios de Brejetuba e Afonso Cláudio, no rio Guandu, e Mantenópolis e Alto Rio Novo, no rio São José.

$\mathrm{O}$ ambiente institucional para implantação do projeto foi a aprovação da Lei Estadual $\mathrm{n}^{\circ}$ 8.995, (ESPIRITO SANTO, 2008), que instituiu o Programa de Pagamento por Serviços Ambientais (PSA), que foi regulamentado pelo Decreto $n^{\circ}$. 2.168 R (ESPÍRITO SANTO, 2008). Essa lei foi revogada pela Lei nº 9.864 (ESPÍRITO SANTO, 2012). Essa legislação é direcionada ao proprietário de área rural, no estado do Espírito Santo, que destinar parte de sua propriedade para fins de preservação e conservação da cobertura florestal e incremento da qualidade e da disponibilidade hídrica.

Segundo a legislação, que instituiu o programa de pagamento por serviços ambientais no estado do Espírito Santo, os serviços ambientais que recompensam financeiramente o proprietário rural são:

a) conservação e melhoria da qualidade e da disponibilidade hídrica;

b) conservação e incremento da biodiversidade;

c) redução dos processos erosivos;

d) fixação e sequestro de carbono para fins de minimização dos efeitos das 
mudanças climáticas globais ${ }^{96}$.

Essa compensação financeira será em função do valor econômico dos serviços ambientais prestados. Para propor esses mecanismos, utiliza-se o conceito de provedor-recebedor.

O arranjo institucional ${ }^{97}$ para a implantação do projeto foi formado pelas instituições, e cada uma tem atribuições específicas em seu desenvolvimento e implantação:

a) Governos federal, estadual e municipal: atuam como apoiadores do projeto;

b) Instituto Estadual de Meio ambiente e Recursos Hídricos (IEMA): órgão do governo do estado, atua nas seguintes atividades: coordenação e gestão do projeto, avaliação das inscrições do projeto e suporte técnico; monitoramento técnico dos contratos; articulação com demais atores; definição de áreas prioritárias e seu mapeamento; elaboração das metodologias; e elaboração da legislação de PSA;

c) Fundo Estadual de Recursos Hídricos (FUNDAGUA): fundo vinculado à Secretaria de Estado de Meio Ambiente e Recursos Hídricos (SEAMA), tem o Instituto Estadual do Meio Ambiente (IEMA) na função de secretaria executiva, e atua na elaboração dos projetos de PSA e no monitoramento administrativo dos contratos de PSA;

d) Banco de Desenvolvimento do Estado do Espírito Santo (BANDES): empresa pública que participa como gestor financeiro do FUNDAGUA, é responsável pelo depósito do PSA na conta dos produtores rurais;

e) Instituto Capixaba de Pesquisa, Assistência Técnica e Extensão Rural (INCAPER): órgão do governo do Estado do Espírito Santo, atua na mobilização e articulação no campo integração com as políticas territoriais da SEAG;

f) Instituto de Defesa Agropecuária e Florestal do Espírito Santo (IDAF): órgão do governo do Estado do Espírito Santo que atua na disponibilização de mapeamentos realizados para reserva legal, secretarias de Agricultura e Meio Ambiente dos municípios, e na articulação e mobilização nas comunidades rurais;

g) Instituto Bio Atlântica (IBIO): entidade da sociedade civil que atua nas atividades de avaliação da inscrição do projeto, no suporte técnico, no monitoramento

\footnotetext{
${ }^{96}$ Art. $2^{\circ}$ da Lei no 8.995 (ESPÍRITO SANTOS, 2008).

${ }^{97} \mathrm{O}$ sentido utilizado aqui é aquele entre as unidades econômicas que administram o meio pelo qual tais unidades podem cooperar (...) ou podem fornecer um mecanismo que pode proporcionar uma mudança nas leis ou no direito de propriedade (WILLIAMSON, 1996)
} 
técnico dos contratos de PSA, na articulação com os demais atores, na definição das áreas prioritárias e seus mapeamentos, na elaboração das metodologias e da legislação de PSA;

h) The Nature Conservancy (TNC): entidade da sociedade civil que atua nas atividades de capacitação dos atores locais, no apoio dos mapeamentos, no monitoramento da cobertura vegetal e na articulação para monitoramento da qualidade da água;

i) Instituto Terra: entidade da sociedade civil que atua no mapeamento das propriedades;

j) Consórcio Intermunicipal do Rio Guandu: atua na articulação com os atores da bacia do Guandu, na mobilização nas comunidades rurais e na integração entre ações que ocorrem na bacia e o projeto;

k) Agência Nacional de Águas (ANA): atua nas atividades de apoio à elaboração de metodologias e na divulgação do projeto;

1) Comitês de Bacias dos rios: empresa pública que atua na articulação com atores das bacias.

Percebe-se que tanto os setores públicos quanto a sociedade civil desempenham papel importante para o desenvolvimento do projeto nas bacias contempladas pelo PSA no Espírito Santo.

O projeto identificou os usuários beneficiados ${ }^{98}$ pelos serviços ambientais prestados destacando as concessionárias de hidroenergia e as empresas de tratamento e distribuição de água potável, sendo essas diretamente beneficiadas pelas intervenções positivas realizadas pelos produtores. Além disso, o setor privado e a própria sociedade consumidora, os usuários dessas águas, poderão configurar-se como beneficiários desses serviços ambientais prestados pelos remanescentes de Mata Atlântica, que se encontram, em sua expressiva maioria, nas mãos de pequenos e médios proprietários rurais, como afirma o próprio gestor.

O valor a ser pago de PSA ao proprietário rural é fixado em reais por hectare, levando em consideração a fórmula indicada no Quadro 9. O objetivo dessa fórmula é ponderar, por meio

\footnotetext{
${ }^{98}$ Comitê de Bacias Hidrográficas, Companhia Espírito-Santense de Saneamento (Cesan), Serviços Autônomos de Água e Esgoto (SAA- Es Municipais), Polo Industrial e de Serviços de Anchieta (PISA), Polo Empresarial do Baixo Guandu, São Joaquim Energia S.A (PCH São Joaquim) (AHNERT et al, 2012, p. 276).
} 
de parâmetros técnicos e orçamentários, cada situação passível de ser contemplada pelo projeto.

Quadro 9 - Fórmula de cálculo do PSA Projeto ProdutorES de Água

que,

\section{VSrh $=200$ VRTE $\times(1-Z) \times K t$}

> VSrh é o valor dos serviços ambientais de conservação e incremento da qualidade $\square$ e da disponibilidade hídrica em $\mathrm{R} \$ /$ ha ano;

$>200$ VRTE é o custo de oportunidade para o serviço ambiental, acrescido de adequações orçamentárias;

$>$ Z é o coeficiente de potencial erosivo referente ao estágio de desenvolvimento da floresta;

$>$ Kt é o coeficiente de ajuste topográfico.

FONTE: AHNERT et al, 2012

Para o cálculo do custo de oportunidade para o estado do Espírito Santo, levaram-se em consideração as atividades de pecuária, café, eucalipto, cana-de-açúcar e banana indicadas como representativas, pelo fato de, juntas, corresponderem por, aproximadamente, $91,76 \%$ da área produtiva do estado. Para identificação dos valores de rentabilidade por hectare por ano, foram adotadas informações cedidas pelo INCAPER e pelo Centro de Desenvolvimento do Agronegócio (CEDAGRO). Para efeito de estimativa de áreas de produção, foram adotados os dados do INCAPER e do Instituto Brasileiro de Geografia e Estatística (IBGE). Para a atividade pecuária, o valor do hectare foi ponderado em $\mathrm{R} \$ 217,00$; para a atividade de café, o valor foi de $\mathrm{R} \$ 379,00$; para a atividade de eucalipto, $\mathrm{R} \$ 68,00$; para a atividade de cana-deaçúcar, R \$ 11,00; e, para a atividade de exploração de banana, o valor foi de R \$ 3,00. A partir do estabelecimento do valor ponderado, calculou-se a média de $\mathrm{R} \$ 679,00$, que corresponde a $92 \%$, considerado área produtiva, o que, por regra simples, implicou $\mathrm{R} \$ 740,00$. O valor médio pago por hectare por ano foi estipulado em $\mathrm{R} \$ 148,62$, o que equivale a $\mathrm{R} \$ 1.514,62$, por propriedade (AHNERT, 2012).

Os dados da evolução financeira e de áreas preservadas do Projeto ProdutorEs de Água estão demonstrados na Tabela 4.

Tabela 4 - Demonstrativo da evolução da área sob contrato de PSA ProdutorEs de Água

\begin{tabular}{c|c|c|r}
\hline Ano & $\mathbf{N}^{\mathbf{0}}$ de Contratos & Área (hectares) & Valor PSA Pago (R\$) \\
\hline 2009 & 27 & 399,06 & $158.766,70$ \\
\hline 2010 & 153 & $1.496,24$ & $671.373,28$ \\
\hline 2011 & 37 & 316,15 & $155.876,05$ \\
\hline TOTAL & $\mathbf{2 1 7}$ & $\mathbf{2 . 2 1 1 , 4 5}$ & $\mathbf{9 8 6 . 0 1 6 , 0 3}$ \\
\hline
\end{tabular}

FONTE: MEIO AMBIENTE ES e AHNERT 
Disponível em:

$<$ http://www.meioambiente.es.gov.br/download/PRODUTORES_CONTRATOS_2009_2010.PDF $>$. Acesso em: 20 jul. 2014.

Disponível em:

<http://www.sigam.ambiente.sp.gov.br/sigam2/Repositorio/222/Documentos/2011_Seminario\%20PSA/Fabio\%2 0Ahnert.pdf>. Acesso em: 20 jul. 2014.

Essa evolução está representada no Gráfico 2, que demonstra a evolução acumulada das áreas sob contrato e dos valores pagos em relação à adesão de novos contratos. No total de 217 contratos (demonstrados em valores absolutos), o total das áreas cobertas por esses contratos é de 2.211,45 hectares (demonstrados acumulados). O valor do pagamento total de $\mathrm{R} \$$ 986.016,03, para efeito de representação gráfica, está demonstrado acumulado à razão de 1000 em escala.

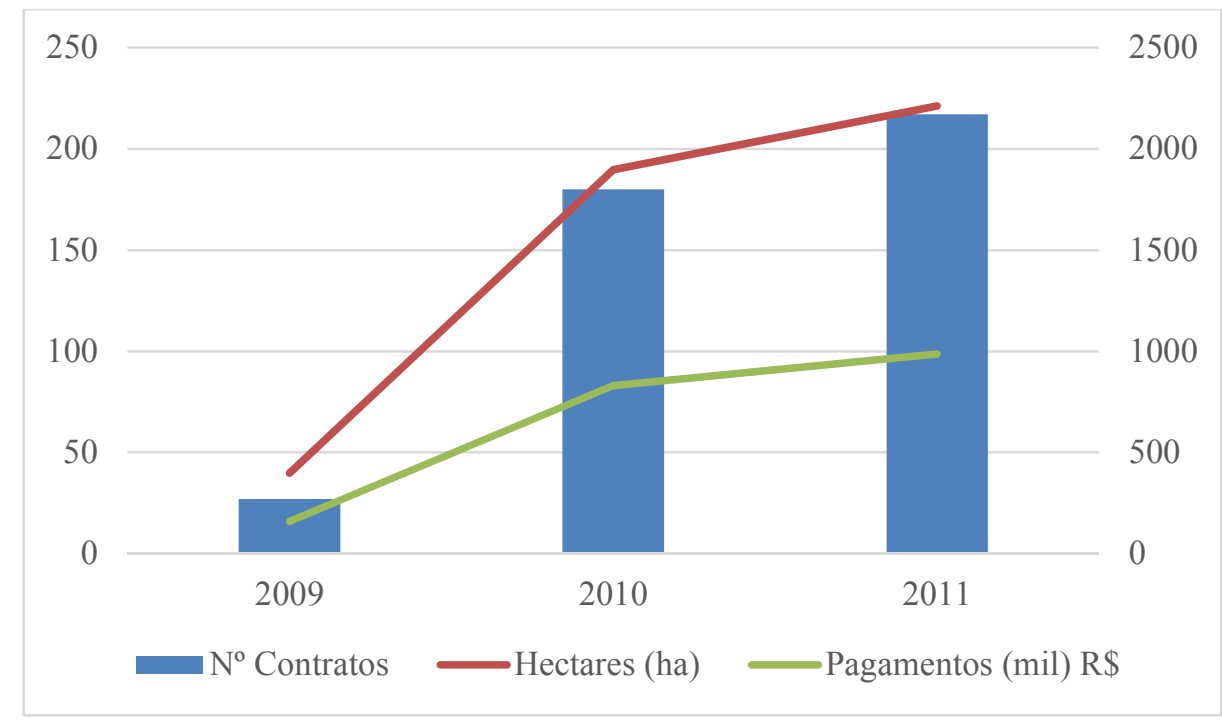

Gráfico 2 - Evolução do Projeto ProdutorES de Águas

Os recursos para o financiamento do PSA do projeto foram obtidos a partir dos recursos do FUNDÁGUA, que é um fundo financeiro público cujo objetivo principal é fornecer suporte à gestão de recursos hídricos no estado do Espírito Santo e instituído por meio da Lei Estadual $\mathrm{n}^{\circ} 8.960$ (ESPIRITO SANTOS, 2008), regulamentada pelo Decreto Estadual $\mathrm{n}^{\circ}$ 2167-R (ESPIRITO SANTOS, 2008).

Constituem recursos do FUNDÁGUA, definido pela Lei no . 8.960, (ESPÍRITO SANTO, 2008), as seguintes fontes:

I - parcela do produto da arrecadação proveniente da compensação financeira dos "royalties" do petróleo e do gás natural, contabilizados pelo Estado do Espírito Santo, sendo: a) 1\% (um por cento) no exercício financeiro de 2008; b) 2\% (dois por cento) no exercício financeiro de 2009; e 
c) 3\% (três por cento) no exercício financeiro de 2010 em diante;

II - o resultado de aplicações de multas cobradas dos infratores da legislação de uso dos recursos hídricos;

III - cota-parte integral da compensação financeira de recursos hídricos recebidos pelo Estado do Espírito Santo;

IV - recursos consignados nos orçamentos públicos municipal, estadual e federal, por disposição legal ou orçamentária;

V - doações e transferências, financeiras ou não, de pessoas físicas ou jurídicas, públicas ou privadas;

VI - empréstimos e outras contribuições financeiras de entidades nacionais e internacionais;

VII - recursos de transferências negociadas e não onerosas, junto a organismos nacionais e internacionais de apoio e fomento;

VIII - recursos oriundos da amortização, correção, juros e multas dos financiamentos efetuados pelo próprio Fundo;

IX - recursos patrimoniais;

$\mathrm{X}$ - quaisquer outras receitas vinculadas ao FUNDÁGUA.

A legislação também determinou que os recursos do FUNDÁGUA deverão ser aplicados: $40 \%$ do seu montante são utilizados para implementar programas e projetos voltados à recuperação de nascentes, fortalecimento dos Comitês de Bacia entre outros, e $60 \%{ }^{99}$ dos seus recursos são destinados à implementação do Programa de PSA, por meio do Projeto.

O projeto prevê o início, quando da convocação dos proprietários da região onde a bacia foi contemplada com o projeto, por meio do lançamento de portaria, que determina as regras de participação no Projeto ProdutorEs de Água. Para participar, o proprietário deve apresentar os seguintes documentos:
a) requerimento de participação no projeto: em que informações da propriedade são solicitadas;
b) documento de identidade e CPF: o projeto só remunera proprietários rurais que são pessoas físicas e não jurídicas;
c) documento comprobatório da posse da propriedade: escritura, certidão de cadastro de imóvel rural, contrato de arrendamento, entre outros;
d) comprovante de residência com no máximo dois meses de vencimento (AHNERT et al, 2012).

Após a formalização da documentação, a execução do projeto passa pelas seguintes etapas:

a) mapeamento da propriedade: que ocorre de forma participativa do proprietário, definindo os limites de sua propriedade e dos fragmentos florestais que são passíveis de PSA;

b) cálculo do PSA e repasse do mapeamento;

c) elaboração do contrato de PSA;

d) assinatura dos contratos e repasse do PSA ao proprietário;

\footnotetext{
${ }^{99}$ Lei 8.960 , (BRASIL, 2008), art. $7^{\circ}$, Parágrafo $1^{\circ}$.
} 
e) monitoramento e revistoria da propriedade.

Ressalte-se que, para o repasse da segunda e terceira parcelas do PSA, faz-se necessário revistoria na propriedade e monitoramento da cobertura florestal que estão mapeadas para PSA e aquelas que porventura o proprietário tenha recuperado (AHNERT et al, 2012).

O contrato de PSA tem duração de três anos, podendo ser renovado por mais duas vezes. Ele rege as responsabilidades do Comprador do Serviço Ambiental, no caso, o Estado do Espírito Santo, e dos Prestadores do Serviço, no caso, o proprietário rural. Os repasses são feitos anualmente, durante três anos. Finalmente, o gestor destaca como pontos positivos a integração entre programas e projetos governamentais e não governamentais, e identifica a satisfação dos proprietários rurais que aderiam ao projeto. Destaca, ainda, que a falta de informação e dados sobre os custos das operações de comercialização é um gargalo do projeto.

\subsubsection{Projeto Produtores de Água do Rio Camboriú}

O projeto Produtores de Água do Rio Camboriú, criado por meio da Lei Municipal $n^{\circ}$. $3.026^{100}$, (BALNEÁRIO CAMBORIU, 2009), da Prefeitura Municipal de Balneário Camboriú, foi uma iniciativa da Empresa Municipal de Água e Saneamento (EMASA) do Balneário Camboriú, que se articulou com outras instituições para criar um arranjo capaz de executar o projeto integrado. Essa iniciativa, segundo o gestor, justificou-se, pois o abastecimento de água depende de uma bacia hidrográfica em disponibilidade hídrica no limite, verificando-se, assim, a importância de preservar as áreas de nascente a fim de proteger áreas sensíveis à produção de água. Além disso, o alto grau de assoreamento do manancial comprova a importância da recuperação florestal. Por outro lado, considerando a ineficiência de outros instrumentos de comando e controle e outros projetos sem nenhum incentivo, verificou-se no PSA uma forma de estimular a preservação no âmbito da bacia. Esse projeto foi inspirado no modelo adotado na cidade de Nova York e no Produtor de Água, proposta pela Agência Nacional de Águas.

\footnotetext{
${ }^{100}$ Cria o Projeto Produtor de Água, autoriza a empresa Municipal de Água e Saneamento (EMASA) a pestar apoio financeiro aos proprietários rurais e dá outras providências.
} 
A EMASA foi criada pela Lei $n^{\circ}$. 2.498, (BALNEARIO CAMBORIÚ, 2005), com a obrigatoriedade de destinar pelo menos $1 \%$ de sua arrecadação bruta anual a programas de preservação e recuperação ambiental. A partir de 2008, foi decidido que esse recurso seria destinado ao projeto produtor de águas do Rio Camboriú.

Esse percentual estipulado de $1 \%$ corresponde à dotação orçamentária de recuperação ambiental de orçamento público da EMASA e é a fonte de financiamento para o pagamento dos serviços ambientais.

A Lei no 3.026, (BALNEÁRIO CAMBORIÚ, 2009), teve sua regulamentação por meio do Decreto 6.121, (BALNEÁRIO CAMBORIÚ, 2011), que na nova economia institucional identifica-se como o ambiente institucional.

O objetivo da criação do projeto é a criação de instrumentos, estratégias e metodologias que visem à melhoria da qualidade e da quantidade das águas na bacia hidrográfica do Rio Camboriú. Esse objetivo está confirmado no art. $1^{\circ}$ da Lei $n^{\circ}$. 3.026, (BALNEÁRIO CAMBORIÚ, 2009).

A bacia hidrográfica do Rio Camboriú, segundo os gestores do projeto, tem uma área de aproximadamente 200 quilômetros quadrados e está localizada no estado de Santa Catarina, representando em pequena escala a condição da Mata Atlântica no Brasil. Os municípios que compartilham essa bacia hidrográfica são: Balneário Camboriư ${ }^{101}$ e Cidade de Camboriú ${ }^{102}$. O uso das águas da Bacia do Rio Camboriú, segundo os gestores do projeto, inclui o abastecimento público e a rizicultura.

As propriedades rurais dispostas na bacia hidrográfica do Rio Camboriú têm em média 30,7 hectares, com predominância da atividade pecuária com baixa tecnologia, e reduzidos investimentos em rebanhos e pastagens. Já a atividade agrícola, produção de arroz, é desenvolvida com maior aporte tecnológico.

\footnotetext{
${ }^{101}$ Município litorâneo, altamente urbanizado, com desenvolvimento turístico e aquecido mercado imobiliário, população 108.089 habitantes. (IBGE). Disponível em:

$<$ http://www.cidades.ibge.gov.br/painel/painel.php?lang=\&codmun=420200\&search=|balneario-camboriu $>$. Acesso em: 20 abr. 2014.

${ }^{102}$ Município caracterizado por ambiente rural, com predominância de produção de arroz irrigado em terras baixas e pecuária de baixa tecnologia nas terras secas, população 62.361 habitantes. (IBGE). Disponível em: $<$ http://www.cidades.ibge.gov.br/painel/painel.php?lang=\&codmun=420200\&search=|balneario-camboriu $>$. Acesso em: 20 abr. 2014.
} 
O arranjo institucional ${ }^{103}$ para o desenvolvimento do projeto é formado pelas seguintes instituições, cada uma delas com funções e atribuições específicas:

a) Prefeitura Municipal de Balneário Camboriú e de Camboriú: presta apoio técnico ao projeto;

b) Empresa Municipal de Água e Saneamento (EMASA) do Balneário Camboriú: empresa pública que presta o auxílio financeiro aos proprietários;

c) Agência Reguladora de Serviços de Saneamento Básico de Estado de Santa Catarina (AGESAN): empresa pública que acompanha as ações do projeto;

d) Agência Nacional de Águas (ANA): presta apoio técnico no tema de conservação de solos e manutenção de estradas;

e) Comitê da Bacia hidrográfica do Rio Camboriú: empresa pública que presta apoio técnico ao projeto;

f) Empresa de Pesquisa Agropecuária e Extensão Rural de Santa Catarina (EPAGRI): empresa pública que atua no desenvolvimento de estudos técnicos com foco na previsão de serviços ambientais e realiza o monitoramento hidrometeorológico da bacia hidrográfica;

g) The Nature Consevancy (TNC): entidade da sociedade civil que atua na implantação das atividades de restauração e conservação nas propriedades rurais.

As instituições que participam ativamente do projeto, em 2009, constituíram o Comitê Gestor do Projeto ${ }^{104}$, que a partir de então vem conduzindo as ações do projeto de forma participativa e transparente, afirma o gestor. Neste acordo há registro da intenção e de esforços de todas as instituições em prol do projeto.

O projeto conta também com duas ferramentas tecnológicas que fornecem base para a tomada de decisões. Uma delas é a análise de Área Ativa de Rio, que foi desenvolvida pela TNC, e considera a manutenção da conectividade hidrológica e a variabilidade natural das áreas ripáricas desde as nascentes até a foz; a outra é a Nature Capital Project ${ }^{105}$, que permite a avaliação da importância do capital natural como forma de apoio à tomada de decisão (KLEMZ et al, 2012).

\footnotetext{
${ }^{103} \mathrm{O}$ sentido utilizado aqui é aquele entre as unidades econômicas que administram o meio pelo qual tais unidades podem cooperar (...) ou podem fornecer um mecanismo que pode proporcionar uma mudança nas leis ou no direito de propriedade (WILLIAMSON, 1996)

${ }^{104}$ Art. $7^{\circ}$ da Lei no ${ }^{\circ} .3 .026$ (BALNEÁRIO CAMBORIÚ, 2009).

${ }^{105}$ Formada pela cooperação entre a Universidade de Stanford, a Universidade de Minnesota, a TNC e o Fundo Mundial para a Natureza (WWF).
} 
Para a formação e a construção do projeto, foi realizado o levantamento socioeconômico baseado no cadastramento de propriedades focando as cabeceiras do Rio Braço e Ribeirão dos Macacos, tendo sido cadastradas 298 propriedades rurais inicialmente. Esse levantamento permitiu a definição dos valores de pagamento pela prestação dos serviços ambientais. Essa atividade foi realizada até o final do ano de 2010.

A implantação do projeto ocorreu em três fases e convocou os proprietários interessados por meio de editais de convocação ${ }^{106}$ nos quais foram apresentadas as áreas foco do respectivo edital, as ações de conservação e restauração propostas para atingir os objetivos do projeto, bem como as condições e as regras para adesão e a proposta de valoração dos serviços ambientais. A adesão dos proprietários foi voluntária e ocorreu a partir da resposta dos mesmos aos editais de convocação. Somente puderam participar aqueles que comprovaram a posse do imóvel.

Os critérios de valoração dos serviços ambientais foram definidos a partir do custo de oportunidade da atividade mais expressiva, com base nas propriedades mapeadas e cadastradas existentes e associados à valoração (de disposição a pagar a disposição a receber). Como base nos cálculos a partir de tabelas referenciais da atividade expressiva e na exclusão de alguns custos (não contabilizados pelos produtores) foi calculada a receita média anual por hectare e transformados esses valores em unidades fiscais municipais, para que fosse possível haver reajuste anual dos contratos.

No primeiro edital, foi atribuído como valor para o pagamento pelos serviços ambientais os identificados no Quadro 10, a seguir.

Quadro 10 - Valores de pagamento por serviço ambiental convencionados

\begin{tabular}{|l|c|}
\hline \multicolumn{1}{|c|}{ Ação de proteção/restauração } & Valor (UFM/hectare) \\
\hline Proteção de matas ciliares e nascentes conservadas & 1,5 \\
\hline Restauração de matas ciliares e nascentes degradadas & 1,5 \\
\hline Restauração de áreas degradadas fora de matas ciliares ou nascentes & 1,5 \\
\hline Bônus de áreas com cobertura vegetal nativa & 0,5 \\
\hline Proteção de áreas com cobertura vegetal nativa & 0,5 \\
\hline
\end{tabular}

FONTE: KLEMZ et al, 2012.

\footnotetext{
${ }^{106}$ O primeiro edital, em julho de 2012, foi para as microbacias dos rios Lageado e Limeira, englobando as cabeceiras do rio do Braço.
} 
A lei define como apoio financeiro concedido aos proprietários rurais a remuneração pelos serviços prestados, e a fixação de seu valor tem previsão no art. $6^{\circ}$ da Lei $\mathrm{n}^{\mathrm{o}} 3.026$ (BALNEÁRIO CAMBORIÚ), de 2009. O valor de referência (VR) será de até 15 UFMs ${ }^{107}$ do Município de Balneário Camboriú por hectare, por ano de área recuperada, e prevê, ainda, que as áreas de nascentes terão valor diferenciado, a ser definido pelo grupo gestor, limitado ao máximo de 23 UFMs.

A evolução financeira do projeto está demonstrada na Tabela 5.

Tabela 5 - Evolução Projeto Produtores de Agua Rio Camboriú

\begin{tabular}{l|c}
\multicolumn{1}{c}{ Dados projetos } & Referências \\
\hline Número de contratos vigentes & 8 \\
\hline Quantidade de hectares envolvidos nos contratos & 284,30 \\
\hline Propriedades contratadas & 4 \\
\hline Valor total de contrato de PSA & $\mathrm{R} \$ 111.966,40$ \\
\hline Pagamentos de PSA até 07/2014 & $\mathrm{R} \$ 37.036,20$ \\
\hline Fonte: Gestores do Projeto &
\end{tabular}

Ainda, segundo o gestor, está em fase de negociação e elaboração de projetos mais duas propriedades.

O gestor ressalta que os insumos necessários para as atividades de restauração serão fornecidos pelo projeto, o que pode ser considerado como um benefício adicional ao proprietário que aderir ao projeto.

Os produtores, após o atendimento do edital, formalizarão o termo de adesão e o contrato ${ }^{108}$, em que se comprometem a observar o Projeto Individual de Propriedade (PIP), voltado ao reestabelecimento, à recuperação, à melhoria, à proteção e à manutenção dos ecossistemas. Nesse projeto, serão descritas todas as características das propriedades rurais por meio de um modelo predeterminado. As propriedades que aderirem ao projeto permanecerão pelo prazo mínimo de quatro anos. Aquele que vier a adquirir propriedade rural com as ações implantadas ficará obrigado a dar continuidade ao projeto pelo tempo mínimo estabelecido em 1 ei ${ }^{109}$.

\footnotetext{
${ }^{107}$ Valor da UFM, em 2014, R\$ 209,56. Disponível em:

$<$ http://www.balneariocamboriu.sc.gov.br/aprefeitura.cfm>. Acesso em: jan. 2014.

108 Os contratos são elaborados pela EMASA.

${ }^{109}$ Parágrafo $^{\circ}$ do Art. $2^{\circ}$ da Lei no ${ }^{\circ} 3.026$ (BALANEÁRIO CAMBORIÚ, de 2009).
} 
A frequência de pagamento pelos serviços ambientais é semestral e ocorrerá após a vistoria na propriedade para averiguação do cumprimento das cláusulas contratuais. Os vistoriadores emitirão um relatório e o produtor receberá seu pagamento. Atualmente quem faz o monitoramento é a entidade da sociedade civil TNC.

A avaliação da aptidão para participação do produtor no atendimento ao projeto será realizada pelo preenchimento dos requisitos formais do regulamento e do edital próprio: que estejam localizados dentro das áreas contempladas no ato de chamamento, e ainda, essas áreas sejam estratégicas, definidas para cada sub-bacia hidrográfica do ato de chamamento, e sejam caracterizadas pela cobertura nativa do ecossistema regional.

Após a implantação das ações propostas, serão realizadas avaliações técnicas periódicas às propriedades pela equipe do projeto, de acordo com o papel de cada instituição. Com a aprovação das ações executadas nas propriedades, em cada avaliação periódica pela equipe do projeto, será então realizado o pagamento de acordo com o contrato estabelecido entre as partes.

As ações de proteção e restauração estabelecidas no contrato serão vistoriadas semestralmente ou a qualquer tempo por equipe técnica definida pelo Comitê Gestor do Projeto. O não cumprimento das condições estabelecidas no contrato decorrentes de omissão do contratado e verificado nas vistorias da equipe técnica implicará advertência ao proprietário e estabelecimento de prazo para adequação. No caso da continuidade do não cumprimento das condições estabelecidas no contrato em nova vistoria da equipe técnica, será rescindido o contrato e imediatamente suspenso o apoio financeiro.

$\mathrm{Na}$ avaliação do gestor, o ponto forte do projeto é o recurso como incentivo à preservação. A voluntariedade possibilita flexibilização na disponibilidade de áreas preservadas para recuperação, sem instrumentos de comando e controle, que são importantes, mas em alguns casos ineficazes. A avaliação do produtor será realizada quando das vistorias, mas até agora nenhum formulário ou instrumento foi aplicado, configurando-se apenas como um campo de observação.

Por fim, no que se refere à identificação dos avanços, ainda não foi possível sua medicação, pois, embora o projeto tenha sido criado em 2009, as fases de planejamento e aprovação da lei 
municipal foram demoradas, e o lançamento oficial foi em março de 2013, portanto as ações em campo são bastante recentes. O grande desafio do projeto, por ser um arranjo participativo, é reconhecer o papel de cada um, garantir o pleno desenvolvimento de todas as instituições, sobretudo o reconhecimento institucional do projeto em cada uma delas e posteriormente equilibrar os resultados individuais de cada instituição e compreender o resultado coletivo gerado.

\subsubsection{Dos resultados e discussões dos projetos de produção de água}

A partir dos dados obtidos por meio do modelo de descrição de cada projeto e após a consolidação dessas informações, serão abordados, neste item, os resultados e as discussões dos projetos de PSA de água sob o ponto de vista da teoria da nova economia institucional, abordando o ambiente institucional, os arranjos institucionais com as funções de cada instituição, a metodologia de remuneração dos serviços ambientais, as fontes de recursos, o monitoramento e a percepção dos atores envolvidos.

Para facilitar essa análise foram consolidados os dados de cada projeto no Quadro 11, no qual não constaram apenas as informações sobre o papel desempenhado por cada instituição no projeto, informação já descrita no texto. 


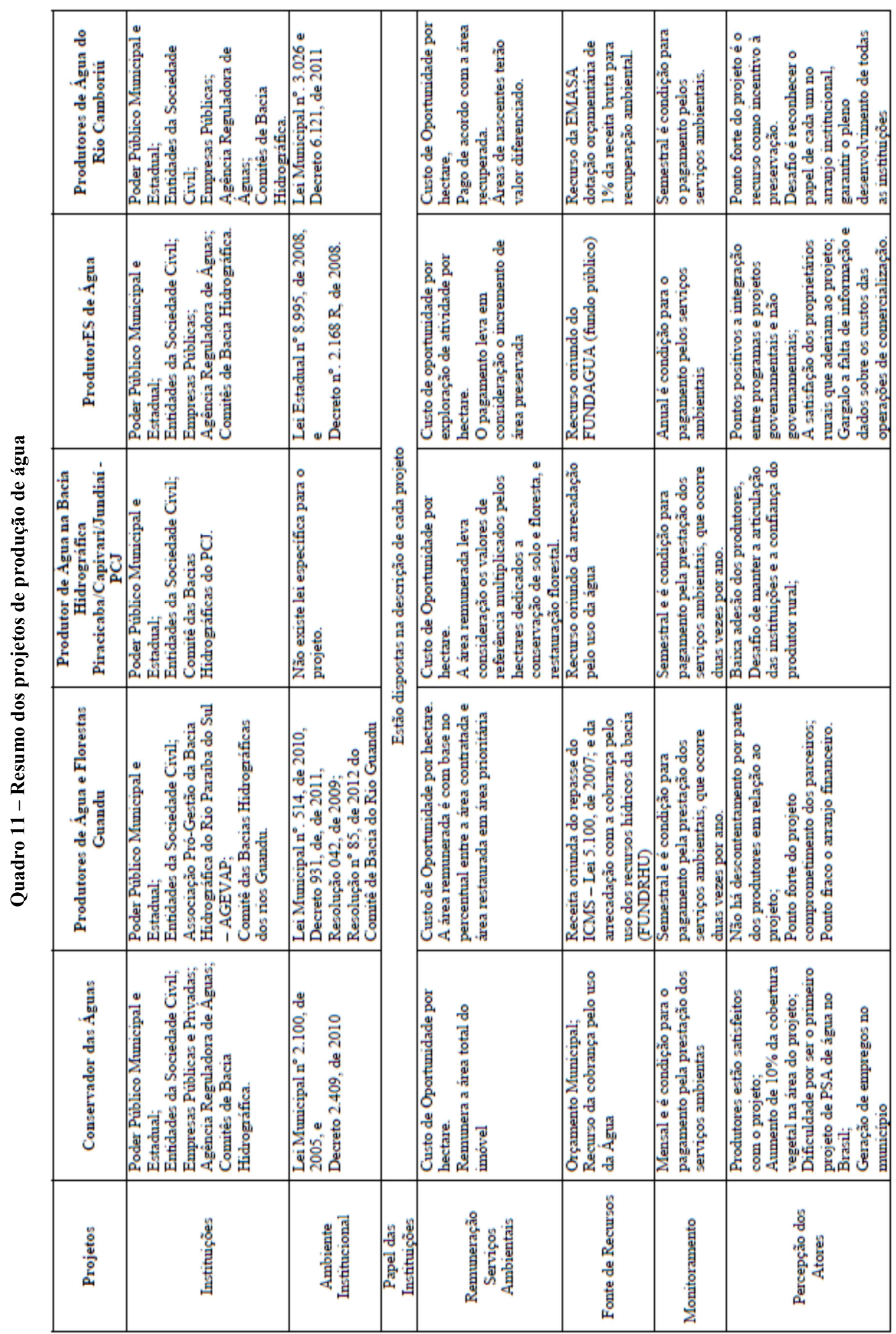


De início convém assinalar que o pagamento por serviços ambientais tem despertado a atenção crescente da sociedade brasileira e assumido importância em todas as discussões em diversas áreas de estudo ambiental contemporâneo. Observa-se nos projetos ora analisados que há uma troca de interesses, com o envolvimento de pessoas físicas ou jurídicas capacitadas para a realização de serviço ambiental de nível qualificado, de modo a oferecer resultados previamente estimados para, consequentemente, o alcance do objetivo maior, que é a sustentabilidade. Por outro lado, existem também as pessoas físicas ou jurídicas com interesses particulares, que estão aptas financeiramente a comprar esses serviços, garantindo a manutenção e o processo de desenvolvimento da sustentável. Como parte integrante dessas relações contratuais, encontram-se os produtores e proprietários rurais, que são levados a aderir aos projetos desenvolvidos por entidades, públicas ou privadas, inicialmente, despertados por motivações financeiras, para executar ações ou tarefas, como a adoção de práticas conservacionistas de solo, com a finalidade de abatimento efetivo da erosão e da sedimentação; implantação de sistema de saneamento ambiental, com a finalidade de dar tratamento adequado ao abastecimento de água, tratamento de efluentes líquidos e disposição adequada dos resíduos sólidos das propriedades rurais; e, ainda, implantação e manutenção da cobertura vegetal das Áreas de Preservação Permanente.

Por sua vez, o funcionamento adequado de uma economia de mercado requer a efetiva tutela da liberdade de contratar. Para que os indivíduos realizem investimentos e façam surgir o pleno potencial das trocas por meio da especialização, faz-se necessária a redução nos custos associados a riscos futuros. É nesse sentido, que se observa, nas modalidades contratuais nas operações de serviços ambientais, a existência da tutela de liberdade de contratar e a potencialidade das trocas por meio da especialização que o mercado exige.

Também, é possível perceber que, embora tenham sua importância, os mecanismos de mercado nem sempre são garantidores de conservação dos serviços ambientais, principalmente, porque os mercados são incipientes para esses serviços, em face da definição de um direito claro de propriedade, que tem contribuído fortemente para a degradação ambiental. Além disso, mesmo na existência desse mercado para um serviço ambiental, os resultados obtidos pela ação podem ser social ou ecologicamente indesejáveis.

$\mathrm{Na}$ linha de argumentação de Coase (1991), as imperfeições de mercado de serviços ambientais consistem na existência de custos relacionados à utilização de contratos de 
execução instantânea, em razão dos quais surgem incentivos para os agentes econômicos estabelecerem novas formas de organização da atividade econômica capazes de evitar esses custos. Dentre esses custos de utilização do mercado, denominados custos de transação, os mais evidentes decorrem da necessidade de se descobrirem quais os preços no mercado de serviços ambientais.

Nesse sentido, nos projetos percebem-se altos custos na busca de informações, assim como custos relacionados à negociação, à celebração de contrato e ao monitoramento decorrentes dessa relação contratual. Dessa forma, os projetos ora desenvolvidos possuem custos de transação elevados, principalmente, relacionados à busca de informações sobre os serviços ambientais, à negociação de contratos e aos custos de monitoramento da execução desses contratos em cumprir com os objetivos das organizações envolvidas e da própria sociedade.

Sob a ótica do direito de propriedade - direito sobre os recursos ambientais -, procurou-se analisar como esse direito contribui para afetar o comportamento dos agentes econômicos e o desenvolvimento dos mercados de serviços ambientais. Haveria um direito absoluto sobre todos os aspectos? No que se refere ao recurso ambiental água, percebe-se que, nos projetos analisados, os direitos de propriedades não são absolutos, entretanto, os custos em proteger cada direito são crescentes no nível de segurança desejado, de modo que se torna inviável a obtenção do direito de propriedade perfeitamente seguro.

Assim, percebe-se nos projetos que o direito de propriedade tem clara sua definição, entretanto, existe a possibilidade de que ocorram as vendas ou transferências pelo pagamento dos serviços ambientais, e que os recursos decorrentes sejam direcionados ao uso efetivo e capaz de gerar o bem-estar da própria sociedade.

Em relação aos serviços ambientais, as instituições têm implicações importantes. As leis que embasam a relação contratual dos projetos foram criadas objetivando a redução potencial dos conflitos e impostas para induzir os agentes econômicos a agirem de forma mais eficiente, sem, contudo, deixar de levar em relação as instituições formais e informais e os próprios costumes regionais, tão necessários ao desenvolvimento das atividades dos serviços ambientais.

Por sua vez, a criação de oportunidades em áreas específicas pode criar fortes incentivos 
econômicos para a manutenção de serviços ambientais. Porém, mal geridas, essas atividades podem degradar os próprios recursos nos quais elas estão baseadas. Finalmente, os mercados muitas vezes são incapazes de responder a questões de promoção de igualdade associadas à gestão das gerações presente e futuras, dado que algumas mudanças nos serviços ambientais são irreversíveis.

Uma característica importante foi a constatação de que os compradores do serviço ambiental podem ser representados pelas pessoas que estão envolvidas em questões ambientais, sejam os participantes de Organizações Não Governamentais (ONGs), sejam pessoas movidas por questões de ética ou conscientização individual que se dispõem a apostar no desenvolvimento das políticas do meio ambiente; podem ser também empresas que buscam diferenciais no mercado por meio do envolvimento em projetos de PSA, com a intenção de promover seus produtos ou serviços com o selo de sustentabilidade. Também se identificou uma forte presença do estado, neste caso, representado pelos municípios com financiamento de recursos para pagamento pelo serviço ambiental, ou estado atuando como participantes dos projetos.

Outra característica visualizada em todos os projetos estudados da água foi a adoção do custo de oportunidade para avaliação e pagamento do serviço ambiental prestado pelos produtores. Nesse contexto, verifica-se que, nos projetos de água pesquisados, a começar pelo Conservador de Água - Extrema, identificam-se funções claras, que são manter a qualidade dos mananciais de Extrema e promover a adequação ambiental das propriedades rurais, priorizando uma ação mais preventiva do que corretiva, com fonte de financiamento com particularidades claras das entidades responsáveis, para suprir os recursos necessários para atingir os objetivos previamente traçados. O projeto é desenvolvido em nível local, no âmbito do município de Extrema.

O projeto apresentou dificuldade porque não havia no Brasil outro projeto de PSA em execução, sendo necessário desenvolver toda a metodologia e as ações, e, ao mesmo tempo, convencer as pessoas e as instituições de que o projeto tinha chances sucesso. E, ainda, em futuro próximo, a falta de agentes financeiros para dar a continuidade e o aperfeiçoamento das atividades de prestação de serviços ambientais. Nota-se o pioneirismo na implantação do modelo, principalmente, a adoção de uma metodologia adequada e a capacitação de pessoas envolvidas no projeto de execução. 
Identificou-se que os agentes produtores rurais estão satisfeitos e, hoje, os próprios produtores rurais estão dispostos a participar do projeto. Isso porque, de alguma forma, é perceptível a contribuição do aumento de renda dos produtores rurais, "pioneiros de Extrema", com sua adesão contratual. Assim, em termos gerais, o projeto Extrema apresenta o ambiente institucional plenamente definido com "regras do jogo" formais, capazes de diminuir as incertezas e estabelecer a base sustentável aos participantes dessa relação contratual. É o caso de os produtores rurais se encontrarem seguros nessa relação e, dessa maneira, percebe-se que estão agindo com ética no cumprimento dessas regras. Na mesma linha, os arranjos institucionais que fazem parte do contrato permitem a implantação e o funcionamento do projeto com metodologia adequada, embora incipiente, sem comprometer o desenvolvimento e atingir os objetivos previamente traçados.

No Projeto Produtores de Água e Florestas - Guandu, desenvolvido em nível local de município, percebeu-se que a proposta é a produção de águas e conservação de florestas visando à manutenção e ao aumento da quantidade de recursos hídricos da bacia do Guandu, com foco na melhoria dos indicadores de qualidade, na redução de sedimentação, no aumento da cobertura florestal associada à adequação ambiental de propriedades rurais e na geração de emprego e renda na bacia. Destacam-se, dentre os objetivos, gerar sustentabilidade socioeconômica e ambiental na sub-bacia do Rio das Pedras e estendê-la para as áreas prioritárias da Bacia do Rio Guandu; difundir o conceito de pagamento por serviços ambientais promovendo sua replicação; e, ainda, a conservação 3.450 hectares e a restauração de outros 275 .

O projeto estabelece sistema de pagamentos por serviços ambientais incentivados, mediante compensação financeira, pelo qual os agentes produtores rurais que, comprovadamente, adotarem, contribuírem ou implementarem práticas ou ações para a proteção e recuperação de mananciais, com auxílio à recuperação do potencial de geração de serviços ecossistêmicos, e provendo benefícios às bacias hidrográficas e às populações, podem prover os recursos hídricos para abastecimento da região metropolitana do Rio de Janeiro.

O ambiente institucional está plenamente definido como formal, capaz de diminuir as incertezas e estabelecer base sustentável aos participantes dessa relação contratual. $\mathrm{O}$ arranjo institucional para o desenvolvimento do projeto foi a criação da Unidade Gestora do Projeto (UGP), determinado pelo TCT, e cada instituição assumiu funções e atribuições específicas. 
Para a formatação e a construção do projeto, foi realizado um estudo de reconhecimento da estrutura fundiária, social e agrícola do local, o que possibilitou a identificação da cobertura vegetal, das áreas de preservação e das reservas legais no território da bacia. O pagamento pelos serviços prestados aos produtores rurais foi denominado no projeto como apoio financeiro concedido aos proprietários rurais habilitados. O poder executivo está autorizado a prestar esse apoio financeiro aos proprietários rurais habilitados que aderirem ao projeto, e que os pagamentos serão aos proprietários das reservas de preservação permanente legalmente, constituídas e situadas no município de Rio Claro - RJ.

Assim, em termos gerais, este projeto apresenta o ambiente institucional plenamente definido, sendo capaz de diminuir as incertezas e estabelecer a base sustentável aos participantes dessa relação contratual. $\mathrm{Na}$ mesma linha, os arranjos institucionais que fazem parte do contrato permitem a implantação e o funcionamento do projeto com metodologia adequada, embora incipiente, sem comprometer o desenvolvimento e atingir os objetivos previamente traçados.

No Projeto Produtores de Água na Bacia Hidrográfica Piracicaba/Capivari/Jundiaí - PCJ, desenvolvido em nível local de município, identificou-se que a proposta foi desenhada para ser um instrumento econômico estimulante à adoção das boas práticas com a priorização dos recursos hídricos, sem, contudo, deixar de observar os impactos em outros serviços tais como a conservação, a recuperação da diversidade biológica, e a fixação de carbono. $\mathrm{O}$ foco do projeto é a manutenção da regularidade de fluxo e qualidade de água do Sistema Cantareira. Destaca-se, dentre os objetivos, reduzir a poluição difusa rural, por meio do incentivo à adoção de práticas eficazes e sustentáveis; prover água de melhor qualidade para os usuários; conscientizar os produtores e consumidores sobre a importância do manejo integrado de bacias hidrográficas; compensar os produtores participantes com a geração da sustentabilidade socioeconômica e ambiental inicialmente nas sub-bacias do Rio Ribeirão Cancan e Ribeirão Moinho, difundindo o conceito de pagamento por serviços ambientais e promovendo sua replicação.

Este projeto prevê a adaptação de PSA já existente no município de Extrema, com a diferença apenas na fórmula de pagamento, já que o projeto de Extrema efetua o pagamento de valor fixo por hectare de acordo com o tamanho da propriedade, enquanto este leva em consideração os valores de referência dedicados a intervenções específicas, ou seja, efetua o pagamento de acordo com a conservação realizada pelo produtor. 
O sistema de pagamentos por serviços ambientais ocorre mediante compensação financeira, e os agentes produtores rurais que, comprovadamente, adotarem, contribuírem ou implementarem práticas ou ações para a proteção e recuperação de mananciais, com auxílio à recuperação do potencial de geração de serviços ambientais, e provendo benefícios às bacias hidrográficas e às populações, podem prover os recursos hídricos para abastecimento da região metropolitana de São Paulo.

O ambiente institucional, neste projeto, não está plenamente definido como formal, apesar disso estabelece uma base sustentável aos participantes dessa relação contratual. O arranjo institucional para o desenvolvimento do projeto foi a criação da Unidade de Gestão do Projeto (UGP), que é um colegiado formado por representantes de cada uma das entidades participantes, cada uma delas assumindo funções e atribuições específicas.

Para a formatação e a construção do projeto, foi realizado um estudo de reconhecimento da estrutura fundiária, social e agrícola do local, o que possibilitou a identificação da cobertura vegetal, áreas de preservação e reservas legais no território da bacia. O pagamento pelos serviços prestados aos produtores rurais ocorrerá somente após a constatação pela equipe técnica do projeto de que as atividades previstas nos planos de trabalho acordados foram cumpridas e estejam bem executadas. Os recursos financeiros utilizados para o pagamento dos produtores rurais são oriundos da cobrança da água, ou seja, recursos públicos repassados, geridos pelo Comitê da Bacia do PCJ. A lógica desse projeto é a do usuáriopagador.

Dessa forma, em termos gerais, este projeto apresenta o ambiente institucional que, apesar de não estar formalmente definido, é capaz de diminuir as incertezas e estabelecer a base sustentável aos participantes dessa relação contratual. Na mesma linha, os arranjos institucionais que fazem parte do contrato permitem a implantação e o funcionamento do projeto com metodologia adequada, embora incipiente, sem comprometer o desenvolvimento e atingir os objetivos previamente traçados.

A proposta do Projeto ProdutorES de Água, desenvolvido no Estado do Espírito Santo, é a melhoria da qualidade de água mediante o abatimento dos processos erosivos nas bacias dos rios Benevente, São José e Guandu. Diverso dos outros projetos de PSA de água, esse é um projeto de iniciativa estadual. Destaca-se, dentre os objetivos, criação de mecanismos de fazer 
retornar aos proprietários de áreas rurais, sensíveis sob o ponto de vista hidrológico, parte dos custos nos quais esses proprietários incorrem ao atuar como facilitadores para prestação de serviços de melhoria da qualidade de água, ou seja, a geração da sustentabilidade socioeconômica aos produtores que prestam o serviço ambiental de produção de água.

O projeto estabelece a recompensa financeira aos agentes produtores rurais que, comprovadamente, adotarem, contribuírem ou implementarem práticas ou ações para a proteção e a recuperação de mananciais, com auxílio à recuperação do potencial de geração de serviços ecossistêmicos, e provendo benefícios às bacias hidrográficas.

O ambiente institucional está plenamente definido sob o ponto de vista formal sendo capaz de diminuir as incertezas e estabelecendo uma base sustentável aos participantes dessa relação contratual, especialmente pela aprovação da lei estadual sobre pagamento por serviços ambientais. $\mathrm{O}$ arranjo institucional para a implantação do projeto foi formado por um conjunto de instituições, cada uma com funções e atribuições específicas, além do apoio do poder público estadual para a viabilização do projeto. Inclusive, a integração de programas e projetos governamentais e não governamentais é um dos pontos positivos destacado do projeto.

Para a formatação e a construção do projeto, foi realizado um estudo de reconhecimento da estrutura fundiária, social e agrícola do local, o que possibilitou a identificação da cobertura vegetal, áreas de preservação e reservas legais no território da bacia. Além disso, nesse projeto foram identificados os beneficiados pelos serviços ambientais prestados, com destaque para as concessionárias de hidroenergia e empresas de tratamento e distribuição de água potável.

O pagamento pelos serviços prestados aos produtores rurais tem o valor fixado em moeda corrente nacional fixado por hectare da propriedade, com ponderamentos técnicos e orçamentários de cada situação possível de ser contemplada pelo projeto. O repasse financeiro aos produtores rurais pelos serviços prestados ocorrerão somente após a constatação pela equipe técnica do projeto de que as atividades previstas nos planos de trabalho acordados foram cumpridas e estejam bem executadas. Os recursos financeiros utilizados para o pagamento dos produtores rurais são oriundos do FUNDÁGUA, que é um fundo financeiro público instituído por legislação específica, cujo principal objetivo é fornecer suporte à gestão 
de recursos hídricos no estado do Espírito Santo, ou seja, recursos públicos repassados a produtores rurais prestadores de serviços ambientais, participantes do projeto.

Assim, em termos gerais, este projeto apresenta ambiente institucional formalmente definido, sendo capaz de diminuir as incertezas e estabelecer a base sustentável aos participantes dessa relação contratual. Na mesma linha, os arranjos institucionais que fazem parte do contrato permitem a implantação e o funcionamento do projeto com metodologia adequada, embora incipiente, sem comprometer o desenvolvimento e atingir os objetivos previamente traçados.

Por fim, o Projeto Produtores de Água do Rio Camboriú, desenvolvido em nível local de município, tem como objetivo a criação de instrumentos, estratégias e metodologias que visem à melhoria da qualidade das águas na bacia do Rio Camboriú. Esse projeto, diverso dos demais, pois justificado pelo aumento de custo de tratamento da água, teve iniciativa da empresa que presta serviços de água e saneamento no município de Balneário Camboriú.

O projeto estabelece sistema de pagamentos por serviços ambientais incentivado, mediante compensação financeira, em que os agentes produtores rurais que, comprovadamente, adotarem, contribuírem ou implementarem práticas ou ações para a proteção e recuperação de mananciais, com auxílio à recuperação do potencial de geração de serviços ambientais, e provendo benefícios à bacia hidrográfica e às populações usuárias dessa água, podem prover os recursos hídricos para abastecimento da região metropolitana de Camboriú.

Da mesma forma, o ambiente institucional está plenamente definido como formal, capaz de diminuir as incertezas e estabelecer base sustentável aos participantes dessa relação contratual. $\mathrm{O}$ arranjo institucional para o desenvolvimento do projeto foi a criação de um Comitê Gestor do Projeto, e cada uma das instituições assumiu funções e atribuições específicas.

Para a construção e a formatação do projeto, foi realizado um levantamento socioeconômico baseado no cadastramento de propriedades rurais focalizando as cabecerias do Rio do Braço e Ribeirão dos Macacos, o que permitiu inclusive definir o valor para remuneração pela prestação dos serviços ambientais, que fez parte da legislação que instituiu valor-base de pagamento. Nesse levantamento, ocorreu a identificação da cobertura vegetal, as áreas de preservação e as reservas legais no território da bacia. 
O pagamento pelos serviços prestados aos produtores rurais habilitados que aderirem ao projeto ocorre somente após as vistorias das propriedades por equipe técnica

Em termos gerais, este projeto apresenta ambiente institucional formalmente definido com o regramento estabelecido em nível municipal, o que é capaz de diminuir as incertezas e estabelecer a base sustentável aos participantes dessa relação contratual. Na mesma linha, os arranjos institucionais que fazem parte do contrato permitem a implantação e o funcionamento do projeto com metodologia adequada, embora incipiente, sem comprometer o desenvolvimento e atingir os objetivos previamente traçados.

Para finalizar os resultados e discussões dos projetos de produção de água, é preciso fazer a análise dos itens de estabilidade institucional. No que se refere à análise do grau de estabilidade a partir do modelo proposto, os projetos de produção de água foram classificados segundo as categorias: estável, razoavelmente estável e instável. Essas categorias foram propostas levando em consideração o ambiente institucional, os arranjos institucionais, a participação da sociedade civil organizada e o tempo de duração do projeto, critérios justificados pelo fornecimento dos principais dados e informações suficientes para demonstrar o funcionamento do mercado dos serviços ambientais. No Quadro 12, é apresentada a classificação dos projetos segundo o grau de estabilidade.

Quadro 12 - Estabilidade institucional dos projetos de produção de água

\begin{tabular}{|l|c|c|c|}
\hline \multirow{2}{*}{\multicolumn{1}{|c|}{ Projetos }} & \multicolumn{3}{c|}{ CATEGORIAS } \\
\cline { 2 - 4 } & Estável & Razoavelmente Estável & Instável \\
\hline Conservador das Águas & $\mathrm{X}$ & $\mathrm{X}$ & \\
\hline Produtores de Água e Florestas - Guandu & & $\mathrm{X}$ & \\
\hline $\begin{array}{l}\text { Produtor de Água na Bacia Hidrográfica } \\
\text { Piracicaba/Capivari/Jundiaí/PCJ }\end{array}$ & & $\mathrm{X}$ & \\
\hline ProdutorES de Água & & $\mathrm{X}$ & \\
\hline Produtores de Água do Rio Camboriú & & & \\
\hline
\end{tabular}

Foram considerados projetos de produção de água estáveis o Projeto Conservador das Águas e Projeto ProdutorES. Essa classificação levou em consideração que ambos possuem legislações específicas criadas para o desenvolvimento do projeto, seus arranjos institucionais têm a participação de entidades públicas e privadas, e, ainda, há a participação de duas ou mais entidades da sociedade civil sem fins lucrativos. As entidades participantes do projeto Conservador das Águas são a TNC e a SOS Mata Atlântica; e do Projeto ProdutorES, as 
entidades IBIO, TNC e Instituto da Terra. Quanto ao tempo de duração, um dos itens de estabilidade institucional, ambos os projetos têm mais de cinco anos.

Os projetos Produtores de Água e Florestas - Guandu, Produtores de Água na Bacia do PCJ, e Produtores de Água do Rio Camboriú foram considerados razoavelmente estáveis e justificados individualmente a seguir.

O projeto Produtores de Água e Florestas - Guandu teve essa classificação, pois possui pelo menos dois dos itens dessa categoria, ou seja, a legislação específica para o desenvolvimento do projeto, e os arranjos institucionais (formais e informais) têm a participação de entidades públicas e privadas. Esse projeto tem seu tempo de duração de apenas cinco anos, um dos itens que impediram sua classificação como projeto estável.

O projeto Produtores de Água na Bacia do PCJ teve essa classificação, pois possui pelo menos dois dos itens dessa categoria, ou seja, tem a participação de entidades públicas e privadas nos arranjos institucionais (formais e informais), e tem a participação de uma entidade da sociedade civil sem fins lucrativos. Esse projeto tem seu tempo de duração de apenas cinco anos e não possui legislação específica para seu desenvolvimento, o que impediu sua classificação como projeto estável.

Finalmente, o projeto Produtores de Água do Rio Camboriú teve essa classificação, pois possui pelo menos dois dos itens dessa categoria, ou seja, tem uma legislação específica para o desenvolvimento do projeto, tem a participação de entidades públicas e privadas nos arranjos institucionais (formais e informais), e tem a participação de uma entidade da sociedade civil sem fins lucrativos. Esse projeto tem seu tempo de duração de apenas um ano, o que impediu sua classificação como projeto estável.

Por fim, nos projetos de produção de água analisados, segundo as categorias estabelecidas, não houve nenhum considerado instável.

\subsection{Dos projetos de PSA de carbono}




\subsubsection{Projeto Carbono Seguro}

O projeto carbono seguro é um projeto piloto e tem como foco o combate à degradação de florestas, buscando desenvolver um mecanismo de Redução das Emissões por Desmatamento e Degradação Evitados (REDD) para as condições regionais e não tem como objetivo a comercialização de créditos de carbono previsto no protocolo de Quioto, e, sim, ser um programa de desenvolvimento de tecnologia socioambiental.

O conceito de REDD parte da ideia de incluir na contabilidade das emissões de gases de efeito estufa aquelas que são evitadas pela redução do desmatamento e da degradação florestal. Nasceu de uma parceria entre pesquisadores brasileiros e americanos e originou uma proposta conhecida como "Redução Compensada de Emissões" (SANTILLI et al, 2000).

Segundo esse conceito, os países em desenvolvimento detentores de florestas tropicais, que conseguissem promover reduções de suas emissões nacionais oriundas de desmatamento receberiam compensação financeira internacional correspondente às emissões evitadas. $\mathrm{O}$ conceito de redução compensada tornou-se a base da discussão de REDD nos anos seguintes (IPAM, 2014).

O conceito de REDD, ampliado e atualmente conhecido como REDD+, refere-se à construção de um mecanismo, ou uma política, que deverá contemplar formas de prover incentivos positivos aos países em desenvolvimento que tomarem uma ou mais das seguintes ações para mitigação das mudanças climáticas: redução das emissões derivadas de desmatamento e degradação das florestas; aumento das reservas florestais de carbono; gestão sustentável das florestas; e conservação florestal. (PINTO et al, 2009). Algumas informações básicas são colhidas do responsável pelo programa, e de forma resumida, esclarece-se em continuidade.

O programa carbono seguro, como uma tecnologia socioambiental de REED, propõe gerar alternativa de renda aos produtores frente às atividades agropecuárias convencionais, a partir da manutenção da floresta em pé, e foi o primeiro do Brasil a criar reservas de carbono em áreas até então destinadas à produção agropecuária.

O serviço ambiental prestado pelo projeto é a fixação de carbono visando à mitigação climática, contribuindo também para a conservação dos recursos hídricos, da paisagem e da 
biodiversidade, serviços prestados de forma global e difusa, sendo os benefícios advindos da conservação e do incremento do estoque de carbono de uma floresta tropical compartilhados em dimensão mundial.

Sá et al, 2012 destacam que os objetivos do projeto são:

a) estruturar a tecnologia socioambiental do carbono seguro;

b) implementar a tecnologia socioambiental de Mata Atlântica e preservadas;

c) implementar um fundo para captação de recursos;

d) preservar as florestas nas propriedades contratadas;

e) evitar emissões de gases de efeito estufa para a atmosfera, advindas do desmatamento e da degradação das florestas;

f) promover a adesão dos proprietários ao programa e aos conhecimentos, atitudes e práticas socioambientais;

g) garantir uma estrutura básica financeira para a captação e o repasse de recursos;

h) estabelecer uma estrutura básica financeira para captação e o repasse de recursos;

i) estabelecer alianças, parcerias e redes convenientes ao andamento do programa.

O projeto surgiu e teve origem de uma parceria entre a OSCIP Iniciativa Verde ${ }^{110}$ e o Instituto Oikos de Agroecologia ${ }^{111}$, que firmaram um Convênio de Cooperação Técnica e Institucional com o objetivo de desenvolver um novo programa de mitigação no âmbito das mudanças climáticas por meio do desmatamento evitado, com a meta de criar reservas de carbono em áreas até então destinadas à pecuária leiteira. Dessa cooperação, nasceu o Programa Carbono Seguro como uma experiência que tem como parceira a Caixa Seguros, empresa ligada à Caixa Econômica Federal.

\footnotetext{
${ }^{110}$ Organização do terceiro setor que busca contribuir para a melhoria dos serviços ambientais como biodiversidade, água e qualidade do ar, ajuda na mitigação e na adaptação às mudanças climáticas causadas pelas atividades humanas por meio de projetos próprios de recomposição florestal e em parceria com outras instituições. Acredita na importância da consistência e da atualização científica, direcionando seu trabalho para a geração e a difusão de conhecimento e também ao apoio à formulação e à implementação de políticas públicas que sejam capazes de garantir a conservação dos ecossistemas naturais e o bem-estar das comunidades rurais. INICIATIVA VERDE. Disponível em: <http://www.iniciativaverde.org.br/quem-somos-organizacao.php>. Acesso em: 15 jun. 2014.

${ }^{111}$ É uma associação sem fins lucrativos de direito privado, fundada em setembro de 2003, qualificado como OSCIP (Organização da Sociedade Civil de Interesse Público) pelo Ministério da Justiça, certificado como Entidade Ambientalista do Estado de São Paulo pela Secretaria do Meio Ambiente do Estado de São Paulo (CadEA), e sua sede está localizada na cidade de Lorena, no Vale do Paraíba, Estado de São Paulo. OIKOS AGROECOLOGIA. Disponível em: <http://www.institutooikos.org.br/o-instituto.html>. Acesso em: 10 jun. 2014.
} 
O projeto é implementado na microbacia de Ribeirão dos Macacos, localizada no Vale do Paraíba, nos municípios de Guaratinguetá e Lorena, no estado de São Paulo (SP), onde predomina a pecuária leiteira extensiva, sendo o arrendamento para silvicultura de eucalipto alternativa a essa atividade. (SÁ et al, 2012). O tamanho médio das propriedades no município de Lorena é de 85,2 hectares, conforme estudo desenvolvido pelo IEA em 2008, considerado segundo a Lei $\mathrm{n}^{\circ}$. 11.326 (BRASIL, 2006), como pequenas propriedades, pois o limite seria de 96 hectares (quatro módulos fiscais).

$\mathrm{O}$ arranjo institucional ${ }^{112}$ constituído para o desenvolvimento do projeto é formado pelas seguintes instituições, cada uma com suas funções definidas, a saber:

a) Caixa Seguros: empresa pública que atua no financiamento e no repasse integral dos custos do desenvolvimento do projeto, funcionado como um patrocinador;

b) Instituto Oikos de Agroecologia: entidade da sociedade civil que atua no apoio e no suporte técnico aos proprietários que aderiram ao projeto, por seu profundo conhecimento sobre as questões socioambientais e os atores da bacia; no mapeamento de uso das terras da microbacia; na indicação dos proprietários suscetíveis a adesão ao projeto; na restauração florestal em áreas ciliares degradadas na Bacia do Ribeirão dos Macacos, com o plantio de 16.670 mudas de espécies nativas; e na divulgação do programa e na avaliação das inscrições dos proprietários interessados;

c) Iniciativa Verde: entidade da sociedade civil que atua no apoio ao projeto, como responsável por firmar os contratos com os participantes e monitorar o cumprimento das condições necessárias ao pagamento; responsável por efetuar os pagamentos e monitorar os resultados referentes ao incremento dos estoques de carbono das florestas da bacia; responsável por divulgar o programa e avaliar as inscrições dos proprietários interessados.

A remuneração de cada proprietário rural, que receberá em dinheiro, é o equivalente ao carbono estocado na floresta de sua propriedade que exceder as Áreas de Preservação Permanentes (APP) e Reserva Legal (RL), conforme definição da legislação em vigor. A

\footnotetext{
${ }^{112} \mathrm{O}$ sentido utilizado aqui é aquele entre as unidades econômicas que administram o meio pelo qual tais unidades podem cooperar (...) ou podem fornecer um mecanismo que pode proporcionar uma mudança nas leis ou no direito de propriedade (WILLIAMSON, 1996).
} 
definição do valor a ser pago aos produtores no projeto foi estipulado arbitrariamente em US\$ 10 por tonelada de carbono (CO2), considerando a taxa de câmbio em 2009, quando da implantação do projeto, o valor ficou em R\$ 24,00/tCO2 (SÁ et al, 2012).

$\mathrm{Na}$ estruturação do projeto, foi assumido que o estoque potencial máximo de $\mathrm{CO} 2$ nas florestas da região é de 320 toneladas por hectare, sendo o valor potencial por hectare R\$ 7.680,00, partindo-se do pressuposto que, adotadas medidas de conservação dos fragmentos que garantam sua evolução estrutural e florística, as florestas atingirão esses estoques potenciais (SÁ et al, 2012).

Para que essas florestas atinjam a potencialidade desejada, foi estipulado o horizonte de 30 anos, por analogia aos períodos fixos de creditação de projetos florestais de Mecanismo de Desenvolvimento Limpo (MDL). Dessa maneira, dividindo o montante potencial por 30 anos, o valor anual inicial do projeto foi de $\mathrm{R} \$ 256,00$ por ano. (SÁ et al, 2012). O valor que o proprietário rural recebe é superior ao valor que receberia, caso optasse por desmatar o fragmento florestal e arrendasse a área para a atividade agropecuária.

Para a participação no projeto, é exigido: que a propriedade esteja, em primeiro lugar, localizada na bacia do Ribeirão dos Macacos; que o imóvel seja considerado como pequena propriedade, até 96 hectares; que tenha o emprego predominantemente de mão de obra familiar; que a renda provenha majoritariamente de atividade exercida na propriedade; que a propriedade possua vegetação que exceda a área de reserva legal $(20 \%$ da área da propriedade, excluídas as APPS); e que essas áreas de reserva legal estejam averbadas no Cartório de Registro de Imóveis. A prática a ser adotada pelos participantes é simplesmente a preservação de áreas de vegetação nativa. Como pré-requisito do Programa Carbono Seguro, as propriedades rurais potenciais necessitam conter um fragmento de vegetação nativa da Mata Atlântica excedente às áreas de APP e RL, além da documentação que comprove o título da propriedade rural e averbação da Reserva Legal.

O monitoramento do projeto é feito no mínimo anualmente para que seja comprovada a condição de conservação das florestas objeto do contrato. Se a avaliação for positiva, será efetuado o pagamento pelo serviço ambiental. Por outro lado, caso a avaliação seja negativa, o pagamento é suspenso até que as medidas de adequação sejam tomadas pelos proprietários. 
Neste projeto há previsão de que, em casos de as medidas não serem cabíveis, o contrato seja cancelado automaticamente.

O projeto teve o início de sua implantação em maio de 2009, com a seleção das propriedades já inseridas na área de atuação da organização do Instituto Oikos. Duas são as propriedades participantes do projeto. A primeira a aderir foi a $\square$ Fazenda das Palmeiras, com uma fração de terra de 79,13 hectares, localizada no município de Lorena e de propriedade da Sra. Marisa Camargo Nunes. Após levantamentos em campo, a avaliação geral da propriedade e a quantificação das áreas para atendimento das regras previstas na legislação sobre Reserva Legal e APPs, foi possível calcular e identificar a área excedente do fragmento, que totalizou 6 (seis) hectares. O contrato dessa propriedade foi assinado em novembro de 2009, e o primeiro pagamento ocorreu em novembro de 2010. A segunda a aderir foi a Fazenda São Sebastião localizada no município de Guaratinguetá e detentora de um fragmento florestal de 86,27 hectares, cujo proprietário é o Sr. José Vicente Junqueira Teberga. Utilizada a mesma metodologia, foi identificado excedente igual a 15 hectares. O contrato dessa propriedade foi assinado em março de 2010, e o primeiro pagamento ocorreu em 2011. As informações foram obtidas a partir dos contratos assinados.

A representação dos dados da evolução do projeto Carbono Seguro do período de 2009 a 2013 estão demonstrados na Tabela 6, e foram obtidos a partir dos contratos e controles de pagamentos.

Tabela 6 - Evolução projeto Carbono Seguro

\begin{tabular}{c|c|c|c|c}
\hline Período & $\mathbf{N}^{\mathbf{o}}$ de Contratos & $\begin{array}{c}\text { Área do Imóvel } \\
\text { ha }\end{array}$ & $\begin{array}{c}\text { Área Objeto do } \\
\text { Contrato ha }\end{array}$ & $\begin{array}{c}\text { Valor PSA Pago } \\
\text { (RS) }\end{array}$ \\
\hline 2010 & 01 & 79,13 & 6 & $1.536,00$ \\
\hline 2011 & 02 & 165,40 & 17 & $4.352,00$ \\
\hline 2012 & 02 & 165,40 & 17 & $4.352,00$ \\
\hline 2013 & 02 & 165,40 & 17 & $4.352,00$ \\
\hline
\end{tabular}

Fonte: Gestores do Projeto

Em função da restrição de recursos financeiros, não há previsão de ampliação do projeto, já que o recurso destinado do financiador atenderá apenas os dois produtores, explica o responsável pelo projeto.

Não foi identificada, para implementação do projeto, uma legislação específica. Tal fato foi justificado pelo responsável por ser um projeto piloto e estar envolvendo somente entidades 
de direito privado e com adesão voluntária dos participantes. A legislação utilizada pelo projeto é aquela que trata da definição de Reserva Legal e Áreas de Preservação Permanente. A discussão inicia-se em nível de participantes para que seja possível a expansão em termos de escala, devendo também necessitar de instrumentos legais para facilitar a gestão de recursos e critérios para sua aplicação.

$\mathrm{Na}$ avaliação do responsável, o projeto apresenta algumas limitações que precisam ser superadas para a evolução do programa, tais como a indisponibilidade de novos investimentos para financiar mais propriedades rurais da microbacia, que não tem permitido ampliar o número de proprietários rurais beneficiados e florestas preservadas; documentação irregular dos imóveis rurais, que na maioria das vezes encontram-se em situações que requerem algum tipo de intervenção (levantamento topográfico, resolução de litígios com vizinhos); custo potencial para realização do levantamento de serviços topográficos georreferenciados, necessário para a averbação da reserva legal, uma vez que, para participar do programa, o proprietário precisa ter averbada essa reserva.

Por fim, no que se refere à sustentabilidade financeira do projeto, três aspectos precisam ser levados em consideração: a identificação de novos financiadores, o preço adequado para a tonelada de $\mathrm{CO} 2$, e a forma de pagamento com seu escalonamento ao longo do tempo do contrato. Da mesma forma, o responsável afirma que o projeto sempre se colocou no campo do mercado voluntário e também não se propõe a gerar créditos de carbono, apesar de o pagamento estar lastreado nos estoques potenciais e no preço da tonelada de carbono florestal.

\subsubsection{Programa Suinocultura Sustentável Sadia (3S)}

O projeto de sustentabilidade com geração de crédito de carbono ${ }^{113}$ no sistema de integração prevê a instalação de biodigestores para o aproveitamento de dejetos nas propriedades dos produtores integrados ${ }^{114}$ da empresa privada BR Foods, e foi desenvolvido pelo Instituto

\footnotetext{
${ }^{113}$ Em 2013, o programa chegou a um redução de 360.000 toneladas de CO2. BRF RELATÓRIO ANUAL DE SUSTENTABILIDADE, 2013.2 Disponível em: <http://www.brasilfoods.com/ri/siteri/web/arquivos/BRF\%20RA\%20PT\%20140609.pdf $>$. Acesso em 30 abr. 2014

${ }^{114}$ São fornecedores exclusivos da BR Foods que recebem ração e assistência técnica da empresa, afirma o coordenador.
} 
Sadia, entidade da sociedade civil, sem fins lucrativos, criada em dezembro de 2004, que visa promover o desenvolvimento sustentável.

O projeto teve como origem o despertar da empresa para o potencial de geração de projetos de créditos de carbono no ano de 2002. Já em 2003, iniciou-se o diagnóstico interno para avaliar as possibilidades existentes para o desenvolvimento e a implementação de projetos de carbono. A partir disso, foram selecionadas três granjas próprias para a instalação dos biodigestores para o tratamento dos resíduos da suinocultura. Em 2005, após a criação do Instituto Sadia e a experiência dos biodigestores em suas granjas próprias, dá-se início à implantação do Programa Suinocultura Sustentável Sadia 3S para os produtores integrados.

O projeto teve sua criação com adesão voluntária dos produtores integrados, sendo ofertada a todos os integrados e prevê a instalação de biodigestores em regime de comodato ${ }^{115}$ nas granjas participantes, para reduzir a emissão de gás metano. A previsão inicial era de que o investimento realizado fosse pago por meio da comercialização de créditos de carbono, de acordo com a viabilidade econômica de cada suinocultor.

É natural que a produção de suínos gere impactos ambientais, então, a empresa sentiu-se comprometida em adequar e manter a produção adequada ambientalmente, além disso, segundo o coordenador, o consumidor é exigente e cobra de fato uma postura condizente com a atualidade.

A partir disso, o programa prevê também a disseminação de novas tecnologias, melhorias ambientais, melhores práticas e aumento da sustentabilidade das granjas. Assim, foram definidos como objetivos do programa: reduzir impactos ambientais; promover a sustentabilidade produtores de suínos; reduzir as emissões de gases do efeito estufa; e comercializar os créditos de carbono.

A Figura 8 mostra o funcionamento do programa.

\footnotetext{
${ }^{115}$ Contrato por cessão gratuita prevista no art. 579 do Código Civil (BRASIL, 2002).
} 


\section{Funcionamento do Programa 3S

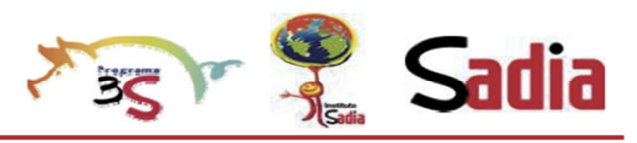

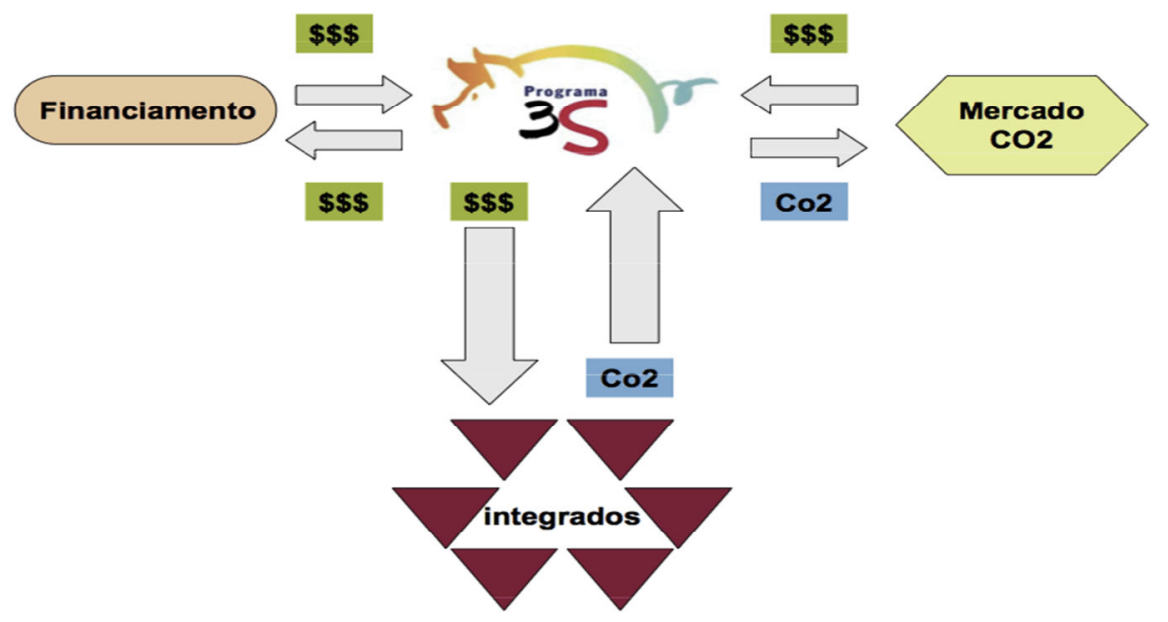

Figura 8 - Funcionamento do Programa 3S FONTE: ROSSATO; BELLAVER, 2011.

Para melhor compreensão do programa, o fluxograma no produtor integrado com a respectiva captura do carbono poderá ser visualizado na Figura 9, a seguir.
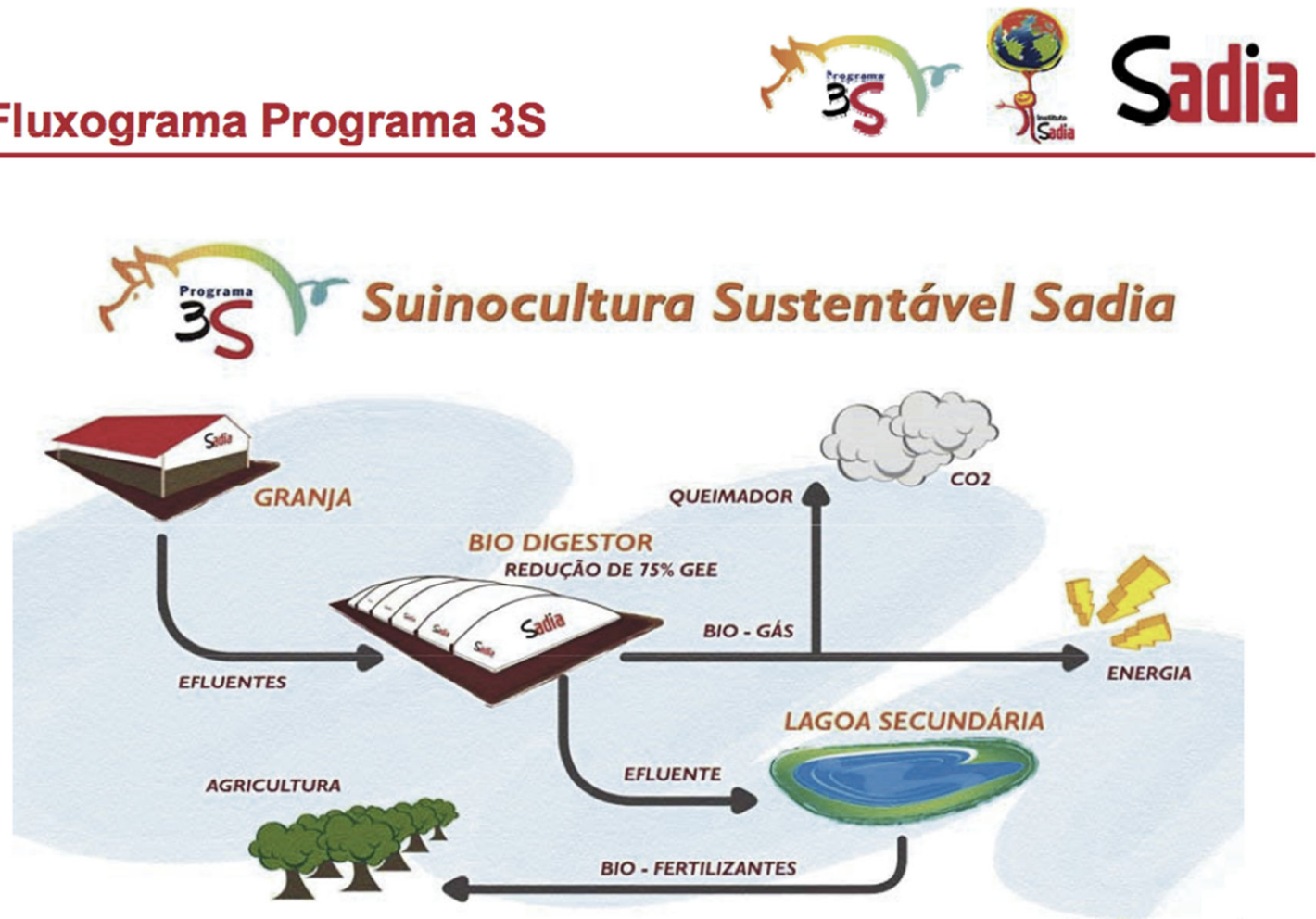

Figura 9 - Fluxograma Programa 3 S FONTE: ROSSATO; BELLAVER, 2011. 
O coordenador exemplifica o funcionamento do projeto por meio do exemplo de um produtor integrado que mantém uma granja de médio porte, com dois biodigestores instalados, voltada à produção de leitões, localizado no município de Toledo (SC), que entrou no programa em 2006. Somados os galpões, as atividades e os animais, a granja produz cerca de 43 mil litros de dejetos por dia. O líquido escorre pela tubulação subterrânea até uma baixada. Ao lado de cada biodigestor, foram instalados queimadores, que se alimentam do biogás. Dessa queima tem origem o ganho ambiental, com a destruição do metano, gerando o serviço ambiental de captura de carbono, conhecido como o produto ecológico de crédito de carbono.

Para contabilizar a redução de poluentes em cada propriedade, os queimadores contam com um equipamento eletrônico que, ao longo do dia, registra o volume de gases que está sendo queimado. As informações alimentam um banco de dados que contém todas as informações dos biodigestores e da queima individualizada para cada integrado.

Os produtores do projeto também podem aproveitar o biogás para movimentar motores ou gerar eletricidade, que precisa ser acoplado ao contador de metano para que o projeto continue recebendo os créditos de carbono. Mas, nesse caso, o investimento deve ser bancado pelo próprio criador, afirma o coordenador.

O programa tem sua atuação em Concórdia (SC), com 357 integrados e 368 biodigestores instalados; em Três Passos (RS), com 193 integrados e 202 biodigestores instalados; em Toledo (PR), com 400 integrados e 415 biodigestores instalados; em Uberlândia (MG), com 115 integrados e 222 biodigestores instalados; e em Lucas do Rio Verde (MT), com 29 integrados e 163 biodigestores instalados (ROSSATO, BELLAVER, 2011).

Todo o custo, inclusive de instalação, é financiado pelo projeto, ou seja, o produtor não tem nenhum desembolso. Os recursos para o desenvolvimento do projeto foram obtidos por meio do financiamento do BNDES, sendo gastos para os projetos das cidades de Concórdia (SC), Três Passos (RS), Toledo (PR) e Uberlândia (MG) em torno de R\$ 60,5 milhões. Já para os integrados de Lucas de Rio Verde (MT), o valor do financiamento do BNDES foi de R\$28,3 milhões. Existe um contrato futuro para o projeto de 2.460 .000 toneladas de $\mathrm{CO} 2$ junto a European Carbon Fund (ECF) ${ }^{116}$. O registro do projeto $3 \mathrm{~S}$ ocorreu na ONU, em 29 de maio

\footnotetext{
${ }^{116}$ É fundo criado em 2005 por dois dos maiores bancos europeus, o francês Caisse des Dépôts e o belga-alemão Fortis Bank, e dirigido pela IXIS Enviroement \& Infrastructures, que conta com aportes de diversas instituições
} 
de 2009. Em 20 de agosto de 2010, ocorreram 960 registros de propriedades e, em 20 de março de 2011, mais 90 (ROSSATO; BELLAVER, 2011).

A previsão era de que a venda dos créditos de carbono seria utilizada inicialmente para o pagamento de todos os investimentos realizados para o projeto, que foram financiados pelo BNDES. Após o pagamento dos investimentos do projeto, os recursos da venda dos créditos de carbono seriam repassados aos produtores na proporção da redução dos gases de efeitos estufa de cada propriedade. O biodigestor de uma de granja média, com dois mil animais em engorda, poderia gerar algo perto de $\mathrm{R} \$ 15$ mil por ano com a venda de créditos de carbono, considerados os preços da tonelada de carbono à época do início do projeto. No entanto, o programa não arriscou uma previsão de quanto tempo vai precisar para pagar os investimentos em cada granja. Tudo depende do volume de metano queimado e do preço da tonelada de crédito de carbono, que varia muito no mercado internacional.

A escolha o Mecanismo de Desenvolvimento Limpo Programático ${ }^{117}(\mathrm{PoA})^{118}$ justificou-se por ser um único registro para todo o projeto, sem limites de emissão para o grupo, com flexibilidade em tempo e espaço, e ainda cada granja de integrado é um CPA ${ }^{119}$ independente do outro. Além disso, poderão ocorrer vários registros para o projeto e o produtor integrado não pode entrar nem sair por 10 anos. As etapas de creditação do carbono para o projeto podem ser observadas na Figura 10, a seguir.

\footnotetext{
financeiras. $\quad$ SUINOCULTURA INDUSTRIAL. http://www.suinoculturaindustrial.com.br/noticia/sadia-e-instituto-sadia-de-sustentabilidade-formalizamprimeira-venda-de-creditos-de-carbono/20060526082206_19908. Acesso em 03 jun. 2014.

${ }^{117}$ Considerado uma evolução em relação ao MDL tradicional, o MDL Programático, ou Programa de Atividades no Âmbito do Mecanismo de Desenvolvimento Limpo (PoA), permite que um grupo de pequenos projetos de redução de emissões ou de sequestro de gases de efeito estufa (GEE) que apresentem a mesma metodologia, sejam registrados como atividade de MDL única, em diferentes períodos e localidades. Para isso, determinadas condições devem ser atendidas. Com o PoA, atividades de projeto podem ser agrupadas em uma única atividade de MDL. Assim, o PoA pode ser definido como um contrato "guarda-chuva" que hospeda várias atividades programáticas no âmbito do MDL. Isto implica menores custos, menos burocracia e possibilita que pequenos projetos sejam implementados e mais créditos de carbono sejam gerados (CARBONO, 2012).

118 A BR Foods foi a primeira empresa do setor alimentício a registrar na ONU (Organizações das Nações Unidades) um projeto de desenvolvimento limpo programático (PoA).

${ }^{119}$ Corresponde à data de início de uma atividade programática no âmbito do MDL (MDL EXECUTIVO Convenção-Quadro das Nações Unidas sobre Mudança do Clima (CQNUMC). CARBONO. Disponível em: $<$ http://carbono.brasilcooperativo.coop.br/sites/1400/1480/00000084.pdf $>$. Acesso em: 27 jun. 2014.
} 


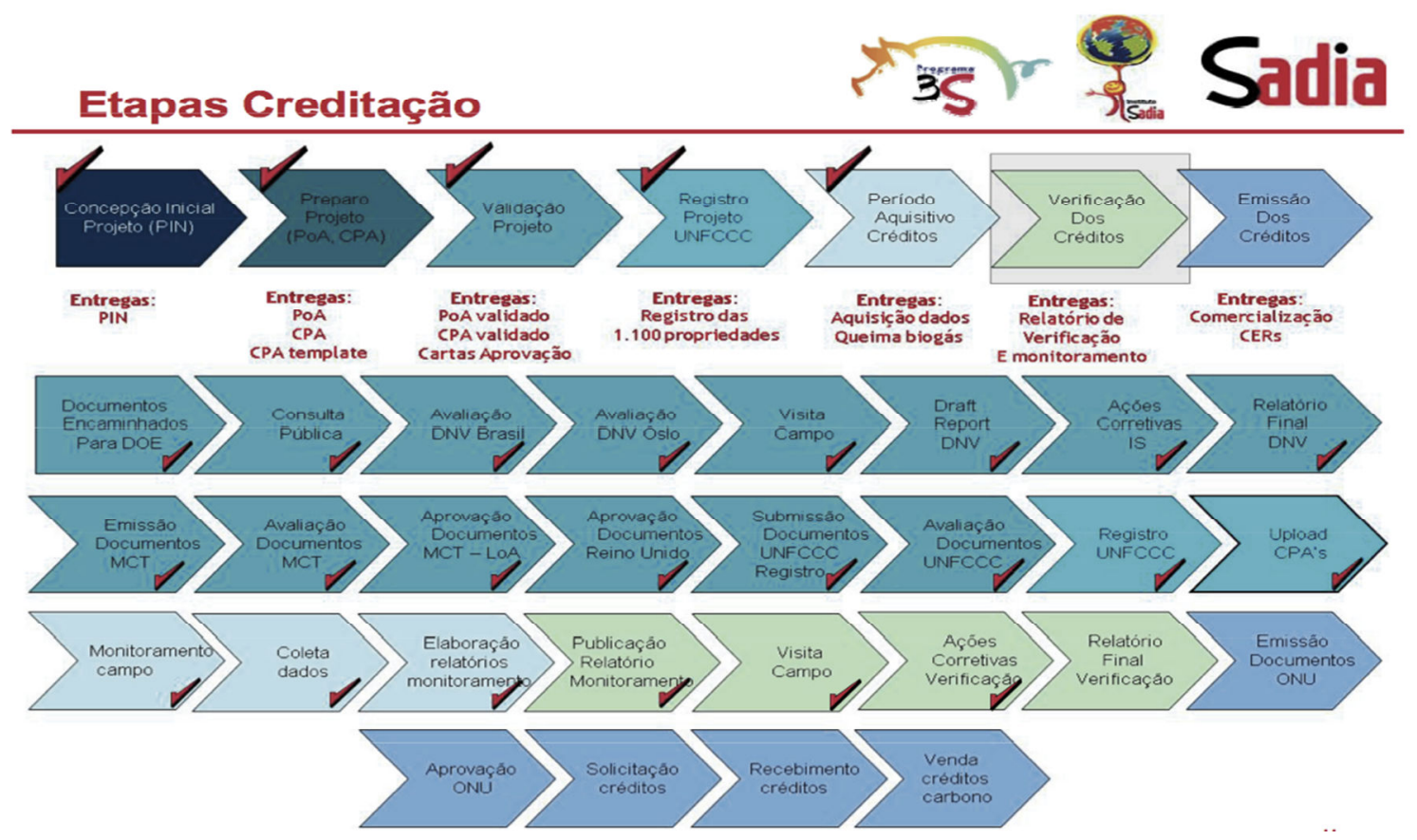

Figura 10 - Etapas de Creditação Programa $3 \mathrm{~S}$

FONTE: ROSSATO, BELLAVER, 2011

O propósito do programa era que a agroindústria não tivesse lucro com a iniciativa, mas também não pretendia ter prejuízo, por isso a proposta era que todos os custos do programa fossem pagos com o valor obtido da venda dos créditos de carbono justamente com a redução da poluição. A primeira venda de certificados ocorreu em 2011 e foi para um fundo de compradores da Europa.

Atualmente, segundo declarações da coordenação do projeto, essa comercialização de créditos está prejudicada dada a baixa procura no mercado internacional, provocada especialmente, na sua visão, pela falta de renovação, em 2012, do compromisso assumido no protocolo de Quioto, ou seja, alguns países que assinaram o protocolo em 2005, não o renovaram em 2012. Talvez o motivo tenha sido que, a partir da crise de 2008, esses países estivessem cumprindo suas metas pela redução de suas produções em sua própria casa.

Outro fato destacado pela coordenação do projeto diz respeito ao baixo ${ }^{120}$ valor pago pela tonelada do crédito de carbono mercado internacional, esse valor não cobre os custos dos projetos.

\footnotetext{
120 Atualmente varia entre nove a doze dólares a tonelada. BIODIESEL.BR.COM. Disponível em: < http://www.biodieselbr.com> . Acesso em 20 jul. 2014
} 
Esse projeto permitiu, ainda, que os participantes pudessem produzir fertilizantes, pois de um lado está o biodigestor e de outro o biofertilizante, que é utilizado para adubação de culturas como lavoura de milho e o cultivo de capim tifton, ambos usados na alimentação do gado leiteiro. O responsável destaca que esse tipo de adubo tem algumas vantagens em relação ao esterco convencional. Por ser mais suave, ele não queima as folhas do capim e pode ser aplicado por cima do pasto. Outra diferença é que os nutrientes do biofertilizante são absorvidos com mais facilidade pelas plantas. Ele ressalta que sempre é recomendado o cuidado com a análise do solo, pois o excesso também pode causar problemas de contaminação. Outros produtores estão utilizando o biofertilizante para o cultivo do milho e reconhecem que ocorreram vantagens em seu cultivo e na formação da cilagem, além da redução de gastos com adubo. Os produtores também estão utilizando os biodigestores para produção de energia elétrica a partir da geração de biogás, neste caso, o custo dos equipamentos é por conta deles. Todas essas melhorias refletiram no aumento da produtividade do gado leiteiro e consequente ganho ao produtor integrado.

$\mathrm{Na}$ avaliação do coordenador, os resultados obtidos com o projeto já dão sinais de sucesso da iniciativa visto serem perceptíveis: aumento da capacidade de geração de renda com os produtos alternativos (biofertilizantes, biogás); benefício tecnológico-ambiental com as novas tecnologias de tratamento e adequação ambiental que promovem a melhoria da qualidade da propriedade, a redução das emissões dos gases de efeito estufa na atmosfera; benefício ambiental local com a redução de odor na propriedade, redução de vetores nas propriedades (insetos, moscas, ratos) e melhoria na qualidade ambiental da propriedade; e benefício econômico-social com a fixação nas atividades e na agricultura, diminuição da quantidade de energia utilizada e diversificação nas propriedades. O benefício econômico da geração de crédito do carbono, viabilizador do projeto, que geraria renda extra para contribuição da sustentabilidade, resta prejudicado pela situação do mercado de créditos de carbono: baixo valor pago pela tonelada, que atualmente não paga os custos para a manutenção do programa, o que levou a empresa a assumir todos os custos do projeto.

O coordenador destaca, ainda, algumas limitações e dificuldades do projeto, tais como o acesso real às linhas de créditos para projetos de MDL, a falta de incentivo tributário para tecnologias e equipamentos nacionais utilizados na economia de baixo carbono e para a importação de equipamentos e tecnologias para projetos na economia do baixo carbono. Mas a principal delas é o baixo valor da tonelada de carbono pago atualmente pelo mercado 
internacional que não cobre os custos de sua operacionalização.

Por fim, apesar da situação do projeto, a empresa assumiu os financiamentos e arcou com o custo do projeto, mantendo os biodigestores, já instalados, em funcionamento, mas o objetivo de instalação em todos os seus produtores integrados, nesse momento, não é a intenção da empresa, pelo menos nesse formato de projeto.

\subsubsection{Dos resultados e discussões dos projetos de carbono}

A partir dos dados obtidos por meio do modelo de descrição de cada projeto e após a consolidação dessas informações, serão abordados, neste item, os resultados e as discussões dos projetos de PSA de captura de carbono, sob o ponto de vista da teoria da nova economia institucional, abordando o ambiente institucional, os arranjos institucionais com as funções de cada instituição, a metodologia de remuneração dos serviços ambientais, as fontes de recursos, o monitoramento e a percepção dos atores envolvidos.

Para facilitar essa análise, foram consolidados os dados de cada projeto no 13, do qual não constaram apenas as informações sobre o papel de cada instituição no projeto, informação já descrita no texto.

Quadro 13 - Resumo dos projetos de captura de carbono

\begin{tabular}{|c|c|c|}
\hline Projetos & Carbono Seguro & Programa 3S \\
\hline Instituições & Entidades da sociedade civil e empresa pública & Entidade da sociedade civil, empresa privada BR Foods, autarquia - BNDES. \\
\hline Ambiente Institucional & Sem legislação específica & Lei $\mathrm{n}^{0} .12 .187$, de 2009, sobre comercialização de crédito de carbono. \\
\hline Papel das Instituições & \multicolumn{2}{|c|}{ Estão dispostas na descrição de cada projeto } \\
\hline $\begin{array}{l}\text { Remuneração Serviços } \\
\text { Ambientais }\end{array}$ & $\begin{array}{l}\text { Valor da tonelada de carbono estocada estipulado } \\
\text { arbitrariamente }\end{array}$ & $\begin{array}{l}\text { Não há ainda identificação de quanto o produtor irá receber pois primeiro serão } \\
\text { pagos os investimentos do projeto. }\end{array}$ \\
\hline Fonte de Financiamentos & Recursos da Caixa Seguros & BNDES e venda de crédito de carbono. \\
\hline Monitoramento & Anual & $\begin{array}{l}\text { Diário por meio de equipamento eletrônico instalado em cada biodigestor que } \\
\text { alimenta o banco do dados }\end{array}$ \\
\hline Percepção dos Atores & $\begin{array}{l}\text { Limitações de recursos para expansão do projeto, } \\
\text { documentação irregular dos imóveis, altos custos de } \\
\text { levantamentos físicos } \\
\text { georreferenciamento). }\end{array}$ & $\begin{array}{l}\text { Melhora da renda produtor; benefício tecnológico-ambiental; benefício } \\
\text { ambiental, benefício econômico-social; } \\
\text { Limitações dificuldade de acesso real às linhas de créditos para projetos de } \\
\text { MDL, a falta incentivo tributário para tecnologias e equipamentos nacionais } \\
\text { utilizados na economia de baixo carbono, para importação de equipamentos e } \\
\text { tecnologias para projetos na economia do baixo carbono. }\end{array}$ \\
\hline
\end{tabular}

Os projetos de captura e fixação de carbono têm assumido importância no contexto atual de prestação de serviços ambientais, especialmente a partir do Protocolo de Quioto, despertando a atenção da sociedade e discussões nas diversas áreas de estudo, apesar da redução dos valores pagos pela tonelada de créditos de carbono no mercado internacional. 
Em ambos os projetos estudados, identificou-se um esforço pela sustentabilidade, como objetivo de alcance maior, a partir de trocas de interesses, com o envolvimento de pessoas qualificadas e empenhadas na efetiva prestação do serviço ambiental pelos produtores rurais. Por outro lado existem indivíduos (pessoas físicas ou jurídicas) com interesses particulares, que estão aptas financeiramente a comprar esses serviços, garantindo a manutenção e o processo de desenvolvimento da sustentável.

Como parte integrante dessas relações contratuais, encontram-se os produtores proprietários rurais, que são incentivados a aderir aos projetos de pagamento por serviços ambientais de captura de carbono desenvolvidos por entidades públicas ou privadas, inicialmente, por motivações financeiras, para executarem ações ou tarefas, como a adoção de práticas conservacionistas de manutenção da floresta em pé, com o cuidado e a preservação da cobertura vegetal existente especialmente nas áreas de preservação permanente e reserva legal.

A partir dos casos de carbono estudados e pela similariedade com os projetos desenvolvido para água, foi possível perceber que, embora tenham sua importância sob o ponto de vista ambiental, os mecanismos de mercado nem sempre são garantidores da prestação dos serviços ambientais, principalmente, porque os mercados são incipientes para esses serviços, em face da indefinição de um direito claro de propriedade, que tem contribuído fortemente para a degradação ambiental.

Apesar de tratarem da prestação do serviço ambiental de captura de carbono, ambos os projetos utilizam mecanismos diversos: enquanto o Projeto Carbono Seguro é um programa de desenvolvimento de tecnologia socioambiental, o Programa $3 \mathrm{~S}$ tem como objetivo a comercialização de créditos de carbono, com fundamentação no Protocolo de Quioto.

Esse mecanismo os torna diferenciados em vários aspectos, ou seja, no caso do serviço ambiental de carbono, é possível a formatação de projeto de pagamento pelo serviço ambiental com estruturas e finalidades diversas, com o mesmo fim, que é a preservação da floresta para a prestação do serviço ambiental.

Uma característica comum em ambos os projetos do carbono diz respeito aos prestadores do serviço ambiental, os produtores rurais, que são parte fundamental para o desenvolvimento de 
cada um dos projetos. Esses produtores podem aderir aos projetos de maneira voluntária e sua atuação é decisiva na efetiva prestação do serviço ambiental, e como consequência são remunerados pelo serviço prestado, o que de certa forma os motiva, já que esses projetos podem contribuir para o aumento de sua renda a partir da adesão contratual aos projetos.

Nesse contexto, o Projeto Carbono Seguro tem como foco o combate à degradação de florestas, procurando desenvolver um mecanismo de redução das emissões por desmatamento e degradação evitados, propondo a geração alternativa de renda ao produtor a partir da manutenção da floresta em pé. Dentre os objetivos do projeto, estão a implementação da tecnologia socioambiental de Mata Atlântica e preservadas; a implementação de um fundo para captação de recursos; a preservação das florestas nas propriedades contratadas; as emissões evitadas de gases de efeito estufa para a atmosfera, advindas do desmatamento e da degradação das florestas; o estabelecimento e garantia de uma estrutura básica financeira para a captação e o repasse de recursos, e a promoção e a adesão dos proprietários ao programa e aos conhecimentos, de práticas e atitudes socioambientais.

Percebe-se que o projeto Carbono Seguro, apesar de não apresentar um ambiente institucional plenamente formalizado e definido com "regras do jogo" formais, é capaz de reduzir as incertezas e estabelecer a base sustentável aos participantes do projeto por meio da relação contratual. É o caso de os produtores rurais se encontrarem seguros nessa relação e, dessa maneira, agirem com ética no cumprimento dessas regras.

$\mathrm{Na}$ mesma linha, os arranjos institucionais que fazem parte desse projeto permitem sua implantação e seu funcionamento com metodologia adequada, embora incipiente, sem comprometer o desenvolvimento e atingir os objetivos previamente traçados. No arranjo institucional construído para o projeto Carbono Seguro, é notória a ação e o envolvimento de Organizações Não Governamentais (ONGs) formadas por pessoas movidas por questões de ética ou conscientização individual, que se dispõem a apostar no desenvolvimento das políticas do meio ambiente. Chamou atenção o número reduzido de entidades envolvidas, duas organizações não governamentais e uma instituição pública financiadora.

O projeto estabelece sistema de pagamentos por serviços ambientais de captura de carbono incentivado, mediante compensação financeira, pelo qual os produtores rurais que, comprovadamente, adotarem, contribuírem ou implementarem práticas ou ações de 
manutenção e preservação da floresta receberão pelos serviços prestados. A remuneração que cada proprietário receberá, em dinheiro, é o equivalente ao carbono estocado na floresta de sua propriedade. Esse pagamento somente é feito a partir do monitoramento do projeto que é realizado anualmente para que seja comprovada a condição de conservação das florestas objeto do contrato. Percebeu-se nesse projeto que os contratos com os produtores têm um longo período de duração, 30 anos.

Assim, em termos gerais, este projeto, apesar de não ter uma legislação específica para a sua viabilidade, apresenta ambiente institucional plenamente definido, sendo capaz de diminuir as incertezas e estabelecer a base sustentável aos participantes dessa relação contratual. $\mathrm{Na}$ mesma linha, os arranjos institucionais que fazem parte do contrato permitem a implantação e o funcionamento do projeto com metodologia adequada, embora incipiente, sem comprometer o desenvolvimento e atingir os objetivos previamente traçados.

Já o Programa Suinocultura Sustentável Sadia (3S) funciona com a geração de crédito de carbono, baseado no mecanismo de desenvolvimento limpo MDL, no sistema de integração dos produtores rurais da empresa BR Foods com a instalação de biodigestores, em regime de comodato, para o aproveitamento de dejetos nas propriedades desses fornecedores, visando à diminuição e à ampliação do sequestro dos gases efeitos estufas da atmosfera, neste caso o gás metano. O mecanismo de desenvolvimento limpo tem sido apontado por sua forma de implementação individualista e, consequentemente, por ocasionar altos custos, além de limitar o número de atividades implantadas, o que justificou a utilização do Mecanismo de Desenvolvimento Limpo (PoA), que permite que um grupo de pequenos projetos de redução de emissões que apresentem a mesma metodologia sejam registrados como atividade do MDL única, em diferentes períodos e localidades.

Além da instalação dos biodigestores nas propriedades dos produtores integrados, prestadores dos serviços ambientais, que proporcionará a redução das emissões de gases de efeito estufa, gerando a comercialização de créditos de carbono, o programa definiu como objetivos a redução de impactos ambientais pelas práticas adotadas nas propriedades rurais e a promoção da sustentabilidade aos produtores de suínos.

Nesse projeto, a remuneração pelos serviços ambientais prestados pelos produtores será decorrente da comercialização dos serviços ambientais do carbono e seu pagamento ocorrerá 
após a liquidação dos investimentos realizados pela BR Foods. Todos os investimentos do projeto foram assumidos pela empresa, que utilizou recursos financeiros públicos, empréstimos do BNDES. A definição da remuneração percebida por cada um dos produtores será a proporção da redução dos gases efeito estufa em cada uma das propriedades, situação acompanhada pelos medidores instalados nos biodigestores. Ressalte-se, ainda, que esse pagamento somente é feito a partir do monitoramento da propriedade e da quantificação da redução dos gases efeito estufa em cada uma das propriedades.

O projeto apresenta um ambiente institucional plenamente formalizado, definido, com "regras do jogo" formais é capaz de reduzir as incertezas e estabelecer a base sustentável aos participantes do projeto por meio da relação contratual. Esse ambiente institucional tem os seus fundamentos na legislação que instituiu a Política Nacional sobre Mudança do Clima, nos contratos entre a empresa BR Foods e produtores rurais, que se encontram seguros nessa relação e estão agindo com ética no cumprimento dessas regras.

$\mathrm{Na}$ mesma linha, os arranjos institucionais que fazem parte desse projeto permitem a implantação e o funcionamento do projeto com metodologia adequada, embora incipiente, sem comprometer o desenvolvimento e atingir os objetivos previamente traçados. No arranjo institucional construído para o Projeto 3S, a ação e o envolvimento do Instituto Sadia, entidade sem fins lucrativos, foi de fundamental importância, pois representa pessoas movidas por questões de ética ou conscientização individual que se dispõem a apostar no desenvolvimento das políticas do meio ambiente. Diretamente envolvidos no projeto, estão o Instituto Sadia, a empresa BR Foods e o BNDES, ou seja, um número reduzido de entidades envolvidas: uma entidade não governamental e uma instituição pública financiadora.

Para a formatação e a construção do projeto foi realizado diagnóstico interno para avaliar as possibilidades existentes de desenvolvimento e implantação de projetos de carbono, o que permitiu a implantação de projetos piloto de instalação de biodigestores em propriedades próprias da empresa BR Foods. Esses projetos permitiram a experiência e o reconhecimento para a divulgação e a ampliação aos produtores integrados.

Assim, em termos gerais, este projeto, apesar de não ter uma legislação específica para a sua viabilidade, apresenta ambiente institucional plenamente definido, sendo capaz de diminuir as incertezas e estabelecer a base sustentável aos participantes dessa relação contratual. $\mathrm{Na}$ 
mesma linha, os arranjos institucionais que fazem parte do contrato, permitem a implantação e o funcionamento do projeto com metodologia adequada, embora incipiente, sem comprometer o desenvolvimento e atingir os objetivos previamente traçados.

Para finalizar os resultados e discussões dos projetos de captura de carbono, é preciso fazer a análise dos itens de estabilidade institucional. No que se refere à análise do grau de estabilidade institucional, os projetos de captura de carbono, a partir do modelo proposto, foram classificados segundo as categorias: estável, razoavelmente estável e instável. Essas categorias foram propostas levando em consideração o ambiente institucional, os arranjos institucionais, a participação da sociedade civil organizada e o tempo de duração do projeto, critérios justificados pelo fornecimento dos principais dados e informações suficientes para demonstrar o funcionamento do mercado dos serviços ambientais. No Quadro 14, é apresentada a classificação dos projetos segundo o grau de estabilidade.

Quadro 14 - Estabilidade institucional dos projetos de captura de carbono

\begin{tabular}{|l|c|c|c|}
\hline \multicolumn{2}{|c|}{ Projetos } & \multicolumn{3}{c|}{ CATEGORIAS } \\
\cline { 2 - 4 } & Estável & Razoavelmente Estável & Instável \\
\hline Carbono Seguro & & $\mathrm{X}$ & \\
\hline Programa Suinocultura Sustentável Sadia (3S) & & $\mathrm{X}$ & \\
\hline
\end{tabular}

O Programa Suinocultura Sustentável Sadia (3S) teve sua classificação como razoavelmente estável, pois possui pelos menos dois dos itens dessa categoria, ou seja, os arranjos institucionais (formais e informais) têm a participação de entidades públicas e privadas, e possui legislação específica, que, apesar de não ter sido criada para esse projeto pontual, é uma legislação ${ }^{121}$ adotada para todos os projetos que envolvem a comercialização de crédito de carbono. A entidade pública, o BNDES, financia o projeto com recurso que será pago com a venda dos créditos de carbono. Quanto ao tempo de duração, o projeto tem mais de cinco anos. O programa tem a participação de apenas uma entidade da sociedade civil sem fins lucrativos, o Instituto Sadia, o que impediu de ser considerado projeto estável na classificação por ora adotada.

Também projeto Carbono Seguro teve sua classificação como razoavelmente estável, pois possui pelo menos dois dos itens dessa categoria, ou seja, os arranjos institucionais (formais e informais) têm a participação de entidades públicas e privadas, apesar de a entidade pública

\footnotetext{
${ }^{121}$ Lei $n^{\circ} .12 .187$, (BRASIL, 2009).
} 
ser a Caixa Seguros e não especificamente o poder público estadual, municipal e/ou federal, possui duas entidades da sociedade civil, em seu arranjo institucional. Esse projeto não tem legislação específica para seu desenvolvimento e o seu tempo de duração tem apenas cinco anos, que foram dois itens que impediram sua classificação como projeto estável.

Por fim, nos projetos de produção de captura de carbono analisados, segundo as categorias estabelecidas, não houve nenhum projeto considerado estável e/ou instável.

\subsection{Resultados e discussões comparativas dos projetos de PSA produção de água e de carbono}

O mecanismo de Pagamento por Serviços Ambientais (PSA) vem ganhando reconhecimento não só de ambientalistas, técnicos e pesquisadores, mas também de gestores públicos, que já incluíram essa ferramenta em suas agendas ambientais e de gestão territorial. Isso porque o PSA vem se mostrando uma ferramenta efetiva de articulação local, de planejamento participativo, de distribuição de renda e de proteção ambiental. É nesse sentido que passa a ser relevante a análise dos projetos estudados empiricamente à luz da nova economia institucional.

Para que programas públicos de PSA possam ser realizados com efetividade, um dos aspectos fundamentais a serem considerados é o marco regulatório, que normalmente estabelece as diretrizes gerais da ação e os recursos financeiros que viabilizem sua implementação. Somente assim, com o ambiente institucional disciplinado por leis, decretos e outros instrumentos legais, é que será possível transferir dinheiro público, privado ou outros incentivos para um ente privado, por exemplo.

Por sua vez, os efeitos de PSA enfrentam permanentemente conflitos de interesses, de um lado, o proprietário, que busca na terra a exploração econômica que é fonte de recursos para sua sobrevivência (interesse privado) e, de outro lado, a sociedade, que busca a preservação dos ecossistemas em terras privadas (interesse difuso). Não há resposta aos problemas ambientais surgidos desses conflitos. Os instrumentos de comando e controle até então existentes não têm se revelado eficazes ou suficientes, pelo contrário, acabam dificultando a 
harmonização entre preservação e exploração. Assim, gera efeitos de preservação no longo prazo com efeitos não precificados.

A solução então é buscar a cooperação entre esses atores, diluindo a hegemonia dos interesses individuais para criar uma relação de interesses comuns, superando a concepção de que os recursos ambientais são inesgotáveis e fornecidos gratuitamente pela natureza. Ou, alternativamente, detectada a externalidade pela falha de mercado por não ter revelado eficazes ou suficientes a harmonização entre a preservação e exploração, e ainda, pela falta de precificação a longo prazo necessitaria então a regulação pelo Estado.

O PSA surge como um instrumento que tem capacidade de formar essa cooperação, estimulando o provedor de serviços ambientais a preservá-los, através de incentivos financeiras que compensem o custo da preservação, pagos pelo usuário dos serviços.

Os serviços ambientais ofertados pela natureza são de interesse de toda a sociedade, sendo justo que aquele que cuida da manutenção, preservação e recuperação dos ecossistemas seja compensado pelos custos dispendidos. O PSA tem a função de aproximar esses interesses, promovendo a sensibilização e cooperação entre provedor-recebedor e usuário- pagador.

No entanto, cabe esclarecer que o PSA não constitui um instrumento mercadológico, pois tem sua finalidade fincada no interesse público, que é a preservação dos serviços ambientais e a sua melhoria, diferentemente do interesse privado, que é típico do mercado. Os pagamentos são destinados a compensar as condutas daqueles que agem de forma ecologicamente correta e desejável com o meio ambiente, portanto, longe de constituir uma aquisição de parcela da natureza, mas tão somente para conservação desta. É um serviço inerente ao meio ambiente, somente podendo ser realizado pelo provedor dos serviços, por isso é considerado exclusivo, que beneficia toda a sociedade, dispensando a licitação, mesmo porque se trata de uma compensação que se dá entre o custo da conservação e o resultado que é a prestação do serviço ambiental.

Assim, o PSA se firma como uma importante ferramenta que vem complementar os atuais instrumentos do meio ambiente, mesmo porque é muito mais racional e econômico investir na preservação do que na reparação. 
Portanto não há como individualizar os mecanismos de funcionamento dos projetos de PSA analisados, quanto às informações colhidas relativas à efetiva articulação, o planejamento participativo, a distribuição de renda e a proteção ambiental que ocorrem de forma semelhante em cada projeto.

\subsubsection{Qual o ambiente institucional visualizado nos projetos?}

De modo mais geral, o papel e a razão de ser das instituições consistem em que elas podem reduzir a incerteza em face da racionalidade limitada dos agentes. Nesse ambiente econômico das organizações públicas ou privadas participantes dos projetos da água e do carbono, a incerteza está no conhecimento individual adequado de cada integrante desses projetos para fazer escolhas e tomar decisões.

De modo geral, como se percebe na descrição das regras de implementação projetos, o consumo e a produção de serviços de natureza ambiental criam externalidades ambientais, resultado de ações econômicas de produtores e consumidores sobre o meio ambiente. Essas externalidades exercem efeitos sobre outros agentes econômicos e não são incorporadas no sistema de preços.

As leis e instituições específicas em cada projeto foram elaboradas com a finalidade de abordar as externalidades negativas da atividade econômica sobre o meio ambiente, essencialmente, porque a oferta e a demanda não têm sido capazes de incluí-las na análise de equilíbrio do próprio mercado. Apesar da necessidade de quantificar os danos ambientais para reverter quadros de degradação e de suboferta de serviços ambientais, assim como para a adoção de medidas conservacionistas, há dificuldade em precificar as externalidades, porque não existe um valor monetário para os elementos naturais ligados ao processo produtivo, já que eles não estão envolvidos diretamente em transações mercantis.

Para incorporar os custos dos impactos da atividade agropecuária ao meio ambiente, os direitos de propriedade para as externalidades devem estar bem definidos. Uma vez definidos esses direitos de propriedade, é possível realizar negociação entre a parte afetada e a geradora de externalidades, de modo que são estabelecidos preços que auxiliam na alocação eficiente 
de recursos. Dessa maneira, a precificação das externalidades faz com que o meio ambiente deixe de ser um fornecedor de bens e serviços a custo zero, o que auxilia nas decisões econômicas e de preservação.

Nesse cenário, percebe-se que o pagamento por serviços ambientais (PSA) na agropecuária, que é base do presente estudo científico, emerge como instrumento econômico capaz de solucionar falhas de mercado relacionadas às externalidades. $\mathrm{O}$ fundamento é recompensar os produtores rurais integrantes dos projetos da água e do carbono que mantêm a qualidade dos serviços ambientais, criando uma estrutura de incentivos que melhore a rentabilidade das atividades de proteção e uso sustentável de recursos.

Dessa forma, o PSA em cada projeto trabalhado empiricamente baseia-se no princípio do protetor recebedor, que tende a ser mais estimulante ao produtor em comparação ao princípio do poluidor pagador. A ideia básica desses projetos é receber incentivos financeiros para preservar bens naturais que podem representar maiores vantagens do que arcar com os custos de reparação de danos ambientais posteriormente, como muito bem discriminados nos quadros números 11 e 13 respectivamente.

\subsubsection{Nos projetos o direito de propriedade é bem definido?}

O principal argumento de Coase (1960), em artigo seminal "The Problem of Social Cost", é que, se não houver custo de transação, então basta que os direitos de propriedade sejam bem definidos, que os agentes irão voluntariamente negociar de modo a levar os recursos a seu uso mais eficiente. A premissa é verdadeira, entretanto, se nas atividades de serviços ambientais os direitos de propriedade fossem bem definidos, e consequentemente, não houvesse os custos de transação, o uso eficiente dos recursos pela atividade econômica dos projetos deveria ser automaticamente atingido em sua plenitude.

Observa-se, nos projetos analisados, o aspecto da relevância econômica da definição do direito de propriedade. Essa definição é essencial para o desenvolvimento dos serviços ambientais, uma vez que se relaciona aos efeitos da atribuição de direitos sobre o comportamento dos produtores rurais, dos agentes econômicos e sobre o funcionamento dos mecanismos de mercado. Ou seja, sem a definição dos direitos de propriedade, há prejuízos 
nas transações econômicas com dificuldades de implementação e desenvolvimento de projetos mais abrangentes relativamente à água e ao carbono. Dessa maneira, somente havendo a definiç̧ão do direito de propriedade pode constituir objeto potencial de transações no mercado e, assim, contribuem para a criação e organização de mercados e redução de seus custos de transação, o que não se visualizou nos projetos de PSA analisados.

No tocante à transferibilidade do direito, percebe-se também a dificuldade de comercialização dos serviços ambientais, objetos dos PSA. Esta é condição adicional que lhe dá valor propriamente econômico, já que numa economia de mercado um dos elementos que mais importam na valoração de bens e ativos é o grau de fluidez com que estes podem circular, trocar de titularidade, e, portanto, a própria liquidez de seus eventuais estoques. Essa condição é fundamental para entender o papel da clara definição dos direitos na organização dos mercados e na redução de seus custos de transação, o que supõe enfocar precisamente esse momento em que os bens/direitos trocam de titularidade.

Portanto, a definição desses direitos nos projetos de PSA analisados é tida como fundamental para determinar os custos e benefícios associados ao uso dos recursos ambientais e à alocação destes entre indivíduos, estruturando os incentivos que determinam o comportamento econômico. Da mesma as instituições envolvidas nos PSA, que definem e alocam os direitos de propriedade, afetam as decisões e, por decorrência, o comportamento econômico e seus resultados. Essas instituições abrangem tanto as regras formais do ordenamento jurídico estatal - constituição, leis, decisões judiciais -, quanto os arranjos privados, as convenções e os costumes com vistas à alocação e ao uso do objeto do direito.

\subsection{3 É possível identificar fatores determinantes de custos de transação?}

Partindo-se da hipótese de que os custos de transação são aqueles que os agentes enfrentam toda vez que realizam trocas de direitos de propriedade, é possível identificar sua ocorrência nos projetos da água e do carbono.

Primeiro, pelo comportamento dos agentes ao enfrentar limitações à capacidade de acumular e processar as informações, assim como de transmiti-las no ambiente complexo e incerto dos 
serviços ambientais. Observa-se que nos contratos de prestação dos serviços ambientais ocorre a assimetria de informações do produtor rural e das organizações responsáveis pelos projetos, o que, sem dúvida, afeta o resultado final das atividades negociais.

Segundo, percebem-se atitudes oportunistas por parte das organizações encarregadas dos projetos da água e do carbono, principalmente, dadas a racionalidade limitada do produtor rural e a complexidade da própria legislação ambiental em contemplar todos os procedimentos alusivos à água e ao carbono. Isto é, impende que o produtor rural possa entender as particularidades das normas ambientais e avaliar com exatidão o valor da remuneração auferida pela prestação do serviço ambiental durante a vigência dos contratos.

Dessa maneira, mesmo a racionalidade limitada do produtor rural, a complexidade da legislação ambiental, a incerteza e o oportunismo não são suficientes para gerar os problemas no funcionamento do mercado da água e do carbono. O mercado existe e está em evolução.

A outra condição é individualizada nas transações que envolvem as especificidades dos ativos, ou seja, na prestação de serviço ambiental há limitação do número de agentes econômicos em realizar essa operação. Reduzem-se, susbstancialmente, os produtores rurais capazes de ofertar os serviços e os demandantes interessados em adquiri-los.

Dessa forma, pode-se afirmar que essas condições impõem dificuldades na contratação e na prestação dos serviços ambientais, principalmente, se ela será concretizada em data futura. Entretanto, observa-se nos projetos da água e do carbono que essas particularidades analisadas são fatores determinantes para a existência dos custos de transação, motivado pela racionalidade limitada do produtor rural e assimetria de informações, haja vista, a complexidade dos arranjos institucionais.

\subsubsection{Resultado comparativo dos projetos}

Percebe-se que os projetos da água e do carbono apresentam potencial para serem eficazes se conduzidos conforme planejado. Isso implica: monitoramento satisfatório a ponto de identificar falhas no cumprimento do acordo estabelecido; dedicação dos produtores que se propuseram a contribuir, principalmente na restauração da reserva legal; e empenho dos 
órgãos participantes do projeto para que cumpram sua parte no acordo. Talvez esse último seja o ponto mais difícil de ser cumprido.

São muitos os atores envolvidos e os planejamentos dos projetos apontam para um patamar de eficácia, pois, por meio das atividades propostas, a melhora ambiental poderia vir a acontecer e a capacidade de alcançar os objetivos propostos a custos menores do que outras soluções técnicas, mesmo que isso demande mais tempo, é um diferencial dos sistemas de PSA.

Identifica-se que os custos iniciais dos projetos analisados são elevados, entretanto, a tendência é diminuírem ao longo do tempo, e a expectativa do retorno ambiental tende só a aumentar com o avanço nos estágios sucessionais.

Induzir uma análise comparativa do custo de transação entre os projetos da água e do carbono significa aplicar o princípio básico dessa teoria e identificar os seus efeitos evolutivos. Ao tentar maximizar, respectivamente, sua utilidade e o resultado, os participantes desses projetos devem levar em conta os custos incorridos nas transações em que estiverem envolvidos. $\mathrm{Ou}$ seja, a inferência mais importante que se pode tirar é que há formas de organizar os arranjos institucionais que podem parecem ineficientes em um mundo sem a existência do custo de transação, mas que fazem sentido quando eles estão presentes.

O custo de transação podem variar de um projeto para outro. Isso porque a prestação dos serviços ambientais de cada um tem características próprias e apresentam complexidade, até na identificação da própria natureza. Ou seja, nesses mercados especiais com elevado grau de tecnologia ou nas suas transações de elevado valor, os custos de transação podem ser elevados.

Custos de transação muito elevado podem inviabilizar certos arranjos, a menos que, para funcionar, contem com o apoio de instituições mais complexas, do que apenas instalações, por exemplo, em que os compradores e vendedores se encontrem para realizar as operações comerciais. Em resumo, é preciso haver instituições e ambientes institucionais que reduzam os custos de transação nos mercados de água e carbono.

As instituições no mercado de água e carbono podem reduzir os custos de procura dos parceiros integrantes desses projetos, de acesso a informações, de negociação e da elaboração 
de contratos, assim como, de monitoramento do seu cumprimento. Nessa análise pode-se afirmar que o setor privado poderá ser capaz de desenvolver essas instituições, mas em outras é necessário a participação do Estado.

Assim, o papel das instituições no mercado da água e do carbono poderá reduzir os custos de transação, facilitando transação entre desconhecidos, balizando o que pode ser negociado e identificando as responsabilidades de cada um, permitindo a elaboração de contratos mais simples e fornecendo mecanismo que garantam o seu cumprimento.

Por sua vez, a teoria do custo de transação reforça a necessidade de pensar em mecanismo de coordenação para que os esforços individuais se revertam em benefícios coletivos, ou seja, de acordo com cada projeto (água e carbono) poderá haver aumento ou diminuição do custo de transação no processo de prestação de serviços ambientais, cultura e negociação.

Oliver Williansom (1985), o economista que mais se notabilizou por refinar a teoria coseana e estabelecer as funções da moderna teoria do custo de transação, estruturou a discussão das partes individual e coletivo em torno do oportunismo, que decorre dos diferentes sistemas e circunstâncias oferecidas. Aplicando-se aos projetos da água e carbono pode-se inferir o seguinte:

O primeiro fator pontencializador do oportunismo é a racionalidade limitado, isto é, as pessoas não são capazes de processar perfeitamente toda a informação disponível. No projeto de prestação de serviço ambiental da água em comparação com o carbono, verifica-se maior racionalidade limitada pelas mais variadas restrições cognitivas.

O segundo, a profunda incerteza. Quanto mais forem incertas as respostas aos questionamentos sobre o futuro dos projetos, tanto mais difícil será estabelecer as bases para ação humana. A incerteza poderá criar lacunas que um contrato nem sempre pode especificamente cobrir. Em termos de comparação pode-se afirmar que os dois contratos apresentam fator potencializado dos oportunismos, a incerteza.

O terceiro, é o fenômeno descrito por Oliver Williamson como especificidade de ativos. Ativos específicos são aqueles que têm um grande valor em aplicação específica, mas em outras não. No caso dos projetos em análise, esse conceito ajuda explicar uma série de 
comportamentos oportunistas que podem ocorrer na prestação dos serviços ambientais.

Os projetos apresentam equidade no acesso, pois há divulgação a todos os possíveis participantes, bem como não há barreiras ou requisitos exagerados que impeçam produtores rurais de formalizarem interesse em participar. A equidade na distribuição de custos e benefícios é percebida a partir do ponto em que os valores dos pagamentos são diferentes, de acordo com o grau de contribuição para a conservação da qualidade hídrica da região. Aqueles que recebem retornos diretos pelas atividades desenvolvidas pelos projetos recebem remuneração monetária menor. Portanto, o tratamento não é igual a todos os produtores rurais e aqueles que contribuem de maneira diferente recebem pagamentos diferentes.

Portanto, percebem-se possíveis limitações dos projetos pelo fato de que os pagamentos são estabelecidos de acordo com a modalidade adotada e sofrem alterações de acordo com o grau de prioridade da propriedade. Não há negociação desses valores com os proprietários. Isso pode resultar que nem sempre o valor acordado é o valor do ponto eficiente, podendo ocorrer que o valor pago seja superior ou inferior ao necessário para fazer com que o proprietário mude de atitude. Esse problema é decorrente da inflexibilização dos pagamentos. Além disso, ressalta-se que os custos de transação são elevados, uma vez que o número de instituições envolvidas é grande e, portanto, a remuneração do pessoal envolvido no projeto também o é.

Por fim, se comparadas as estabilidades institucionais dos projetos (Quadro 15), identificou-se que, de acordo com o critério ora proposto, os projetos razoavelmente estáveis estão em número maior que os projetos estáveis, o que se justifica pelo tempo de desenvolvimento desses projetos e pelos arranjos institucionais criados para garantir sua viabilidade. Da mesma forma, não foram encontrados nos projetos estudados projetos considerados instáveis, o que demonstra um sinal de preocupação com os aspectos de instabilidade que poderiam levar a projetos fracassados.

\begin{tabular}{|l|c|c|c|}
\hline \multirow{2}{|c|}{ Projetos } & \multicolumn{3}{c|}{ CATEGORIAS } \\
\cline { 2 - 4 } \multicolumn{1}{|c|}{} & Estável & Razoavelmente Estável & Instável \\
\hline Conservador das Águas & $\mathrm{X}$ & & \\
\hline Produtores de Água e Florestas - Guandu & & $\mathrm{X}$ & \\
\hline $\begin{array}{l}\text { Produtor de Água na Bacia Hidrográfica } \\
\text { Piracicaba/Capivari/Jundiaí/PCJ }\end{array}$ & & $\mathrm{X}$ & \\
\hline ProdutorES de Água & $\mathrm{X}$ & & \\
\hline Produtores de Água do Rio Camboriú & & $\mathrm{X}$ & \\
\hline Carbono Seguro & & $\mathrm{X}$ & \\
\hline $\begin{array}{l}\text { Programa Suinocultura Sustentável Sadia } \\
\text { (3S) }\end{array}$ & & $\mathrm{X}$ & \\
\hline
\end{tabular}




\section{CONSIDERAÇÕES FINAIS}

O PSA busca suavizar os impactos das obrigações legais de proprietários rurais que, amparados na incapacidade institucional de fiscalização, não cumprem total ou parcialmente as normas ambientais. Percebe-se que, caso a legislação esteja sendo respeitada, o PSA pode ser visto como um prêmio, uma recompensa pela conduta desejada.

Em geral, benefícios locais são maiores quando ações de conservação são preferidas a ações tecnológicas de remediação, pois aquelas são capazes de mudar a paisagem, alterar o microclima, aumentar a biodiversidade local, além de possibilitar que a população não passe por uma circunstância indesejada de crise para que depois seja adotada uma ação remediadora do problema. O PSA pode ter um caráter preventivo, assim como pode ser também remediador, este, contudo, demanda mais tempo para obter resultados.

A par dessa premissa, o PSA é um instrumento de conservação que vem sendo cada vez mais utilizado devido aos bons resultados já conquistados em casos pioneiros. Pode também ser um programa de caráter social, no sentido de ampliação da renda das famílias. A grande contribuição do PSA é a transformação de práticas desvantajosas no âmbito privado, mas desejadas socialmente, em vantagens individuais aos produtores, induzindo sua adoção e, portanto, melhorando a conservação ambiental.

Nos projetos estudados de negociação de serviços ambientais, atinentes à remuneração, tanto o poder público, quanto a inciativa privada, participam com recursos. O poder público com recursos oriundos da arrecadação tributária com fins específicos; à inciativa privada compete o suporte financeiro de acordo com a amplitude do problema ambiental, o que pode ser insustentável no longo prazo. Assim, os exemplos de pagamento por esses serviços ambientais com recursos públicos são escassos. São projetos isolados que dependem basicamente da política de cada município e/ou estado. Já aqueles realizados com recursos privados dependem de iniciativas individuais de grupos de pessoas dispostas a preservar o meio ambiente, mas que, pela escassez dos recursos financeiros, não conseguem estabelecer uma relação duradoura. 
Retomando a constatação de que os compradores do serviço ambiental são representados pelas pessoas estão envolvidas em questões ambientais, sejam entidades da sociedade civil, sejam pessoas movidas por questões de ética ou conscientização individual que se dispõem a apostar no desenvolvimento das políticas do meio ambiente; podem ser também empresas que buscam diferenciais no mercado por meio do envolvimento em projetos de PSA, com a intenção de promover seus produtos ou serviços com o selo de sustentabilidade. Também se identificou uma forte presença de entes federativos, neste caso, representados pelos municípios com financiamento de recursos para pagamento pelo serviço ambiental, ou pelo estado, ambos atuando como participantes dos projetos. Outra característica visualizada em todos os projetos de PSA estudados da água e de carbono foi a adoção do custo de oportunidade para a avaliação e o pagamento do serviço ambiental prestado pelos produtores.

A partir das informações qualitativas dos projetos, procurou-se identificar o grau de estabilidade dos projetos, que teve como premissa a elaboração de um modelo com categorias de projetos estáveis, razoavelmente estáveis e instáveis, que levaram em consideração o ambiente institucional, os arranjos institucionais, a participação da sociedade civil organizada e o tempo de duração do projeto. O resultado dessa análise é que os projetos razoavelmente estáveis estão em número maior que os estáveis, situação que se justifica pelo tempo de desenvolvimento dos projetos e dos arranjos institucionais criados para sua viabilidade. Não foram encontrados projetos considerados instáveis, o que vem demonstrar uma preocupação na formatação dos projetos com os aspectos do ambiente institucional e dos arranjos criados para seu desenvolvimento.

Conexa ao instituto de PSA, está a criação de mercados para a negociação desses serviços ambientais. $\mathrm{O}$ mercado poderá ser regulado por vários fatores, principalmente, pelo ambiente institucional, com edições de regras claras pelos órgãos reguladores, pelos incentivos para os agentes na organização de suas produções, e, ainda, pela correta definição dos direitos de propriedade.

Uma constatação foi a viabilidade das condições necessárias para a operação de mercado para os serviços ambientais, sob os preceitos definidos pela nova economia institucional, a começar pela definição dos direitos de propriedade. Ou seja, sem a definição dos direitos de propriedade, há prejuízos nas transações econômicas com dificuldades de implementação e 
desenvolvimento de projetos mais abrangentes relativamente à água e ao carbono. Percebe-se que há pouca definição do direito de propriedade para os projetos.

Sob a ótica do direito de propriedade - direito sobre os recursos ambientais -, procurou-se analisar como esse direito contribui para afetar o comportamento dos agentes econômicos e o desenvolvimento dos mercados de serviços ambientais. Haveria um direito absoluto sobre todos os aspectos? No que se refere ao recurso ambiental água, percebe-se que, nos projetos analisados, os direitos de propriedades não são absolutos, entretanto, os custos em proteger cada direito são crescentes no nível de segurança desejado, de modo que se torna inviável a obtenção do direito de propriedade perfeitamente seguro. No tocante à transferibilidade do direito, percebe-se também a dificuldade de comercialização dos serviços ambientais. A transferibilidade é condição adicional que lhe dá valor propriamente econômico, já que numa economia de mercado um dos elementos que mais importam na valoração de bens e ativos é o grau de fluidez com que estes podem circular, trocar de titularidade, e, portanto, a própria liquidez de seus eventuais estoques.

Seguindo a linha do construto, a firma é vista como um complexo de contratos e, se o comportamento otimizador dos agentes econômicos for mantido, pode-se explicar o arranjo produtivo via firma (forma hierárquica), via mercado ou via governança. É nesse sentido que a análise de Coase (1960) pode ser perfeitamente aplicável, quando os agentes e a sociedade estão preocupados com o desenvolvimento econômico sustentável, na idealização de um mercado para os serviços ambientais. Tais constatações encaixam-se na lógica da Nova Economia Institucional (NEI), que vem contemplar as instituições - regras editadas pelo poder regulatório -, os arranjos institucionais relacionados aos direitos de propriedade transacionados à condição da criação de mercado para os serviços ambientais.

Observa-se que a discussão sobre as normas que regulariam o PSA em âmbito nacional é pressionada cada vez mais pelo aumento do número de projetos nos estados e municípios, alguns dos quais já possuem legislação própria. Espera-se que a lei nacional estabeleça diretrizes fundamentais a serem observadas em normas estaduais e municipais, e que essas sejam as diretrizes específicas dos programas, especialmente as municipais, que são as mais próximas da realidade local e que possuem maior aplicabilidade, por respeitarem as peculiaridades regionais. 
Retomando o papel das instituições que tem implicações importantes em relação aos serviços ambientais, as leis que embasam a relação contratual dos projetos devem ser construídas objetivando a redução potencial dos conflitos induzindo os agentes econômicos a agirem de forma mais eficiente, sem, contudo, deixar de observar a relação das instituições formais e informais e os próprios costumes regionais, tão necessários ao desenvolvimento das atividades dos serviços ambientais.

Nos projetos analisados, percebem-se custos de transação elevados, principalmente, relacionados à busca de informações sobre os serviços ambientais, à negociação, à celebração dos contratos e os custos de monitoramento decorrentes dessa relação contratual, bem como à execução desses contratos em cumprir com os objetivos das organizações envolvidas e da própria sociedade.

Dessa forma, os custos de transação que os agentes enfrentam toda vez que recorrem ao mercado têm como unidade básica, principalmente, a análise do contrato. No que tange à matéria, a argumentação utilizada por Williamson (1985) baseia-se na ideia de transação entendida como a troca de bens e serviços entre pessoas ou através de fronteiras. Nessa perspectiva, a ênfase não se situa exclusivamente na tecnologia ou na função de produção, mas principalmente nos custos associados às transações e, portanto, às estruturas que governam essas transações: as organizações (hierarquia) ou o mercado (contratos). Assim, a opção por um ou outro modelo resultaria nos custos de transação associados à produção de determinado serviço ou bem. A complexidade das relações, a incerteza e as assimetrias de informação são fatores críticos que vão determinar os custos de transação e, naturalmente, a opção por uma ou outra forma de coordenação. Então, pode-se afirmar que a Nova Economia Institucional está localizada no ramo da eficiência dos contratos, decisivo para enfatizar os alinhamentos de incentivos e aqueles caracterizados pelas economias do custo de transação.

A linha argumentativa de Williamson (1985) é aplicável para o mercado organizado e os contratos são capazes de realizar as trocas de bens e serviços. Em sentido contrário, no mercado de serviços ambientais, em face da inexistência de mercado, as externalidades devem ser corrigidas pelo poder regulatório.

Assim, devido à inexistência de mercado e à deficiência das atividades reguladoras do Estado, a cooperação entre os agentes pode afastar toda e qualquer concepção do modelo de economia 
de mercado, que se estrutura na lógica inversa: a competição entre pessoas. Para Williansom (1985), na cooperação, o nível de especialização de ativos envolvidos no processo de produção é determinante para o processo de coordenação de atividades, no qual, necessariamente, o conceito do instituto está diretamente envolvido por meio de relações contratuais entre os atores econômicos.

Em outra linha de contribuição, sem a proposição de uma solução definitiva para a comercialização dos serviços ambientais, Coase (1974) trouxe uma importante contribuição, reforçando o importante papel do ambiente institucional, quando se trata do fornecimento de bens públicos. Ele sustentou sua visão não somente na ótica reguladora do Estado e dos mecanismos institucionais estatais, mas também considerou a possibilidade do fornecimento eficiente de bens públicos por parte de agentes econômicos privados, os quais podem abastecer o mercado desse tipo de bens, de forma eficiente, gerando benefícios privados, a depender do ambiente institucional, ou seja, o ambiente institucional é o principal fundamento do autor em relação a bens públicos. Essa linha pode coadunar-se com o mercado de serviços ambientais e com o aperfeiçoamento da sistemática dos projetos de PSA, a depender ainda de estudos mais aprofundados sobre o tema.

É fundamental deixar registrado, ao finalizar este estudo científico, que o mercado de serviços ambientais só funcionará de forma eficiente com a presença de instituições fortalecidas e pela redução ou inexistência dos custos de transação, a que todos os agentes estão sujeitos.

Como já registrado a criação de oportunidades em áreas específicas pode criar fortes incentivos econômicos para a manutenção de serviços ambientais, porém, em caso de má gestão, essas atividades podem degradar os próprios recursos nos quais estão baseadas. Finalmente, os mercados muitas vezes são incapazes de responder a questões de promoção de igualdade associadas à gestão das gerações presente e futuras, dado que algumas mudanças nos serviços ambientais são irreversíveis.

Necessária é a reflexão de que em futuro próximo poderá ocorrer a falta de agentes financeiros para dar continuidade e aperfeiçoamento às atividades de prestação de serviços ambientais, como já demonstrado em alguns projetos analisados.

Dessa forma, espera-se que a análise da literatura científica sobre o tema e a avaliação das 
experiências de PSA apresentadas nesta tese possam indicar elementos a serem aperfeiçoados para a melhoria de eficiência e equidade em projetos de pagamento por serviços ambientais.

Como sugestão para o aperfeiçoamento do presente estudo que ora se encerra sugerem-se investigações acerca dos avanços no método do cálculo do custo de oportunidade, que atualmente é o único critério adotado para remuneração de serviços ambientais; investigação junto ao usuário da água para saber sobre sua disposição em pagar pela remuneração pelos serviços ambientais prestados pelo produtor, quando da liquidação de sua conta de água, por meio de uma taxa não obrigatória. 


\section{REFERÊNCIAS}

ALCHIAN, Armen A. Some Economics of Property Rights. Il Politico 30, no. 4: 816-29. Reprinted in Armen A. Alchian, Economic Forces at Work. Indianapolis, Ind.: Liberty Press, 1965.

Norton, 1987.

Property rights. In The New Palgrave: A dictionary of economics. New York:

ALCHIAN, Armen A.; DEMSETZ, Harold. Production, Information information Costscosts, and Economic economic Organizationorganization. The American Economic Review. v. 62, n. 5, p. 777-795, Dec. 1972.

AHNERT, Fábio et al. Projeto produtores de água. In: GLEHN, Helena Carrascosa Von, PAGIOLA Stefano, TAFFARELLO, Denise (Org.). Experiências de pagamento por serviços ambientais no Brasil. São Paulo: Secretaria do Meio Ambiente: 2012. Cap. 17, p. 271-288.

ALLEN, Douglas W. What are transaction costs? Research in law and economics. n. 14, p. $1-18,1991$.

AGÊNCIA NACIONAL DE ÁGUAS. A Implementação da Cobrança pelo Uso de Recursos Hídricos e Agência de Águas das Bacias dos Rios Piracicaba, Capivari e Jundiaí. Brasília: ANA, SAG, 2007. 112 p.

ANUATTI NETO, Francisco. Introdução à microeconomia. In: PINHO, Diva Benevides; VASCONCELLOS, Marco Antonio S. de; TONETO JR., Rudnei (Org.). Manual de economia. 6. ed. São Paulo: Saraiva, 2011. Cap. 10, p. $246-263$.

ARAÚJO SÁ, J. A. C.; CAMPOS, L. R. O Direito e a gestão das águas. In: CAMPOS, J. N. B.; STUDART, T. M. C. Gestão de águas: princípios e práticas. Porto Alegre: Associação Brasileira de Recursos Hídricos, 2001

AUGUSTO, Ricardo et al. Produtor de água na bacia hidrográfica Piracicaba/Capivari/Jundiaí. In: GLEHN, Helena Carrascosa Von; PAGIOLA, Stefano; TAFFARELLO, Denise (Org.). Experiências de pagamento por serviços ambientais no Brasil. São Paulo: Secretaria do Meio Ambiente, 2012. Cap. 7, p. 99-113.

AZEVEDO, P. F. Comercialização e produtos agropecuários. In: BATALHA, M. O. et al (Coord.). Gestão agroindustrial. São Paulo: Atlas, 2001.

BALNEARIO CAMBORIÚ, Lei n ${ }^{\circ}$ 2.498, de 31 de outubro de 2005. Cria a Empresa Municipal de Saneamento de Balneário Camboriú, como Entidade Autárquica de Direito Público da Administração Indireta e dá outras providências. Diário Oficial do Estado de Santa Catarina, Balneário Camboriú, SC, 31 out. 2005. Disponível em: $<$ http://cambc.sc.gov.br/leis/texto/2498/L>. Acesso em: 20 fev. 2014. 
BALNEARIO CAMBORIÚ, Lei n ${ }^{\circ}$ 3.026, de 26 de novembro de 2009. Cria o Projeto Produtor de Água, autoriza a empresa Municipal de Água e Saneamento (EMASA) a prestar apoio financeiro aos proprietários rurais e dá outras providências. Diário do Estado de Santa Catarina, Balneário Camboriú, SC, 26 nov. 2009. Disponível em: $<$ https://www.leismunicipais.com.br/a/sc/b/balneario-camboriu/leiordinaria/2009/302/3026/lei-ordinaria-n-3026-2009-cria-o-projeto-produtor-de-agua-autorizaa-empresa-municipal-de-agua-e-saneamento-emasa-a-prestar-apoio-financeiro-aosproprietarios-rurais-e-da-outras-providencias-2011-05-16.html>. Acesso em: 20 fev. 2014.

BALNEARIO CAMBORIÚ, Decreto $\mathrm{n}^{\circ}$ 6.121, de 16 de maio de 2011. Regulamenta a Lei $\mathrm{n}^{\circ}$. 3026 de 26 de novembro de 2009, que versa sobre a criação do Projeto Produtor de Água, Autoriza a Empresa Municipal de Água e Sanemaneto EMA a prestar apoio financeiro aos proprietários rurais e dá outras providências. Diário Oficial do Estado de Santa Catarina, Balneário Camboriú, $\mathrm{SC}, 16$ mai. 2009. Disponível em: < https://www.leismunicipais.com.br/a/sc/b/balneariocamboriu/decreto/2011/612/6121/decreto-n-6121-2011-regulamenta-a-lei-n-3026-de-26-denovembro-de-2009-que-versa-sobre-a-criacao-do-projeto-produtor-de-agua-autoriza-aempresa-municipal-de-agua-e-saneamento-emasa-a-prestar-apoio-financeiro-aosproprietarios-rurais-e-da-outras-providencias.html>. Acesso em: 20 fev. 2014.

BIODIESEL.BR.COM. Disponível em: < http://www.biodieselbr.com> . Acesso em 20 jul. 2014

BITTAR, R. Cresce interesse pelo mercado de crédito de carbono. Valor Econômico. São Paulo, P. A5, 05/11/2004.

BOLSA DE MERCADORIAS E FUTURO. Disponível em: $<$ http://www.bmfbovespa.com.br/home.aspx?idioma=pt-br>. Acesso em: 06 jan. 2013.

BONI, Valdete; QUARESMA, Sílvia Jurema. Aprendendo a entrevistar: como fazer um entrevista em Ciências Sociais. Em tese, Florianópolis. V. 2, n. 1, p. 68-80, 2005.

BORN, R.; TALOCCHI, S. Payament for environmental services: Brazil. Relatório elaborado como parte do projeto Payament for Environmental Services in Americas. 2002.

BOYD, Harper; WESTFALL, Ralph; STASCH, stanley. Marketing research: text and cases. Illinois: Richard D. Irwin, 1985.

BRAGA, Eugênio Carlos Ferreira. Entre fatos e discursos: sobre o debate em torno da convergência técnico-metodológica. Revista Brasileira de Informação Bibliográfica em Ciências Sociais (BIB), São Paulo. n. 64, 2007.

BRACER, C. et al. Organization and governance for fostering pro-poor compensation for environmental services. Nairobi, Kenya: World Agroforestry Centre, 2007.

BRASIL, Lei $\mathrm{n}^{\circ}$ 6.938, de 31 de agosto de 1981. Dispõe sobre a Política Nacional do Meio Ambiente, seus fins e mecanismos de formulação e aplicação, e dá outras providências. Diário da República Federativa do Brasil, Brasília, DF, 02 set. 1981. Disponível em: $<$ http://www.planalto.gov.br/ccivil_03/Leis/L6938.htm>. Acesso em: 30 nov. 2011. 
Constituição da República Federativa do Brasil de 1988. 05 de outubro de 1988. Diário da República Federativa do Brasil, Brasília, DF, 05 out. 1988. Disponível em: $<$ http://www.planalto.gov.br/ccivil_03/Constituicao/Constituicao.htm $>$. Acesso em: 3 dez. 2011.

Lei $n^{\circ}$ 9.433, de 08 de janeiro de 1997. Institui a Política Nacional de Recursos Hídricos, cria o Sistema Nacional de Gerenciamento de Recursos Hídricos, regulamenta o inciso XIX do art. 21 da Constituição Federal, e altera o art. $1^{\circ}$ da Lei $\mathrm{n}^{\circ} 8.001$, de 13 de março de 1990, que modificou a Lei $\mathrm{n}^{\circ} 7.990$, de 28 de dezembro de 1989. República Federativa do Brasil, Brasília, DF, 08 jan. 1997. Disponível em: $<$ http://www.planalto.gov.br/ccivil_03/leis/L9433.htm>. Acesso em: 07 jan. 2014.

. Lei $\mathrm{n}^{\mathrm{o}}$ 10.406, de 10 de janeiro de 2002. Institui o Código Civil. República Federativa do Brasil, Brasília, DF, 10 jan. 2002. Disponível em: <http://www.planalto.gov.br/ccivil_03/Leis/2002/L10406.htm>. Acesso em: 12 nov. 2012.

Lei ${ }^{0} 10.881$, de 09 de junho de 2004. Dispõe sobre os contratos de gestão ente Agência Nacional de Águas e entidades delegatárias das funções de Agências de Água relativas à gestão de recursos hídricos de domínio da União e dá outras providências. República Federativa do Brasil, Brasília, DF, 09 jun. 2004. Disponível em: $<$ http://www.planalto.gov.br/ccivil_03/_ato2004-2006/2004/lei/110.881.htm>. Acesso em: 30 jan. 2014.

. Lei $n^{\circ} 11.326$, de 24 de junho de 2006. Estabelece as diretrizes para formulação da Política Nacional da Agricultura Familiar e Empreendimentos Familiares Rurais. República Federativa do Brasil, Brasília, DF, 26 jun. 2006. Disponível em: < http://www.planalto.gov.br/ccivil_03/_ato2004-2006/2006/lei/111326.htm>. Acesso em: 06 mar. 2014.

Lei $\mathrm{n}^{\mathrm{o}}$ 12.187, de 29 de dezembro de 2009. Institui a Política Nacional sobre Mudança do Clima - PNMC e dá outras providências. República Federativa do Brasil, Brasília, DF, 30 dez. 2009. Disponível em: <http://www.planalto.gov.br/ccivil_03/_Ato20072010/2009/Lei/L12187.htm>. Acesso em: 06 dez. 2011.

Lei $\mathrm{n}^{\mathrm{0}} 12.651$, de 25 de maio de 2012. Dispõe sobre a proteção da vegetação nativa; altera as Leis $\mathrm{n}^{\text {os }}$ 6.938, de 31 de agosto de 1981, 9.393, de 19 de dezembro de 1996, e 11.428, de 22 de dezembro de 2006; revoga as Leis $n^{\text {os }} 4.771$, de 15 de setembro de 1965, e 7.754, de 14 de abril de 1989, e a Medida Provisória $\mathrm{n}^{\mathrm{o}}$ 2.166-67, de 24 de agosto de 2001; e dá outras providências. República Federativa do Brasil, Brasília, DF, 25 mai. 2012. Disponível em: < http://www.planalto.gov.br/ccivil_03/_ato2011-2014/2012/lei/112651.htm>. Acesso em: 06 mar. 2013.

SÃO PAULO. Lei $\mathrm{n}^{\mathrm{o}} 13.798$, de 09 de novembro de 2009. Institui a política estadual de mudanças climáticas PEMC. Diário Oficial do Estado de São Paulo, São Paulo, SP, 09 nov. 2009. Disponível em: <http://www.al.sp.gov.br/repositorio/legislacao/lei/2009/lei13798-09.11.2009.html>. Acesso em: 30 jan. 2014.

SÃO PAULO. Decreto $n^{\circ} 55.947$, de 24 de junho de 2010. Regulamenta a Lei $\mathrm{n}^{\circ} .13 .798$, de 9 de novembro de 2009, que dispõe sobre a política estadual de mudanças climáticas. Diário Oficial do Estado de São Paulo, São Paulo, SP, 09 nov. 2009. Disponível em: < 
http://www.al.sp.gov.br/repositorio/legislacao/decreto/2010/decreto-55947-24.06.2010.html>. Acesso em: 30 jan. 2014.

BRF RELATÓRIO ANUAL DE SUSTENTABILIDADE, 2013. Disponível em: $<$ http://www.brasilfoods.com/ri/siteri/web/arquivos/BRF\%20RA\%20PT\%20140609.pdf>. Acesso em 30 abr. 2014

BUONOCORE, Vincenzo. Limpresa. In: Torino: G. Giappichelli, 2002. v.1, t. 2.1. . (Coord.). Trattato di Diritto Commerciale.

CAMPOS, C.C et al. Mercado brasileiro de reduções de emissões. Disponível em: $<$ http://www.desenvolvimento.gov.br/arquivo/ascom/imprensa/20041202MBREFinal.pdf $>$. Acesso em: 1 maio 2014.

CACHO, O.; MARSHALL, G. R.; MILNE, M. Transaction and abatement costs of carbonsink projects in developing countries. Environment and Development Economics. v. 20, p. 597-614, 2005.

CAMPOMAR, Marcos Cortez. Do uso de estudo de caso em pesquisas para dissertações e teses em Administração. Revista de Administração, São Paulo. V. 26, n. 3, p. 95-97, julho/agosto/setembro 1991.

CARMINES, E. G.; ZELLER, R. A. Reliability and validity assesment. Beverly Hills, CA: Sage Publications, 1988. Séries: Quantitative Applications in Social Sciences, v. 17, 1988.

CHAGAS, Andre Luiz Squarize. Introdução à microeconomia. In: PINHO, Diva Benevides; VASCONCELlOS, Marco Antonio S. de; TONETO JR., Rudnei (Org.). Manual de Economia. 6. ed. São Paulo: Saraiva, 2011. Cap. 12, p. 283-291.

CHEUNG, Steven N. S. A Theory of share tenancy. Chicago: University of Chicago Press, 1969.

COASE, R. H. The nature of the firm. Economica. v. 4, n. 16, p. 386-405, Nov. 1937. Reprinted in COASE, R. H. The firm, the market and law. Chicago: University of Chicago Press, 1988.

. The problem of social cost. Journal of Law and Economics, Chicago. v. 3, n. 4, p. $1-44$, October 1960.

. The lighthouse in Economics. Journal of Law and Economics, Chicago. V. 17, n. 2, p. 357-376, 1974.

. The Institucional Structure of Production. Nobel Lecture. The Nobel Foundation, 1991.

COHEN, Morris; NAGEL, Enerst. Introdución a la lógica y al método científico. 2. ed. Buenos Aires: Amarrortu, 1971. 2v.

COOPER, Donald R. et al. Métodos de pesquisa em administração. Tradução Luciana de Oliveira Rocha. 7. ed. Porto Alegre: Bookman, 2003. 
CONSTANZA, R. D. et al. The value of world's ecosystem services and natural capital. Nature. v. 387, p. 253-260, 1997.

CORTEZ, Benedito Arlindo et al. Conservador das águas. Minas Gerais: Departamento Meio Ambiente Extrema-Minas Gerais, 2010.

DAILY, Gretchen C. (Ed.). Nature's services: societal dependence on natural eosystems. Washington, DC: Island Press, 1997. 392 p.

DAILY, Gretchen C., ELLISON, Katharine. The new economy of nature: the quest to make conservation profitable. Washington, DC: Island Press, 2002.

DEMSETZ, H. Towards a theory of property rights. American Economic Review, Pittsburgh, PA. v. 57, n. 2, p. 347-373, May 1967.

DE PLÁCIDO e Silva. Vocabulário jurídico. 25. ed. São Paulo: Forense, 2004.

DUARTE, Rosália. Entrevista em pesquisas qualitativas. Educar em Revista, Curitiba. n. 24, p. 213-225, 2004.

EATON, B. Curtis; EATON, Diane F. Microeconomia. Tradução de Cecília C. Bartalotti da. 3. ed. São Paulo: Saraiva, 1999.

ECOSYSTEM ENVIRONMENTAL ASSESSMENT. Disponível em: $<$ http://www.milleniumassessment.org>. Acesso em: 15 jan. 2013.

EGGERTSSON, Thráinn. Economic Behavior and Institutions. Cambridge: Cambridge Unsiversity Press, 1990.

ENVIRONMENT \& SOCIETY PORTAL. Disponível em: $<$ http://www.environmentandsociety.org/exhibitions/silent-spring/overview $>$. Acesso em: 31 maio 2013.

ESPÍRITO SANTO, Lei ${ }^{\circ}$ 8.995, de 22 de setembro de 2008. Institui o Programa de Pagamento por Serviços Ambientais - PSA e dá outras providencias. Diário do Estado do Espírito Santos, Vitória, ES, 22 set. 2008. Disponível em: $<$ https://www.rcambiental.com.br/atos/ver/Lei-ES-8995-2008 >. Acesso em: 20 fev. 2014.

ESPÍRITO SANTO, Decreto $\mathrm{n}^{\circ}$. $2.168 \mathrm{R}$, de 09 de dezembro de 2008. Aprova o regulamento da Lei $n^{0} .8 .995$ de 22 de setembro de 2008 de dispõe sobre o Programa de Pagamento por Serviços Ambientais - PSA. Diário do Estado do Espírito Santo, Vitória, ES, 08 dez. 2008. Disponível em: < http://www.meioambiente.es.gov.br/default.asp>. Acesso em: 20 fev. 2014.

ESPÍRITO SANTO, Lei ${ }^{\circ}$ 9.864, de 26 de junho de 2012. Dispõe sobre a reformulação do Programa de Pagamento por Serviços Ambientais - PSA no Estado, instituído pela Lei $\mathrm{n}^{\circ}$. 8.995, e dá outras providencias. Diário do Estado do Espírito Santos, Vitória, ES, 22 set. 2008. Disponível em: <https://www.rcambiental.com.br/atos/ver/Lei-ES-9864-2012 >. Acesso em: 20 fev. 2014. 
EXTREMA, Lei $\mathrm{n}^{\mathrm{o}} 2.100$, de 21 de dezembro de 2005. Cria o Projeto Conservador das Águas, autoriza o executivo a prestar apoio financeiro aos proprietários rurais e dá outras providências. Diário do Estado de Minas Gerais, Estrema, MG, 21 dez. 2005. Disponível em: <http://www.comitepcj.sp.gov.br/download/Lei-2100-05_Extrema-MG.pdf $>$. Acesso em: 20 jun. 2013.

EXTREMA, Decreto $n^{\circ} 1.703$, de 06 de abril de 2006. Regulamenta a Lei $\mathrm{n}^{\circ} .2 .100$, de 2005 que cria o Conservador das Águas, autoriza o executivo a prestar apoio financeiro aos proprietários rurais e dá outras providências. Diário do Estado de Minas Gerais, Estrema, MG, 06 abr. 2006. Disponível em: < http://www.comitepcj.sp.gov.br/download/Decreto1703-06_Extrema-MG.pdf>. Acesso em: 20 jun. 2013.

EXTREMA, Decreto $n^{\circ} 2.409$, de 29 de dezembro de 2010. Regulamenta a Lei $\mathrm{n}^{\circ} .2 .100$, de 2005 que cria o Conservador das Águas, autoriza o executivo a prestar apoio financeiro aos proprietários rurais e dá outras providências. Diário do Estado de Minas Gerais, Extrema, MG, 29 dez. 2010. Disponível em: < http://extrema.mg.gov.br/conservadordasaguas/Decreto2409.pdf>. Acesso em: 20 jun. 2013.

FARINA, E. M. Q. Competitividade e coordenação dos sistemas agroindustriais: a base conceitual. In: JANK, Marcos S. et al. Agribusiness do leite no Brasil. São Paulo: IPEA, 1999.

FEARNSIDE, P. M. Environmental services as a strategy for sustainable development in rural Amazonia. Ecological Economics, Amsterdam.v. 20, n. 1, p. 53-70, 1997.

FIORILlO, Celso Antônio Pacheco. Curso de direito ambiental brasileiro. São Paulo: Saraiva, 2008.

FRANK, Robert H.; BERNANKE, Ben S. Princípios de economia. Tradução de Heloisa Fontoura e Monica Stefani. Porto Alegre: AMGH, 2012.

FULTON, M. E. The future of Canadian agricultural cooperatives: a property rights approach. American Journal of Agricultural Economics. v. 77, p. 1144-1152, 1995.

FUNDAÇÃO AMAZONAS SUSTENTÁVEL. Disponível em: < amazonas.org/programa-bolsa-floresta/>. Acesso em: 11 ago. 2012.

GARCIA, Maria da Glória F. P. D. O lugar do direito na proteção do ambiente. Coimbra: Almedina, 2007.

GIL, Antonio Carlos. Como elaborar projetos de pesquisa. 4. ed. São Paulo: Atlas, 2002.

HEAL, G. Nature and the marketplace: capturing the value of ecosystem services. Washington, DC: Island Press, 2000. 203 p.

HARDIN, G. Tragedy of the commons. Science. v. 162, n. 3859, p. 1243-1248, December 1968.

HARDNER, J.; RICE, R. Rethinking green consumerism. Scientific American. v. 286, p. 8995, May 2002. 
HAYEK, F.A. The Road to Serfdom. 1944. Traduzido por Anna Maria Capovilla, José Ítalo Stelle e Liane de Morais Ribeiro. O Caminho da Servidão. São Paulo : Instituto Ludwig von Mises Brasil, 2010. Disponível em: $<$ http://www.mises.org.br/files/literature/O\%20CAMINHO\%20DA\%20SERVID\%C3\%83O \%20-\%20WEB.pdf>. Acesso em 22 jul. 2014.

HOESKSTRA et al. Manual de Avaliação da Pegada Hídrica. 2011. Disponível em: $<$ http://www.waterfootprint.org/downloads/ManualDeAvaliacaoDaPegadaHidrica.pdf $>$.

Acesso em 20 jul.2014

HUBBARD, R. Glenn; O'BRIEN, Anthony Patrick. Introdução à Economia. 2. ed. Porto Alegre: Bookman , 2010.

IBGE, 2010 http://www.cidades.ibge.gov.br/painel/painel.php?lang=\&codmun=420200\&search=|balneari o-camboriu>. Acesso em: 20 abr. 2014.

INCRA. 2002. Disponível em: <http://www.incra.gov.br>. Acesso em 20 fev. 2014.

INSTITUTO DO CARBONO BRASIL. Disponível em: $<$ http://www.institutocarbonobrasil.org.br/mercado_de_carbono/protocolo_de_quioto $>$. Acesso em: 15 jan. 2013.

INSTITUTO DE PESQUISA AMBIENTAL DA AMAZONIA. Disponível em: $<$ http://www.ipam.org.br>. Acesso em: 15 out. 2012.

INSTITUTO DE PESQUISA AMBIENTAL DA AMAZONIA. 2014. Disponível em: $<$ http://www.ipam.org.br>. Acesso em: 15 out. 2012.

JACOBS, M. La economía verde: medio ambiente, desarrollo sostenible y la política del futuro. 2. ed. Barcelona: Icaria, 1997.

KAUL, Inge; GRUNBERG, Isabelle; STERN, A. Definindo bens públicos globais. In: . (Org.). Bens públicos globais. Rio de Janeiro: Record, 2012. Cap. 1, p. 41-58.

KERLINGER, Fred Nichols. Metodologia da pesquisa em ciências sociais: um tratamento conceitual. São Paulo: EPU, 1980.

KLEMZ, Cláudio, et al. Projeto de Água do Rio Camboriú. In: GLEHN, Helena Carrascosa Von, PAGIOLA Stefano, TAFFARELlO, Denise (Org.). Experiências de pagamento por serviços ambientais no Brasil. São Paulo: Secretaria do Meio Ambiente: 2012. Cap. 8, p. 115-130.

LANDELL-MILLS, Natasha; PORRAS, Ina.T. Silver bullet or fool's gold? A global review of markets for forest environmental services and their impact on the poor. London: IIED Catalogue, 2002.

LAKATOS, Eva Maria; MARCONI, Marina de Andrade. Metodologia científica. 5. -ed. São Paulo: Atlas, 2009. 
LANNA, A. E. L. Cobrança e mercados de água como instrumentos de gerenciamento dos recursos hídricos no semiárido do Nordeste brasileiro. In: SIMPÓSIO DE RECURSOS HÍDRICOS DO NORDESTE, 2., Fortaleza. Anais... Ceará, 1994.

LAVILLE, Christian; DIONNE, Jean. A construção do saber: manual de metodologia da pesquisa em ciências humanas. Belo Horizonte: UFMG, 1999.

MACDONALD, D. H.; CONDOR, J.; MORRISON, M. Economic instrumens for managing water quality in New Zeland. Final Report for NZ Ministry for the Environment. CSIRO Land Water, New Zealand, 2004.

MILARÉ, Édis. Direito do ambiente, a gestão ambiental em foco, doutrina, jurisprudência e glossário. 5. ed. São Paulo: Editora Revista dos Tribunais, 2007.

MIRANDA, Silvia; OLIVA, Felipe. Definição de bens e serviços ambientais (EGs) é pauta da Rodada de Doha. Disponível em: $<$ http://www.cepea.esalq.usp.br/pdf/Cepea_Internacional_out05.pdf $>$. Acesso em: 9 dez. 2011.

MINISTERIO DA CIÊNCIA TECNOLOGIA E INOVAÇÃO. Disponível em: $<$ http://www.mct.gov.br/upd_blob/0210/210584.pdf>. Acesso em: 28 fev. 2013

MONTEIRO, G. F. A. ; ZYLBERSZTAJN, Decio. Economic governance of property rights: a comparative analysis on the collection of royalities in genetically modified soybean seeds. In: ANNUAL CONFERENCE OF THE INTERNATIONAL SOCIETY FOR NEW INSTITUTIONAL ECONOMICS - ISNIE, 14., 2011, Scotland. Proceedings... Scotland, 2011. v. 1.

MONTORO FILHO, André Franco. Teoria elementar do funcionamento do mercado. In: PINHO, Diva Benevides; VASCONCELLOS, Marco Antonio S. de; TONETO JR., Rudnei (Org.). Manual de Economia. 6. ed. São Paulo: Saraiva, 2011. Cap. 5, p. 115 - 145.

MUELLER, Charles C. Os economistas e as relações entre o sistema econômico e o meio ambiente. Brasília: UNB/FINATEC, 2007

NORTH, D. C. Institutions, institutional change and economic performance. Cambridge: Cambridge University Press, 1990. 159p.

NORTH, D. C. Institutions. Journal of Economic Perspective. v. 5, n. 1, p. 97-112, Winter, 1991.

NORTH, Douglas. Institutions, and Economic Performance, in Maki, Uskali; Gustafsson, Bo; Knudsen, Cristian (ed.) Rationality, Institutions and Economic Mehodology. Londres e Nova Uorque: Routledge, 242-261.

OSTROM, Elinor, 1990. Governing the commons: the evolution of institutions for collective action. Cambridge: Cambridge University Press, 1990. 280p.

,2010. Beyond Markets and States: polycentriz governance of complex economic system. American Economic Review 100, 2010. 
PADOVEZI, Aurélio, et al. Produtor de Água na Bacia Hidrogáfica Piracicaba/Capivari/Jundiaí. In: GLEHN, Helena Carrascosa Von, PAGIOLA Stefano, TAFFARELLO, Denise (Org.). Experiências de pagamento por serviços ambientais no Brasil. São Paulo: Secretaria do Meio Ambiente: 2012. Cap. 7, p. 99-113.

PARKIN, Michel. O problema econômico. In: Economia. 8. ed. Tradução de Cristina Yamagami. São Paulo: Pearson, 2009. Cap. 2, p. $29-53$.

PAGIOLA, S. et al. Paying for biodiversity conservation services - experience in Colombia, Costa Rica, and Nicarágua. Mountain Research and Development. v. 25, n. 3, p. 206-211, 2005.

PAGIOLA, S.; PLATAIS, G. Payments for environmental services: from theory to pratice. Washington: World Bank, 2007.

PEREIRA, Paulo Henrique. Projeto Conservador das Águas - Extrema. In: GLEHN, Helena Carrascosa Von, PAGIOLA Stefano, TAFFARELLO, Denise (Org.). Experiências de pagamento por serviços ambientais no Brasil. São Paulo: Secretaria do Meio Ambiente: 2012. Cap. 2, p. 29-40.

PEREIRA, Gilberto S. et al. Produtores de Água - Guandu. In: GLEHN, Helena Carrascosa Von, PAGIOLA Stefano, TAFFARELLO, Denise (Org.). Experiências de pagamento por serviços ambientais no Brasil. São Paulo: Secretaria do Meio Ambiente: 2012. Cap. 5, p. 6783.

PERMAN, R. et al. Natural resource and environmental Economics. London: Longman, 1996. Caps. 8 e 9.

PINDYCK, Robert S.; RUBINFELD, Daniel L. Microeconomia. Tradução Eleutério Prado. 6. ed. São Paulo: Pearson Education do Brasil, 2005.

PINHEIRO, Armando Castelar; SADDI, Jairo. Direito, economia e mercado. Rio de Janeiro: Elsevier, 2005.

PINTO, Erika et al. Cartilha: Perguntas e Respostas Sobre Aquecimento Global. 4 ed. Belém: Instituto de Pesquisa Ambiental da Amazônia, 2009.

PROGRAMA DAS NAÇOES UNIDAS PARA O MEIO AMBIENTE (PNUMA). Disponível em: <http://www.pnuma.org.br/publicacoes.php>. Acesso em: 11 ago. 2012.

PROGRAMA PRODUTOR DE ÁGUA. Disponível em: <http://produtoragua.ana.gov.br>. Acesso em: 07 dez. 2012.

RESOLUÇÃO No 42 DO COMITE GUANDU, de 18 de dezembro de 2009. Disponível em: $<$ https:// www.comiteguandu.org.br/conteudo/resolucao42>. Acesso: em jan. 2014.

RESOLUÇÃO No 85 DO COMITE GUANDU, de 12 de setembro de 2012. Disponível em: $<$ https:// www.comiteguandu.org.br/conteudo/resolucao85>. Acesso: em jan. 2014. 
ROCHA, M. T. Aquecimento global e o mercado de carbono: uma aplicação do modelo Cert. Piracicaba, 2003. Tese (Doutorado) - Escola Superior de Agricultura "Luiz de Queiroz" da Universidade de São Paulo.

RIO CLARO, Lei no 514, de 29 de dezembro de 2010. Cria o Projeto Produtor de Águas e Florestas, autoriza o executivo a prestar apoio financeiro aos proprietários de RPPN e dá outras providências. Diário do Estado de Rio de Janeiro, Rio Claro, RJ, 29 dez. 2010. Disponível em: < http://rioclaro.rj.gov.br/Leis/2010/Lei\%20414.pdf>. Acesso em: 20 jun. 2013.

RIO CLARO, Decreto no 931, de 01 de julho de 2011. Regulamenta a Lei Municipal $n^{\circ} .514$, de 29 de dezembro de 2010 e dá outras providências. Diário do Estado de Rio de Janeiro,

Rio Claro, RJ, 01 jul. 2011. Disponível em: < http://rioclaro.rj.gov.br/Decretos/2011/Decreto\%20931.pdf>. Acesso em: 20 jun. 2013.

ROSSATO; Paulo, BELLAVER, Pauline. Economia Verde: Mecanismo de Desenvolvimento Limpo (MDL) e Redução de emissões por Desmatamento e Degradação (REDD). Senado Federal Audiência Pública. Disponível em: < http://www.senado.leg.br/comissoes/cma/ap/AP20110630_Paulo_Sadia.pdf $>$. Acesso em 30 nov. 2013.

SÁ, et al. Programa Carbono Seguro. In: GLEHN, Helena Carrascosa Von, PAGIOLA Stefano, TAFFARELLO, Denise (Org.). Experiências de pagamento por serviços ambientais no Brasil. São Paulo: Secretaria do Meio Ambiente: 2012. Cap. 11, p.167-178.

SAMPIERI, Roberto Hernández et al. Metodologia de pesquisa. 3. ed. São Paulo: McGrawHill, 2006.

SAMUELSON, Paul Anthony. Economia e política. São Paulo: Macgraw Hill, 1987.

SANTILLI, Márcio, et al. Tropical deforestation and the Kyoto Protocol: an editorial essay. Belém: Instituto de Pesquisa Ambiental da Amazônia, 2000.

SELLTIZ, C. et al. Métodos de pesquisa na relações sociais. 3. ed. São Paulo: Herder: Edusp, 1967.

SIMPSON, L. Factors prerequisite to market-based transfers of water. Trabalho não publicado. Washington, DC: World Bank, 1993.

STIGLITZ, Joseph E.; WALSH, Carl E. Introdução à microeconomia. Tradução de Helga Hoffmann. São Paulo: Campus, 2003.

SZTAJN, Rachel. Teoria jurídica da empresa: atividade empresarial e mercado. São Paulo: Atlas, 2004.

SWALLOW, B. et al. Compensation and rewards for environmental services in the developing world: framing pan-tropical analysis and comparison. ICRAF Working Paper $\mathrm{n}^{\mathrm{o}}$. 32. Nairobi: World Agroferestry Centre, 2007.

TOLEDO FILHO, Jorge Ribeiro. Mercado de capitais brasileiro. Campinas: Lucre, 1997. 
TROSTER, Roberto Luís. Introdução à microeconomia. In: PINHO, Diva Benevides; VASCONCELLOS, Marco Antonio S. de; TONETO JR., Rudnei (Org.). Manual de Economia. 6. ed. São Paulo: Saraiva, 2011. Cap. 8, p. 204-216.

VAN HAUWERMEIREN, Saar. Manual de economía ecológica. Abya-Yala, Quioto, Equador, 1999.

VASCONCELOS, Marco Antonio Sandoval de. Introdução à microeconomia. In: PINHO, Diva Benevides; VASCONCELlOS, Marco Antonio S. de; TONETO JR., Rudnei (Org.). Manual de Economia. 6. ed. São Paulo: Saraiva, 2011. Cap. 4, p. 109-114.

VARIAN, Hal R. Microeconomia. Tradução de Elfio Ricardo Doninelli e Regina Célia Simille de Macedo. Rio de Janeiro: Elsevier, 2012.

VEIGA NETO, Fernando Cesar da. A construção dos mercados de serviços ambientais e suas implicações para o desenvolvimento sustentável no Brasil. Seropédica, 2008. Tese (Doutorado) - Instituto de Ciências Humanas e Sociais do Curso de Pós-Graduação em Desenvolvimento, Agricultura e Sociedade - CPDA, da Universidade Federal Rural do Rio de Janeiro.

VIOLA, Eduardo. Regime internacional de mudança climática e o Brasil.Revista Eco 21. ano XII, n. 66, maio 2002.

WILLIAMSON, O. The economic institucions of capitalims: firms, markets, relational contracting. New York: The Free Press, 1985. 450p.

. Transaction cost economics and organization theory. Journal of Industrial and Corporate Change. v. 2, n. 2, p. 107-156, 1993.

. The mechanisms of governance. New York: Oxford University Press, 1996.

WORLD TRADE ORGANIZATION. Disponível em: < http://www.wto.org>. Acesso em: 05 abr. 2013.

WUNDER, S. Payments for environmental services: some nuts and bolts. CIFOR Occasional Paper $n^{\circ}$ 42. Bogor: CIFOR, 2005.

The efficiency of payments for environmental services in tropical conservation. Conservation Biology, Washington. v. 21, n. 1, p. 48-58, May 2007.

WUNDER, S. et al. Pagamentos por serviços ambientais: perspectivas para a Amazonia Legal. 2. ed. Brasília: MMA, 2009.

ZYLBERSZTAJN, Decio. Estrutura de governança e coordenação do agribusiness: uma aplicação da Nova Economia das Instituições. São Paulo, 1995. Tese (Livre-Docência) Departamento de Administração, Faculdade de Economia, Administração e Contabilidade, Universidade de São Paulo.

ZYLBERSTAJN, Decio et al. Direito e economia. Rio de Janeiro: Elsevier, 2005. 
ZOLIN, C. A. Análise e otimização de projetos de pagamentos por serviços ambientais (PSA) utilizando sistemas de informações geográficas (SIG) - o caso do município de extrema (MG). Piracicaba, 2010. Tese (Doutorado em Ciências) - Escola Superior de Agricultura "Luiz de Queiróz”, da Universidade de São Paulo.

ZÚÑIGA, Jorge M. Rodríguez. Pago por los servicios ambientales: la experiencia de Costa Rica. Disponível em: <http://www.fao.org/docrep/005/y4744s/y4744s08.htm>. Acesso em: 09 dez. 2011.

YIN, Robert K. Estudo de caso: planejamento e métodos. Tradução Ana Thorell. 4. ed. Porto Alegre: Bookman, 2010. 


\section{APÊNDICE 1}

\section{ROTEIRO DE ENTREVISTA AOS GESTORES DOS PROJETOS DE PSA}

\begin{tabular}{|l|l|}
\hline Identificação do Projeto: & Região de Abrangência: \\
\hline Nome: & E-mail: \\
\hline Função no Projeto: & Telefone: \\
\hline
\end{tabular}

1. Qual (is) o(s) serviço (s) ambientais fazem parte do projeto de PSA desenvolvido?

2. A divulgação do PSA envolve um trabalho de motivação e esclarecimento aos ofertantes e demandantes do serviço ambiental? Em caso afirmativo, qual (is) o(s) meio(s) de comunicação utilizado(s) para que os atores tomem conhecimento do teor do projeto? Essa via de comunicação foi eficiente? Quais suas vantagens de desvantagens?

3. A partir do trabalho de divulgação do PSA, quais foram as barreiras impostas na adesão dos ofertantes?

4. Como foram identificadas a necessidade e a razão, para implantação de PSA nessa região?

5. De quem foi a iniciativa de implantação do PSA dos demandantes, dos ofertantes ou de outras instituições?

6. Um dos pontos altos nos projetos de PSA é a escolha dos critérios de remuneração pelos serviços ambientais. Como foram escolhidos os critérios técnicos para remuneração pelos serviços ambientais? Os ofertantes e os demandantes participaram dessa escolha?

7. Quais arranjos institucionais ${ }^{122}$ foram criados para que o projeto pudesse ser implantado?

8. Qual o papel da instituição no desenvolvimento do PSA?

9. Qual é estrutura básica do PSA, e como se dá seu funcionamento?

10. Se houver o interesse de um ofertante (produtor rural) em participar do projeto, quais as primeiras ações?

11. Quais dados iniciais do ofertante (produtor rural) são necessários para que ele possa participar do projeto?

12. Qual a fonte de financiamento utilizada para pagamento aos ofertantes pela prestação do serviço ambiental? Qual a modalidade e o nível de recursos disponíveis?

13. Qual é a frequência do recebimento (mensal, trimestral ou anual) pelo ofertante da remuneração pela prestação do serviço ambiental? Esse pagamento ocorre de que forma?

14. Como ocorre e quem é o responsável pelo monitoramento da prestação do serviço ambiental, por parte do ofertante?

15. Qual a frequência do monitoramento (mensal, trimestral ou anual) da prestação do serviço ambiental?

16. No projeto do PSA está prevista a avaliação da satisfação do ofertante e do demandante?

17. Em sua opinião, quais os pontos fortes e fracos do PSA?

\footnotetext{
${ }^{122} \mathrm{O}$ arranjo institucional é aquele entre unidades econômicas que administram o meio pelo qual tais unidades podem cooperar (...) ou podem fornecer um mecanismo passível de proporcionar uma mudança nas leis ou no direito de propriedade. (WILLIAMSON, 1996, p. 103)
} 
18. Em sua opinião, a região onde foi desenvolvido o PSA teve avanços ambientais e melhoria de resultados econômicos?

19. Quais as cláusulas contratuais de que o demandante e o ofertante têm conhecimento?

20. Em que período ocorreu (ou ocorreram) quebra(s) contratual(is)? Quais foram os motivos e como estes foram detectados?

21. Em qual legislação ambiental o projeto está fundamentado?

22. Quais os benefícios para o projeto da aprovação de uma legislação específica sobre pagamento por serviços ambientais?

23. Partindo-se da premissa de que o ambiente institucional é baseado em regras políticas, sociais e legais fundamentais, que estabelecem a base para a produção, a troca e a distribuição, qual sua avaliação do ambiente institucional onde funciona o PSA? 


\section{APÊNDICE 2}

\section{TERMO DE CONSENTIMENTO DE LIVRE ESCLARECIMENTO}

\section{Prezado (a) Senhor (a)}

Otília Denise Jesus Ribeiro, do Curso de Doutorado em Administração, na Faculdade de Administração, Economia e Contabilidade (FEA) da Universidade de São Paulo (USP) está realizando uma pesquisa científica para a conclusão do seu curso. Para o alcance do problema definido no projeto de pesquisa é imprescindível a obtenção de informações e dados a serem fornecidos por técnicos especialistas gestores dos Projetos de Pagamento por Serviços Ambientais - PSA do Programa Produtor de Águas, o que se refere aos seguintes aspectos: (i) os arranjos institucionais formados para o desenvolvimento do PSA, (ii) o ambiente institucional onde o PSA foi implantado, (iii) a função desempenhada pelas instituições e atores envolvidos em cada um dos PSAs, (iv) a metodologia de cálculo utilizada para remuneração do serviço ambiental, (v) a fonte de recursos utilizadas para a remuneração dos serviços ambientais; (vi) a metodologia de monitoramento da prestação do serviço ambiental; (vii) os direitos e as obrigações dos ofertantes e dos demandantes; (viii) a identificação das transações ocorridas entre demandante e ofertante; (ix) as percepções dos atores sobre os PSA, entre outras informações relevantes para o conhecimento de cada projeto.

Dessa forma, solicita suas ordens no sentido de disponibilizar o mínimo de tempo possível para as entrevistas com os técnicos especialistas gestores dos projetos de PSA. Igualmente, esclarece-se que a pesquisa segue as regras de comportamento ético respeitando a confiabilidade dos dados e das informações fornecidos. A leitura do presente texto é muito importante porque esclarece todas as dúvidas a julgar necessárias.

Título da Tese: Serviços ambientais e os incentivos para a criação de mercados.

Pesquisadora: Otília Denise Jesus Ribeiro, doutoranda em Administração pela FEA/USP e Professor Assistente da Universidade Federal de Santa Maria (UFSM) - RS. E-mail denisejr@terra.com.br, e Telefone: (055) 96550095.

Orientador da Pesquisa de Doutorado: Professor Dr. Decio Zylbersztajn da FEA Universidade de São Paulo.

\section{Descrição do Projeto de Pesquisa}

$\mathrm{O}$ projeto de pesquisa tem como questão central investigar quais são os pressupostos/condições para o surgimento de mercados de serviços ambientais. O tema de pagamento por serviços ambientais é um problema complexo que representa um desafio para os pesquisadores, a comunidade científica em geral, e a sociedade como um todo. Visto de forma ampla, trata-se de uma questão de surgimento de um mercado mais do que um problema de precificação. Ora, no caso de serviços ambientais, observa-se que existem pagamentos por serviços ambientais, que não demonstram sustentabilidade ao longo do tempo, especialmente, quanto à origem dos recursos alocados. Não se tem visto a ação espontânea de agentes, ofertantes e demandantes, efetuando trocas de bens ou serviços. O que se observa são instituições públicas ou privadas, essas últimas em sua maioria, oriundas de organizações sem fins lucrativos, operando programas específicos e pontuais, cuja permanência depende de decisões de cunho político. Ou seja, aparentemente, não existem mercados operando, conforme o conceito econômico. A pesquisa é muito útil e sua participação é de grande valor, haja visto, a lacuna existente no tema sobre o mercado de serviços ambientais sob a ótica econômica. Ressalva-se que os dados não serão analisados de forma individual, mas, serão tabulados em conjunto, de forma que o nome do entrevistado e as respostas, não serão apresentados no trabalho. Portanto, a pesquisa ganha o merecido relevo no ambiente econômico visando demonstrar as particularidades do mercado de serviços ambientais.

São Paulo, março de 2013 
Otília Denise Jesus Ribeiro

Consentimento de Participação e Assinatura do Entrevistado

Tendo e lido e compreendido o texto acima descrito, eu concordo de livre espontânea vontade em participar da pesquisa dirigida por Otília Denise Jesus Ribeiro, doutoranda em Administração FEA/USP - Universidade de São Paulo.

\begin{tabular}{|l|l|l|}
\hline Data & Nome do Entrevistado & Assinatura \\
\hline Data & Nome do Entrevistador & Assinatura \\
\hline
\end{tabular}




\section{ANEXO 1}

\section{Modelo de contrato para PSA entre pessoas físicas ou jurídicas de direito privado}

Entre os abaixo $\square$ assinados a saber, de um lado o senhor maior de idade, identificado com o registro de identidade domiciliado na cidade de

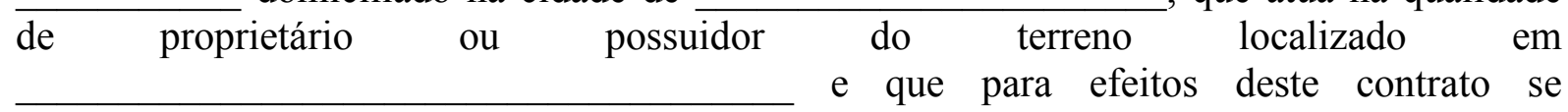
denominará PROVEDOR DO SERVIÇO, de uma parte, e da outra com o registro de identidade de maior de idade, identificado própria ou na qualidade de representante legal e que para efeitos deste contrato se denominará COMPRADOR DO SERVIÇO, celebra $\square$ se o seguinte contrato que será regido pelas seguintes cláusulas: PRIMEIRA: OBJETO. O COMPRADOR DO SERVIÇO, mediante a celebração deste contrato, realiza um reconhecimento econômico do serviço ambiental ao PROVEDOR DO SERVIÇO, pelo desenvolvimento das atividades necessárias para o mantimento, conservação, ou incremento do serviço ambiental selecionado ou para prover um novo. SEGUNDA: VALOR E FORMA DE PAGAMENTO. O valor deste contrato é de (valor este associado diretamente com a utilidade da atividade produtiva que se deixará de realizar e do qual derivam $\square$ se as obrigações de fazer ou não fazer, às quais se compromete o provedor para garantir a prestação do serviço). TERCEIRA: PRAZO. É o tempo fixado para o cumprimento. O prazo estipulado deverá ser razoável, isto é, que permita o cumprimento do objeto do projeto ou desenho que se propôs para tal fim. QUARTA: OBRIGAÇÕES DAS PARTES. DO PROVEDOR DO SERVIÇO. A de fazer ou não fazer algo que garanta o mantimento ou incremento do serviço. DO COMPRADOR DO SERVIÇO. a) Estabelecer a concordância entre o programa ou projeto e as políticas ou planos ambientais relevantes na área onde se situa; b) Registrar o programa ou projeto perante a Autoridade Ambiental; c) Reportar à Autoridade Ambiental as informações relacionadas com a execução com base em um formato pré $\square$ estabelecido. d) Verificar que por efeito e de conformidade com a metodologia estabelecida que a ação ou inação esteja diretamente relacionada com a prestação do serviço ambiental para poder ser efetuado o pagamento ou reconhecimento econômico correspondente. e) Realizar o reconhecimento econômico correspondente. QUINTA: CLAÚSULA COMPROMISSÓRIA. Este contrato deverá contar com cláusulas compromissórias, que assegurem não somente o cumprimento das obrigações mas também que em caso de não se cumprirem, possa a parte cumpridora exigir a indenização pelos prejuízos causados.

Para vigência se assina em aos ) dias do mês de de dois mil $(20 \quad)$. 
ANEXO 2

Modelo de contrato para PSA públicos ou mistos

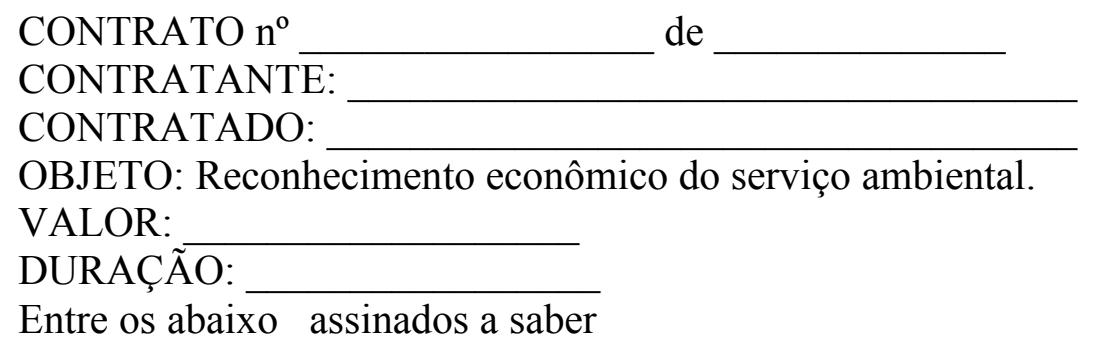

Entre os abaixo $\square$ assinados a saber cidade de identificado com o registro de identidade , trabalhando em sua qualidade de representante legal da Corporação Autônoma Regional os efeitos do presente Convênio se chamará COMPRADOR DO SERVIÇO ou CORPORAÇÃ̃O e de outro lado, identificado com o registro de identidade representação de de que trabalha em identificado com NIT.* e que daqui em diante se denominará simplesmente $\mathbf{O}$ PROVEDOR DO SERVIÇO, por outra parte, celebra $\square$ se o presente contrato, descrito e contido nas seguintes cláusulas, prévias as considerações que a seguir se assinalam: A) Que em desenvolvimento dos programas de política nacional ambiental e as obrigações que em virtude da Lei 99/93** encontram $\square$ se atribuídas à Corporação, é viável a participação conjunta entre entidades públicas e privadas para alcançar os objetivos e metas ambientais. B) Que a Corporação é uma Entidade Estatal de Ordem Nacional, criada pela Lei 99/93 e portanto sujeita a aplicar em seus processos contratuais o Decreto 2170 de 2002. C) Que de acordo com o estabelecido no Decreto 2170 de 2002, as Entidades Públicas de $\square$ vem cumprir com o princípio de publicidade em matéria contratual mediante a divulgação das etapas pré $\square$ contratual, contratual e pós $\square$ contratual na página eletrônica da entidade ou em um meio de divulgação que faça as suas vezes. D) Que dada a natureza jurídica, poderá contratar $\square$ se diretamente a uma pessoa Física ou Jurídica, para desenvolver o projeto de pagamento por serviços ambientais, de acordo com os delineamentos técnicos definidos no projeto formulado pela mesma Corporação. Feitas as anteriores considerações as partes acordam as seguintes cláusulas: PRIMEIRA: OBJETO. O objeto do presente contrato é o reconhecimento econômico do serviço ambiental de

PARÁGRAFO

PRIMEIRO: O PROVEDOR DO SERVIÇO se sujeitará totalmente aos termos estabelecidos pela Corporação e ao projeto formulado para tal fim que fazem parte integrante do presente contrato. SEGUNDA: OBRIGAÇÕES DAS PARTES: OBRIGAÇÕES DO PROVEDOR DO SERVIÇO. Fazer ou não fazer algo que garanta o mantimento ou incremento do serviço. OBRIGAÇÕES DO COMPRADOR DO SERVIÇO. a) Realizar o reconhecimento econômico do serviço ambiental ao provedor. b) Verificar que por efeito e de conformidade com a metodologia estabelecida, que a ação ou inação estejam diretamente relacionadas com o serviço ambiental para poder efetuar o pagamento ou reconhecimento econômico correspondente. TERCEIRA PRAZO DO CONTRATO: O prazo do contrato se define como o tempo estabelecido para o cumprimento do contrato. O dito prazo deverá ser razoável, isto é, que permita o cumprimento do objeto do projeto ou desenho que se propôs para tal fim. QUARTA: VALOR DO CONTRATO. Para efeitos do presente contrato, o valor deste contrato estaria associado diretamente com a utilidade da atividade produtiva que se deixará de realizar e do qual derivam $\square$ se as obrigações de fazer ou não fazer, às quais se compromete o provedor para garantir a prestação do ser $\square$ viço QUINTA: FORMA DE 
PAGAMENTO. Esta deverá estar estipulada no contrato e as metodologias que se utilizarão para monitorar o uso do solo, que é o suporte técnico do valor a pagar SEXTA: SUPERVISÃO E CONTROLE. A Corporação supervisionará e controlará a correta execução do presente contrato, por meio do dependência da Corporação Autônoma Regional de que terá além das funções que pela índole e natureza do contrato lhe sejam próprias, as seguintes: a) Certificar a prestação do serviço contratado dentro das condições exigidas. b) Revisar os relatórios de trabalhos que devam render o PROVEDOR DO SERVIÇO à CORPORAÇÃO. c) Levantar e firmar as atas respectivas. SÉTIMA: TERMINAÇÃO, MODIFICAÇÃO E INTERPRETAÇÃO UNILATERAIS DO CONTRATO. Em conformidade com o disposto no Artigo 14 da Lei 80 de 1993, o presente contrato poderá ser terminado unilateralmente.

Em vigência, se assina na cidade de , aos

\section{O COMPRADOR}

\section{O PROVEDOR DO SERVIÇO}

* NIT: Número de Inscrição do Trabalhador. [N.E.]

** A Lei 99/93 define os fundamentos da Política Ambiental Colombiana. Os modelos de contratos apresentados neste livro foram desenvolvidos na Colômbia e traduzidos para o português pelos autores. [N.E.] 
Termo de Compromisso entre Município de Extrema e Produtor Rural - Projeto Conservador das Águas

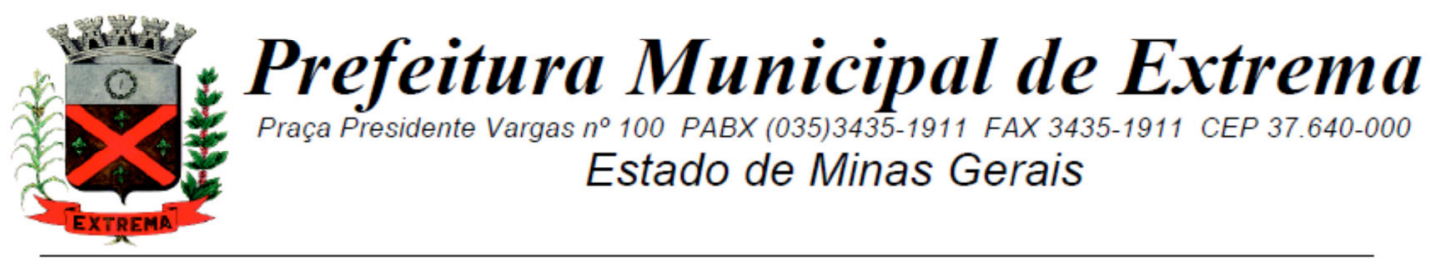

\begin{abstract}
TERMO DE COMPROMISSO N $N^{\circ}$ S01/2014
PARA O CUMPRIMENTO DAS METAS

ESTABELECIDAS PELA LEI MUNICIPAL

2.100/05 E DECRETO MUNICIPAL

2.409/10 - PROJETO CONSERVADOR

DAS AGUAS.
\end{abstract}

Pelo presente instrumento, o Sr. XXXXXXXX, estabelecido no município de Extrema, CPF $n^{\circ}$ XXXXXXX, doravante denominado produtor rural e o MUNICÍPIO DE EXTREMA, neste ato representado pelo prefeito Dr. Luiz Carlos Bergamin, resolvem celebrar o seguinte TERMO DE COMPROMISSO, mediante as seguintes condições:

\title{
CLÁUSULA PRIMEIRA
}

O PRODUTOR RURAL é proprietário de área de terra denominada Sítio São Domingos, matrícula $\mathrm{n}^{\circ} \mathrm{XXXX}$, localizada no bairro do Salto, município de Extrema com área total de 18 hectares (ha), onde será implantado o Projeto Conservador das Águas visando à implantação de ações para melhoria da qualidade e quantidade das águas, através do cumprimento das seguintes metas:

Meta 1 - Práticas Conservacionistas de Solo para controle de erosão em 14,40 ha.

Meta 2 - Implantação de Sistema de Saneamento Ambiental.

Meta 3 - Implantação e manutenção da cobertura vegetal das Áreas de Preservação Permanente e Cadastro Ambiental Rural da Reserva Legal em 3,60 ha.

Os investimentos para o cumprimento das metas, serão de responsabilidade do Municipio de Extrema e entidades conveniadas.

Estas áreas poderão sofrer alterações conforme necessidades operacionais e técnicas no andamento do projeto

\section{CLÁUSULA SEGUNDA}

O Proprietário Rural receberá como apoio financeiro o valor de 100 ( cem ) Unidade Fiscal de Extrema (UFEX), correspondente a R $\$ 221,00$, por hectare por ano, que representa R\$ 3.978,00 (três mil novecentos e setenta e oito reais), dividido em doze parcelas fixas mensais de $R \$ 331,50$ (trezentos e trinta e um reais e cinquenta centavos), a serem depositadas até o dia 12 (doze) de cada mês na Conta Bancária Banco Bradesco, Agência XXXXX, Conta Corrente $n^{\circ}$ XXXXX, após elaboração do Atestado Técnico.

Este Termo de Compromisso terá validade de 4 anos, corrigido anualmente nos meses de janeiro conforme Decreto Municipal que fixa o valor da UFEX. 


\section{CLÁUSULA TERCEIRA}

Na propriedade acima descrita, o Produtor Rural declara que manterá as ações executadas pela Prefeitura de Extrema através da Secretária de Meio Ambiente e permitirá o livre acesso nas áreas trabalhadas pela equipe da Prefeitura e das entidades conveniadas.

\section{CLÁUSULA QUARTA}

O Produtor Rural deverá seguir criteriosamente as instruções contidas no PROJETO TÉCNICO anexo, mantendo e executando todas as fases corretamente e protegendo a área contra a ação do fogo, de animais e de terceiros, controlar corretamente as principais pragas, manter o sistema de saneamento ambiental e de controle da erosão operando satisfatoriamente.

Declara conhecimento das leis e normas que regulam a política florestal e de proteção à biodiversidade e assume o compromisso de acatá-las fielmente $e$, que não está em andamento de ação judicial, tendo por objeto a propriedade ou posse da área em questão.

\section{CLÁUSULA QUINTA}

No caso do não cumprimento pelo Produtor Rural das metas de manutenção previstas neste TERMO, atestadas por Relatório de Visita Téenica emitido pelo Técnico do Departamento de Meio Ambiente, até o último dia útil de cada mês, o Produtor Rural deixa de receber o apoio financeiro.

\section{CLÁUSUla SEXTA}

Todos os recursos provenientes dos créditos de mercado de carbono gerados nesta propriedade pelos próximos trinta anos, serão creditados integralmente na conta do Fundo Municipal para Pagamento por Serviços Ambientais, instituído pela Lei Municipal n 2.482 de 13 de fevereiro de 2009.

\section{CLÁUSULA SÉTIMA}

Fica registrado o foro da cidade de Extrema, como competente para dirimir dúvidas advindas no presente Termo.

E por estarem as partes justas e conveniadas, assinam o presente instrumento, em 04 (quatro) vias de igual teor e forma, na presença das testemunhas abaixo-assinados.

Extrema, 02 de janeiro de 2014.

\section{Dr. Luiz Carlos Bergamin Prefeito}

Testemunhas:
XXXXXXXXXXX

RG XXXXXXXX SSP MG

Produtor Rural
Paulo Henrique Pereira
CPF - XXXXXXXXXXX
Benedito Arlindo Cortez CPF - XXXXXXXXX 
ANEXO 4

Contrato Projeto Produtores de Água e Floresta do Comitê das Bacias Hidrográficas dos Rios Guandu do Guarda e Guarda-Mirim - Comitê Guandú

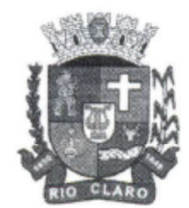

\section{Prefeitura Municipal de Rio Claro}

Secretaria Municipal de Meio Ambiente de Rio Claro Avenida João Batista Portugal, 367. Centro, Rio Claro/RJ, CEP 27.460-000. Telefone: (24) 33321717. Ramal 236.

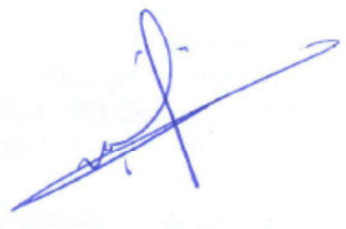

CONTRATO $N^{\circ}$ 59/2012
CUMPRIMENTO DARA O
ESTABELECIDAS NO ÂMBITO DO
PROJETO PRODUTORES DE AGUA E
FLORESTA, DO COMITE DAS BACIAS
HIDROGRÁFICAS DOS RIOS GUANDU,
DO GUARDA E GUARDA-MIRIM -
COMITEE GUANDU.

Pelo presente instrumento, a Senhora Maria de Lourdes Albers Pereira, brasileira, portadora da Carteira de Identidade $n^{\circ} 599.418$ expedida em 26/10/1973 pelo Instituto Pereira Faustino do CPF/MF n 497.405.637-91, proprietária rural dos Sítios Santo Antônio e Santa Maria e parte da Fazenda Talismã, todos imóveis localizados à Estrada Fazenda Roça Grande, S/N, Rio Claro/RJ, doravante denominada Produtora de Áqua e Floresta e a Prefeitura Municipal de Rio Claro, sediada à Avenida João Batista Portugal, 367. Centro, Rio Claro/RJ, CEP 27.460-000, inscrita no CNPJ/MF sob $n^{\circ} 29.051 .216 / 0001-68$, neste ato representada pelo Prefeito Dr. Raul Fonseca Machado, brasileiro, casado, médico, portador da Cédula de Identidade $n^{\circ} 5235162-5$, emitida pelo CRM, CPF $n^{\circ}$ 469.799.647-04, e pelo Secretário de Meio Ambiente e Agricultura, Mário Vidigal Barbosa Júnior, brasileiro, solteiro, biólogo, portador da Cédula de Identidade $\mathrm{n}^{\circ}$ 06772565-5 do IFP, CPF $n^{\circ}$ 828.658.417-15, com interveniência da Unidade Gestora do Projeto Produtores de Água e Floresta, doravante denominada UGP e representada por sua Secretaria Executiva, INSTITUTO TERRA DE PRESERVAÇÃO AMBIENTAL, pessoa jurídica de direito privado, sem fins lucrativos, inscrito no CNPJ/MF sob o $n^{\circ}$ 02.575.919/0001-39, doravante denominado ITPA, com sede à Rua Chaumiére 1.411, Barão Javari, Miguel Pereira/RJ, neste ato representado por seu Secretário-Executivo, Maurício Ruiz Castello Branco, brasileiro, casado, portador da carteira de identidade $\mathrm{n}^{\circ}$ 11868728-4, expedida pelo DETRAN/RJ, inscrito no CPF/MF sob o $n^{\circ} 54594047-89$, resolvem celebrar o seguinte CONTRATO:

\section{CLÁUSULA PRIMEIRA - DO OBJETO}

1.1 - O projeto piloto PRODUTORES DE ÁGUAS E FLORESTAS se propõe a aplicar o modelo provedor-recebedor, por meio de um sistema de pagamentos por serviços ambientais incentivando, mediante compensaçäo financeira, os agentes que comprovadamente adotarem, contribuirem ou implementarem práticas para a proteção e recuperação de mananciais, auxiliando a recuperação do potencial de geração de serviços ecossistêmicos, provendo beneficios às bacias hidrográficas e à sociedade em geral.

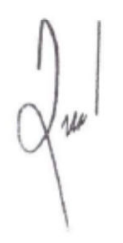




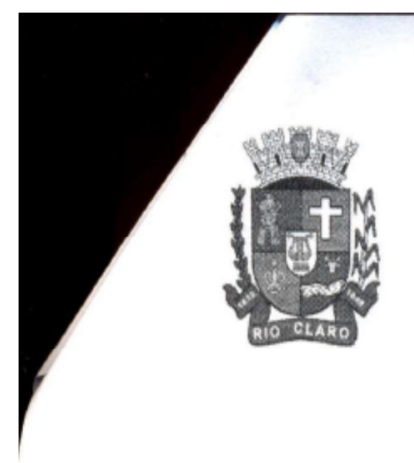

\section{Prefeitura Municipal de Rio Claro}

Secretaria Municipal de Meio Ambiente de Rio Claro Avenida João Batista Portugal, 367. Centro, Rio Claro/RJ, CEP 27.460-000. Telefone: (24) 33321717. Ramal 236.

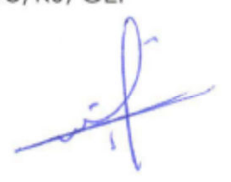

1.2 - O presente CONTRATO tem por objetivo, formalizar e viabilizar o pagamento pelo Serviço Ambiental prestado pela adoção, contribuição ou implementação de práticas de conservação e restauração da Mata Atlântica, ao proprietário discriminado por este termo como Produtor de Água e Floresta. Conforme condiçöes pré-definidas e cumprimento das metas previstas no Plano de Trabalho (ANEXO 1) para o periodo de vigência do contrato.

1.3 - O presente termo não constitui vinculo empregatício de qualquer natureza com o Produtor de Água e Floresta.

\section{CLÁUSULA SEGUNDA - DOS RECURSOS ORÇAMENTÁRIOS E FINANCEIROS}

2.1 - O pagamento por serviços ambientais ao Produtor de Água e Floresta integrante do projeto "Produtores de Água e Floresta" encontra-se em perfeito acordo com a legislação vigente, em especial com a Política Nacional de Recursos Hídricos (Lei $n^{0}$ 9.433/97), Lei Fluminense das Águas (Lei $n^{0} 3.239 / 99$ ), Lei $n^{0}$ 4.247/03 e Lei $n^{0} 5.234 / 08$ (Artigo 2, Inciso VII), e ao Contrato de Gestão nº. 03/2010-INEA-AGEVAP.

2.2 - O pagamento a ser realizado ao Produtor de Água e Floresta, será calculado tendo como valor de referência o custo de oportunidade local, associado a quatro parâmetros, conforme ANEXO 2, quais sejam: áreas em conservação e restauração (em ha), nivel de prioridade para a produção de água na bacia (APPs e Áreas Interceptoras de Água), estágio de sucessão dos remanescentes em conservação (Avançado/ Médio ou Inicial) e contexto geográfico de proximidade ou inclusão em unidades de conservação.

2.3 - $O$ pagamento ao Produtor de Água e Floresta, obedecerá a um plano de trabalho individual (ANEXO 1).

PARÁGRAFO ÚNICO - O pagamento ao Produtor de Água e Floresta se dará em duas parcelas fixas semestrais, posteriormente à avaliação do Laudo de Vistoria, a ser emitido pela secretaria executiva da UGP e também pela AGEVAP.

2.4 - O pagamento pelos serviços ambientais prestados está condicionado à avaliação das atividades desenvolvidas, em Laudo de Vistoria emitido pelo coordenador de projeto da UGP onde será observado o estado geral e os cuidados $\mathrm{com}$ as ações implantadas. A partir dele será emitida autorização de pagamento pela UGP para a execução pela Prefeitura Municipal de Rio Claro.

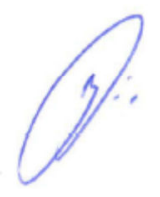




\section{Prefeitura Municipal de Rio Claro}

Secretaria Municipal de Meio Ambiente de Rio Claro Avenida João Batista Portugal, 367. Centro, Rio Claro/RJ, CEP 27.460-000. Telefone: (24) 33321717. Ramal 236.

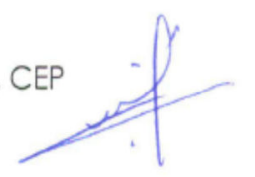

2.5 - A avaliaçăo do estado geral da área e dos cuidados mantidos pelo Produtor de Água e Floresta na prestaçăo dos serviços ambientais previstos neste CONTRATO deverão checar se o Produtor de Água e Floresta:

a. impediu ou dificultou o acesso da equipe do projeto aos locais de restauração ou conservação dentro da sua propriedade;

b. dificultou o desenvolvimento das açōes previstas no plano de trabalho, tais como: alteração de traçado ou de local de cercas;

c. danificou DIRETA OU INDIRETAMENTE cercas ou mudas implantas pelo projeto;

d. fez uso de fogo na propriedade, mesmo para limpeza de pasto sem a devida licença do órgão ambiental competente;

e. não informou IMEDIATAMENTE à Prefeitura Municipal de Rio Claro, através de contato direto ou através do responsável local do projeto, qualquer caso criminoso de depredação às cercas, mudas, áreas em restauração florestal ou áreas conservadas no âmbito deste CONTRATO de prestação de serviços ambientais;

f. não informou IMEDIATAMENTE ao responsável local do projeto qualquer caso que possa de alguma forma impedir ou dificultar o desenvolvimento das medidas de conservação ou restauração de florestas previstas no âmbito deste CONTRATO;

2.6 - A Prefeitura Municipal de Rio Claro deverá ser informada de todas as ocorrências acima citadas, tanto pelo Produtor de Água e Floresta, quanto pelo responsável técnico da UGP.

PARÁGRAFO PRIMEIRO: Entende-se como ato de depredação às áreas em restauração ou conservação, o uso de fogo, o corte de floresta ou de seu subbosque, 0 corte de cercas, a caça ou captura de animais silvestres.

PARÁGRAFO SEGUNDO: O Produtor de Água e Floresta é responsável pelas açöes de seus prepostos ou terceirizados no cumprimento das açöes previstas neste CONTRATO.

PARÁGRAFO TERCEIRO: $\mathrm{O}$ atendimento aos proprietários poderá ser realizado de segunda a sexta-feira, das 07:00h às 16:00h, pelos telefones: (24) 9966-2852, (24) 9826-7629 ou (21) 9557-0518 ou diretamente no escritório técnico da UGP no município de Rio Claro, em Lídice - Escola Municipalizada Rio das Pedras, ou na sede da Secretaria Municipal de Meio Ambiente, em Rio Claro, Avenida João Batista Portugal, 367. Centro, Rio Claro/RJ, CEP 27.460-000. Telefone: (24) 33321717. Ramal 236. Horário de funcionamento de segunda a sexta-feira, de 8 às 12 e de $13: 30$ às 17 horas. 


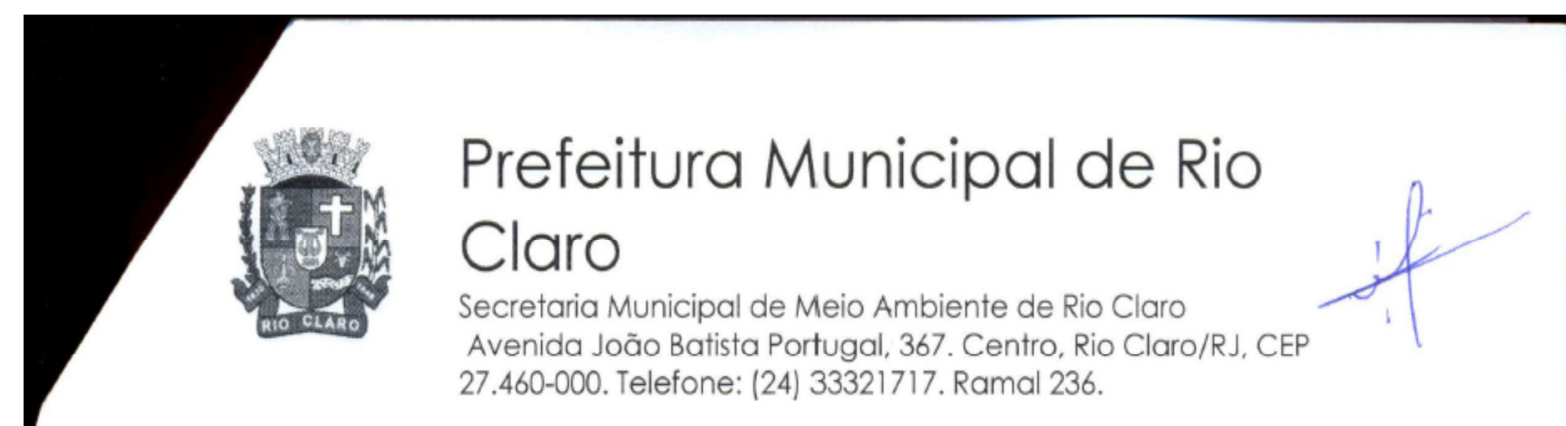

2.7 - Em caso de inconformidade ou descumprimento das metas e atividades contratadas a Prefeitura Municipal de Rio Claro poderá acionar as medidas cabíveis para garantir o ressarcimento dos recursos investidos ou remunerados.

\section{CLÁUSULA TERCEIRA - DAS OBRIGAÇÕES DAS PARTES}

3.1 - OBRIGAÇÕES DA UGP:

3.1.1 - Prestar apoio e assistência para o cumprimento das metas e atividades previstas no Plano de Trabalho, por meio de sua Secretaria Executiva, para o período de vigência deste CONTRATO;

3.1.2 - Garantir em tempo hábil, conforme Cláusula Terceira do Termo de Cooperaçäo Técnica assinado em 11/05/2009 e publicado no DOE/RJ em 18/08/2009, o cumprimento das responsabilidades e devidas contrapartidas para implantaçäo das medidas de restauraçäo e conservaçäo;

3.1.3 - Realizar, por meio de sua Secretaria Executiva, a emissão de laudos de vistoria das atividades realizadas pelo Produtor de Água e Floresta;

\section{2 - OBRIGAÇÕES DO PRODUTOR DE ÁGUA E FLORESTA:}

3.2.1 - Comprovar sua relação de dominio ou posse do imóvel/ área objeto da contratação, mediante documentação específica, conforme determinado no Edital de Seleção para propostas de prestação de serviços ambientais.

3.2.2 - Apresentar uma CARTA DE ANUÊNCIA confirmando a ciência e a concordância de todos os legalmente interessados, quando for o caso de domínio ou posse por mais de uma pessoa ou herdeiros, conforme determinado no Edital de Seleção.

3.2.3 - O Produtor de Água e Floresta deverá manter e zelar pelas açōes executadas na propriedade, protegendo a área contra a ação do fogo, de animais e de terceiros, sob avaliação conforme descrito no Item 2.5 .

3.2.4 - Deverá sempre, avisar e auxiliar a equipe técnica do projeto no controle eficaz e correto das principais pragas e ameaças, especialmente no caso de prejuizo iminente às cercas e reflorestamentos implantados, sob avaliação conforme descrito no Item 2.5.;

3.2.5 - O Produtor de Água e Floresta se compromete a cumprir, no periodo de 12 meses a partir da assinatura deste contrato, as metas de conservação e restauraçäo
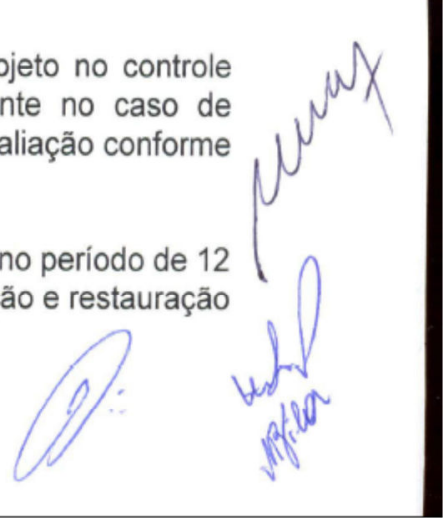


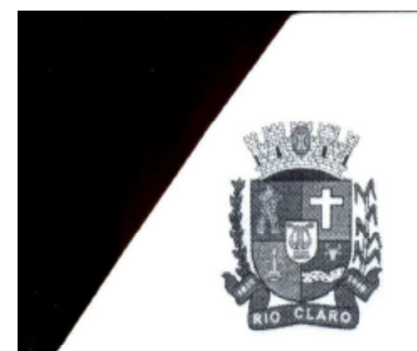

\section{Prefeitura Municipal de Rio Claro}

Secretaria Municipal de Meio Ambiente de Rio Claro

Avenida João Batista Portugal, 367. Centro, Rio Claro/RJ, CEP

27.460-000. Telefone: (24) 33321717. Ramal 236.

conforme Plano de Trabalho (ANEXO 1) apresentado em sua proposta, conforme determinado no Edital.

3.2.6 - Acompanhar a equipe do projeto no cumprimento do seguinte cronograma de atividades, para liberação das parcelas:

Parcela 1:

- Alocar/ Marcar áreas de restauração.

- Apresentar plano de trabalho detalhado (análise ambiental).

- Realizar isolamento de áreas (se necessário).

Parcela 2:

- Iniciar as açöes de restauração.

- Concluir atividades de implantação de medidas de restauraçāo.

- Manter açöes implantadas.

3.2.7 - Ter conhecimento das leis e normas que regulam a política florestal e de proteção à biodiversidade e assumir o compromisso de acatá-las fielmente e auxiliar na sua divulgação.

\section{3 - OBRIGAÇÕES DA PREFEITURA MUNICIPAL DE RIO CLARO:}

3.3.1 - Assegurar o desembolso dos recursos previstos ao Produtor de Água e Floresta, conforme Plano de Trabalho de acordo com condicionantes préestabelecidos na cláusula segunda;

3.3.2 - Com base nos Laudos de Vistoria elaborados pela Secretaria Executiva da UGP, certificar-se do cumprimento das obrigações do Produtor de Água e Floresta, para promover o desembolso;

3.3.3 - Verificar a compatibilidade técnica das propostas com o projeto básico, quanto à conservação e restauração, aprovado pelo Comitê Guandu;

3.3.4 - Celebrar contrato com o proponente à prestação de serviços ambientais, cuja proposta tenha sido selecionada;

3.3.5 - Manter atualizado o cadastro das propostas inscritas, habilitadas e priorizadas dando publicidade ao mesmo conforme descrito no edital;

3.3.6 - Manter o Comitê Guandu e Secretaria Executiva da Unidade Gestora do Projeto (UGP) informada sobre a existência de quaisquer eventos que dificultem ou interrompam o curso normal de execução do Contrato;

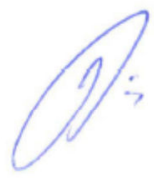




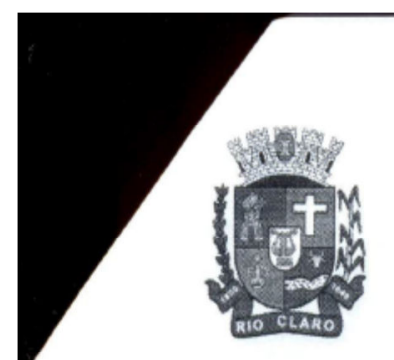

\section{Prefeitura Municipal de Rio} Claro

Secretaria Municipal de Meio Ambiente de Rio Claro Avenida João Batista Portugal, 367. Centro, Rio Claro/RJ, CEP 27.460-000. Telefone: (24) 33321717. Ramal 236.

3.3.7 - Realizar os pagamentos aos Produtores de Água e Floresta assim que houver a emissão da UGP de autorização dos pagamentos e transferência de recursos pela AGEVAP.

\section{4 - OBRIGAÇÕES DA AGEVAP:}

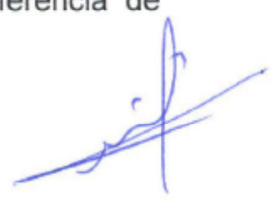

3.4.1 - Realizar as vistorias nas propriedades quando do cumprimento das metas;

3.4.2 - Participar das reuniões da UGP sempre que convidada;

3.4.3 - Realizar o repasse de recursos financeiros para a conta corrente de $n^{\circ}$ 13.769-3, Agência n 2539-9, Banco Brasil, vinculada ao Fundo Municipal de Defesa do Meio Ambiente da Secretaria Municipal de Meio Ambiente de Rio Claro, conforme contrato $\mathrm{N}^{\circ}$ 04/12 firmado entre a AGEVAP e o Município de Rio Claro, assinado em 11 de maio de 2012.

\section{CLÁUSULA QUARTA - DO PAGAMENTO AO PRODUTOR DE ÁGUA E FLORESTA}

4.1 - Os serviços de adoçăo, contribuição ou implementação de práticas de conservação e restauração da Mata Atlântica pelo Produtor de Água e Floresta serão remunerados em duas parcelas anuais, conforme CLÁUSULA SEGUNDA, mediante assinatura de recibo na sede da Secretaria Municipal de Meio Ambiente de Rio Claro, tanto para pessoa fisica como para pessoa jurídica;

4.2 - Para que a Prefeitura Municipal de Rio Claro possa efetivar o pagamento, o Produtor de Água e Floresta deverá apresentar toda a documentação pessoal ou institucional, assim como da área de intervenção direta (propriedade) que comprove a relação de domínio ou posse legal da área de intervenção, de acordo com o manual de orientação ao proponente de prestação de serviços ambientais.

4.3 - Não serão realizadas quaisquer retenções de impostos (INSS, Imposto de Renda e outros) do valor a ser pago ao Produtor de Água e Floresta.

\section{CLÁUSULA QUINTA - DA VIGÊNCIA E DA PRORROGAÇÃO}

5.1 - O presente CONTRATO vigorará pelo período máximo de 01 (um) ano, podendo ser prorrogado automaticamente por igual período, por vontade das partes

CLÁUSULA SEXTA - DO FORO 


\section{Prefeitura Municipal de Rio Claro}

Secretaria Municipal de Meio Ambiente de Rio Claro

Avenida João Batista Portugal, 367. Centro, Rio Claro/RJ, CEP

27.460-000. Telefone: (24) 33321717. Ramal 236.

6.1 - Para a solução de controvérsias provenientes da execução deste CONTRATO, as partes elegem o Foro da Comarca de Rio Claro - RJ.

E assim, estando justos e acordados, firmam o presente Contrato em 03 (vias) vias de igual teor e forma, para um só efeito de direito, na presença das testemunhas abaixo.

$$
\text { Rio Claro-RJ, em _ } 3 \text { de Lagoto de } 2012 .
$$
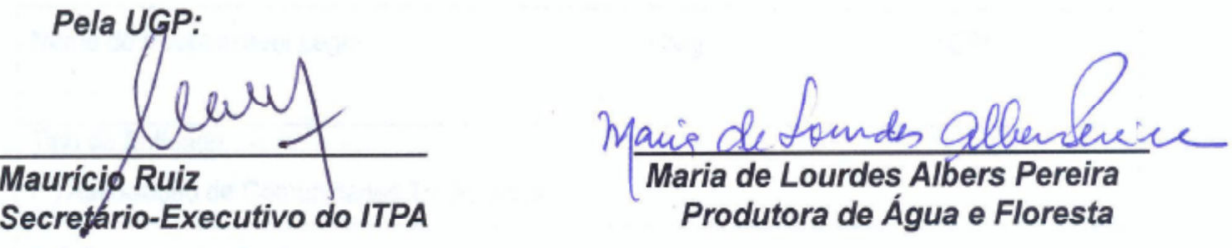

Pela Prefeitura Municipal de Rio Claro:
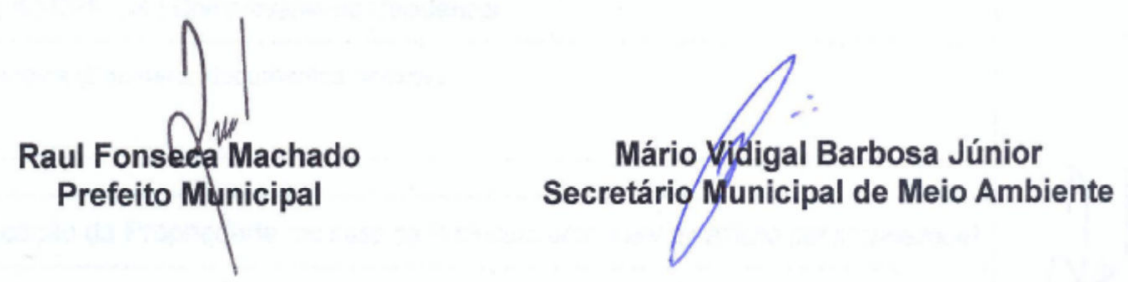

TESTEMUNHAS:
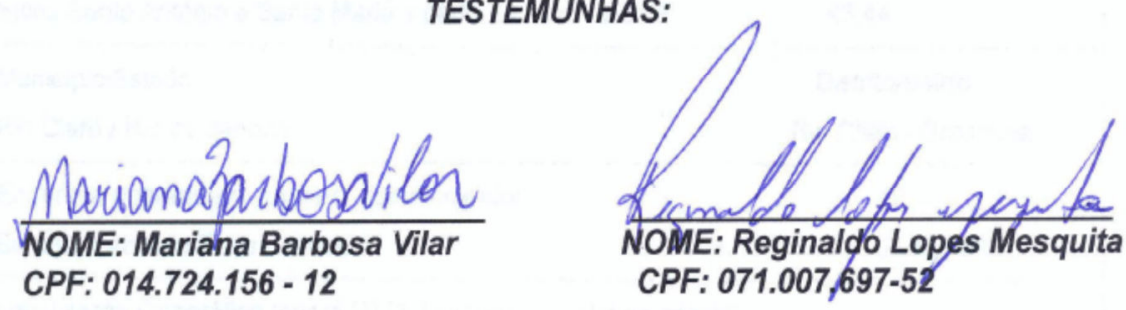

ANEXO 1-Plano de Trabalho

ANEXO 2 - Tabela de valoração 


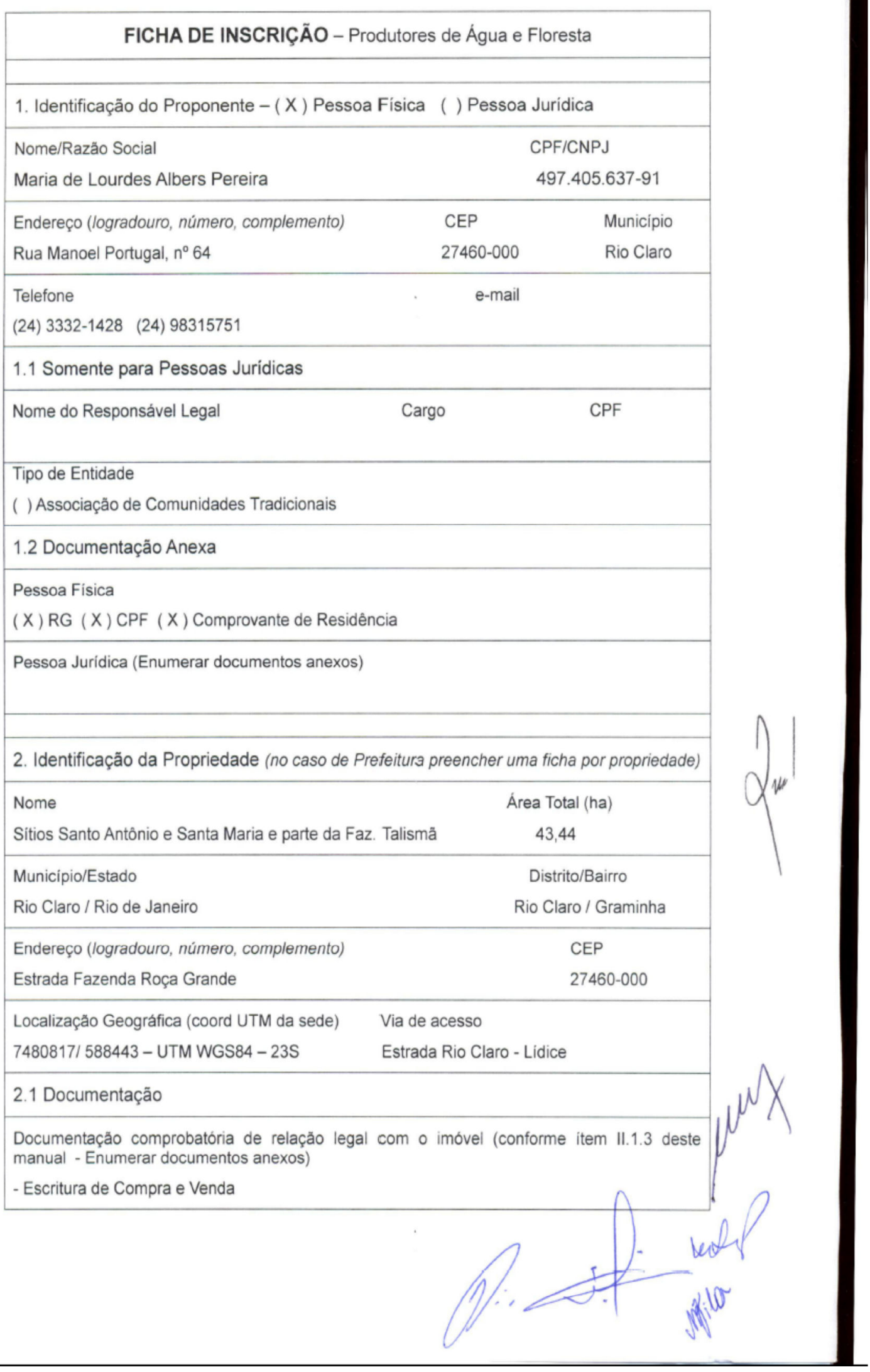




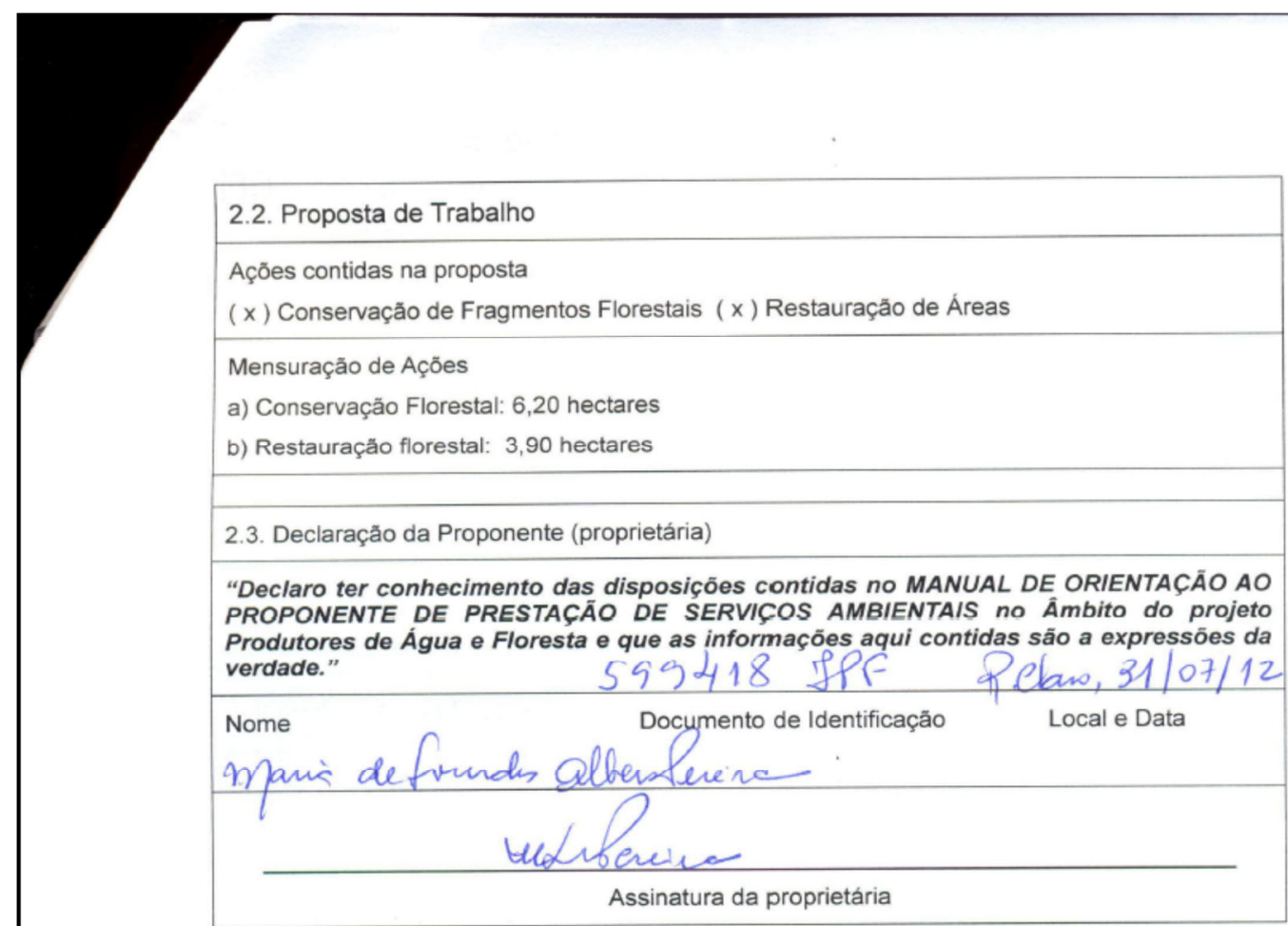
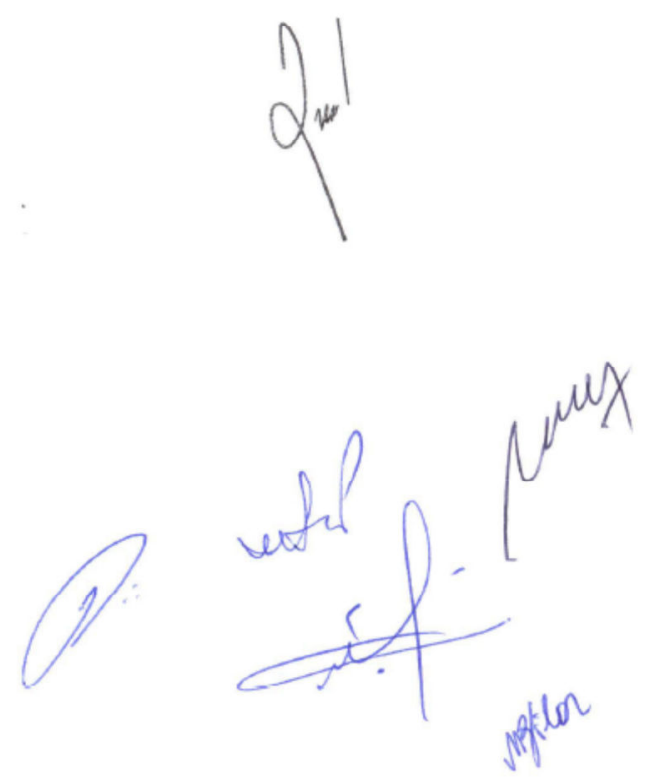


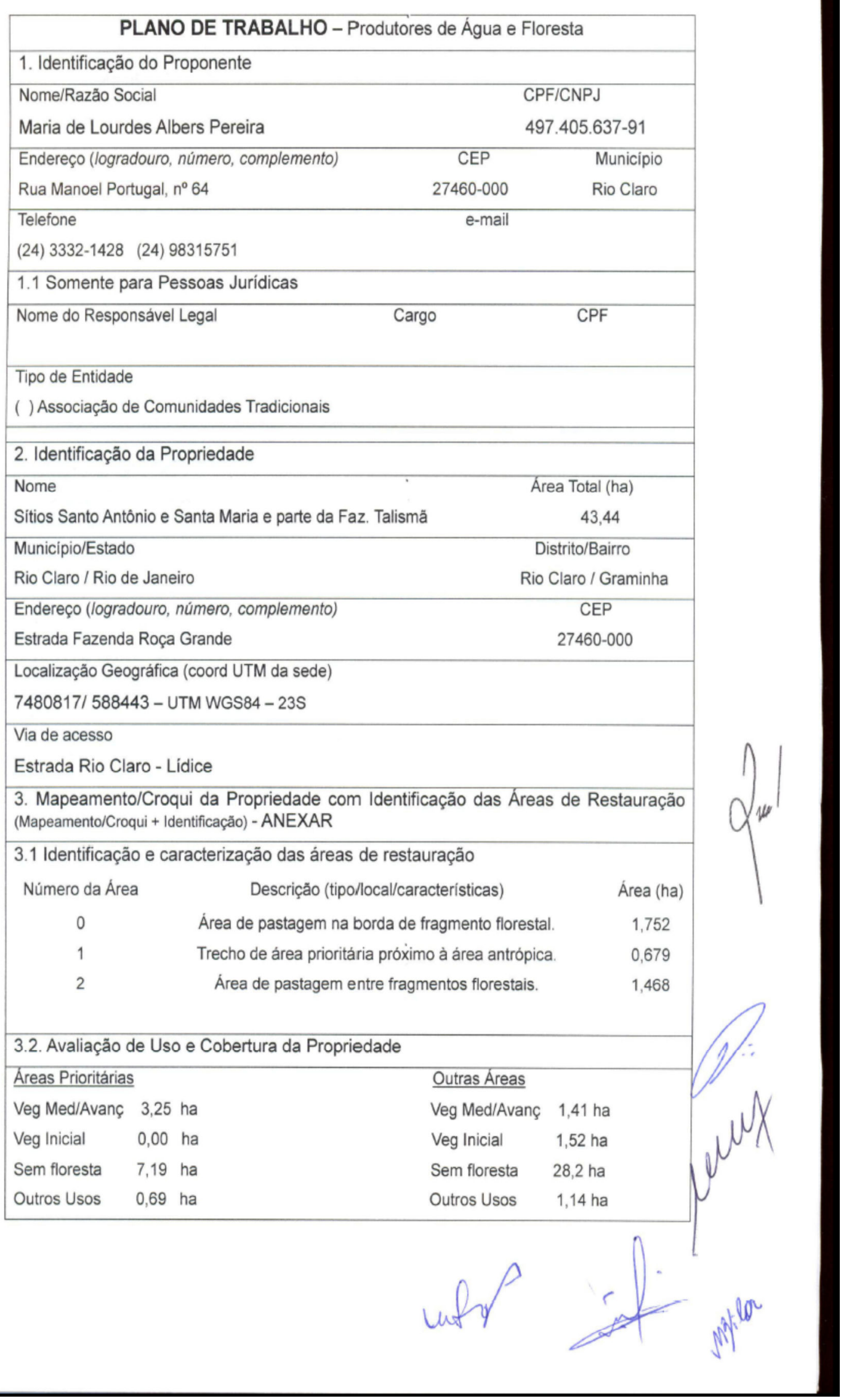


3.3. Proposta de Trabalho

Açŏes contidas na proposta

(X) Conservação de Fragmentos Florestais (X) Restąuraçăo de Áreas

Mensuração de Ações

a) Conservaçăo Florestal: 6,20 hectares

b) Restauração florestal: 3,90 hectares

\section{Atividades e Cronograma de Execução}

\begin{tabular}{|l|c|c|c|c|}
\hline & \multicolumn{4}{c|}{ Cronograma } \\
\hline \multicolumn{1}{|c|}{ ATIVIDADES } & Trimestre 1 & Trimestre 2 & Trimestre 3 & Trimestre 4 \\
\hline Alocação de Areas & $\mathrm{X}$ & & & \\
\hline $\begin{array}{l}\text { Análise Ambiental (Plano de } \\
\text { Trabalho Detalhado - PTD) }\end{array}$ & $\mathrm{X}$ & & & \\
\hline Isolamento de Areas & $\mathrm{X}$ & $\mathrm{X}$ & & \\
\hline $\begin{array}{l}\text { Ações de Restauração } \\
\text { Projetadas no PTD }\end{array}$ & $\mathrm{X}$ & $\mathrm{X}$ & $\mathrm{X}$ & $\mathrm{X}$ \\
\hline $\begin{array}{l}\text { Manutenção de Açães } \\
\text { Implementadas }\end{array}$ & & & $\mathrm{X}$ & $\mathrm{X}$ \\
\hline
\end{tabular}

\section{Declaração da Proponente}

"Declaro ter conhecimento das disposiçōes contidas no MANUAL DE ORIENTAÇÃO AO PROPONENTE DE PRESTACÃO DE SERVIÇOS AMBIENTAIS no Âmbito do projeto Produtores de Água e Floresta e que as informaçōes aqui contidas são a expressōes da

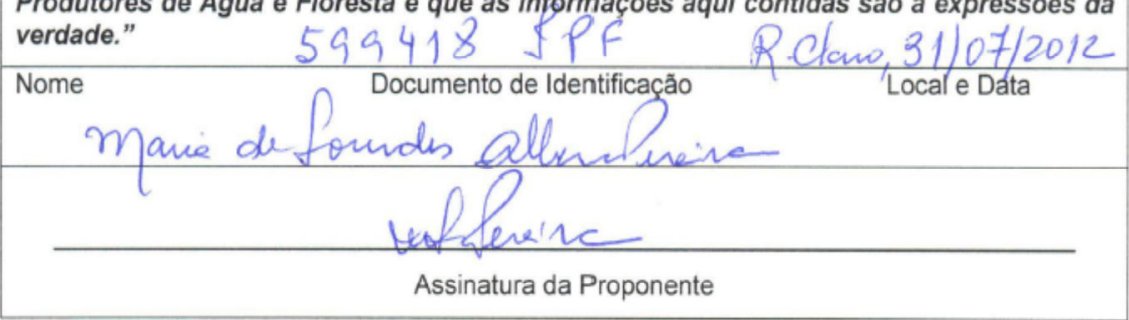

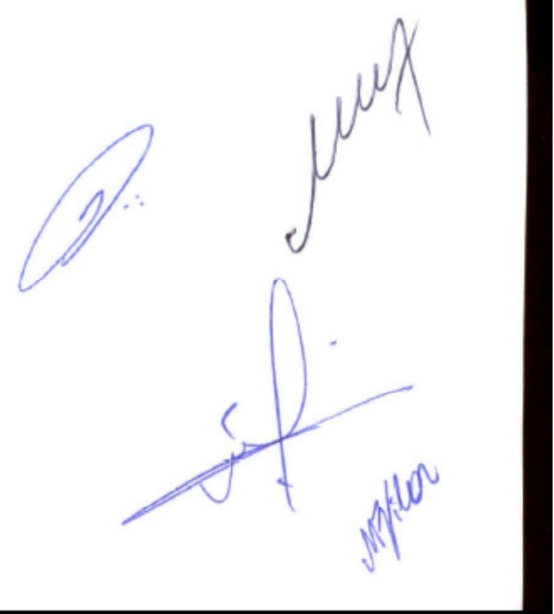



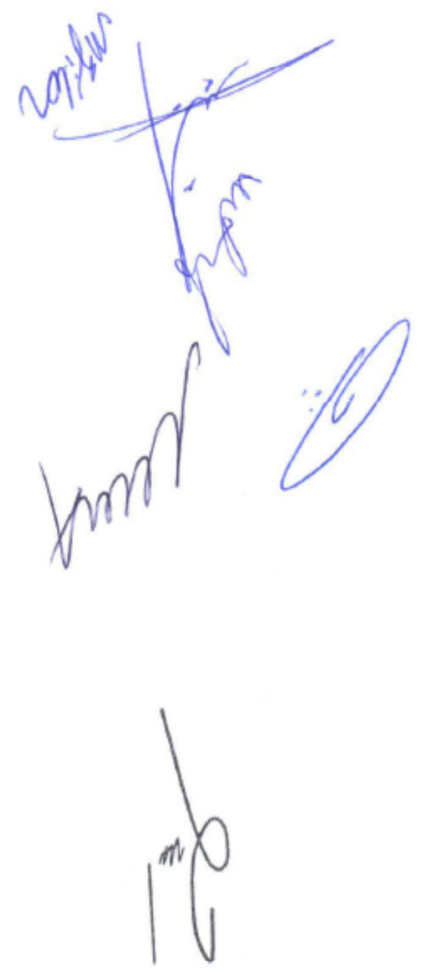

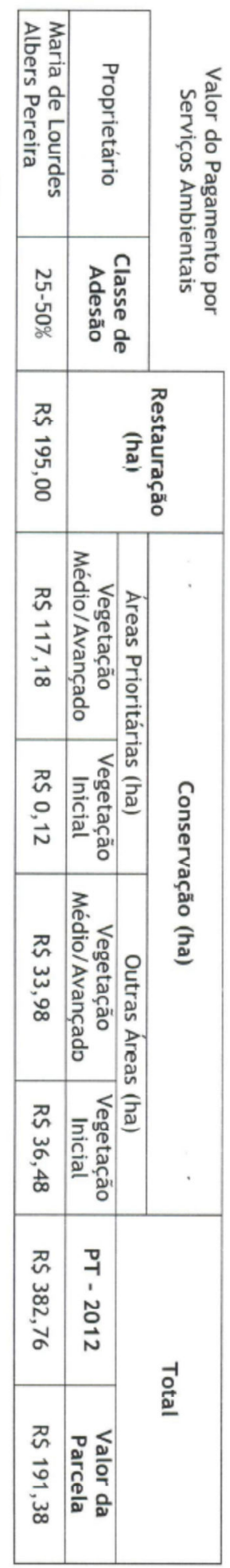

\begin{tabular}{|c|c|c|}
\hline 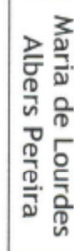 & $\begin{array}{l}\frac{0}{3} \\
\frac{0}{0} \\
\frac{0}{0} \\
\frac{0}{00} \\
\frac{a}{0}\end{array}$ & \\
\hline $\begin{array}{l}\vec{\omega} \\
\vec{\perp}\end{array}$ & 焉 & \\
\hline$\underset{\sim \sim}{\sim}$ & 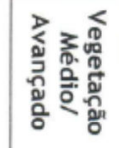 & \\
\hline$\ddot{8}$ & 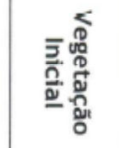 & B \\
\hline ò & 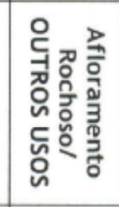 & . \\
\hline$\vec{v}$ & 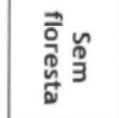 & \\
\hline $\overrightarrow{\vec{v}}$ & 总 & 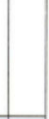 \\
\hline $\overrightarrow{ \pm}$ & 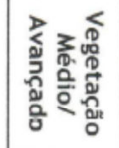 & \\
\hline $\overrightarrow{\mathrm{N}}$ & 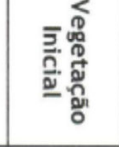 & 0 \\
\hline $\overrightarrow{\vec{A}}$ & 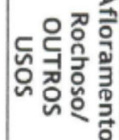 & 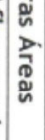 \\
\hline 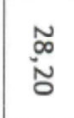 & 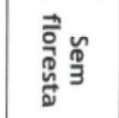 & \\
\hline $\begin{array}{l}\text { N } \\
\stackrel{N}{0} \\
\end{array}$ & 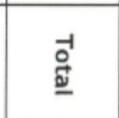 & \\
\hline
\end{tabular}

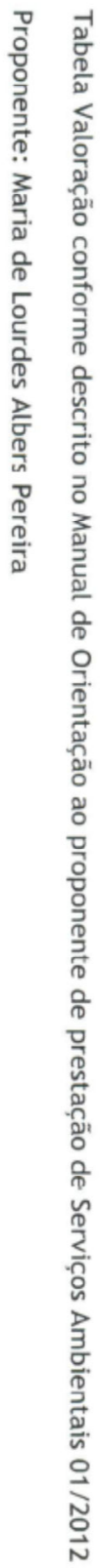




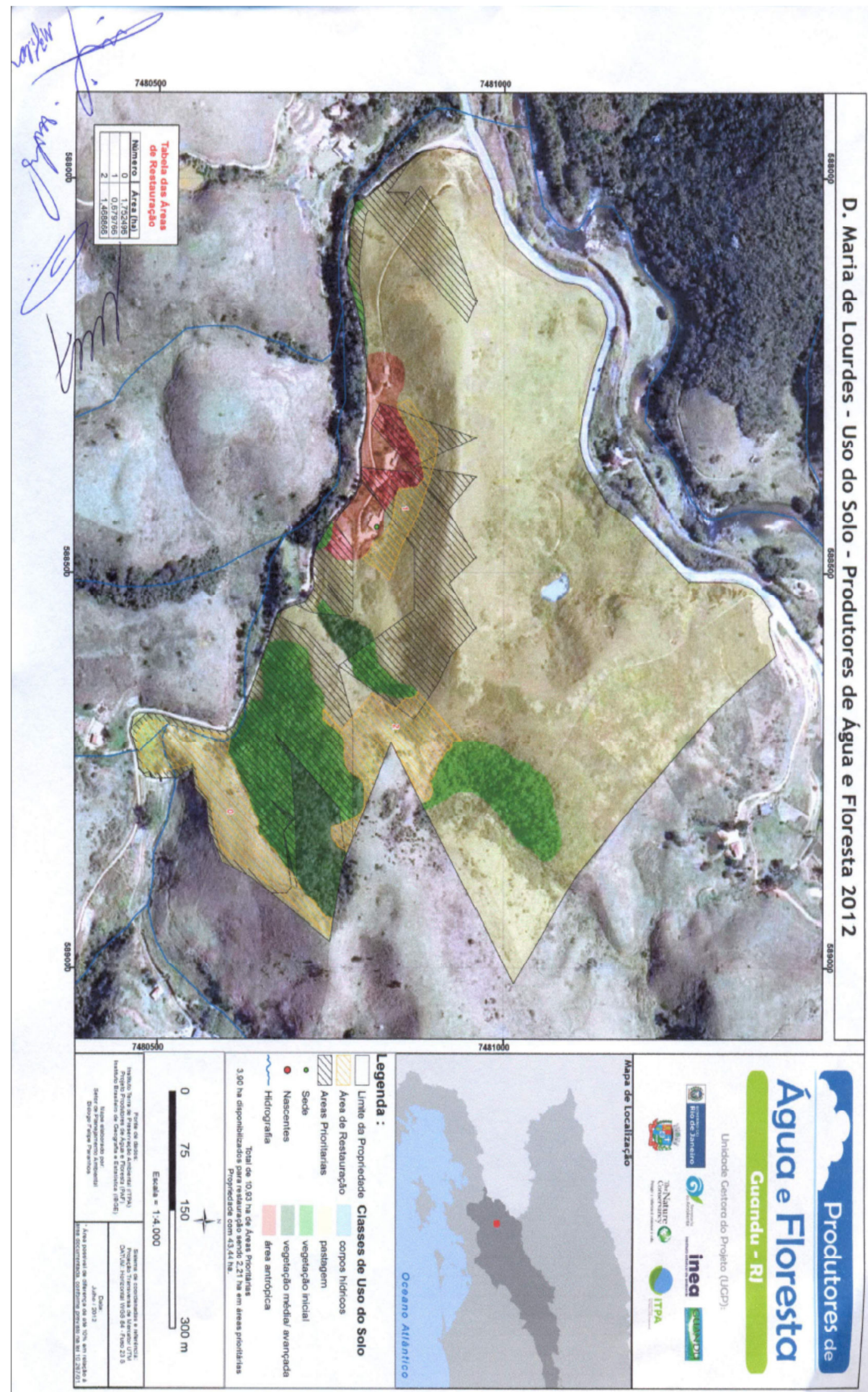

